\title{
G.R.I.P.S. COMMISSIÖN
}

2628 MENDOCINO AVENUE, SANTA ROSA, CÁLIFORNIA 95401 (707) 527-2025

FINAL REPORT

PEREGRINE FALCON STUDY

FEBRUARY 1,1980

Prepared Under Grant From

U.S. Department of Energy

Grant \#ET-78-6-03-2068

PORTIONS OF THTS REPORT PRE ILTEGIBTS

NOTICE

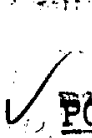
has been reprodued îrcm che best avali. copy to permit the broadest possible a ab111ty. 


\section{DISCLAIMER}

This report was prepared as an account of work sponsored by an agency of the United States Government. Neither the United States Government nor any agency Thereof, nor any of their employees, makes any warranty, express or implied, or assumes any legal liability or responsibility for the accuracy, completeness, or usefulness of any information, apparatus, product, or process disclosed, or represents that its use would not infringe privately owned rights. Reference herein to any specific commercial product, process, or service by trade name, trademark, manufacturer, or otherwise does not necessarily constitute or imply its endorsement, recommendation, or favoring by the United States Government or any agency thereof. The views and opinions of authors expressed herein do not necessarily state or reflect those of the United States Government or any agency thereof. 


\section{DISCLAIMER}

Portions of this document may be illegible in electronic image products. Images are produced from the best available original document. 



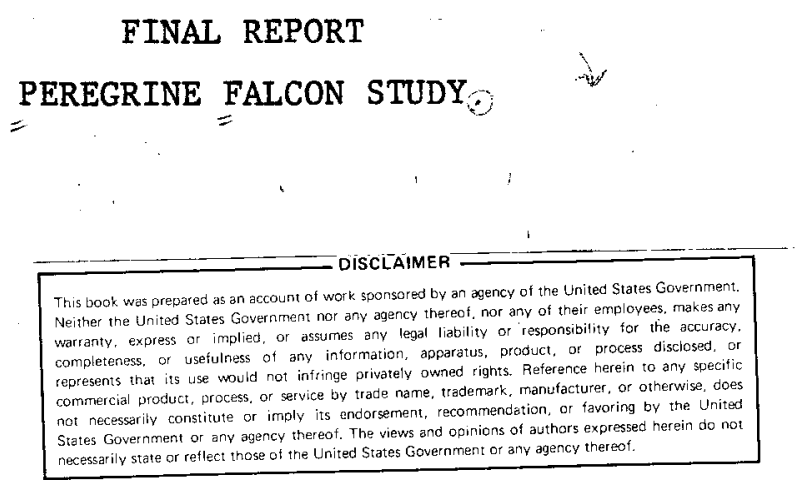

\author{
FEBRUARY 1, 1980 \\ Prepared Under Grant From \\ U.S. Department of Energy \\ Grant \#ET-78-6-03-2068
}


GRIPS Commission Members

Lake County

Mendocino County

Napa County

Sonoma County

California Energy

Commission

U.S. Department of Energy
Supervisor Ray Mostin, Chairman

Supervisor Walt Wilcox, Alternate

Supervisor James Eddie

Supervisor Norm deVa11, Alternate

Supervisor Dowell Martz

Supervisor Harold Moskowite, Alternate

Supervisor Nick Esposti, Vice Chairman Alternate - Vacant

Commissioner Suzanne Reed

Staff: Neil Moyer, David Hill

Regional Representative William Arntz

Staff: John Crawford

\section{GRIPS Peregrine Falcon Advisory Committee}

California State University at Sonoma

California Department of Fish and Game

United States Fish and Wildlife Service

United States Bureau of Land Ilanagement

\section{Project Contractors}

PHASE I: FIELD STUDIES

Contract Coordinator Project Contractor Field Observation Team
John Arnold

Alan Buckman and

Robert Mallette

David Harlow

Richard Olendorff
Tom Cordill, Sonoma County Planning Dept. Monte N. Kirven

Bryant Bainbridge

Timothy Bowles

Douglas Boyce

William Grummer

Steven Hoddy

Craig Thomsen

Thomas Scott

Richard Olendorff, Bureau of Land Management James H. Enderson Monte N. Kirven

$P$. Anderson

B. Braker

Robert F. Van Horn

Paula Blaydes

Sue Ellen Bolt

Dorothy A. Ross 
TABLE OF CONTENTS

Introduction to Project Reports.............. iv

$\checkmark$ PHASE I REPORT -1978 Visual Survey............. I-1

PHASE I APPENDIX A - 1977 Visual Survey........... I-AI

PHASE II FINAL REPORT - Peregrine Falcon Foraging Study $-1979 . \ldots \ldots \ldots \ldots \ldots \ldots \ldots \ldots \ldots \ldots \ldots \ldots \ldots$ II -1 
INTRODUCTION TO PROJECT REPORTS

The field studies on Peregrine Falcon foraging activities described herein were initiated to determine the possible impact of geothermal development on this endangered species. In 1977, Republic Geothermal, Inc. commissioned a field study by Monte $N$. Kirven, Sonoma State University, to provide information on the Peregrine Falcon eyrie which was located in close proximity to a proposed exploratory well site.

The information obtained in this field study (see I, Appendix A) was not considered sufficient for decision making by the Sonoma County Planning Department. Since the falcon eyrie is adjacent to the boundary between Lake and Sonoma Counties, and is close to Napa County, the Sonoma County Planning Department Staff felt that information generated in further study would be of interest and concern to the other counties. Tom Cordill, Sonoma County Planning Department, approached the G.R.I.P.S. Commission with a proposal that G.R.I.P.S. seek a grant from the Department of Energy to conduct a more detailed study of the foraging activities of the falcon and the potential impact of geothermal development on those activities.

In May, 1978, Mr. Cordill took the responsibility for developing the proposal and submitting it to the Regional office of the Department of Energy. The grant of $\$ 32,500$ was approved in May, 1978 , and organization of the project was initiated immediately thereaf ter.

Mr. Cordill brought together the Advisory Committee listed on Page ii. The group developed the program plan which called for: 
visual observation during the summer of 1978; the Phase I Report of that activity; the outline for the 1979 telemetry study; and, the projected schedule for all of these activities.

An abstract of the Phase I Field Study Report is provided on Page I-ii. The recommendations from that Study are included on Page I-48. The Phase I Report was presented by Dr. Kirven to the G.R.I.P.S. Commission at its November 9, 1978, Meeting. Subsequently, copies were forwarded to the Department of Energy Regional Office in San Francisco.

The Advisory Committee met in November of 1978 to review the first Draft of the Phase I Report and to develop the detailed Work Program for the telemetry study activities. As a follow-up to the decisions made at this meeting, the G.R.I.P.S. Commission made an agreement with the U.S. Bureau of Land Management for Richard R. Olendorff, BLM Sacramento staff nember, to coordinate the Phase II Telemetry study activities. In addition to the time devoted by Mr. Olendorff and his staff, the Bureau of Land Management contributed $\$ 7,500$ to the project.

The Telemetry element of the project was carried out during the spring and sumer of 1979 through a contract executed between the Bureau of Land Management and James H. Enderson, Colorado College. The abstract for the final report on that part of the project is provided on Page II-ii herein. The Management Recommendations for that report are incorporated on Page II-16 herein.

The Draft Final Report on the Telemetry Phase was distributed among the members of the Advisory Committee and other review sources in November, 1979. The Advisory Committee met for a final presentation on the report on January 17, 1980. On that date, Dr. Enderson made a presentation to the G.R.I.P.S. Commission at its regular meeting. 
In response to a request from the G.R.I.P.S. Commission at that Meeting, Dr. Enderson's contract with the Bureau of Land Management has been amended to provide for preparation of a semipopular media account which is due for completion by June 1, 1980 . 
vii

$\theta$

$\theta$ 


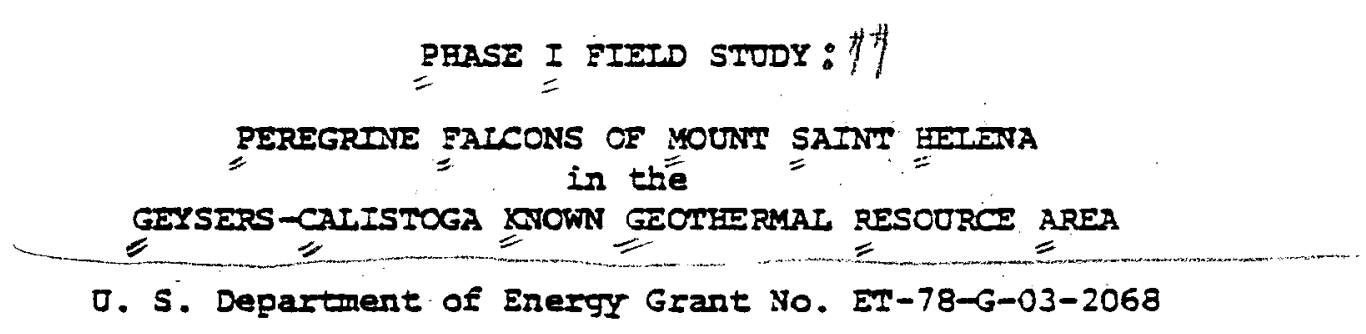

Submitted to
GEOTEERMAL RESOURCE INPACT PROECT STUDY JOINI POWERS AGENCY and
J. S. DEPARUMENT OF INERGY and
OTERR INTERESTED PARTIES

by

Monte N. Ristren

School of Enviromental stadies and planning 
The Phase I field study was conducted from 30 May to 20 August 1978 in an effort to monitor the foraging and breeding activities of a family: of endangered American Peregrine Falcons nesting in the vicinity of Mt. st. Belena, Sonoma County, California to determine, if possible, the :extent to which these birds utilize the adjacent known Geothermal Resource Area. Prominent local terrain featares and forest vegetation hampered. visual tracking of the falcons throughout the durations of their foraging Elights and 59.6 percent of all observed flights and 93.3 percent of all successful flights wera lost from view of the observers at the terminal. extensions. In spite of this inherent difficulty 65 map plots were recorded for foraging Elights within a 3.3 kilometer radius of the nesting site and two major flight corridors were identified along which 68 percent of all flights were oriented. The mean duration of successful slights of tie adult male was 68.3 minutes, which was substantially shorter than observed for peregrines nesting at the nearby Palisades eyrie in Napa County suggesting the possible superiority of the Mt. St. Helena foraging habitat. F ron prey remains found in the vicinity of the nesting site thirteen species were identified. Pigeons and doves comprised 67.3 percent of the total bionass, compared to 69.4 percent at the Palisades eyrie in 1975; -stressing the inportance of these birds as prey items. A total of 32 territorial defense. Flights were observed at the Mt. St. Eelena site in 1978 and Golden Eagles. appeared to elicit the most aggressive responses from the-falcors with a mean attack distance of 767 meters and a maximum of 2 kilometers observed. Red-tailed lawks were second in importance with a mean distance of 330 meters; and Turkey Vultures were relatively unimportant. Hunt observed similar-behavior for the Palisades Peregrines in 1976. Fuman intuders at both sites caused the breeding peregrines to become highly agitated and for this reason. strict protection of these sites is essential. Three young : fledged at Mt. St. Helena in 1978 with a mean fledging success rate of 2.8 observed for 5 years which represents high sucsess when compared to Peregrines in other reqions of North America. The post-fledging parental care period lasted. for at least two months and a yearling from 1977 appeared at the eyrie several times during the 1978 breeding season. Floral and faunal diversity in the study area was noteworthy with 218 species of plants, 77 species of birds, 38-species of manmals, 14 species of reptiles and 11 species of amphibians inventoried for at least seven biotic communities represented.: Such diversity provides a prey base which insures the continued zeproductive success

- of the falcons. Muman alteration of the habitat could threaten the long-... term survival of this endangered species as it has in Southera Califormia. where breeding Peregrines are now almost extinct. The foraging range and fate of fledglings at Mt. St. Helena could not be determined during: 1977 and 1978 in the absence of telemetry data. Therefore, the author emphatically zecommends that such data be gathered during the 1979 breeding season and every effort be made to expedite the phase II field study.- 
INTRODECIION

Historical Retrospect $\ldots \ldots \ldots \ldots \ldots \ldots \ldots \ldots \ldots \ldots \ldots \ldots \ldots \ldots \ldots$ I

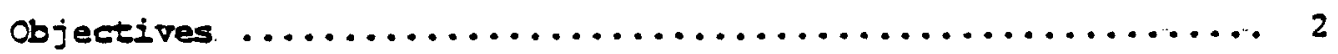

METHODS AND TYE STUDY AREA

The study area $\ldots \ldots \ldots \ldots \ldots \ldots \ldots \ldots \ldots \ldots \ldots \ldots \ldots \ldots$

The observational program $\ldots \ldots \ldots \ldots \ldots \ldots \ldots \ldots \ldots \ldots \ldots \ldots \ldots, 3$

Identification of Prey species $\ldots \ldots \ldots \ldots \ldots \ldots \ldots \ldots \ldots \ldots \ldots$

RESUITS AND DISCJSSION

Foraging Flights $\ldots \ldots \ldots \ldots \ldots \ldots \ldots \ldots \ldots \ldots \ldots \ldots \ldots \ldots$,

Prey $\ldots \ldots \ldots \ldots \ldots \ldots \ldots \ldots \ldots \ldots \ldots \ldots \ldots \ldots \ldots \ldots \ldots \ldots \ldots$

Territorial Defense Flights .................... 19

Breeding Cycle Chronology and Fledging success .......... 31

Floral and Faural Diversity in the study Area ........... 35

RECOMMNDATIONS $\ldots \ldots \ldots \ldots \ldots \ldots \ldots \ldots \ldots \ldots \ldots \ldots \ldots \ldots \ldots \ldots \ldots, 48$

IIMERATURE CITED ............................. 49

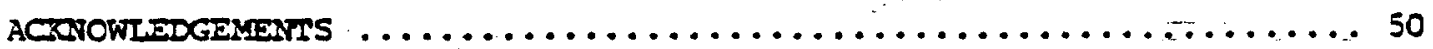
APPENDIX 
Figure 1. Map Plots of Observed Peregrine Falcon Foraging Flights

-Table 1 Foraging Flights of Adult Peregrine Falcons at: Mount Saint. Helena in 1978.

Table 2 Successful Foraging Flights of the Adult Male Peregrine Falcon at the Mount Saint Eelena Eyrie in 1978.

Table 3 Comparative Durations of Foraging Flights for Adult Male Peregrine Falcons During the Breeding Season.

Tabie 4 Directional Orientation of Foraging Flights from the Mount Saint Relena Peregrine Falcon Eyrie in 1978.

Table 5 Prey Species of Adult Peregrine Falcons Identified from Prey Remains at or near the Mount Saint Helena Eyrie in 1978.

Table 6

3ird Species Observed Fithin the Persgrine Falcon Foraging Habitat at Mount Saint Helena in 1978.

Table 7 Territorial Defense Flights of Adalt Peregrine Ealcons at: the Mount Saint Eelena Eyrie in 1978.

Table 8 The Chronology of the Peregrine Falcon Breeding Cycle in the known Geothermal Resources Area.

Table 9 Fledging Success of Peregrine Falcons Nesting in the Rnown Geothermal Resources Area.

Table 10 Plant Species in the Peregrine Falcon Foraging Fabitat at.. Mount Saint Helena in 1978.

Pable 11 Mammals in the study Area

Table 12 Reptiles in the Study Area 


\section{INTRODUCTION}

\section{Eistorical Retrospect}

Peregrine Falcons have been known to nest in the imediate vicinity of Mount Saint Helena from 1970 Enrough 1973 (Wenzel and Gheen 1975), and probably during the preceeding years in the characteristic manner of the species (Earlow, personal communications). The area was unoccupied by breeding birds from 1974 through 1976, and it was feared that the tragic pattern of reproductive failure, which has been well-documented throughout most of the species range in North America (see Appendix), was being repeated at this site. In 1977 , however, a pair of breeding Peregrines appeared late in the season and Eledged three young. Because the site is located in close proximity to proposed geothermal exploratory drilling sites nuch local interest was aroused. Concern was expressed about the potential threat of such develooment to the long-term surrival of these endangered falcons by members of the California Departnent of $\mathrm{Fish}$ and Game, U. S. Department of Interior Fish and Wildifie Service and Bureau of Land Managenent, Sonoma County Planning Department, Califomia State Parks, faculty of Sonoma state University and other local colleges, and ornithological and conservation groups; as well as concerned citizenry. During the same year, in response to these concerns, Republic Geothermal, Incorporated assumed the financial responsibility of contracting the author to initiate a study to monitor the foraging and breeding activities of the Ealcons in an attempt to assess the potential impact of drilling operations which Republic was planning to undertake in the Briggs Creek drainage of their leaserold on the MeMicking Ranch, which includes the descending foothilis west of the Peregrise nesting site.

The results of the 1977 field study were deersd inconclusive by the 
author, but much usefur information was gathered anc a sopy of the geport submitted to Republic Geothermal, Inc, and other interested parties has. been included in the Appendix to be used as a companion document;. The author recommended that a more torough stady employing zadio-telemetzic, as well as visual, monitoring techoiques be undertaken as soon as possible. In subseguent meetings of zepresentatives from the U.S. Fish and Wildiffe Service; Bureau of Land Management, California Deparsnent of Iish and Game, Sonoma County Placoing Depar=ent, Republic Geotheral, Inc. and the academie commonify, it was unanimousiy eoreluded that such a study be pursued wit rigor. A comitese of experts on faleon biology and radio-telemeery. was appointed for furher diseussions and proposals.

Early in 1978 a researej proposal was submitsed by the Sonoma County. Planoing Degarment trough the G.R.I.P.S. Joint Powers AgenCl to tre U.S. Depar ent of Energy, which awarded Grant No. Ex-78-G-03-2068 in support. of the proposed researeh on May 8, 1978. The Phase I Eiele study was commenced at the end of May uncer the direction of the author and the findings comprise this report.

\section{Objectives}

The Phase I field swidy was undertaken to conduct visual eracking of ... the pair of adult Peregrine Falcons nesting at ut. St. Helena and record di-ection, distance, Erequency, and duration of flight pattars which wight be in, over or through contiguous geotieral areas; to: collect and analyze prey remains around the resting site and inventory adjacent habitats occupied by potential prey species. 
MEHAODS AND THE STUDY AREA

The Stady Area

In 1978 the falcons nested in precisely the same location as they did during the previous year, therefore the description of the major topographic and regetative features of the area in the immediate vicinity of the eyrie incladed in the 1977 report remains applicable (see Appendix). In addition to those general remarks, the biotic diversity of the foraging area of the falcons was considered by the author to be sufficiently notewortiby to warrant more thorough investigation during the 1978 phase I fieli study. A botanical inventory, conducted in the watershed to 5.5 kilometers south of the eyrie cliff, reflected the rich diversity of the area. The plant comunities represented within the study area include Douglas-fir Forest, Mixed Evergreen Forest, Oak Woodland, Riparian Noodland, Chaparral, Grassland and Ereshwater Marsh. A list of 218 plant species was compiled by Craig Thomsen for the study area (see Results and Discussion). It was anticipated that such an extensive and diverse vegetation complex and species rich flora would support a large and abundant avifauna which would constitute a potential prey base for the Peregrines. A bird census was conducted in the same watershed and over the ridge runsing southwest from the eyrie cliff and along the western side of the canyon to a distance of 1.7 kilometers. Seventy-seven bird species were observed in the stuch area by Bryant Bainbridge and other members of the observation tean (see Results and Discussion). Additional faunal lists of mamals, reptiles and amphibians were compiled by the author and included in this report to furtier demonstrate the biotic diversity of the strdy area (see Resalts and Discussion).

The Observation ?rogram

The Phase I Eield work commenced on 30 May 1978 and terminated on 
20 iugust of the same gear. Duzing the period of 30 May so- $13 \mathrm{July,}$ däy-long observations were nade on the activities and directional movements of the Ealcons from two vantage poines in the vicinity of the eyrie. These-sites, which will be referred to as Obserration Posts $1 O R$ I and 2 , wero-located southeast of the eyrie at distances of 350 meters $(091)$ and 760 -meters $(O P 2)$. The elevation of OPI was just below the level of the nesting ledoge and $O P 2$ was just above it. The obserration team consisted of Timoriy Bowles, Steven Hoddy, Brpant Bainbridge, Douglas Boyce and Craig Thomsen. Bowles and lodidy, who were nost Smiliar with the sita, conducred the majority of the observations duriag the Sield study, and were relieved at intervals by the other umbers of the team. ...ptior to the initiation of the ghase I field observation program, surveillarce persorsel representing the U.S. Deparenent of Interior, Iish and Wildiffe Serrice, Pacific Coast Zeregrine galeon Recovery Team Psogram vere: on 24. hour dut? at OR2-szom just prier to egg-laying (7 March) antil 1 Jure. Thomas Scote was responsible for surpillance during weekdays anc on: weekerds he was relieved dy State Zark kanger Nilliam Grinmer. They also. recorded theil obserrations on the falcons and some of their data has been incluced in this report. Observational data from other surgeillance gersonsel (Werzel. and Gineen 1975, Eunt 1976) at another peregrine Falcon eyzie located 3 kilameters to the southeast have also been incorporated into this report Sor comparative surposes. On $19 \mathrm{july}$ the author, nembers of the observation

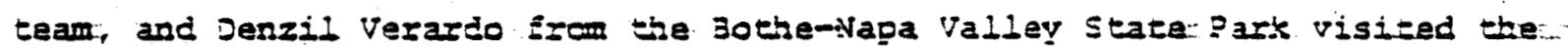

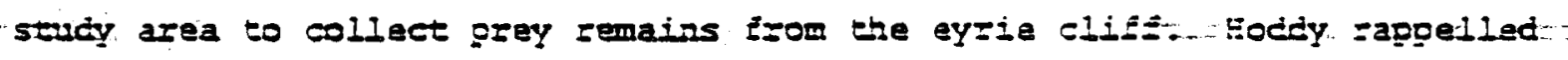
to-the nesting ledge and verardo grovided the belay aid, while the remainder

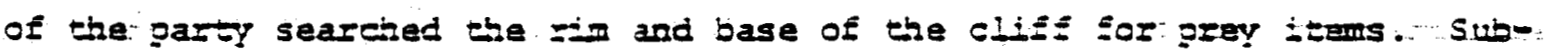
seguent visits wers made to the top of the elikf on 26 July and 20 August 
by the author to determine the duration of occupancy of the site by the Ealcons.

with the exception of the following, the observational techriques and equipment were the same as those employed is 1977 and will not be repeated here (see Appendix). Ifforts to plot t=iangulations on the map were abandoned because it was almost impossible for observers at the two observation posts to simultaniously plot the location of a falcon at the teminal extension of the flight path due to visual obstacles in the mountainous landscape. Instead, compass bearings and flight directions were recorded by one observer who would consult the other observer on the radio when necessary. By familiarizing themselves with prominent local terrain features, the abservers were able to estinate approximate distances of the falcons along the compass bearisgs and flight direction.

The observed activities and movenents of the falcons were subdivided by the author from the field notes into the following categories:

1. Breeding behavior, including courtship, copulation, cluteh formation, incubation and all other behavior associated with the chronological events of the reproductive cycle. Irom these data the timing of the reproductive chronology was extrapolated (Fable 8).

2. Foraging flights, including departure tines and directions, maximum obserred distances (Figure 1 ), times and directions of return Elights, success or failure in obtaining prey, and food exchanges at or near the eyrie (Table 1 ).

3. Territorial defense attacks on intruders in the vicinity of the eyrie, including the species involved and discriptions of the flights (Table 7).

4. Flights which did not appear to result in any of the above categories such as movements from perch to perch, soaring without departure, apparent exercise and play. These data were irrelevant to the objectives of the stucy, and were omitted fzom this zeport. 
Identification of prey soecies

The remains of grey items collected on $19 \mathrm{July}$ wera taken to the

onnitiological collection of the Califormia lcademy of sciences in

San Francisco for cemparison witb intact study skins and skeletons.

- Species icentification was accomplisined for all but a single i tem by the author and Brgant Bainbridge. 


\section{Eoraging Elights}

The mountainous terrain and forest vegetation in the stucy area hampered visual tracking of foraging flights again in 1978. However, it was possible to monitor the movements of the falcons to some extent and 65 map plots were recorded for visual sightings (Figure 1). Eaci plot represents the position of the falcon at the teminal extent of the Elight or the point at which it was last seen by the observer. The sex of the Ealcon and the approximate direction of the flight path were also recorded for each observed foraging flight. Numerical designations for the plots represent the chronological occurrence of sightings and can be cross-referenced to additional information in Table 1 . From these data it can be seen that in the majority of cases the terminal extensions of the soraging flights were lost from the view of the observers. This occurred when the falcons flew behind orominent terrain features, blended with the forest background or passed beyond the limit of visibility for the $20 x$ spotsing seopes. of all the flights observed 56.9 percent were lost from view (Table l) and 93.3 percent of successful flights were also lost (Table 2). The higher proportion of lost flights in the latter categorl suggests that successful foraging Elights extenced to greater distances on the average than unsuccessful forays. Only the foraging flights of the adulimale were considered in this study, in terns of success, because of the traditional role of males of this species to provice most of the food during the breeding frcle, and the possibility that the female received prey in a focd exchange out of view of the observers before returning from a flight. The mean duration of successful foraging flights was observed to be 68.3 minutes (Table 2) compared to a mean of 27.3 minutes $(n=9)$ for unsuccessful slights. This 
Figure I Map Plots of observed Peregrine Falcon EoragingZlights in 1978.

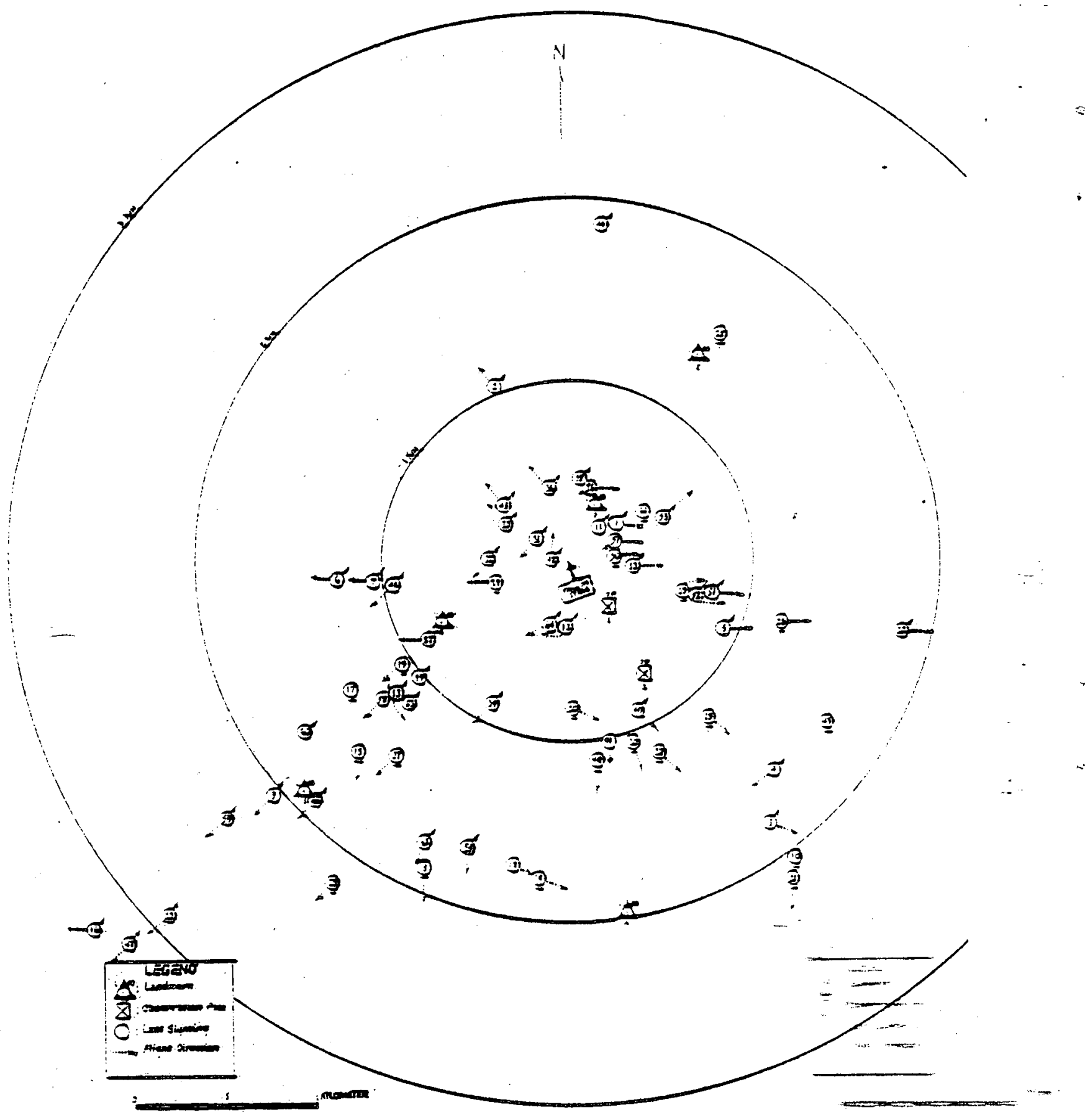


Table 1 Eoraging Flights of Adult Eeregrine Falcons at Mt. St. Helena in 1978.

\begin{tabular}{|c|c|c|c|c|c|c|c|}
\hline $\begin{array}{l}\text { Map Plot } \\
\text { Number }\end{array}$ & Date & Sex & $\begin{array}{l}\text { Time } \\
\text { Out }\end{array}$ & $\begin{array}{c}\text { Time } \\
\text { In }\end{array}$ & Observed Eliaht Path & mpass & $O P \#$ \\
\hline 1 & $5 / 30$ & M & 1400 & hrs & Lost heading $\mathrm{E}$ from eyrie & $9^{\circ}$ & 1 \\
\hline 2 & " & $"$ & 1615 & 1710 & Lost heading sw from eyrie & $334^{\circ}$ & 2 \\
\hline 3 & $"$ & $"$ & 1710 & 1724 & Lost $\Xi$ of Landeark (LM) A & $241^{\circ}$ & 2 \\
\hline 4 & $"$ & $"$ & 1746 & - & Pursuing prey toward In $A$ & $132^{\circ}$ & 2 \\
\hline 5 & $5 / 31$ & $"$ & 1012 & 1117 & Lost heading $\equiv$ from above $O P 1$ & $50^{\circ}$ & 2 \\
\hline 6 & $"$ & $"$ & 1620 & - & Lost heading $w$ from eyrie & $288^{\circ}$ & 2 \\
\hline 7 & $6 / 3$ & $"$ & 1530 & - & Iost heading $w$ from eyrie & $290^{\circ}$ & 2 \\
\hline 8 & $6 / 4$ & $\boldsymbol{F}$ & 1457 & 1504 & $\begin{array}{l}\text { Stooped at pigeon heading } S \\
\text { from IM } C\end{array}$ & $215^{\circ}$ & 1 \\
\hline 9 & $1 "$ & $\mathrm{M}$ & 1600 & - & Lost diving sw from in $C$ & $251^{\circ}$ & 2 \\
\hline 10 & $"$ & $\boldsymbol{F}$ & 1612 & - & Lost Elying high $\mathrm{E}$ of IX $\mathrm{A}$ & $144^{\circ}$ & 2 \\
\hline 11 & $6 / 5$ & $M$ & 1201 & 1202 & Stooped at swift $\sqrt{E}$ of eyzie & $358^{\circ}$ & 1 \\
\hline 12 & $1 "$ & " & 1231 & 1240 & Toward Ly $C$ from eyrie & $248^{\circ}$ & 1 \\
\hline 13 & $"$ & $M$ & 1430 & 1630 & From IM $C$ to IM A & $248^{\circ}$ & 1 \\
\hline 14 & $"$ & $\boldsymbol{F}$ & 1510 & 1515 & $\begin{array}{l}S \text { Erom eyrie, accelerated } \\
\text { to IM A }\end{array}$ & $194^{\circ}$ & 1 \\
\hline 15 & $6 / 6$ & $"$ & 1240 & 1530 & $\begin{array}{l}\text { Lost heading } S \text { from above } \\
\text { LM } B\end{array}$ & $240^{\circ}$ & 1 \\
\hline 16 & $"$ & $M$ & 1310 & 1605 & SW from eyrie, lost heading $w$ & $238^{\circ}$ & 1 \\
\hline 17 & $"$ & $\Sigma$ & 1530 & 1605 & $\begin{array}{l}\text { Stooped at prey near LM } C \\
\text { heading } S\end{array}$ & $268^{\circ}$ & 2 \\
\hline 18 & $"$ & $?$ & 1612 & 1630 & Toward LM A from S of eyzie & $215^{\circ}$ & 2 \\
\hline 19 & $"$ & $\vec{F}$ & 1630 & - & $\begin{array}{l}\text { sw fzom LM C, zetursed to } \\
\text { eyrie }\end{array}$ & $255^{\circ}$ & 1 \\
\hline 20 & $6 / 7$ & $\Xi$ & 1645 & - & $\begin{array}{l}\text { Stooped SE Erom high above } \\
\text { IN } C\end{array}$ & $245^{\circ}$ & 2 \\
\hline
\end{tabular}


Sable 1 - Contirued/




Table 1 -- Continued/

\begin{tabular}{|c|c|c|c|c|c|c|c|}
\hline $\begin{array}{l}\text { Map Plot } \\
\text { Number }\end{array}$ & Date & Sex & $\begin{array}{l}\text { Time } \\
\text { Out }\end{array}$ & $\begin{array}{l}\text { Tine } \\
\text { In }\end{array}$ & Obserred Flight Path & $\begin{array}{l}\text { ompass } \\
\text { earing }\end{array}$ & $\mathrm{OP} \#$ \\
\hline 39 & $6 / 17$ & F & 0940 & 1055 & $\begin{array}{l}\text { Lost in rapid pursuit } \\
\text { heading } E \text { from eyrie }\end{array}$ & $78^{\circ}$ & 1 \\
\hline 40 & $"$ & $M$ & 1600 & 1615 & $\begin{array}{l}\text { Pursued swift anc continued } \\
\text { heading } \mathrm{SE}\end{array}$ & $165^{\circ}$ & 1 \\
\hline 41 & $6 / 18$ & $?$ & 1610 & 一 & Reading from $O R 1$ & $180^{\circ}$ & 1 \\
\hline 42 & $"$ & $M$ & 1640 & - & $\begin{array}{l}\text { Lost heading } \mathrm{N} \text { over eyrie } \\
\text { cliff }\end{array}$ & $315^{\circ}$ & 1 \\
\hline 43 & $"$ & $"$ & 1755 & - & $\begin{array}{l}\text { Lost soaring toward NW Erom } \\
\text { above eyrie cliff }\end{array}$ & $316^{\circ}$ & 1 \\
\hline 44 & $6 / 20$ & $"$ & 1020 & 1045 & $\begin{array}{l}\text { Long stoop at prey from iww } \\
\text { of IM E }\end{array}$ & $355^{\circ}$ & 2 \\
\hline 45 & $"$ & E & 1120 & 1130 & Stooped at prey ESE Erom OP2 & $105^{\circ}$ & 2 \\
\hline 46 & $"$ & M & 1355 & - & Lost soaring si from in $C$ & $277^{\circ}$ & 1 \\
\hline 47 & $6 / 21$ & $"$ & 1100 & 1131 & $\begin{array}{l}\text { Stooped at prey heading sw } \\
\text { from iM } 9\end{array}$ & $243^{\circ}$ & 2 \\
\hline 48 & $"$ & E & 1255 & - & $\begin{array}{l}\text { Heading } S \text { in rapid pursuit } \\
\text { from above OPI }\end{array}$ & $184^{\circ}$ & 1 \\
\hline 49 & $"$ & $M$ & 1710 & 1800 & Lost in stoop near iM $C$ & $251^{\circ}$ & 1 \\
\hline 50 & $5 / 22$ & $F$ & 0912 & 0920 & $\begin{array}{l}\text { Stooped } E \text { of eyzie and contin } \\
\text { ued heading } E\end{array}$ & $8^{\circ}$ & 1 \\
\hline 51 & $6 / 24$ & $M$ & 1535 & 1737 & $\begin{array}{l}\text { Lost heading } \equiv \text { from eyrie at } \\
\text { high speed }\end{array}$ & $82^{\circ}$ & 1 \\
\hline 52 & $"$ & $"$ & 1535 & 1737 & $\begin{array}{l}\text { Lost heading } \mathrm{E} \text { from eyrie at } \\
\text { high speed }\end{array}$ & $82^{\circ}$ & 1 \\
\hline 53 & $6 / 25$ & $"$ & 0846 & 0855 & $\begin{array}{l}\text { Lost heading NE Srom eyrie at } \\
\text { high speed }\end{array}$ & $26^{\circ}$ & 1 \\
\hline 54 & $6 / 26$ & $"$ & 0815 & 0920 & $\begin{array}{l}\text { Lost heading } S \text { between IM A } \\
\text { and IM B }\end{array}$ & $210^{\circ}$ & 1 \\
\hline 55 & $"$ & $"$ & 1028 & - & $\begin{array}{l}\text { Heading to LM D from acove } \\
\text { ORI }\end{array}$ & $349^{\circ}$ & 1 \\
\hline
\end{tabular}


Table 1 -- Continued/

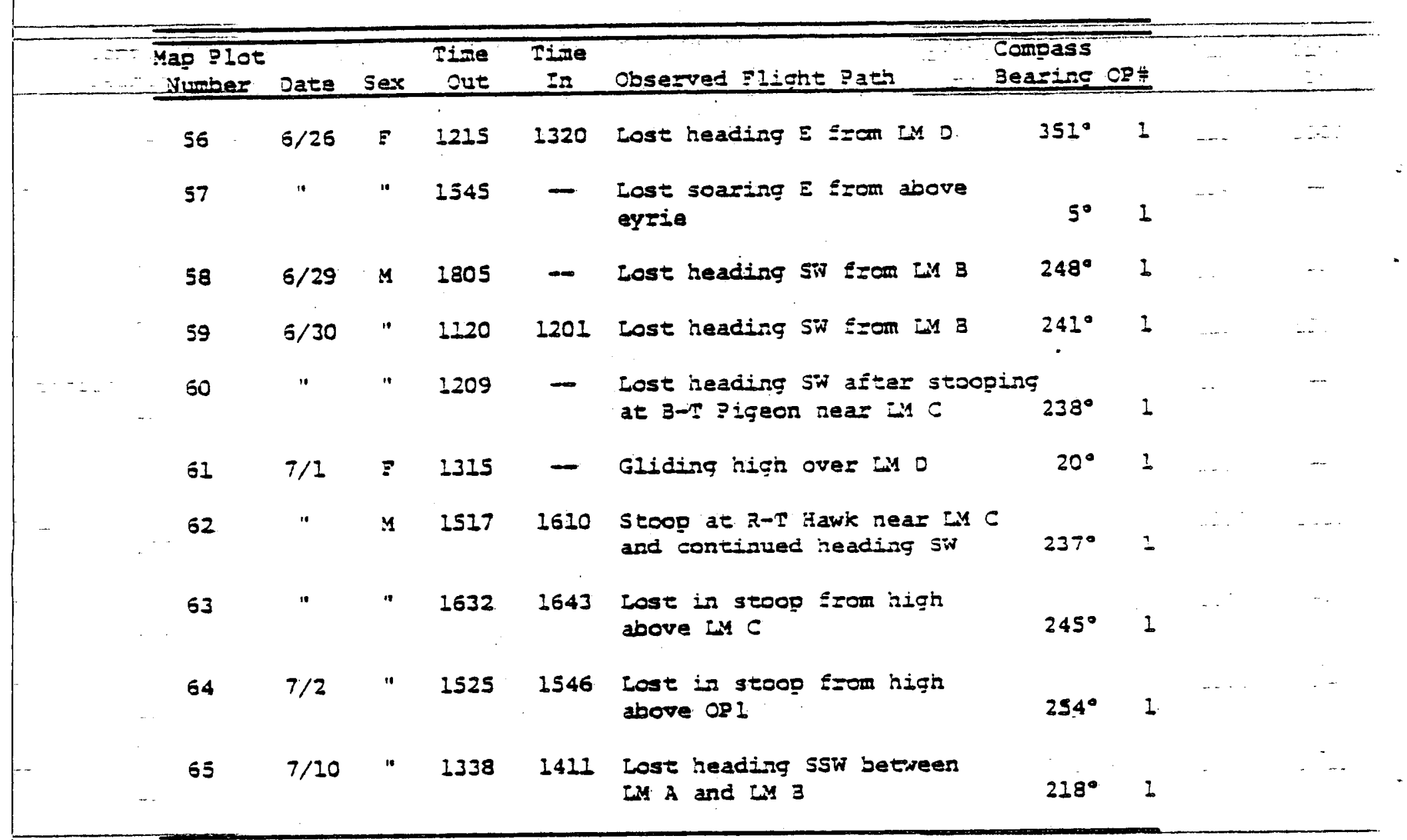


Table 2 Successful Foraging Flights of the Adult Male Perecrine Faicon at the Mount Saint Jelena Eyrie in 1978.

\begin{tabular}{|c|c|c|c|c|c|c|}
\hline Dace & $\begin{array}{l}\text { Time } \\
\text { Out } \\
\end{array}$ & $\begin{array}{l}\text { Tine } \\
\text { In }\end{array}$ & $\begin{array}{r}\text { Total } \\
\text { Time } \\
\text { (mis) } \\
\end{array}$ & $\begin{array}{c}\text { Observed Departure } \\
\text { Flight Path }\end{array}$ & $\begin{array}{c}\text { Observed Return } \\
\text { Flight Path }\end{array}$ & $\begin{array}{c}\text { Food } \\
\text { Exchange } \\
\text { Observed }\end{array}$ \\
\hline $5 / 8$ & 0859 & 0944 & 45 & $\begin{array}{l}\text { Lost heading SE froln } \\
\text { OP2 }\end{array}$ & Erom SW of OP 2 & + \\
\hline$"$ & 1645 & 1950 & 185 & $\begin{array}{l}\text { Lost heading SW from } \\
\text { LM } C\end{array}$ & Erom NE of OP2 & + \\
\hline $5 / 9$ & 0802 & 0847 & 45 & Lost heading $\sqrt{ }$ from & $F=0 m$ ve of OP 2 & + \\
\hline $5 / 13$ & 0902 & 1007 & 65 & $\begin{array}{l}\text { Lost heading i near } \\
\text { LM C }\end{array}$ & $\begin{array}{l}\text { At eyrie, direction } \\
\text { unknown }\end{array}$ & on \\
\hline $5 / 16$ & 0629 & 0728 & 59 & $\begin{array}{l}\text { Lost heading SW Erom } \\
\text { LM C }\end{array}$ & Erom NE of OR 2 & + \\
\hline$"$ & 1436 & 1528 & 52 & $\begin{array}{l}\text { Lost heading } \mathrm{E} \text { Erom } \\
\text { eyrie. }\end{array}$ & Erom $\Sigma$ of eyrie & + \\
\hline $5 / 20$ & 1130 & 1227 & 57 & $\begin{array}{l}\text { Lost heading } \sqrt{E} \text { Exom } \\
\text { eyrie }\end{array}$ & $\begin{array}{l}\text { At eyrie, direction } \\
\text { unknown }\end{array}$ & on \\
\hline $5 / 22$ & 1249 & 1326 & 37 & $\begin{array}{l}\text { Lost heading SW Ercm } \\
\text { IM } B\end{array}$ & $\begin{array}{l}\text { At eyrie, directior } \\
\text { unknown }\end{array}$ & on \\
\hline$"$ & 1610 & 1948 & 218 & $\begin{array}{l}\text { Lost heading } N \text { Erom: } \\
\text { LM C }\end{array}$ & Erom $N E$ of $O P 2$ & + \\
\hline $5 / 23$ & 1102 & 1209 & 67 & $\begin{array}{l}\text { Lost heading } \sqrt{E} \text { frem } \\
\text { OP } 2\end{array}$ & Erom $S E$ of $O P 2$ & + \\
\hline $5 / 24$ & 1617 & 1710 & 53 & $\begin{array}{l}\text { Lost heading } 5 w \text { frem } \\
\text { eyrie }\end{array}$ & Exom $5 ?$ & + \\
\hline $5 / 27$ & 0724 & 0822 & 58 & $\begin{array}{l}\text { Lost heading } \mathrm{I} \text { from } \\
\text { eyrie }\end{array}$ & Erom $E$ of eyrie & + \\
\hline $5 / 28$ & 1055 & 1152 & 57 & $\begin{array}{l}\text { Lost heading } E \text { Erain } \\
\text { LM D }\end{array}$ & $5=0 \mathrm{~m}$ : $\sqrt{E}$ of $O P 2$ & + \\
\hline $5 / 29$ & 1637 & 1741 & 64 & $\begin{array}{l}\text { Lost heading SE from } \\
\text { OP2 }\end{array}$ & Exom SE of CP2 & + \\
\hline $5 / 31$ & 1012 & 1117 & 65 & $\begin{array}{l}\text { Lost heading } \mathrm{I} \text { from } \\
\text { eyrie }\end{array}$ & From $\equiv$ of $C P 2$ & + \\
\hline
\end{tabular}


Table 2 - Contirued

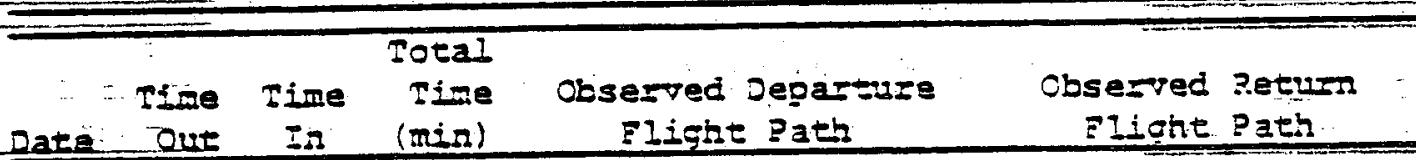

$\begin{array}{llll}6 / 5 & 1201 & 1231 & 30\end{array}$

" $14301630 \quad 120 \quad$ Exon LY C' to IV A

$6 / 6 \quad 1310 \quad 1605 \quad 175$

Lost heaciog in For. $\mathrm{SW}$ of Lu $\mathrm{I}$

$6 / 3 \quad 1028 \quad 2030$

2

Stooped at prey SE of OPZ

$1030 \quad 1140 \quad 70 \quad$ Lost headirg $E$ Ex eyrie.

$6 / 131220120941 \quad \begin{aligned} & \text { Lost heading Sw ETom } \\ & \text { eyril }\end{aligned}$

6/15 1553. 1702

69

Lost heading : Nh over eycie eliff

$6 / 20 \quad 1020 \quad 1045$

25

Lost heading $\equiv$ Erom EM $D$

$6 / 21 \quad 1100 \quad 1131$

.." $\quad 17101900 \quad 90$ Lost is stoop ș. of

.." $\quad 17101900 \quad 90$ Lost is stoop ș. of

31

Lost in stoop $W$ Exom

Ex $C$ Ix $C$

$6 / 24 \quad 1535 \quad 1737 \quad 122$

$6 / 30 \quad 1120 \quad 1201$

41

Lost heading $\mathrm{NE}$ Eron

$-7 / 1 \quad 1517 \quad 1610$

21 Lost in stoop headiso eyrie

lost headigg SW of ey $\mathrm{B}$

Lost in stoog SW of Ex 3 $W$ of ORI

Eliont Path.

$z=0 m$ it of eyzie

Esom SE (IM A) of. OP 1

Exon $\mathrm{H}$ of eyzie

Ezom $S E$ of eyrie

At eyrie, disection 0 unknown

At eyzie, difection + unksown

Exore ST of OP2

Ifom $E$ of ey=ie

0

Erom $N$ of eyrie

0

At errie, difsction t unkrown

At eysie, direction 0 univarow

Ex in of eyzio

it eyrie, direction uskersow

it eyzie, difection. unkeown

Lost headirg SSW Ezom ETom LW A 0 INC 
observation tends to support the conclusion that successful foraging Elights covered greater distances than unsuccessful foraging Elights. The slightly longer mean duration of foraging flights (77.3 minutes) of the adult male in 1977 (Table 3) could be the result of a greater familiarity with the area, if it can be assumed that he arrived on the scene after the period of inactivity of the nesting site. However, other iactors such as differential availability and abundance of prey curing the two breeding seasons nust also be considered. Then compared to the mean foraging flight duration of the male Peregrine at the nearby Palisades eyrie (Table 3) it can be seen that the Mt. St. Pelena male apparenty requized less time to obtain Eood. Eunt (1976) has sugcested that duration of foraging flights can be used as an incex of habitat guality. If this is a valid assumption, then the foraging habilat utilized by the Mt. St. Helena falcons must be considered to be superior. The comparatively shorter mean duration of foraging flights observed by white (1974) in Alaska could be due to the fact that the tundra habitat is zelatively devoid of cover for evasive maneuvers of prey species.

The exact size of the foraging area cannot: be determined From the data now available because most of the foraging slights were not obserred throughout their durations. The majority of Elights ( 87.7 percent), however, were tracked to within 2 kilometers of the eyrie and the remainder $(12.3$ percent) were between 2 and 3.3 kilometers. From these plots it can be seen that two main flight corridors were used in 1978 which followed certain terrain Eeatures (Figure 1) . Perhaps the most important corritor consisted of the watershed canyon which fans out from near the base of the eyrie clifi and descends to the southwest with fidges funning southwest and solithsoutheast. The canyon lies between landmark $C$ and obsertation Post 2 at 
Table 3 Comparative Dorations of Eoraging Flights For scult Male Reregrine Ealcons During the Breeding Season.

\begin{tabular}{|c|c|c|c|c|c|c|}
\hline & Autso=: $=1$ & Year & $\begin{array}{c}\text { Hean Elighe } \\
\text { Tine }(m i-)\end{array}$ & $\begin{array}{l}\text { Rarge } \\
\text { (min) } \\
\end{array}$ & 5 & Locaeion of Ev=ie \\
\hline$\cdots$ & ienzel and Gheen & 1975 & 106 & $18-290$ & 25 & $\begin{array}{l}\text { Palisacies., Iapoa } \\
\text { Countr, CaliEónia }\end{array}$ \\
\hline$\cdots$ & تีน & 1976 & 81.5 & $8-157$ & 53 & $\begin{array}{l}\text { Palisades, Yaga } \\
\text { Count?, Califoria }\end{array}$ \\
\hline$\cdots \cdots$ & $\begin{array}{r}\text { Kirren } \\
\cdots\end{array}$ & 1977 & 77.3 & $3-169$ & 37 & $\begin{array}{l}\text { Mt. st. Felena, } \\
\text { Sonoma Cty., CaliE. }\end{array}$ \\
\hline & xizten & 1978 & 68.3 & $2-218$ & 29 & $\begin{array}{l}\text { Mt. st: Eelena, } \\
\text { Sonoma Cty., Calij.. }\end{array}$ \\
\hline 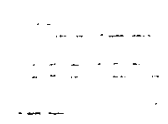 & rinite & 1974 & 57 & $22-93$ & & $\begin{array}{l}\text { Bzanklin Bllí, } \\
\text { Sagavani-ktok River, } \\
\text { Alaska }\end{array}$ \\
\hline
\end{tabular}


the upper extremity, and between landmarks $B$ and $A$ further down slope. The falcons frequently followed the ridgeline between landmarks $C$ and 3 and oriented their leparture flights in a southwest direction, or flew southward over the canyon from various locations in the vicinity of the eyrie. This is a natural pathway because it takes acvantage of the 1 i⿰t provided by the prevailing winds coming up the slopes of the canyon, and the canyon expands out into a wide valley (Knight's Valley) with an sbundance of sleared fields and open foraging habitat. Nenzel and Gheen (1975) observed the Zeregrines, which fomerly nested at Mt. St. Felena, soraging as far as 4.85 kilometers in the same difection, and it is probable that the foraging zange includes much of knight's Valley. Many other flights were observed to be oriented eastward to southeastward from the eyrie over the ridge extending from observation Post 1 to landmark A. The easter slope drops off abruptiy and another valley lies to the east. Approximately 68 percent of all observed foraging flights were seen to be oriented in the directions mentioned above (Table 4).

$\underline{P=e y}$

The 1978 search for grey remains at and near the yt. St. Helena eyzie, and subsequent identification of the specinens found revealed that the number of species exploited by the falcons may have been greatly reduced from the previous year. The reduction from 22 to 13 species could signify a shift in the foraging habits of the adult peregrines through the formulation of search images for preferfed prey species, and/or a greater familiaritg with the foraging habitat. Wenzel, Gheen and Hunt have emphasized the relatively high inportance value of columbiform species (i.e. pigeons and doves) as a prey base at the palisaces eyrie. In 1975 penzel and Gheen reported that 
Table 4 Difectional orientation of Foraging Elighes from the Mount Sairt Helena Peregrine Falcon Ejrie in 1978.

Directional

orientation

$\checkmark$

NE

$\mathbf{E}$

58

$s$

SW

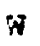

MT
Number of

Map ? Iots

3

3

12

8

11

19

5

4
Pezcentage of

Total yap ?lots

\section{6}

4.5

18.5

12.3

16.9

29.2

7.7

6.2 
the Domestic pigeon or Rock Dove comprised 58.5 percent of the total biomass of prey brought to the eyrie and Columbiform species collectively (Rock Doves, Band-tailed Pigeons and Mourning Doves) constituted 69.4 percent of the total biomass of prey from 58 item observed. Hunt observed that 72 percent of the total biomass of prey were Rock Doves in the Sollowing year. The high proportion of Columbiform birds in the diet of breeding Peregrine Falcons was also reflected in the food remains found at the Mt. St. Eelena eyrie in 1978, with 67.3 percent of the total prey biomass among 40 items (Fable 5). Other species which appear to have been important, and perhaps preferentially selected by the falcons, included Acom Noodpeckers, Scrub Jays and Starlings. Pigeons and doves were also observed to be important prey items at Mt. St. Felena in 1977 by the author and in 1975 by Wenzel and Gheen. This tendency of preferential selection of columbiform birds by Peregrine Falcons has been well documented in other regions. If the prey base at Mt. St. Belena is broader than the 1978 data suggest, then the diversity of potential prey species in the study area should reflect its relative importance as a foraging habitat. Also, since the habitat in the study area is heterogeneous with respect to biotic communities, an evaluation of prey species diversity in each community would be relevant. The data presented in Table 6 show that avian species were most diverse in the mixed evergreen, riparian and oak woodland communities which comprise much of the nataral vegetation in the Mt. St. Helena area. Agricultural lands in Franz Valley also provide habitat for such important prey species as Rock Doves and Mouraing Doves (mable 6 ).

Territorial Defense Flichts

The observers frequently withessed aggressive aerial assaulis on avian intruders by the adult peregrines in the nesting tarzitory at Mt. St. ielena 


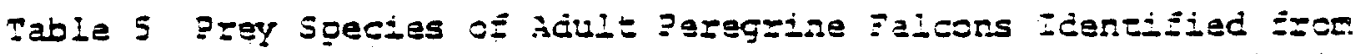
Proy Rernains at or vear the Mount Sajnt ielena EYlie in 1973.

\begin{tabular}{|c|c|c|c|}
\hline Pzoy Species & Insisez & $\begin{array}{l}\text { an iveight } \\
\text { (ezans) }\end{array}$ & $\begin{array}{l}\text { Percent } \\
\text { 3iorrass }\end{array}$ \\
\hline Rock Sove (Colimica livida) & 3 & $3 \div 3 *$ & 40.3 \\
\hline Eand-cailed Pigeon (C. Easciata). & 3 & $350 *$ & 17.3 \\
\hline Mourging Dove (Zenaicura macsoura) & 5 & 125 & 9.2 \\
\hline Comon Elicker (Calaptes auratis) & 2 & $137^{+}$ & 4.4. \\
\hline 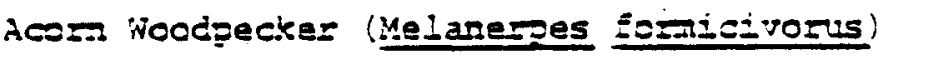 & 5 & $65^{*}$ & 5.2 \\
\hline 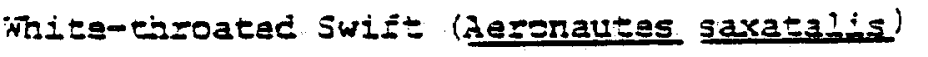 & 1 & $25 *$ & 0.4 \\
\hline Stellar's Jay (Granoci=sa steIleri:) & 2 & 88* & 2.3 \\
\hline Sc= Jay (Aphelocema coerilescens) & $\Xi$ & $79 *$ & 6.2 \\
\hline Conmon Csow (Cortus iracivylhycios) & 1 & $420=$ & 6.7 \\
\hline Starling (sterrug rulearis) & 3 & $77 * *$ & 3.7 \\
\hline 3rewer's Blackbi C (Eupiagus granoceshalus) & 2 & $5 \overline{5}$ & 1.8 \\
\hline Red-winged 3lackizad (jgelaius phoericeus) & I & $58 * *$ & 0.9 \\
\hline ParËous-siced Towhee (Pipilo ertizopthal-us) & 1 & $37 *$ & 0.5 \\
\hline unidentisied & 1 & $-\infty$ & - \\
\hline TOTAIS : 13 SPECEIS & \multicolumn{2}{|l|}{40 ?PEY } & 100 egso \\
\hline
\end{tabular}

- Henzel and Gheen 1975. Erom omithologieal collection a Universigy of Califorria, Davis.

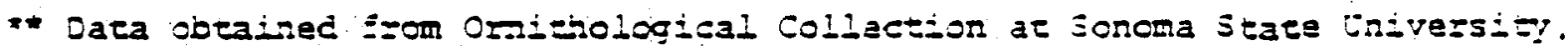


Table 6 bird Species Observed within the Peregrine Falcon Foraging llabitat at Mount Saint llelena in 1970

\begin{tabular}{|c|c|c|c|c|c|c|c|}
\hline Species & Cliffs & Chaparral & $\begin{array}{c}\text { Mixed } \\
\text { Evergreen }\end{array}$ & Riparian & $\begin{array}{c}\text { Oak } \\
\text { Woodl and }\end{array}$ & Pond & Agricultural \\
\hline Great Hlue lleron & & & & & & $x$ & \\
\hline rurkey vulture & $x$ & $\mathbf{x}$ & $x$ & $x$ & $x$ & $x$ & $\mathrm{x}$ \\
\hline Copper's llawk & & & $x$ & $x$ & & & \\
\hline Red-talled llawk & $x$ & $x$ & $\mathbf{x}$ & & $x$ & & $x$ \\
\hline Red-shouldered llawk & & $x$ & & & $x$ & & \\
\hline Golden Lagle & $x$ & $x$ & & & $\mathbf{x}$ & & \\
\hline Ninerican Kestrel & & & & & $x$ & & $x$ \\
\hline Calitornia Suáil & & $x$ & & $x$ & $x$ & & \\
\hline Mounta in suati i & & $x$ & $x$ & $x$ & & & \\
\hline Band-tallea Pigeon & & & $x$ & & $x$ & & \\
\hline Rock bove & & & & & & & $x$ \\
\hline Motining Dove & & & & & $x$ & & $x$ \\
\hline Sicreech ow 1 & & & $x$ & $\mathrm{x}$ & $x$ & & \\
\hline Great Horned (owl & & & $\mathrm{x}$ & $\mathrm{x}$ & $x$ & & \\
\hline l'yogliny owl & & & $x$ & & $x$ & & \\
\hline
\end{tabular}


Table 6 - contirued/

\begin{tabular}{|c|c|c|c|c|c|c|c|}
\hline species. & Clifts & Chaparral & $\begin{array}{c}\text { Mixed } \\
\text { Evergreen }\end{array}$ & Mparian & $\begin{array}{l}\text { Oak } \\
\text { Woodl and }\end{array}$ & Fond & Agricultural \\
\hline Poorwill & & $x$ & & & & & \\
\hline Mite-throated swift & $x$ & & & & & & \\
\hline Amila's Ilununfugbird & & $\mathbf{x}$ & & & & & \\
\hline lufous Hununingloird & & & $\mathbf{x}$ & & & & \\
\hline Aljen's llumainubird & & $x$ & $\mathbf{x}$ & & & & \\
\hline nelted Kingfisilex & . & & & & & $x$ & \\
\hline Conumon blicker & & & $x$ & & $\mathbf{x}$ & & \\
\hline Pileated Woodpecker & & & $\mathrm{x}$ & & & & \\
\hline Acorn Woodpecker & & & $\mathrm{x}$ & & $\mathbf{x}$ & & \\
\hline Iáiry Woodpecker & & & $x$ & & & & \\
\hline Downy Woodpecker & & & & $x$ & $x$ & & \\
\hline Nullall's Woodpecker & & & & & $x$ & & \\
\hline Western Kingloird & & & & & $x$ & & \\
\hline Asli-throated Hycatcher & & $x$ & $x$ & & $x$ & & \\
\hline II ack Hhoutis: & & & & & & $x$ & \\
\hline
\end{tabular}


'Table 6 - Continued/

\begin{tabular}{|c|c|c|c|c|c|c|c|}
\hline Species & cliffs & Claparral & $\begin{array}{c}\text { Mixed } \\
\text { Eivergreen }\end{array}$ & Miparian & $\begin{array}{l}\text { Oak } \\
\text { Woodland }\end{array}$ & Pond & Agricultural \\
\hline Western Flycatcher & & & $x$ & $x$ & & & \\
\hline Western Wood Pewee & & & $x$ & & & & \\
\hline Olive-sided Flycatcher & & & $x$ & $x$ & & & \\
\hline violet-green Swallow & & & $\mathrm{x}$ & & $\mathrm{x}$ & & \\
\hline Stellar's Jay & & & $x$ & & . & & \\
\hline Scrub Jay & & $x$ & & & $x$ & & \\
\hline Common Kaven & $x$ & & $x$ & & $\mathbf{x}$ & & \\
\hline Chestnuc-backed Chickadee & & & & & $\mathbf{x}$ & & \\
\hline Plaill Pitmouse & & & & & $x$ & & \\
\hline Uushtit & & $\mathbf{x}$ & $x$ & & $x$ & & \\
\hline White-lireasted Nuthatch & & & $\mathrm{x}$ & & & & \\
\hline Red-breasted Nuthatch & & & $x$ & & & & \\
\hline I'yomy Nuthatch & & & $x$ & & & & \\
\hline Hrown cretper & & & $x$ & & $x$ & & \\
\hline
\end{tabular}


rable 6 ... Continued/

\begin{tabular}{|c|c|c|c|c|c|c|c|}
\hline Species & Cliffs & Chaparral & $\begin{array}{l}\text { Mixed } \\
\text { Evergreen }\end{array}$ & Riparian & $\begin{array}{c}\text { Oak } \\
\text { Woodl and }\end{array}$ & Pond & Agricultural \\
\hline Wrentit & & $x$ & & & & & \\
\hline House Wren & & & & & $x$ & & \\
\hline Hewlek's Wren & & $x$ & $x$ & & $x$ & & \\
\hline Callyon Wren & $x$ & & & & & & \\
\hline Mockingloird & & & & & & & $x$ \\
\hline Callfornia 'lirasher & & $x$ & & $x$ & 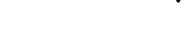 & & . \\
\hline American Koluin & & & $x$ & & $x$ & & \\
\hline Western IIIUels Ird & & & & & $\mathbf{x}$ & & \\
\hline Hluc-gray Griatcatcher & & $x$ & & & & & \\
\hline starling & & & & & $x$ & & $x$ \\
\hline llutton's Vireo & & & $x$ & & $x$ & & \\
\hline Solitary Vireo & & & & & $\mathbf{x}$ & & \\
\hline Warbling vireo & & & $\mathbf{x}$ & $x$ & & & \\
\hline Orangle-crowned Warbler & & & $x$ & & $x$ & & \\
\hline Hack-throuted liray Way & & & $x$ & & & & \\
\hline
\end{tabular}


'able 6 - Continued/

\begin{tabular}{|c|c|c|c|c|c|c|c|}
\hline species & cliffs & Chaparral & $\begin{array}{c}\text { Mixed } \\
\text { Evergreen }\end{array}$ & Riparian & $\begin{array}{c}\text { Oak } \\
\text { Woodland }\end{array}$ & Pond & Agricultural \\
\hline Yellow Warbler & & & $\mathbf{x}$ & $x$ & & & \\
\hline 'fownsend's Warbler & & & & & $x$ & & \\
\hline Mcrillivray's Warbler & & $\mathbf{x}$ & & & & & \\
\hline wilson's Warbler & & & $\mathbf{x}$ & $\mathbf{x}$ & & & \\
\hline Med-winged Blackbird & & & & & & $x$ & $\mathrm{x}$ \\
\hline Hrewer's Hackbird & & & & & & & $\mathrm{x}$ \\
\hline Western lanager & & & & & & & $x$ \\
\hline Iazuli Hunting & & $\mathrm{x}$ & & & $\mathbf{x}$ & & \\
\hline Purple Finch & & & $x$ & & $\mathrm{x}$ & & \\
\hline House linch & & & & & $x$ & & $x$ \\
\hline line Siskin & & & & & $x$ & & \\
\hline I.esser Goldfinch & & & $x$ & & $x$ & & \\
\hline Rufous-sided Iowhee & & $x$ & $\mathrm{x}$ & & $x$ & & \\
\hline Brown dowhee & & $x$ & & & $\mathbf{x}$ & & \\
\hline
\end{tabular}


'able 6-- continued/

\begin{tabular}{|c|c|c|c|c|c|c|c|}
\hline Species & cliffs & Chaparral & $\begin{array}{c}\text { Mixed } \\
\text { Evergreen }\end{array}$ & Riparian & $\begin{array}{l}\text { Oak } \\
\text { Woodl and }\end{array}$ & Pond & Agricultural \\
\hline Lark Sparrow & & & $x$ & & $\mathbf{x}$ & & \\
\hline Dark-eyed Junco & & & $x$ & & $x$ & & \\
\hline TOI'AL. SPECIES: 77 & 6 & 20 & 40 & 13 & 43 & 5 & 12 \\
\hline
\end{tabular}


in 1978. A total of 32 attacks were recorded for interspecific encounters with Red-tailed rawks, Golden Eagles, Turkey Vultures, a Prairie galeon and a Raver (Table 7). One intraspecific interaction was observed when a foreign adult male Peregrine Falcon wandered into the nesting terzitory and was forced out by the gesident adult female ('able 7). Funt 1976) reportad that Golden Eagles elicited the most intensified terfitorial defense behavicr in the adult falcons at the Palisades eqrie. Mree such attacks were seen to extend to 550 meters from the eyrie. Similar observations were made at the Mt. St. Helena site in 1978 but the encounters were much more Erequent because a pair of adult Golden Eagles nested at landnark D approxinately 400 meters from the falcon eyrie. Their novements to and from their eyzie constantly provoked the Peregrines to attack. The Eailure of the eagles to Sledge young may have been dne to the constant harrassment by the faicons. Vigorous attacks on Golcen Eagles at Mt. St. Eelena were observed at Cistances of up to 2 kilometers in 1978 with a gean cistance of 767 meters $(n=9)$. Bunt obserred that Rec-tailed rawks were pursued by the falcons to a mean distance of 330 meters from the Palisades eyrie and such attacks were much more frequent (22 recorded) probably because a paif of hawks rested in the vicinify of the falcon eyrie. Again the observations at the Mt. St. Eelena eyrie yielded similar results, with a mean bistance for attacks on Redtailed flawks of 500 meters. It should also be noted that a pair of hawks nested just south of landmark $C$ approximately one kiloneter from the Falcon eyrie.

Attacks on rurkey pultures were Erequent at both eyries because the ruleures habitually soared close to the eyrie clisfs to vake advantage of lift, but the falcons allowed tiese bizds to aporoaci to elose proxinity to the eyries before initiatirg assaules and on numerous occasions rultures passed by with inpunify. The mean observed attack distances on Turkey Yultures 
Tale 7 Territorial Defense Plighes of Alull peregrine Palcens at the Moune Saint Helena Ey

\begin{tabular}{|c|c|c|c|c|c|}
\hline Date. & $\begin{array}{r}\text { Se: } \\
\text { se=-2 }\end{array}$ & $\begin{array}{l}x \text { of } \\
\text { Letere (s) }\end{array}$ & $\begin{array}{l}\text { Intruder } \\
\text { Species }\end{array}$ & $\begin{array}{l}\text { Discance (merezs) } \\
\text { and oirecticn of } \\
\text { Atzack Szom Evzie }\end{array}$ & $\begin{array}{c}\text { Otier } \\
\text { Cose-rations }\end{array}$ \\
\hline $4 / 9$ & $\underline{x}$ & $s ?$ & Praizie Paleon & 100 & $\begin{array}{l}\text { Attack bzoken of by both } \\
\text { Peregrifes at } 100 \mathrm{~m}\end{array}$ \\
\hline $4 / 10$ & & $M$ & Red-Tailed lawk & so & $\begin{array}{l}\text { Intruder struck and Sorced } \\
\text { to gerci }\end{array}$ \\
\hline $4 / 16$ & & $x$ & Turkey Vul=ure. & lost & $\begin{array}{l}\text { Intruder ciased out of } \\
\text { sight: both Ealeons yoeal }\end{array}$ \\
\hline $4 / 21$ & & $\Xi$ & Golcen Eagle & $1300 \quad \sqrt{E}$ & $\begin{array}{l}\text { Zajesn stsoped } 5 \text { ines, } \\
\text { not vocal }\end{array}$ \\
\hline $4 / 22$ & & $x$ & Golden Eagle & scove $v=05$ & $\begin{array}{l}\text { Intucier ateacked repeated- } \\
\text { ly until out of sight }\end{array}$ \\
\hline $4 / 28$ & & $M$ & Tu-kay Vulturs & : $5=0$ & $\begin{array}{l}\text { Atzack srsken off at } 40 \mathrm{~m} \\
\text { szon eyrie, } 8 \text { stoops }\end{array}$ \\
\hline $4 / 29$ & & $\Sigma$ & Red-Tailed Gawk & below & $\begin{array}{l}\text { Latuder attacked and } \\
\text { jorfed to perah, jalcon } \\
\text { vocal }\end{array}$ \\
\hline $5 / 2$ & & $\mathrm{M}$ & Turkey Vulture & 20 & $\begin{array}{l}\text { Intruder struck and Eoreed } \\
\text { to ciance jirection }\end{array}$ \\
\hline $5 / 3$ & & $\Xi$ & Golder Eagles (2) & $500 \Xi$ & $\begin{array}{l}\text { Pair of eagles were stooped } \\
\text { at altermately by } \text { inicon }\end{array}$ \\
\hline $5 / 4$ & & $z$ & Golcen Eagle & seove $\mathrm{N}$ & $\begin{array}{l}\text { Inezider zuzsued out of } \\
\text { sight to inN }\end{array}$ \\
\hline $5 / 6$ & & $\mathbf{n}$ & maxey VuIfare & so & $\begin{array}{l}\text { Intucier aporsacied below } \\
\text { level of eysie; falcon rocal }\end{array}$ \\
\hline $5 / 7$ & 4 & $s \bar{E}$ & Golden Eagles (2) & $500 \Xi$ & $\begin{array}{l}\text { Ealcons atzacked adult pai= } \\
\text { of eacles repeasediy }\end{array}$ \\
\hline $5 / 7$ & & $\therefore$ & Golden Eagle & $\begin{array}{l}500 \equiv \\
1000 \text { high }\end{array}$ & $\begin{array}{l}\text { Ineruder sorsed to zeverse } \\
\text { difection }\end{array}$ \\
\hline $5 / 16$ & & $\because 4$ & Red-Tailed :awk & $\begin{aligned} 100 & \sqrt{\varepsilon} \\
50 & \text { above }\end{aligned}$ & 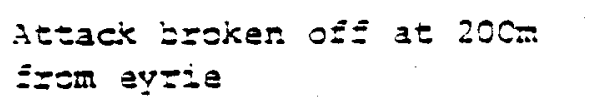 \\
\hline $5 / 17$ & & $y$ & Golden Eagle & $\$ 00 \quad \sqrt{E}$ & $\begin{array}{l}\text { ineruder stocped at j ines } \\
\text { by jaleon }\end{array}$ \\
\hline
\end{tabular}


Table 7 -- Continued/

\begin{tabular}{|c|c|c|c|c|}
\hline Date & $\begin{array}{c}\text { Sex of } \\
\text { Atteacke }=(s)\end{array}$ & $\begin{array}{l}\text { Intruder } \\
\text { Species }\end{array}$ & $\begin{array}{l}\text { Distance (meters) } \\
\text { and Direction of } \\
\text { Attack from Evzie }\end{array}$ & $\begin{array}{c}\text { Other } \\
\text { Obserrations } \\
\end{array}$ \\
\hline $5 / 17$ & $x$ & Turkey Vulture & $500 E$ & $\begin{array}{l}\text { Attack broken off above } \\
\text { ORI } 350 \mathrm{~m} \text { from eyrie }\end{array}$ \\
\hline $5 / 18$ & $M$ & Red-Tailed Hawk & $350 \mathrm{SE}$ & $\begin{array}{l}\text { Intzuder pursued beyond } \\
\text { OP } 1 \text { reading SSE }\end{array}$ \\
\hline $5 / 24$ & $x$ & Golien Eagle & $500 \mathrm{NE}$ & $\begin{array}{l}\text { Intruder pursued out of } \\
\text { sight }\end{array}$ \\
\hline $5 / 25$ & $\Gamma$ & Raven & 50 & $\begin{array}{l}\text { Intzuder forced to change } \\
\text { direction away from eyrie }\end{array}$ \\
\hline $5 / 27$ & $M$ & Golden Eagles (2) & $500 \mathrm{NE}$ & $\begin{array}{l}\text { Pair of eagles stooned at } \\
\text { aitemately by falcon }\end{array}$ \\
\hline $5 / 27$ & $\Xi$ & Turkey vulture & $50-100 \mathrm{SE}$ & $\begin{array}{l}\text { Attack broken off } 10 \mathrm{Cm} S E \\
\text { of eyrie }\end{array}$ \\
\hline $5 / 27$ & $F$ & Turkey vulture & $50 \%$ & $\begin{array}{l}\text { Inezuder forced to change } \\
\text { direction toward is } \mathrm{C}\end{array}$ \\
\hline $5 / 27$ & $E$ & Turkey vulture & $\Sigma$ & $\begin{array}{l}\text { Intzuder pursued heading } \\
\text { out of sigtt; falcon vocal }\end{array}$ \\
\hline $5 / 28$ & $M$ & Golden Eagle & & $\begin{array}{l}\text { Falcon stooped } 100 \mathrm{~m} \text { at } \\
\text { eagle and eagle evaced the } \\
\text { atcack }\end{array}$ \\
\hline $5 / 29$ & $z$ & $\begin{array}{l}\text { Peregrine Falcon } \\
\text { (adult } M \text { ) }\end{array}$ & Siv & $\begin{array}{l}\text { Intrader pursued out of } \\
\text { area uttezing Eaar call } \\
\text { notes }\end{array}$ \\
\hline $5 / 30$ & $M \& F$ & Golden Eagle & 500 N $\sqrt{E}$ & $\begin{array}{l}\text { Both Ealcons attacked } \\
\text { eagle simultaneousiy }\end{array}$ \\
\hline $5 / 31$ & $x$ & Golden Eagle & & $\begin{array}{l}\text { Ealcon stooped at eagle } \\
\text { from 300m above, then } \\
\text { eagle stooped at falcon }\end{array}$ \\
\hline $6 / 9$ & $z$ & Golcen saole & 2000.5 & $\begin{array}{l}\text { Falcon stooped } 3 \text { tines } \\
\text { near LM A: attack broken } \\
\text { off }\end{array}$ \\
\hline $6 / 14$ & M & Red-Tailed Jawk & $2000 \mathrm{sw}$ & $\begin{array}{l}\text { Falcon atzacked hawi once } \\
\text { near Ly } 3 \text { and continued } \\
\text { heading si }\end{array}$ \\
\hline
\end{tabular}


Table 7 - Coneinued/

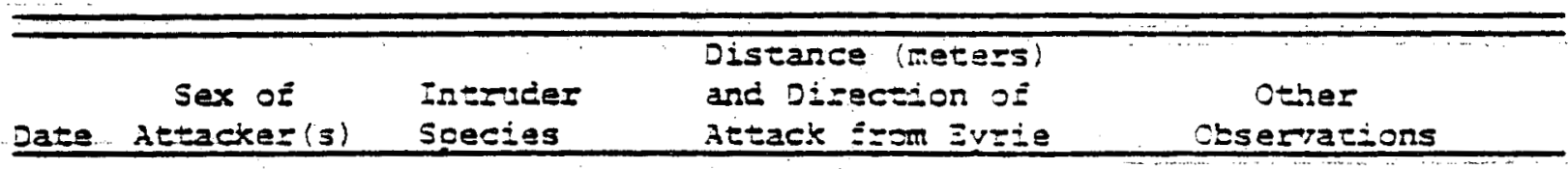

6/15 M Rarkey Vulzase above

Entrader strack by Ealeon and pursued heading $\Xi$; Paleon rocal

$6 / 22 \quad M \& F \quad$ Red-Tailed Eawk

10

3oth Saleons attacked sinultareous ly; atzack broken of zear in $C$

$5 / 25 \quad$ Red-Tailed Bawi $500 \mathrm{SoJ}$ 
were doserved to be 58 geters $(n=11)$ at the Palisades eyrie and 98 meters $(n=7)$ at Mt. St. helena. Other intruder species occurzed only once per breeding season and were too infzequent to evaluate their relative importancs quantitatively. The above mentioned observations on territorial defense behavior of the falcons during encounters with Golden Eagles, Red-tailed Fawks and Turkey Vultures are supported by similar findings in the 1977 stedy. (see Appendix).

In the moning of $18 \mathrm{June} 1978$ a hum intuder inacvertently hiked to the top of Landmark $D$, approximately 350 meters from the Ealcon eyrie and provoked the falcons into intense agitation. The adult nale flew back and forth along the cliff face in front of the eyrie rocalizing loudly. Ye continued this behavior for five minutes until he was joined by the adult female and they proceeded to alternate tiese displays for 15 more minutes until the aiker descended below the ridgeline into the forest. This incident stresses the importance of preventing people from approaching peregrine Eyries from above during the critical nesting period and the need for the continuation of the surveiliance program.

grom tise above observaticns it can be concluded that the nest site defense tersitory at the Mt. St. Belena eyrie extends to a zadius of approximately 2 kilometers and protection of this area must be considered essential to the long-tern survival of the Peregrine galcons at this site

\section{Breeding Grele Curonology and Fledging success}

The onset of the breeding cycle was observed to be earlier at Mt. St. Eelena in 1978 than during the preceeding year, which nore closely conformed to the nomal tining sor the species it Califoria (Bent 1938). The unusualiy late, but successiul, nesting in 1977 nay have been the result of exinended time required for the initial paiz-iond Eomation following the period of 
iractivify of the aesting site. A similar delay is the Peregrise Falcon reproductive glele was obserped by the author in Mexico when the individual Ealsons fated so reactivate as old site were under continuous obserpation at zo locations. As previously stated, dates for elutei formation and hacching were estimated by observing the behavior of the adules and the lledging dates were establisied by direct obserration of the rirgin flights: of the yous falcons. The ?erggrines at the zalisades eyrie vero romarkably consistent during the 1975 and 1976 breeding seasons and the comencement of nesting turing the to years was in adrance of the Mt. St. Jelena site by approximately fNo months in 1977 and a litiste under three weeks in 1978

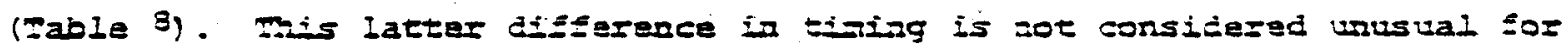
the species is regions where seasonal clinatis shifts are not severe in contrast to the arcice tadya Peregrime population (Cade 1960).

From 1970 to 1978 the Sledging sucsess has been monitored at the two persgriae falcon eyries eonsiderad in this discession. The resulis of these abserrations bave been presented is Table 9 which show hat a tetal of 14 young bave fledged in Eire seasons at the $\mathrm{xt}$. St. Relena eyrie Sor a near of 2.3 Iledged, and 18 young Eledged is seven seasons Ecr a mean of 2.5 Eledged at the ?alisades eytie (mable 9 ). In light of the wide-soread zeproductive failure of the species elsewhere in voril imerica (Eickey 2968 , Endarson 1967, Herman, Kifven and issebrough 1970, ibite 1975) the Eledging sucsess of the falcons at these sites must be considered excepticrally high and emphasises the need Sor presertation of the habitats consiciered in these stadies.

me sate of Eledglings at the ut. St. Relena eysie could sot be deterrined in the absence of telemett data, but some noteworisy obserpations were

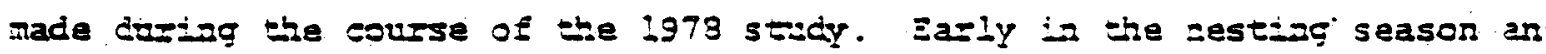


Table 8 The Chronology of the Peregrine Falcon Breeding Cycle in the known Geothermal Resources Area.

\begin{tabular}{|c|c|c|c|c|c|}
\hline Authority & Year & $\begin{array}{l}\text { Eqg Laying } \\
\text { Dates }\end{array}$ & $\begin{array}{l}\text { Satcing } \\
\text { Dates }\end{array}$ & $\begin{array}{l}\text { Bledeing } \\
\text { Dates }\end{array}$ & Eocation \\
\hline Wenzel and Gheen & 1975 & $3 / 22-25$ & $4 / 25-26$ & $5 / 5-5$ & $\begin{array}{l}\text { Palisades, Vapa } \\
\text { County, California }\end{array}$ \\
\hline Funt & 1976 & $3 / 19-22$ & $4 / 22-23$ & $6 / 3$ & $\begin{array}{l}\text { Palisades, lapa } \\
\text { County, CaliEornia }\end{array}$ \\
\hline Kinven & 1977 & $5 / 19-22$ & $5 / 22-24$ & $8 / 4-6$ & $\begin{array}{l}\text { Mt. St. Felena, } \\
\text { Sonoma countl, } \\
\text { California }\end{array}$ \\
\hline Rizren & 1978 & $4 / 7-10$ & $5 / 12$ & $6 / 25-25$ & $\begin{array}{l}\text { Mt. St. Helena, } \\
\text { Sonoma County, } \\
\text { California }\end{array}$ \\
\hline
\end{tabular}


Table 9 Fledoing sucsess of zezegrine Zalcons iesting in the krown Geothernal Resourses Area.

\begin{tabular}{|c|c|c|c|c|c|c|c|c|}
\hline \multicolumn{3}{|c|}{ Authorit=r } & \multirow{2}{*}{$\frac{Y \text { ser }}{1970}$} & \multirow{2}{*}{$\begin{array}{l}\text { Numiber } \\
\text { Sledged } \\
2\end{array}$} & \multicolumn{4}{|c|}{ Location } \\
\hline Wenzel & and & Gheen & & & & Mt. & st. & Belena \\
\hline$"$ & $"$ & $"$ & 1971 & 3 & & $"$. & $"$ & $"$ \\
\hline " & $"$ & $"$ & 1972 & 3 & & $"$ & $"$. & $"$ \\
\hline Kiner & & & 1977 & 3 & & $"$ & $"$ & $"$ \\
\hline \multirow[t]{2}{*}{$"$} & & & 1978 & 3 & & $"$ & $"$ & $"$ \\
\hline & & & & $\therefore: 14$ & \multicolumn{4}{|c|}{ Mean: 2.8} \\
\hline Henze1 & and & Green & 1970 & 3 & \multicolumn{4}{|c|}{ Palisaces } \\
\hline$"$ & $"$ & $"$ & 1971 & 2 & \multicolumn{4}{|c|}{$"$} \\
\hline$"$ & $"$ & $"$ & 1972 & 4 & \multicolumn{4}{|c|}{$"$} \\
\hline$"$ & $"$ & $"$ & 1975 & 2 & \multicolumn{4}{|c|}{$"$} \\
\hline ع عسب: & & & 1976 & 2 & \multicolumn{4}{|c|}{$"$} \\
\hline$"$ & & & 1977 & 4 & \multicolumn{4}{|c|}{$"$} \\
\hline Barlow & & & 1978 & 1 & \multicolumn{4}{|c|}{$"$} \\
\hline & & & & $=: 18$ & \multicolumn{4}{|c|}{ Mean: 2.5} \\
\hline
\end{tabular}


imature male peregrine arrived at the eyrie and was apparently accepted by the pair of adults. On 18 Aprit he perched on the eyrie clifis and moved to a nearby tree gerth where he was joined by the adult semale with no sign of aggression on her part. He appearec at the eyrie cliff on two other occasions (28 April and II May) without eliciting territorial defense behavior in the adults. The only conclusion the author can make regarding these unusual obserrations is that this imature falcon fledged from the same eyrie during the preceeding year and has either remained in the area ever since or was drawn back to his familiar place of origin.

The 1978 fledglings were seen in the vicinity of the eyrie for a period of two months. They were not observed foraging successiuliy but abortive attempts to catch white-throated swifts near the elifs were fiequently observed as were food exchanges from the parents to their offspring. The author coserred a single female fledgling at the eyrie cliff on $26 \mathrm{July}$ and again on 20 August. On both ocsasions the falcon utterec begging ealis and the remains of Sreshly killed Mourning Doves were found at the rim of the eqrie cliff, presumably brought in by one or both of the adults from the valley below. Mis represents an unusually long period of post lledging parental care when compared to Arctic Peregrines (Cade 1960).

Floral and Faunal Diversity in the Study Area

The heterogeneous nature of the terrain and pegetation in the study area undoubtedy contribute to the remarkable biotic jiversing which is exemplified in the floral and verebrate faunal species lists included in this report (mables $10,6,11,12,13)$. With elements of at least seren biotic communities represented well within tie foraging range of the falsons, an ample food supoly for successiul zeproduction is assured as long as the habitat gemaiss unaltered by nan. Ang zemoval or simplifisaticn of these 


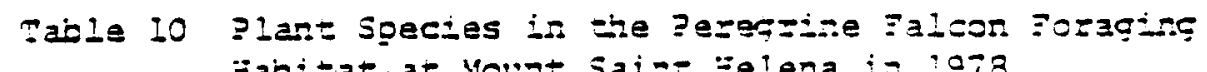
تabitat at Mount Sair:= :elena is 1078.

\begin{tabular}{|c|c|c|c|c|}
\hline & TRES & & & \\
\hline Aceraceae & icer macropiny?ium & 3ig-ieaf :aple & & \\
\hline Betulaceae & 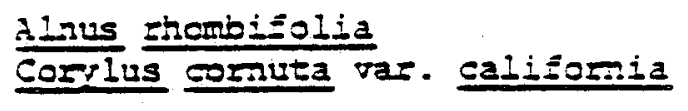 & $\begin{array}{l}\text { White Alcer } \\
\text { iazelnut }\end{array}$ & & \\
\hline Comaceae & Gorms mutea11ii & Mounzai] Dogwood & & 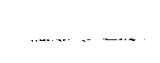 \\
\hline Cipressaceae & $\frac{\text { Cupzessus nacnabiana }}{\text { C- sargentij }}$ & $\begin{array}{l}\text { Nelab Cpozess } \\
\text { safgent's Crpyess }\end{array}$ & & \\
\hline E=icaceae & Arbu=as nenziesii & Macrone & & $-\cdots$ \\
\hline Zzgacese & 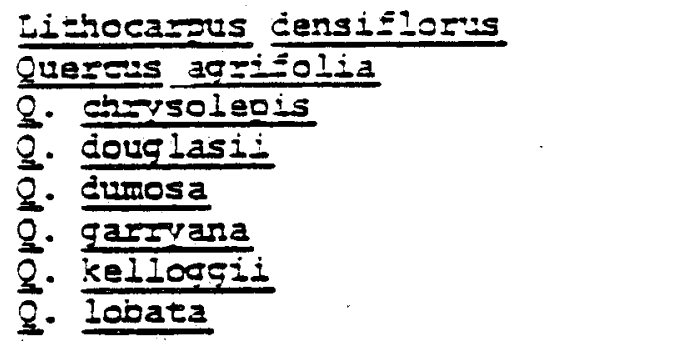 & 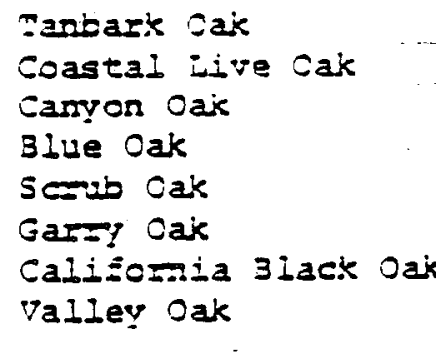 & 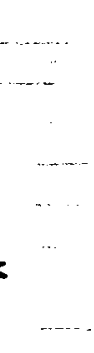 & $\begin{array}{ll}\cdots & \\
\cdots & \ldots \\
\cdots & \end{array}$ \\
\hline تipoocas tanaceae & Aescylus calíicaniea & Calisormia Buckeye & & $\because \ldots$ \\
\hline Laurzceae & Gmbellularia calisonaca & Calísonia $3 a y$ & & $\therefore \cdots \cdots$ \\
\hline Pinaceae & 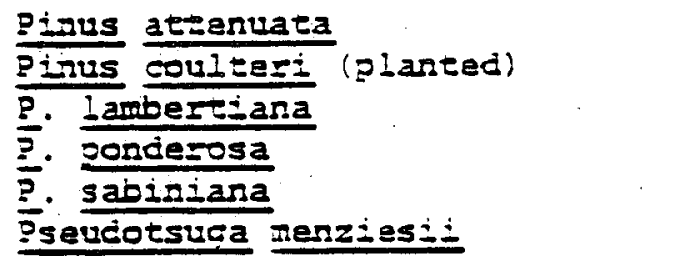 & $\begin{array}{l}\text { Wobcone Pine } \\
\text { Coultar ?ise } \\
\text { Sugar Pine } \\
\text { Ponderosa Pise } \\
\text { Digger Pize } \\
\text { Douglas Piz }\end{array}$ & & $\frac{-1}{\cdots+\cdots}$ \\
\hline Salicaceae & Salix lasioleois & AETOYO NI1LOW & & $\ldots$ \\
\hline Taxaceae & Torreva calisoraica & Califormia Nuteq & & $-\ldots i n$ \\
\hline Taxodiaceae & Secroia sempervijens & Pecwood & & $\cdots$ \\
\hline
\end{tabular}


SFRUBS

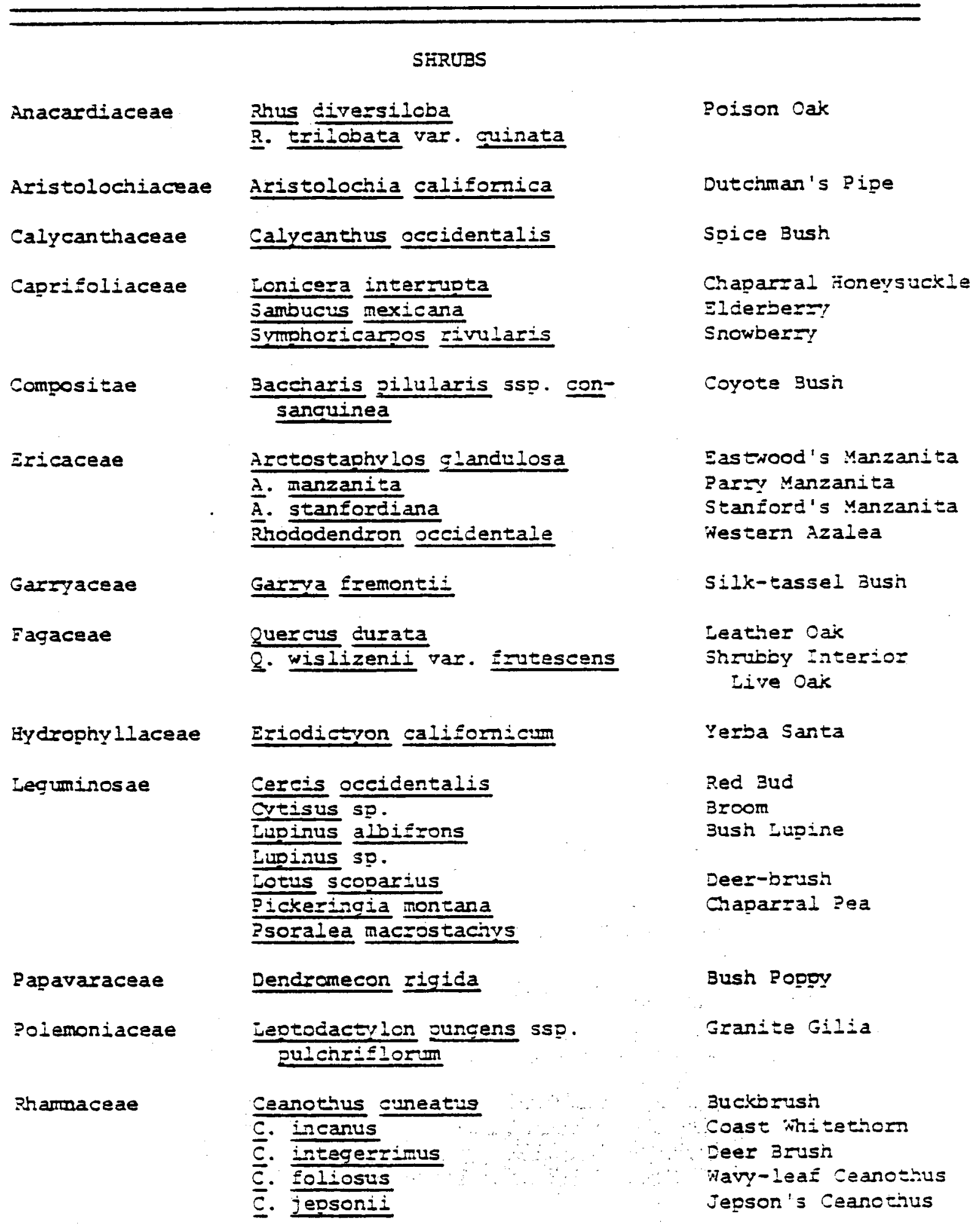

Table 10 - Continued/ 
Table 10 -- Continued,

Sh=ios: sontinued

Shamraceae

Rosaceae

Saxi三zagaceae

Scopiny lariaceae

Araliaceae
3oragisaceae

Araliaceae
3oragisaceae

Carpophy liaceae

Compositae

Amary liiciceae
Ceanotrus gargi-

C. zu>vireus

c. zamilosus

c. velurinus rar. hookeri

Thanmus calijornica

Adenostma Eascicalatin

cercocarrus jefiloides

ietsromeles arjutío-ia

Folociscis discolor

Rosa SD $=-$ imaea

Rubus discolor

Rubus ieucsdernis

Rubus SD.

Ribes guereetor=

Minulus aurantiacus

?enstermon sortrbosus

FERBS

Cerastium viscosum

S. rileatum

Stellaria media

Achiliea joreabis ssp. calisonica

Acoseris iererocinyla

agoseris zersorsa

Aremisia covelasiana

Carjurs oucroceghalus

Centaurea nelitansis

Centaurea solstisialis ?arf? Ceanothus

jolly lea canotius

Coast Ceanothus

Tobacso 3ush

Cofsee Berf?

Chamise

Mountain Marogan?

Soyon

Gaamiush

Grourci Rose

Iinalaya 3lackbery

Native Raspier=?

Vative 3lackicer=?

Oak Goosebe=?

Stick Monkey Ilower

Beard-tongue

Nidd onion

Califorma Irodiaea

Galizornia draiia

Tapa C=rptantha

iester. Founc's Tong:a

Popcern Flowe=

Mouse-ear Chickseed

cormon Chickweed

cisurneec

Yas?ow

Arnual Acoseris

iouncain Jancelion.

Mowor:

Italian maste

Napa Thistle

yellow-star Mniscle 
Table 20 -- Continued

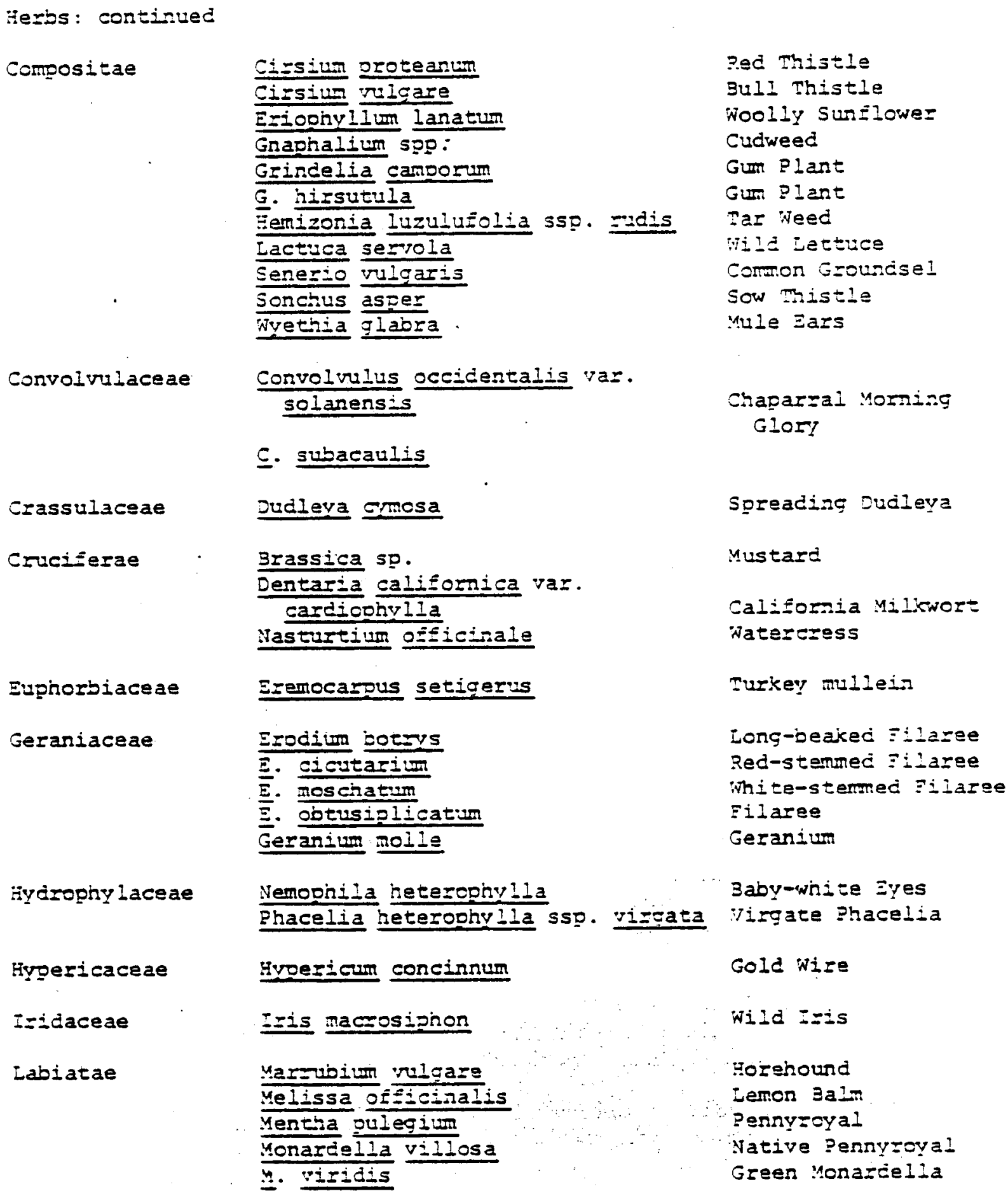


Table 10 - Contrued

Eexes : sontinusd

Fabiatae

Leguminosae

iticaceae

Loriceraceae

Papavaraceae

PIantacinaceae

Polemoniaceae

Polygalaceae

Polygonaceze

PYimilacaae

Rarureglaceae

Ribiaceae

Saxi=ragaceae
Salvia colingiarize Scuteliaria calíornica staciys Eigida sso. Eivularis

Latisy ous sp. Loters conienlatus totas humis zeacies Lotas suepirnatis Eupinus jicolor Evoinus latisolius isi=01iun alboourour

T. bifieum

$\bar{T}$. dichotornen

Vicia calísraisa

Calorogalinn pomeridianum iluin zicescens zicadenus Émenti

Lonicera hispiciula var. Jacillans

Eschscholzia calisoracica

Plantaco ianceolaca

inantius acicolaris Yavarzeria scuarrosa

Polycala sali sornisa

EIjgonum latijoliven 5sp. nudum E=igonum vinireum var. caninum Polyconum sp.

zumex acetose 1Ia

Rumex SD.

Anagolis agrensis Dodecatheor iencersoni: mientalis iatifolia

Clematis hasiartha Ranurculus ocsidentalis

Galiem bolander: G. zue =alí

injpolea modes a
Chia

Scoil-cap

Eedge Net=le

Shor-podded aosackia

aile rosackia

iupire

Eroad-Leaved Lupine

Clover

Pirole Ciovez

Branchec Indian Clover

Calizornia vers:

Soap ? lant

sear iily

Roneysuckie

Calisormia ?opg

Plascais

3ristiy ingantius

Skusk Need

Calisonia Mijixors

Buckineac

3uckiriseat

Rrotweed

Sheep Sorza I

Dock

Scarlet ?impersel

Shootine star

star-flower

Clematis

Hester. 3u=sercup

Bedstzaw

Ci-bing Jecis=-зw

Modes $=$ 
Table 10 -- Continued/

Herbs: continued

Sczopinulariaceae

Solanaceae

Tyohaceae

Umbelifierae

Vitaceae

Gramineae
Castilleja so.

Cortvlanthus tenuis sso. byunneus

Dedieularis densifiorus

Penstemon jzevifiorus

Penstemon heterophyllus

penstemon lemunonit

Verbascum irapsus

Solanum sp.

Trona latisolia

Eoeniculum vulgare

Lomatium repostum

Torilis afrensis

I. nodosa

Vitis calisornica

GRASSES

Aira carrophylia

Avena barbata

Briva maxima

Briya minor

Bromus carinacus

Bromus diandius

Bromus marijatis

Bramis molits

Bromus Iivens

Bromus iecsorin

Cyosuras eerinatus

Cynodion dactylon

Elymus caput-medusae

Elymus glauess

Elymus triticoides

Bestuca calizornica

iestuca icanoensis

Festuca iegalura

Gastricium ventricosum

Horceum jubatum

Lolivim SD.

Phalaris so.

Polvooson interziptes

polvoogon nonspeliersis

sitanium hystzix

Stipa lepica
Indian Paint 3rush

3izd's-beak

Indian farrior

Gaping Penstemon

Beard-tongue

Mullein

Catsail

Eennel

Napa Lomatium Hedoe Parsley

unotted Hedge Parsley

Calisomia Grape

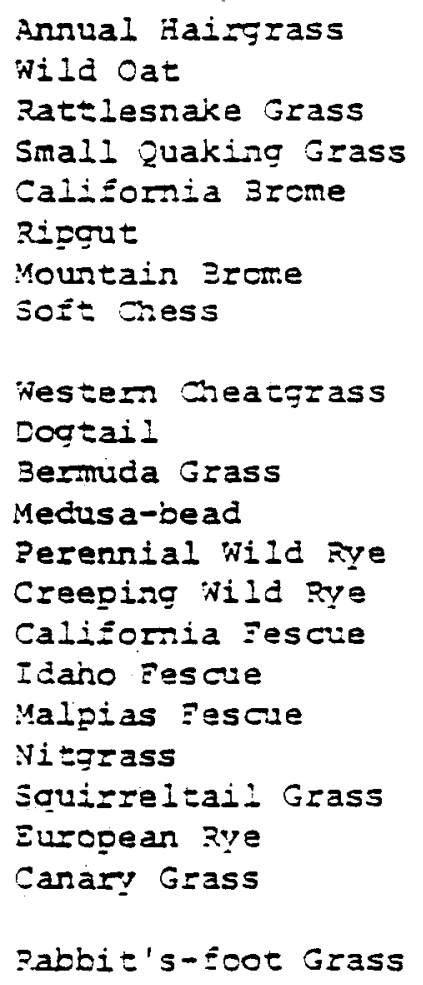


Table 10 -- Sontirued/

FERNS, SEDGES I RUSHIES

\section{Eerss}

Aspidaceae

3lechraceae

Dolpoodiacsae

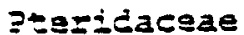

Seders

Equise tacsae

Juncaceae
Atry=ium Eilix-femira var. califormicin

Polyseichum calisoriciean

Polystichum ㄲanitin

Woocinardia Birbriata

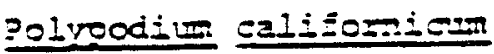

idiantum ioriani

Onvcitum densun

Jellaea andromedaefolia

Peliaea mucinaca

Pijrocrama Eiancularis

Pteridium acuilizun var. lanugizosum

Lady Fer.

California Sword Zer:

Western Sword Fer.

Nestern Chain Eern

California Poivsocty

California Maicieriai=

C1i泣-jrake

Cofíee Bern

zird's poot ze=

cole-iack Eer:

Bracken Eer.

Forsecail

Bzivie Rusi

juneis baleiess

jureas bufonius

Juncess ef:isus

Junces ensizolins

Juners satens 
Table 11 Mammals in the Study Area

\begin{tabular}{|c|c|}
\hline vagrant shrew & sorox vacanas \\
\hline Trowbridge Shrew & s. Eowbridaii \\
\hline Broadfooted Mole & Scapanus latinanus \\
\hline Dittle Brown Hyotis & Myotis lucifugus \\
\hline Yuma Myotis & M. Tumanensis \\
\hline Iong eared kyotis & M. evotis \\
\hline Long-legged Motis & M. volans \\
\hline California Myotis & M. Galifornicus \\
\hline Silvethaired Bat & Iasionycteris noctipagans \\
\hline Red Bat & Lasiurus joreaiis \\
\hline Foary Bat & L. einezeus \\
\hline Pallid 3at & Antrozous paliidus \\
\hline Brazilian Free-tailed 3at & Tadarida brasiliensis \\
\hline 3rash Rabit & Sylvilaous bachmani \\
\hline Blacktailed Jackrabbit & Lepus califonicis \\
\hline Sonoma Cipmunik & Eutamias sonomae \\
\hline California Grourd Squir=el & Scemopinilus ذeecieyi \\
\hline Hestern Gray soguizrel & Scinris gziseus \\
\hline Douglas Squirrel & Tamiasciuzus coualasii \\
\hline Pocket Gopher & Momomys bottae \\
\hline Jeermann's Rangaroo Rat & Dipcdoms ieemanni \\
\hline iestern تarrest Mouse & $\frac{\text { Reithrocontomys mecalotis }}{n}$ \\
\hline Deer Mouse & Peromvscus maniculatus \\
\hline
\end{tabular}


Table I: - Contioued/

\begin{tabular}{|c|c|}
\hline Pinyon Mouse & Peromrscis =Eei \\
\hline Dusky & Neoroma Sascipes \\
\hline Califormia vole & Microrus salisoraivus \\
\hline Coyota & Canis latrars \\
\hline GraY Zox & Irogron ginereoargenteus \\
\hline 31ack Jear & Orsus mericanus \\
\hline Riscail & 3assarisess astu=is \\
\hline Raccoon & Procron 10tox \\
\hline iongeailed Heasel & Wustela Énata \\
\hline Jaçer & Taxidea Faxas \\
\hline Spotted Skank & Spilogale putorius \\
\hline St=iped skurk & Mephi=is neprizis \\
\hline Zuma & Eelis soncolor \\
\hline Babeat & Lynax ans \\
\hline tule seer & Cdocoileus benionus \\
\hline
\end{tabular}


Table 12 Reptiles in the Study Area

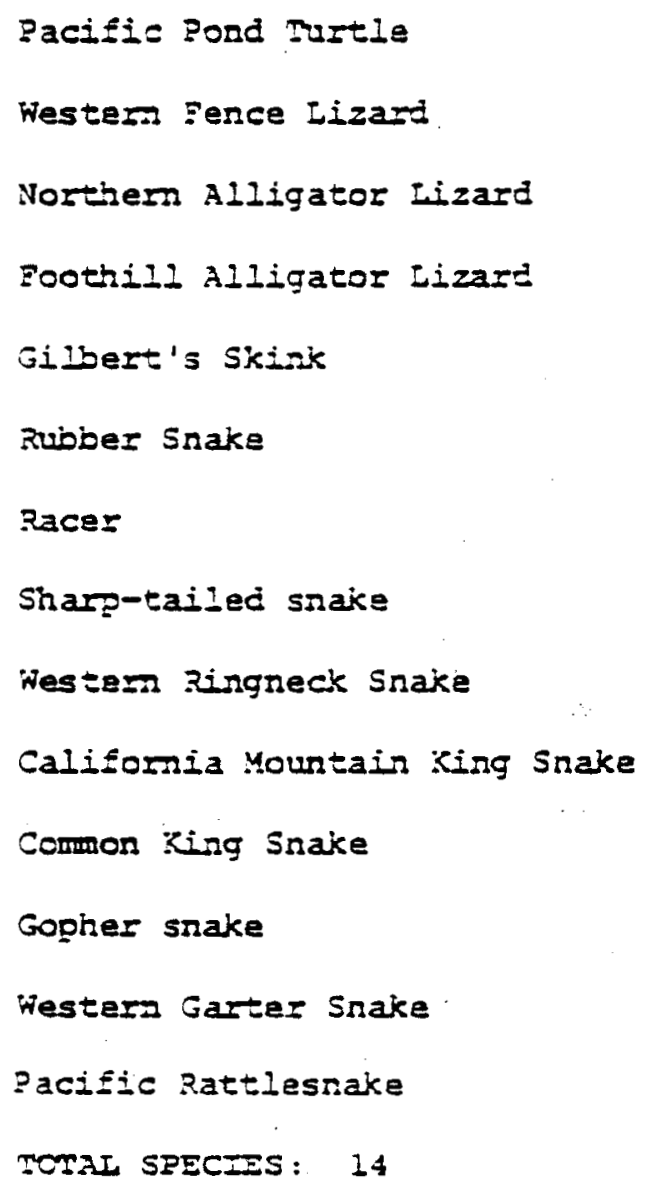

Qlemmys marmorata

Sceloporous ocsidentalis

Gerzhonotus soeruleus

G. multicarinotus

Eumeces giverti

Charina botzae

Coluber constictor

Contia Eenuis

Diadophis amacilis

Lamoropeltis zorata

i. getulus

Pituopis catenizer

Thamroonis so.

Crotalus viziais 
Tale 13 Ampitians is the stucty irea

Califormia Slender Salamander

Calisoraia Newe

Rough-skisned stewt

Paci三̇e Giant Salamander

Escioscholtz's Salamander

Azboreal salamander

3lack Salamander

Western Toad

Pacisic Inoe syog

Yellow-legged I:og

Red-legged $5=0$
Batracioseps atteruatus

Taricia Eoresa

2. granulosa

Dicamptocion ensatus

Ensati=a escisciol=zi

ineides bagingis

A. EIarigureszess

Bufo joreas

Eyla zegilia

Rara soy lei

Rana aurora

TOPAL SPECIES: 11 
comunities as a result of extensive industrial, residential or agricultural development of the area would probably threaten the long-term survival of the species as it clearly has throughout soutiern California, where Peregrine Falcons now appear to be virtalily extinct as resicent birds. 
3ECOMIENDATICNS

The resules of this sticy and cbserrations of the preceeding year indicate that encangered hrerican Peregrine Ealsons have sucsessiuliy ge-estabisined a tracitional sesting sile at $M t$. St. Helena and the habitat appears to be optimal at the present tire, because naximum Ieprocuctive success was boserved dofing the past =wo breeding seasons. Altough jo precise exrent of the Soraging sarce sould nor be detalmied Hrough visual wacking nethods mere were indications hat foraging efficiencl was high anc continced geproductive sucsess is assured as Long as the jiotic itrersify of the soraging habizat gemains intacs. Jowever, extensive hum alterations of the babitat cocld thzoeten the long-teg surripal of this encangered species as it clearly has in soutinern calizormia where breeding Peregrizes are sow on the bri-k of extiction. In orjer so aake a thorough assessment of the dependency of tiese bijeds on foraging habitat is the known Geotheral kesourses Area, and the jate of liedgling ofispring, zadio-teiemety data is zoquired. Thersiore, the author emphaticaily zecomends the imediate initiation of the lhase if Iisld stury to accomplish these bjectives bu=isg te 1979 braedico season. 
Bent, A. C. 1938. Life Histories of North imerican Bizds of ?zey. Smitisonian Institution G. S. National Museum Bulletin 170. 482 pp.

Cade, T. V. 1960. Ecology of Peregrine and Gyrfalcon Populations in Alaska. University of California Publications in zoology $63: 151-290$.

Enderson, J. H., D. G. Roseneau, and I. G. Swartz 1968. Vesting PerSormances and Pesticide Resicues in Alaskan and Yukon Peregrizes in 1967. Auk 85: 683 .

Herman, S. G., M. I. Kizven, and R. N. Risebrough. 1970. The Pezegrine Faleon Population Decline in Calisonia $I$. A Prelininary Reriew. Auduton Fiele Nores 24: 509-613.

Hunt, घ. E. 1975. Unpublished repor:: Obsezvations on the Delineation of critical Habitat at a Norizern Calizornia Pereczine Faleon Nesting Territory.

Kirren, M. N. 1977. Jngublished report: a Pzelininary Study of the Peregrine Falcons in the proposed Geothermal Develocment Area, Sonoma Countr, California. Submitsed to Repubile Geotherma I, Inc.

Poole, E. Z. 1938. Feights and Fing areas of Yorti american 3izds. Auk 55: 511-517.

Wenzel, . 0 . and $\Xi$. C. Gheen 1975. Unpublished report: Identification of Some Aspects of Crivical gabitat at Two Persgzine Faloon Nestind Territories in Nortien Calisornia.

White, C. M. 1974. onpublished zeport: Junting Range of a sreediag Peregrine Falcon on Franklin BlufE, Sacavanizktok River. Submiteed to U.S. Dept. of Incerior Fish and Nilcilfe Service, Anchorage, Alaska.

and T. J. Cade 1975. Onpublished report: Lone Term Trends of Peregrine Populations in Alaska. 
ACONOWLELGENESTS

I wish to express ay grarizude to momas Cordill, of He sonoma count? Planing Depazent, who patiently provided adri-is=ative support and ceative insight hroughout tie conceptal stages of plangirg the stady program and the execrion of the phase I fisld stucy. I also thank the members of the sticty exumittee and researth team: James Inderson, thomas

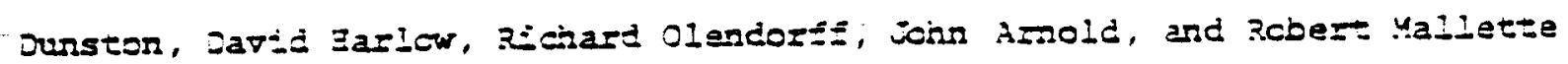
sor goidance and advice in the planning of the study. A special ject of

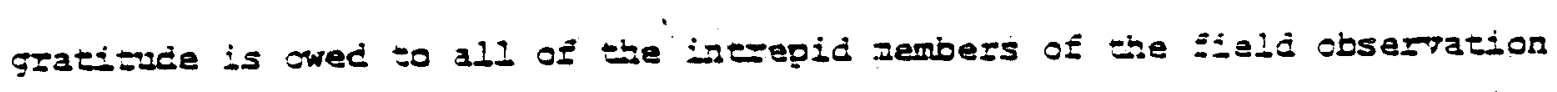

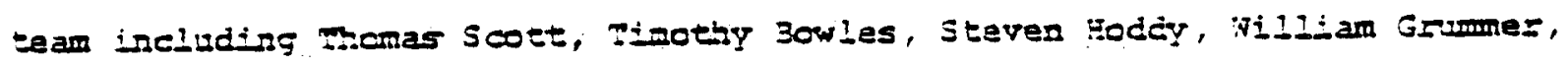

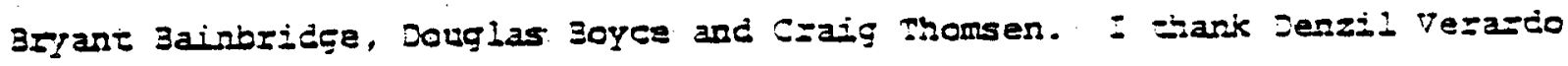
sor assisting the siald parfi in eorntess ways. 
APPENDIX A

i

APPENDIX 
ii

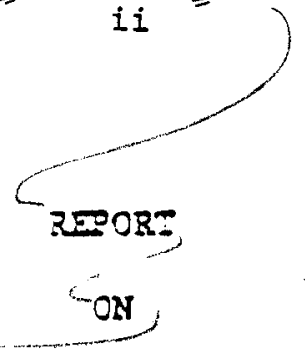

A PREIIIIARY STUDY OF ZEE PEREGRIVE FAICONS DV TEE ?ROPOSD GEOTEERMAL DEVICLRIENT ARE: SONOMA COUNTE, CALEFORYIA

Submi=zad :0

REPUELIC GEOTHERKAI, IUC. Li323 E. SLALSON AVE., SUTTE : SANIA TE SPRITGS, CALIFORNIA

and

OTEER TITZRESTED ?ARIIES
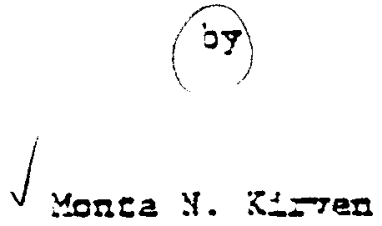

Sciool of Envtronmental Seudies and ?lanzing

(170) Soroma Stace Coligge

$$
\text { Rohnert ParR, CA }
$$


APPENDIX A

iii

\section{ABSTRACF}

In the sunmer of 1977, a kield study was undersaken to gonitor the foraging activifies of a Eamily of American Peragrine Ealcons nes ing in the racinify of the Republic Gathezal-McMicking Leasenold, Sonona Coun, Califoria, fl an effort to derermine tie relative importance of the 3rtggs Creek dratrage habitat within the Leaseiold. Obserrational data consistiag of visual compass bearings and triangulations of iligit patrerns of the Ealcons, and nest site activittes, were interpreted to suggest that approximately one-thifd of the foragiag flights were to the direction of the 3 iggs Creek drafnage. Izansect bird population censuses taken jy Leiefer and Melier in the ripartan habilat rere comoared to prey remains coliected at the falcon eyrie and sicwed a 23 jercent

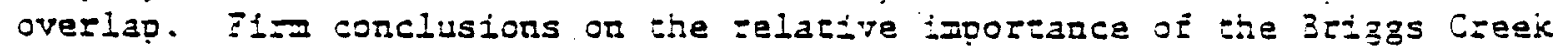
habitat to the Ealcons dufing the ctitical teproductive peziod could not be drawn because the daca were not surficiencly conprenensive. The prin-

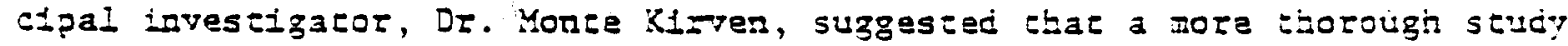

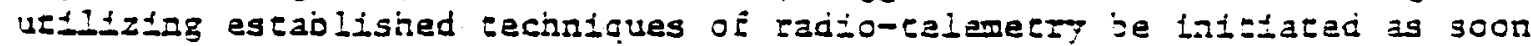
as possible so that nore defiziefve statements san be aade about tie inportance of the 3 razgs Creek habitat and tie potential lupact of geothernal development to the survival of the Peregrige ialcons. 
conranss

\section{Page is}

\section{DITRODUCIION}

Statement of the ?toblem . . . . . . . . . . . . . . . 1

objecsives . . . . . . . . . . . . . . . . . . . . . i- 2

\section{WEDS}

Toe seudy drea. . . . . . . . . . . . . . . . 3

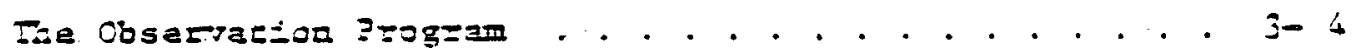

Idencificasior of leay spectes . . . . . . . . . . . . . 5

sesul=s . . . . . . . . . . . . . . . . . . . . 6-is

JISCISSION . . . . . . . . . . . . . . . . . . . . . . . . . . . . . .

ACSTOWDGEDES . . . . . . . . . . . . . . . . . 13

IDERALUE CIDE . . . . . . . . . . . . . . . . . 19-20 


\section{INTRODUCIION}

Stafement of the ?=00iem

The population decine of the peregrine falcon in lorth tmertca has been well-documented during the past thirgy years and the spectes is now considered ta danger of extinction by the U.S. Department of Intertor (1). In the eastem inited States, where aporoximately 300 pafrs of ?eregzines once sested, the sesident populatien has been ratuaily extinct for over a decade (2). Fie extinction process, winici has been at:rujuted to son-

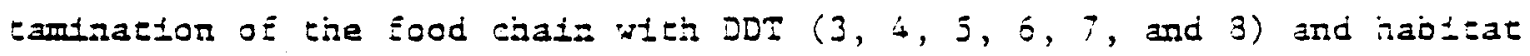
encroachment by nan, was repeaced in the Rocky Houncatns, where the jreeding population is now reducec to a fer sterile paizs $(9,10)$. In CaijE-

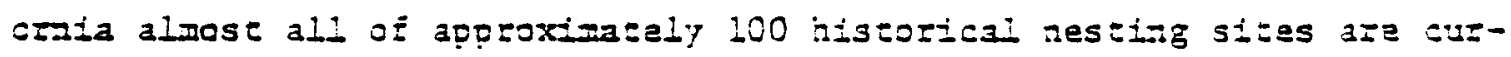
rently unoceupfed (12), but there is a zemanc population in the nortien pars of the state at the tine of this rtting (12, 13, and 14). Indeed, Exom my own obserrations, and those of others, it can be concluded that one of the last strongholds of the spectes jetiean the Canadian and Yer-

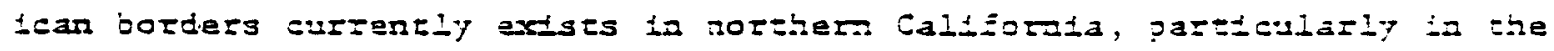
proposed geochermai deveiopmen areas of Sonoma, Napa, Lake and Kencocino coursiss. In these areas the population is stili produciag young, in contzast to the sifuation elsewinere. The question of fminent fmportance fs: so what extent wil such development afjecs the continued suritial of tie Peregrane Ealcon?

Obtectzves

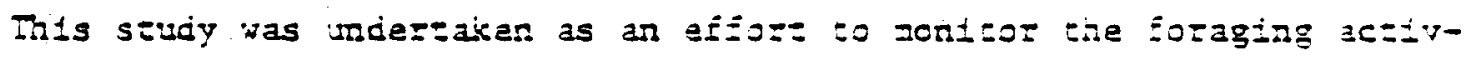

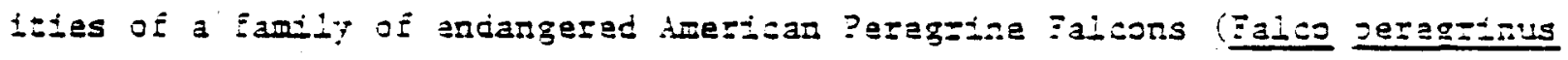




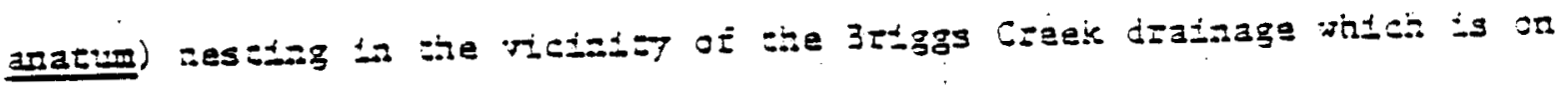

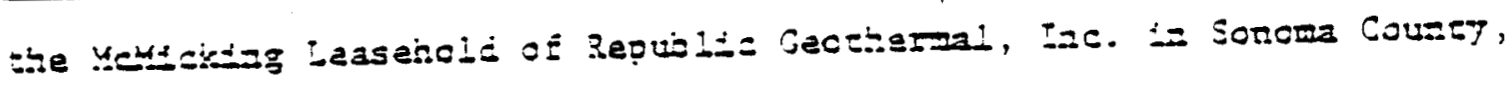
Calfiorsia.

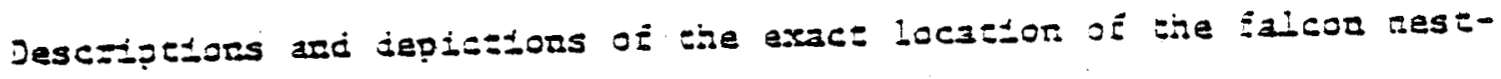

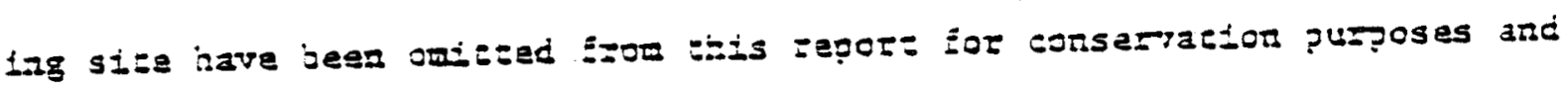
are deemed superfluous to the objectives of the study. It was hoped that the gesult=3 of this study, and the simileaneous estinates of population

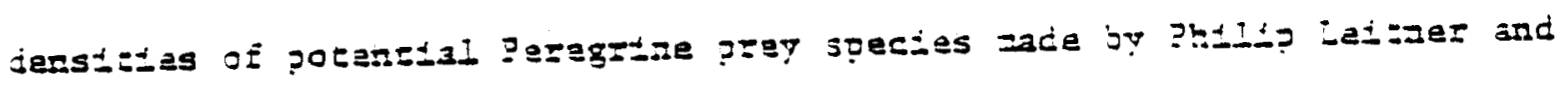

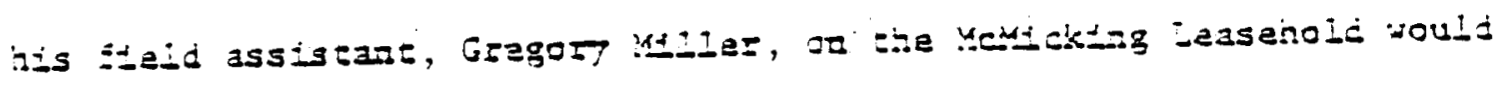

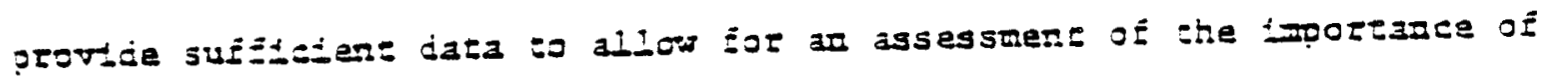

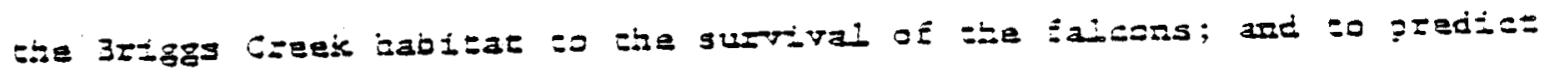

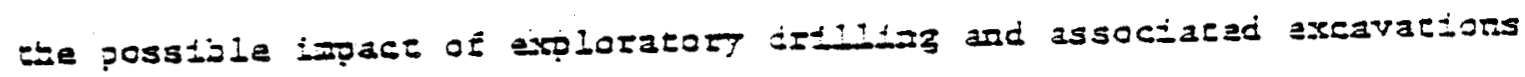

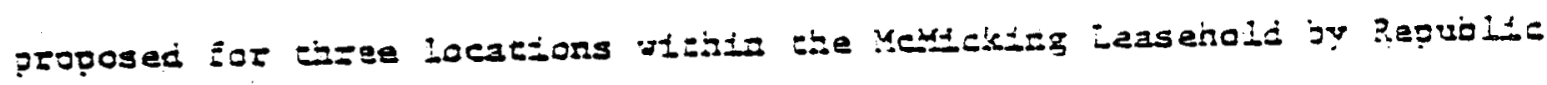
Georierad. 


\section{The Srudy Area}

The study area is characterized by rugzed, fourtatrous cerzain heavily Eorested wis Douglas-sir (Pseudotsuga menziesif), Ponderosa

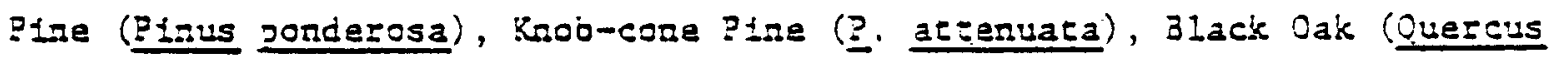
Kelloggi), Coast Live Oak (Q. agrifolia), Oregon Oak (Q. zargana), Madrone (Arbucus Jenztesti), Califoria Bay (Tnielluiaria californica), Calfioria Buckeye (Aesculus caltsoraica), and a diversizy of other liees, singibs, grasses and herjaceous species. The pixed evergreen sorest is inundarad With elements of the chaparal comunizy consisting of uised stands of

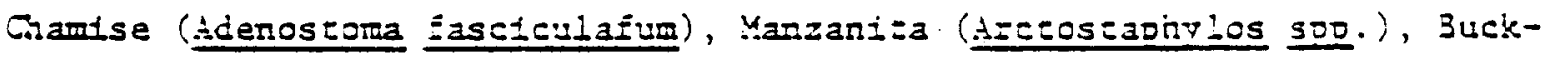

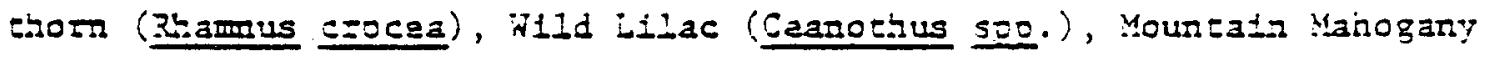
(Carcocarpus beculolies), and a vartety of associared species. Fine ingh, dense vegefarton and uneven terrato of the study area preserted obstactes for Tisual observation of the falcons.

The Obserjation?:Og:am

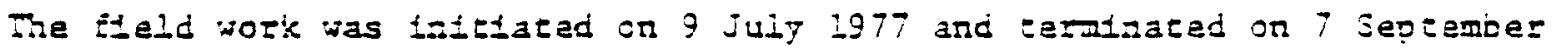
of the same gear. Jurtigg the pertod of lo july to 21 August, contaluous observatzons were race on the Soragiaz activities of tie ialcons Szom seiectad vantage poines in the veluley of the resting sise by a minimum of iro expertenced full-tine ooservers. Observers were relieved at various intervals

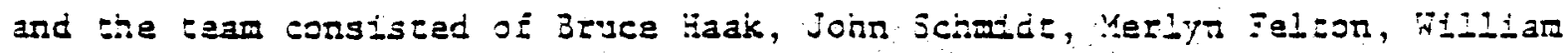
Grumer and gyselz. The bulk of the josergations were nade jy laak and Schidit. Iizochy 3owles, wio was assigned to sonduct surreiliance of the ey=ie by

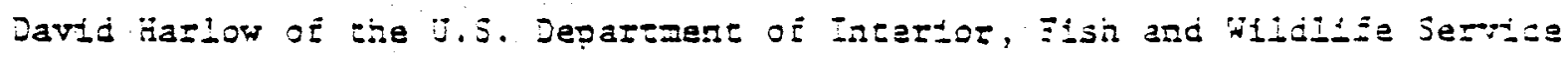
as a part of the ?acticic coast ?eregrine Eaicon lecovery leam ?:ogram, ias 


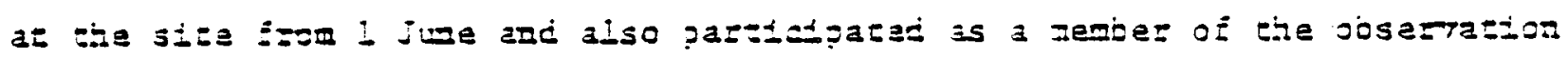

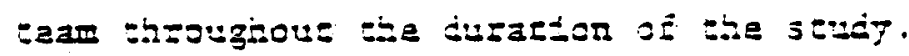

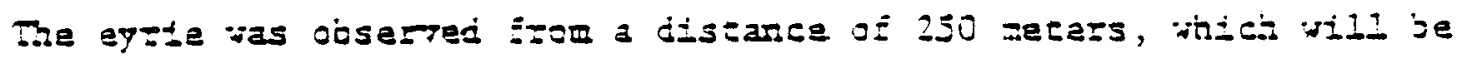

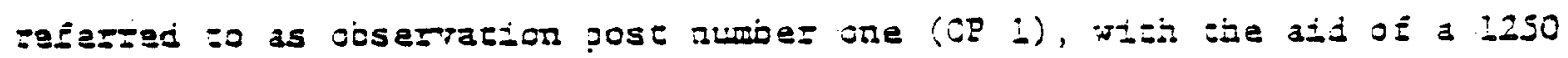

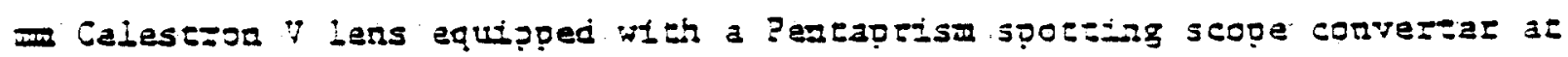
50 and 100 powers. The acile falcons could be seen Egor this vangage poi=t

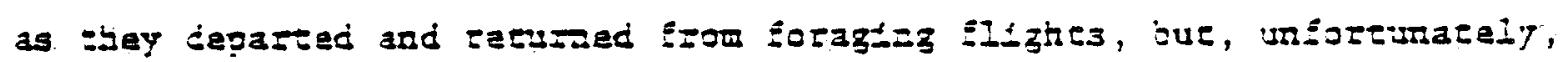

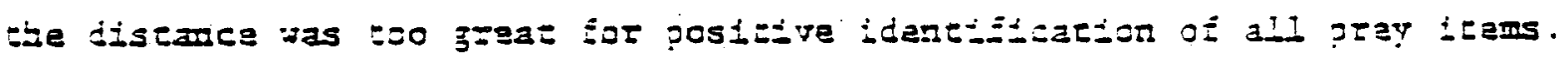

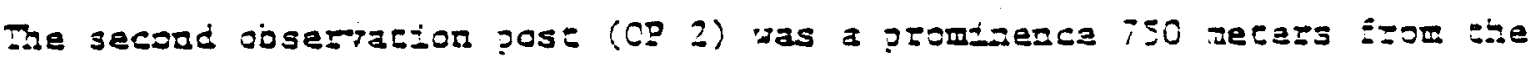

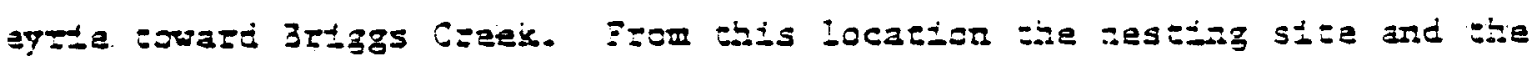

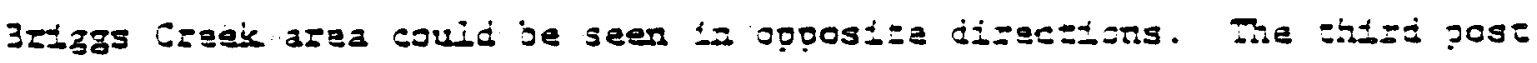

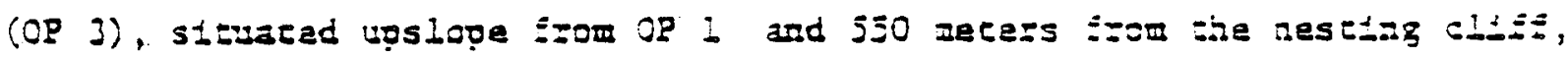

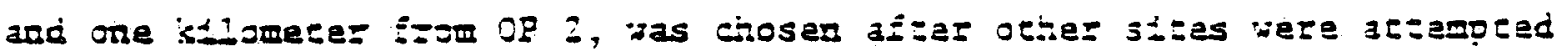
and Eourd to be unufiable for coortlared oosergatons.

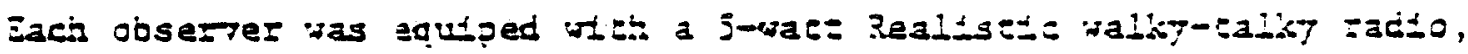

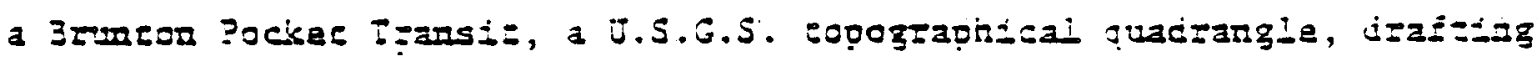

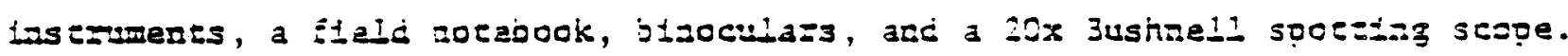

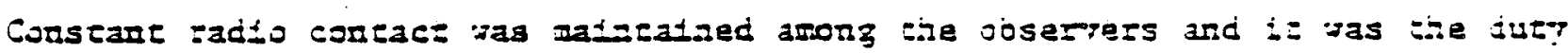
of the obserper at $O P$ I to alert the ocher soserters 30 OP 2 and oP 3 fitien

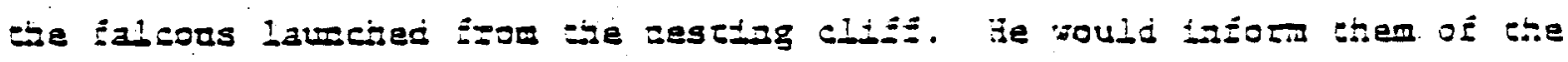
flight path of the Salcen(s) and everyone would actemet to ploc the compass

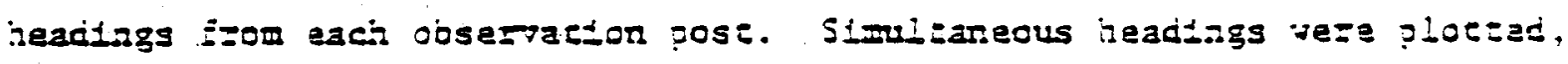

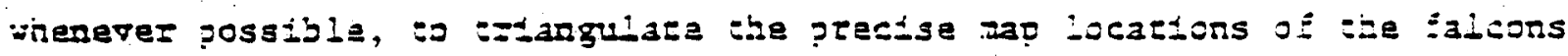

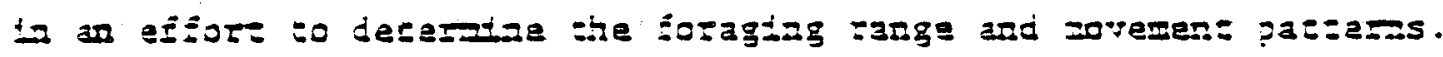


Idencisication oj ?zey Soecias

Thorougi fdentí_cafion of pray species could not be accompinsined Erom any of the obserration posis because of the $z$ reat distances izvolred, so on 21 August, long after the young falcons had Elecged, Bruce iaak and I (Monte Kifren) sapelled down the face of the resting clfft to collect prey rematas from the eyste hole and along the base of the cliff. Rigren and haak were assisted in the climo by Denzil Verardo and il111am Grumer, Fino provided equipment and frdfrect aid of belay. Lacer, Joris Scinids and I identified the proy remaizs and compiled a list of spectes. Ingotiy 3owies prepared a sumary of his ooservations on the foraging activitues of tide falcons as seen Ezom OP 1 Erom 1 juse to $17 \mathrm{july}$, jhflh provided some guantisacive data on prey items brought to the nest jy the falcons. 


\section{RESULZS}

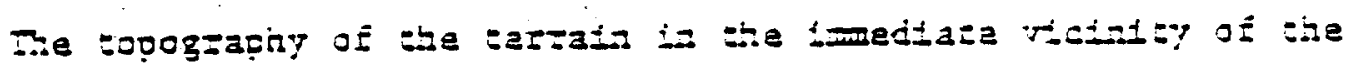

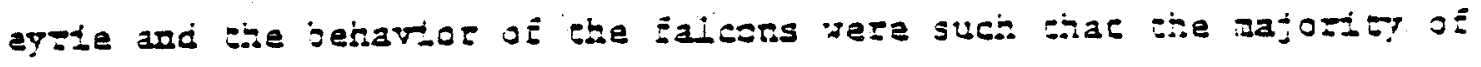

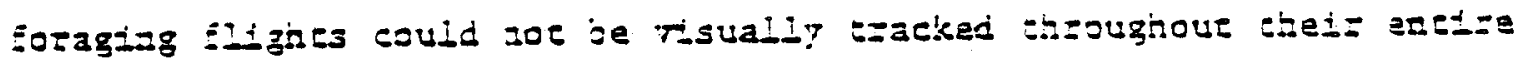
courses. I= lose cases, however, at least a porston of eaci fligiz could be observed, and a cotal of $7 I$ difectonal bearings zere plocied

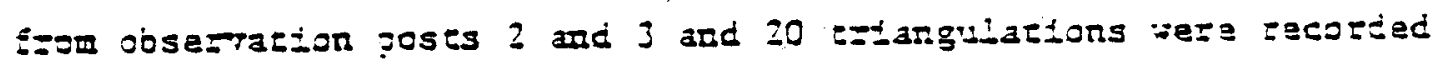

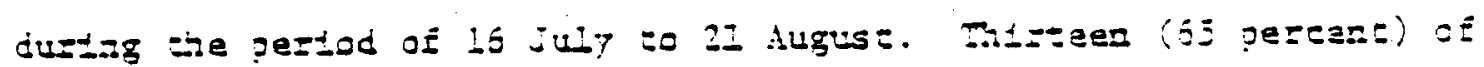

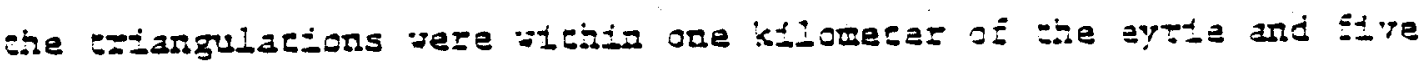

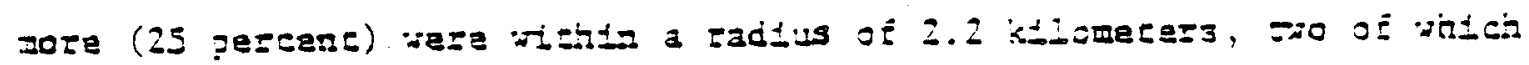

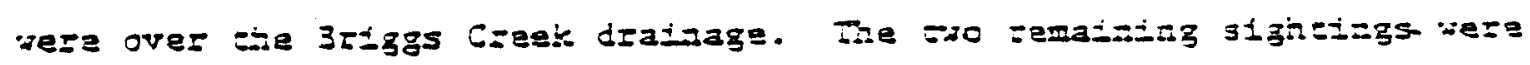

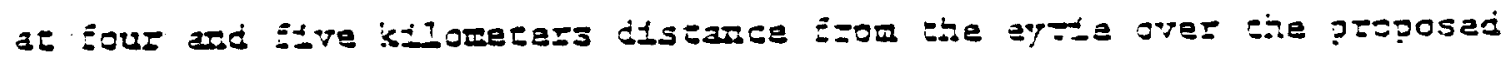

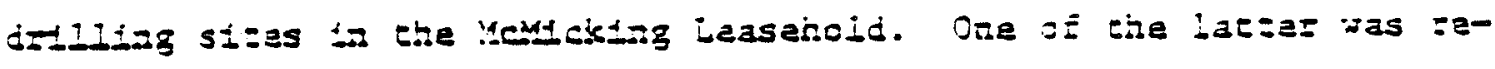

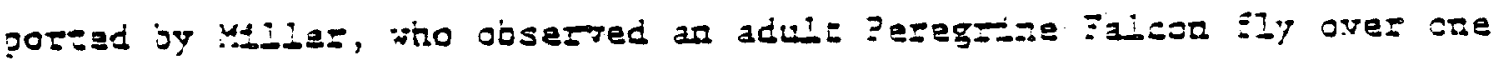
of the pocencial prep spectes transecrs. Fe sotad that the falson ras

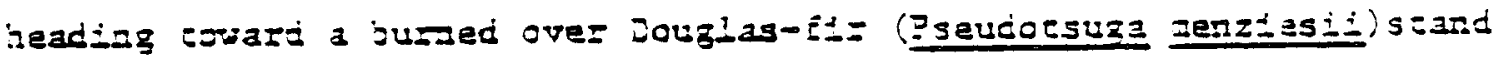

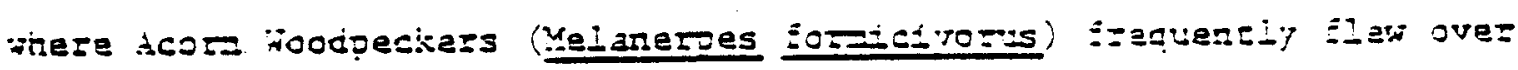

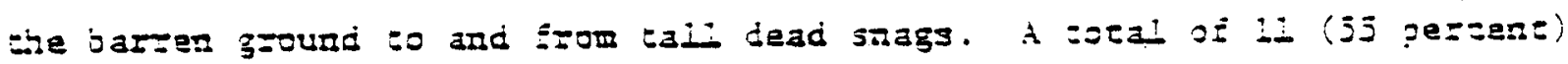

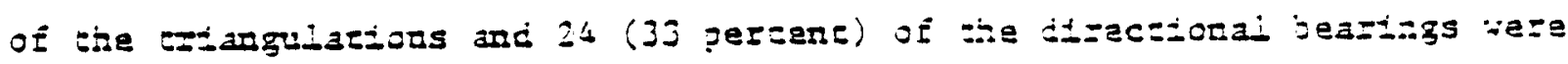
is the jezeral dizection of tie 3riggs Cieek irea.

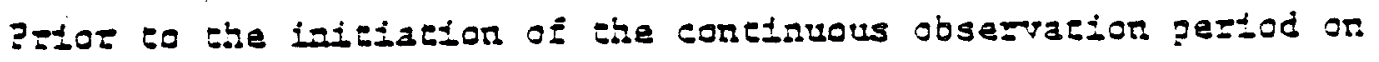

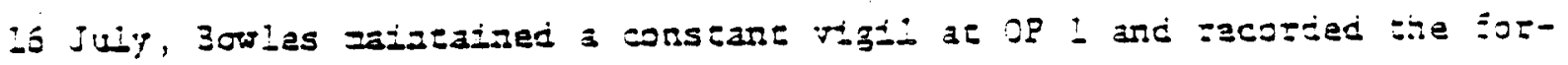

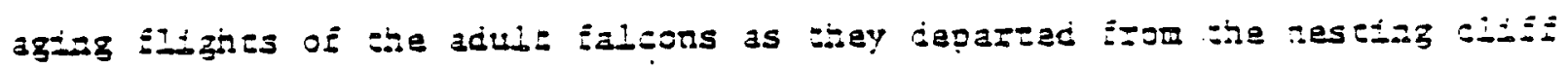

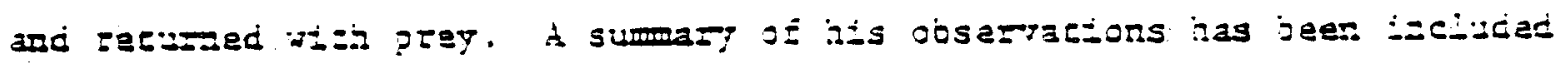

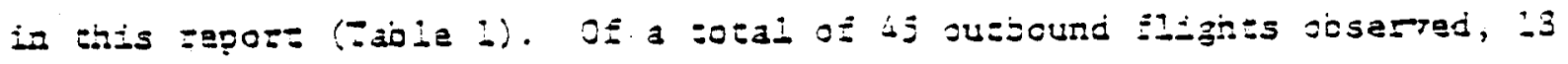

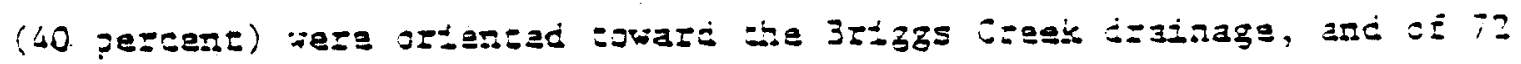




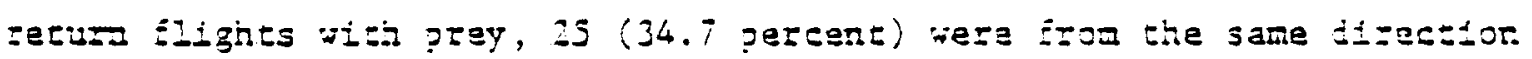
(Zables 1 and 2$)$.

Table 1

Peregrine Baicon foragiag Eİjinto from

eyrie as seen from obsarration post aumer one.

\begin{tabular}{|c|c|c|c|c|c|c|}
\hline DAIE & $\begin{array}{l}\text { TRE } \\
\text { OUT }\end{array}$ & SER & $\begin{array}{c}\text { TOWARD } \\
\text { 3RIGGS CR. }\end{array}$ & $\begin{array}{l}\text { TIYE } \\
\text { BACE }\end{array}$ & $\begin{array}{c}\text { EROR } \\
\text { 3RIGES CR. }\end{array}$ & 209 \\
\hline $5 / 1$ & & $\mathcal{O}^{7}$ & $\ldots$ & 1620 & $x$ & Rodent? \\
\hline$"$ & 1750 & $"$ & $x$ & 1830 & $x$ & No ID \\
\hline $6 / 2$ & 1251 & $"$ & & 1540 & $x$ & $\operatorname{Smal} 31=d$ \\
\hline$"$ & 1653 & " . & $x$ & - & & So ID \\
\hline $6 / 3$ & 0834. & $"$ & & 1057 & & Smail 3ird \\
\hline$"$ & 1136 & 1 & & 1259 & & Quati ? \\
\hline $6 / 4$ & 1225 & $"$ & $x$ & 1500 & & Domes $= \pm c$ Pizeo \\
\hline $6 / 5$ & 1225 & $"$ & & 1512 & & Dio \\
\hline $6 / 7$ & 0753 & $"$ & & 1630 & $x$ & No D \\
\hline $6 / 10$ & - & $"$ & 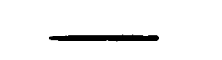 & 1253 & & Elycaccher? \\
\hline $6 / 11$ & 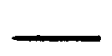 & $\because$ & 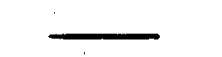 & 1525 & $x$ & Dove \\
\hline $6 / 12$ & $\longrightarrow$ & $"$ & - & 1255 & $x$ & Sma11 3i=d \\
\hline 11 & 1500 & $"$ & $x$ & 1700 & & So ID \\
\hline $6 / 13$ & 1350 & $"$ & & 1445 & & Smal1 $31=d$ \\
\hline $5 / 14$ & 2014 & $"$ & & 1050 & & So $D$ \\
\hline " & 1700 & " & & 1817 & & " \\
\hline $5 / 15$ & 0925 & $"$ & & 1015 & & $"$ \\
\hline $6 / 16$ & 1053 & is & & 2117 & & $\because$ \\
\hline$"$ & 1448 & $"$ & & 1620 & & Smal1 $31= \pm$ \\
\hline $6 / 17$ & 1355 & $"$ & & 1530 & & No $D$ \\
\hline
\end{tabular}


Table l cons=anued

\begin{tabular}{|c|c|c|c|c|c|c|c|}
\hline DAEE & $\begin{array}{l}T T \sqrt{S} \\
O L=\end{array}$ & $s \equiv$ & $\begin{array}{c}\text { EOTVARD } \\
3 R I G U S \text { OR. }\end{array}$ & $\begin{array}{l}I_{2}=5 \\
3 i C X\end{array}$ & $\begin{array}{c}\text { EROM } \\
\text { 3RIGOS 6R. }\end{array}$ & S.R? & \\
\hline $6 / 19$ & 2910 & 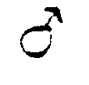 & & 0950 & $x$ & Dove & \\
\hline " & 1050 & $"$ & $x$ & - & & - & \\
\hline $5 / 20$ & $\longrightarrow$ & $"$ & - & 0925 & $x$ & $\operatorname{san} 11$ 3i=0 & \\
\hline " & 1204 & $"$ & $x$ & 1315 & & $"$ & \\
\hline $5 / 22$ & $\longrightarrow$ & $"$ & - & 1815 & & 30. D & \\
\hline $6 / 23$ & - & $1 "$ & - & 1028 & $x$ & Dove & \\
\hline $5 / 24$ & 1213 & ip & $x$ & 1436 & & Dי & \\
\hline $6 / 25$ & $\longrightarrow$ & $"$ & L & 1258 & $: x$ & Sexa1: $31=0$ & \\
\hline 5i26 & $1+30$ & "r & & 1436 & & Mrcarsier & $?$ \\
\hline$"$ & - & $"$ & - & 0613 & . & DI & \\
\hline $5 / 27$ & 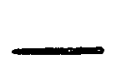 & $"$ & 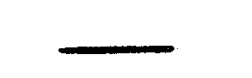 & 0855 & & Dove? & \\
\hline$"$ & 1044 & $\underline{0}$ & & 1044 & & 3and-cailed & ? 5 geor \\
\hline $3 / 29$ & & $d$ & 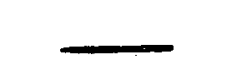 & 1307 & & Dove? & \\
\hline $6 / 30$ & 1532 & 19 & $x$ & 1310 & $x$ & $\operatorname{sir30} 31=1$ & \\
\hline $7 / 1$ & $\longrightarrow$ & 19 & - & 0725 & 3 & "..." & \\
\hline$"$ & 0910 & $"$ & $x$ & 0940 & $x$ & Jove & \\
\hline$"$ & 1015 & $"$ & $\mathbf{x}$ & 1245 & $x$ & Smail $\exists i= \pm$ & \\
\hline $7 / 2$ & 0700 & 12 & & 0719 & $x$ & $"$ & \\
\hline$"$ & - & $" 1$ & & 0849 & & Dove & \\
\hline 18 & $\ldots$ & 19 & & 0946 & & Ter? Smald & $31=0$ \\
\hline$"$ & 1237 & " & & 2415 & & $3 l a c k j=1$ & \\
\hline $7 / 3$ & 1355 & $"$ & & 1443 & & Larze $31=4$ & \\
\hline$"$ & - & $"$ & $\longrightarrow$ & I51 & 3 & Se $=$ & \\
\hline $7 / 4$ & 1230 & $"$ & & 1315 & & 3lacirji=ذ & $?$ \\
\hline
\end{tabular}


Table 1 coneinued

\begin{tabular}{|c|c|c|c|c|c|c|}
\hline DAIE & $\begin{array}{l}\text { IInE } \\
\text { out }\end{array}$ & SES & $\begin{array}{l}\text { TOWARD } \\
\text { 3RIGGS CI }\end{array}$ & $\begin{array}{l}\text { IIEE } \\
3 \perp C K\end{array}$ & $\begin{array}{l}\text { EOOM } \\
\text { 3RIGGS CR. }\end{array}$ & ZRE? \\
\hline $7 / 4$ & & $0^{7}$ & - & 1410 & & Dove? \\
\hline$"$ & $\longrightarrow$ & $"$ & س & 1359 & & Band-cailed Pfgeon \\
\hline $7 / 5$ & $\longrightarrow$ & $"$ & 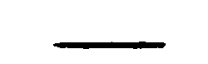 & 0800 & & No \\
\hline $7 / 6$ & 0855 & 9 & & 1020 & & Dove ? \\
\hline 18 & 1357 & $\sigma^{7}$ & $\mathbf{x}$ & 1508 & $x$ & Mediun-stzed 3izd \\
\hline $7 / 7$ & $\longrightarrow$ & $"$ & - & 2152 & & No ID \\
\hline$"$ & & $\because$ & - & 1501 & $x$ & DI \\
\hline$"$ & $\longrightarrow$ & $"$ & & 1815 & & Small $3 i=0$ \\
\hline $7 / 3$ & 1136 & $"$ & & 1210 & $x$ & Dove \\
\hline$"$ & & " & & 1308 & & Smal1 $31=d$ \\
\hline$"$ & & $" 1$ & & 1356 & & $1 "$ \\
\hline$"$ & 1415 & $"$ & & 1515 & & Dove. \\
\hline $7 / 9$ & 0752 & 9 & $\mathbf{x}$ & 0826 & & $\sin 1: 31=0$ \\
\hline$"$ & 1110 & $\sigma^{\top}$ & & 1137 & & $"$ \\
\hline$"$ & 1147 & $"$ & $x$ & 1315 & & $"$ \\
\hline $7 / 10$ & & $"$ & & 0950 & $x$ & " \\
\hline$" 1$ & 1420 & $"$ & $x$ & 1543 & $x$ & Dove? \\
\hline $7 / 11$ & 0955 & $"$ & $x$ & 1042 & $\mathbf{x}$ & $"$ \\
\hline$"$ & 1529 & $"$ & $x$ & 1700 & $x$ & $"$ \\
\hline " & 1529 & ? & $x$ & 1700 & $x$ & $"$ \\
\hline $7 / 14$ & & $\sigma^{7}$ & 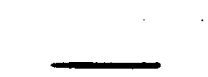 & 1020 & & " \\
\hline " & $: 103$ & $"$ & & 1106 & & 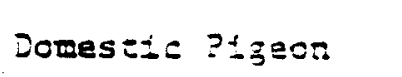 \\
\hline$"$ & & $1 "$ & & 1251 & & Pigeon? \\
\hline$\because$ & 1445 & 18 & & 1537 & & DIo \\
\hline$" 1$ & 2445 & 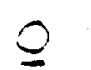 & & 1537 & & $"$ \\
\hline
\end{tabular}


Table 1 congraved

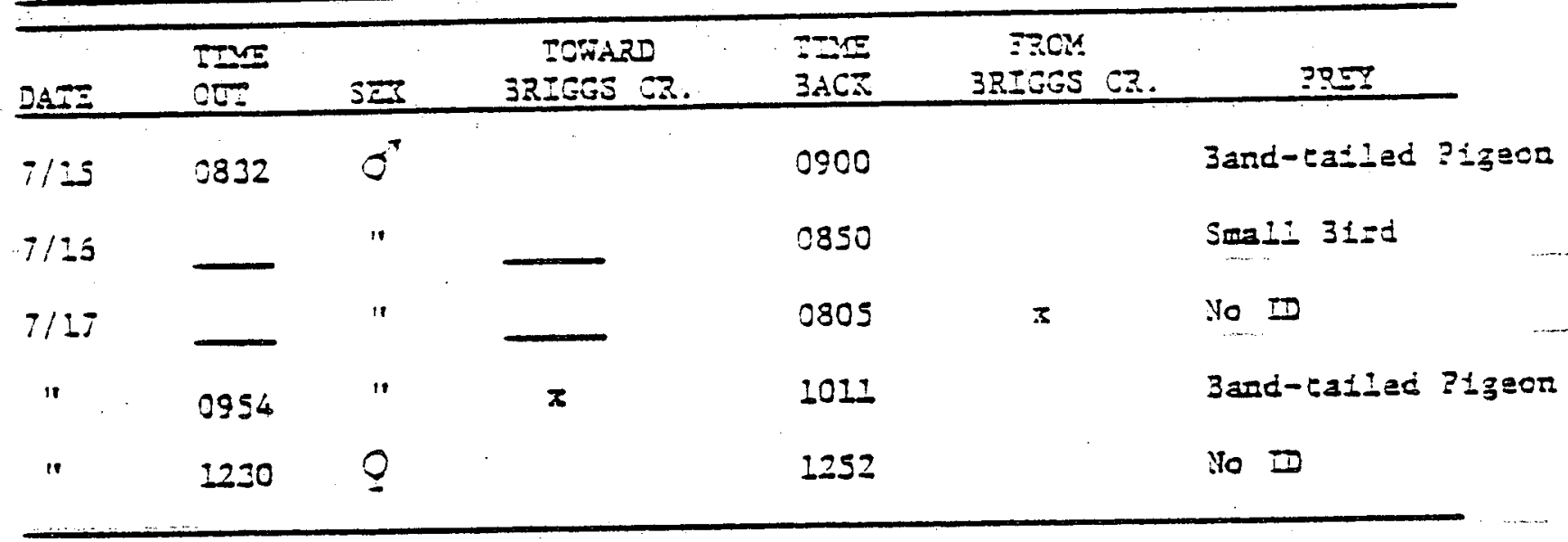

Table 2

Peragrize Faleon Eoraging

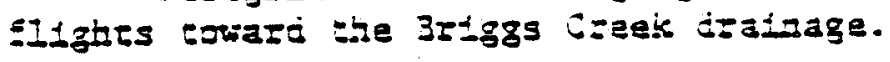

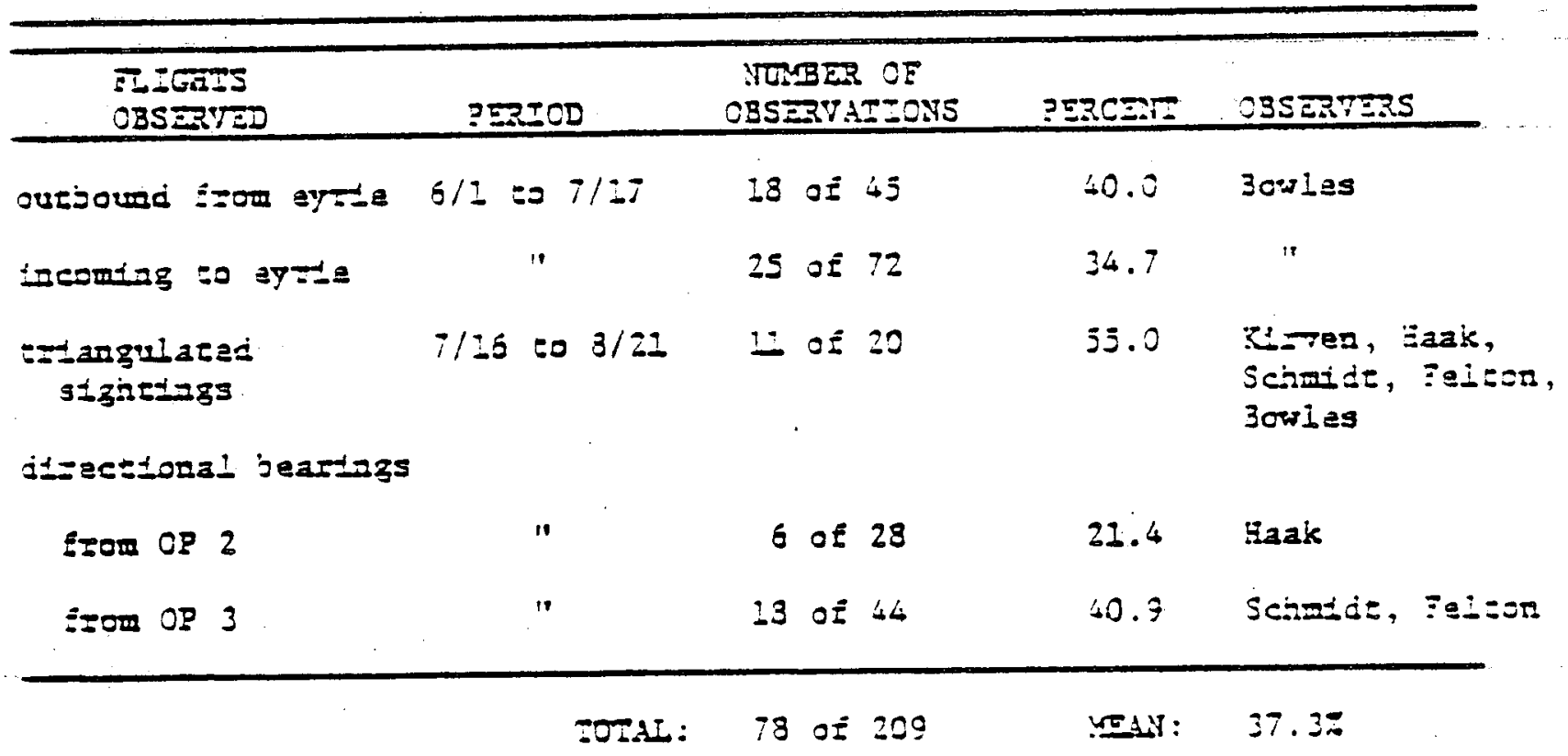


Tabla 3

Prey spectes of the Peregrane Falcons

identified from rematis found at the eyzia.

\begin{tabular}{|c|c|c|}
\hline VINIBER & SPECIES & $\begin{array}{l}\text { MORE THAN } \\
\text { ONE EOUND }\end{array}$ \\
\hline 1. & Sountain Cuatl (Oreortrx picsus) & \\
\hline 2. & 3lack-bellied Plover (Squatarola squararola) & \\
\hline 3. & 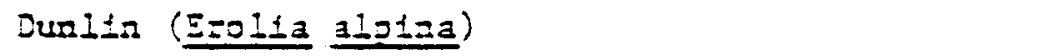 & \\
\hline 4. & Band-railed Iigeon (Columba Easciata) & $\mathbf{x}$ \\
\hline 5. & Rock Dove ( $\underline{\text { C. Bivia) }}$ & $x$ \\
\hline 6. & Yoursing Dove (Zenaldurz macroura) & $x$ \\
\hline$i$. & White-chroarad SwiE: (Aeronautas sararaiis) & \\
\hline 3. & Comonon Flicker (Calaotes.auracus) & \\
\hline 9 . & tcor= Woocpecker (Welanerses Sormiviverys) & \\
\hline 10. & Hestern kigoird (Tyanrus yez=icalis) & \\
\hline 12. & 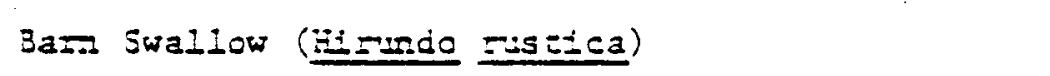 & \\
\hline 12. & CI1 IE Swallow (Zerzocieliodor pviscroca) & \\
\hline 13. & Stellez's Jay (Cyanocilia steliezt) & \\
\hline 14. & Scrub Jay (Aphelocoma coerulescens) & \\
\hline 15. & Arertcan Rooin (Eurdus migracosius) & $\mathbf{x}$ \\
\hline 25. & Searling (Syuraus rulgaris) & $\mathbf{x}$ \\
\hline 17. & Hester Meadowlark (Sturnella neglec:a) & \\
\hline 13. & Brawer's 3lackbiri (Eurnagus cyanocegnaios) & $x$ \\
\hline 19. & Red-waged 3lackisizd (Agelajus pioeniceus) & $x$ \\
\hline 20. & Black-ieaded Grosbeak (heuctieus Eelanoceoraius) & \\
\hline 21. & Towsend's Cafomiok (Eugarias gownsendi). & \\
\hline 22. & Bat (Cntzoptera, secectes unidentisied) & \\
\hline
\end{tabular}




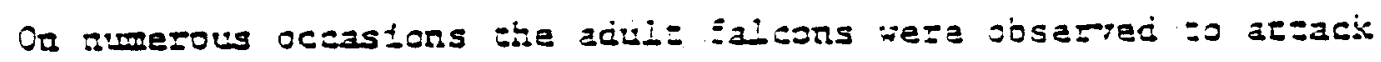

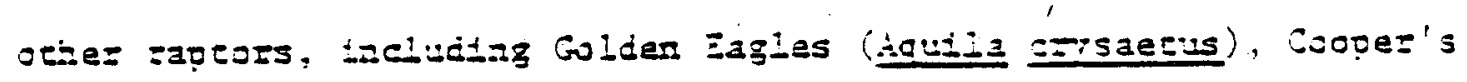

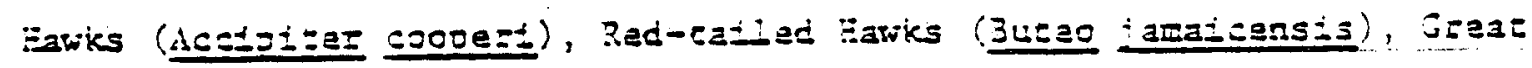

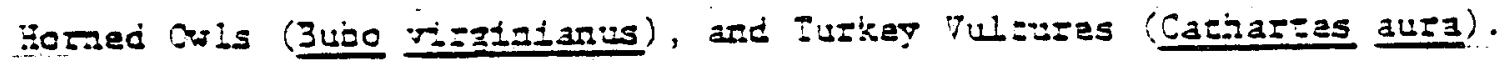
The arsacis on Golden Eagles zere aggrassive and vere ooserred so lake

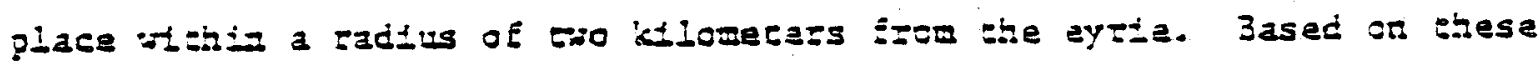
observations the tocal area of the defended eerticor? of the falloors ;as estizatad la be approxizacely 12.5 squara kílomerars.

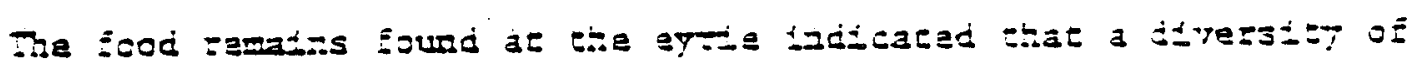

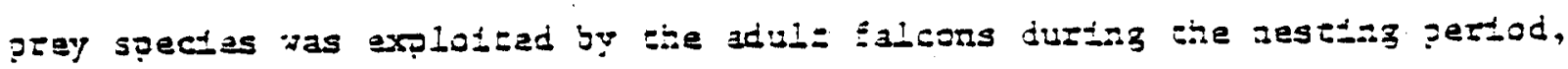

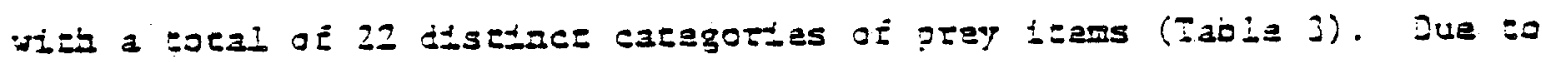

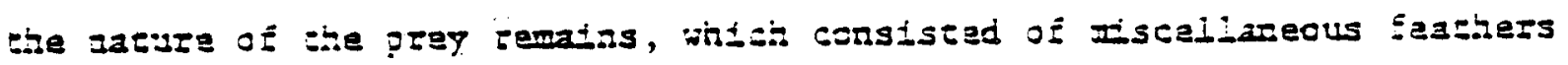

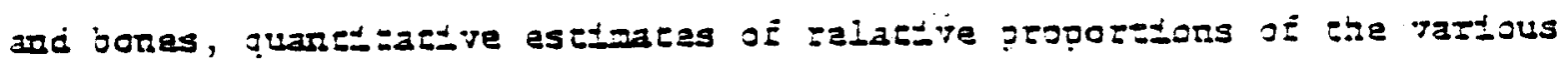

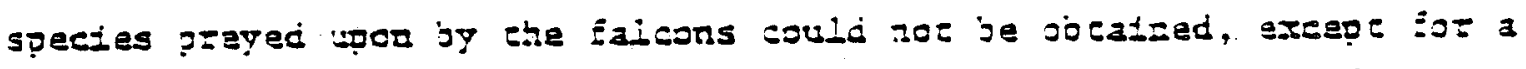

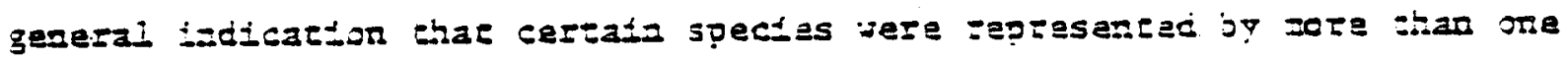

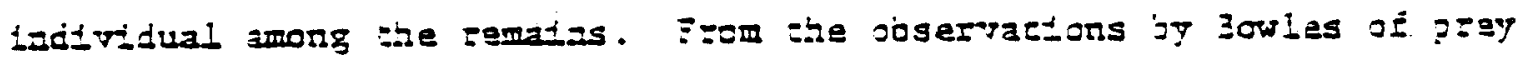

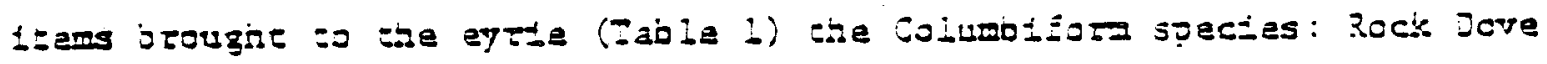

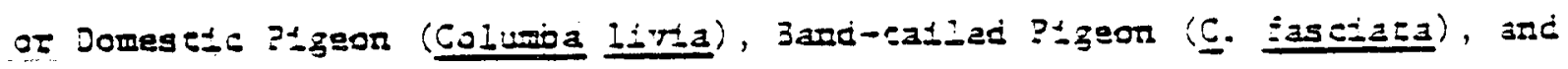

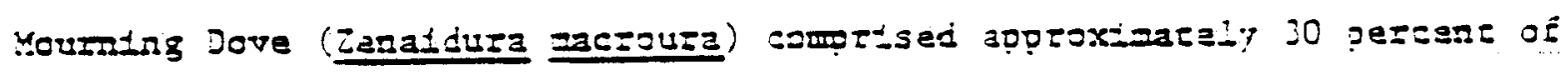

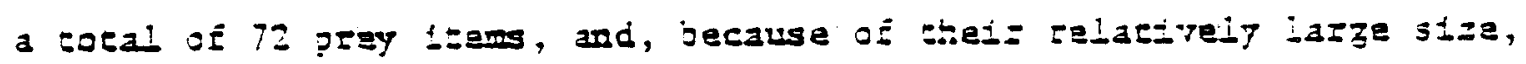

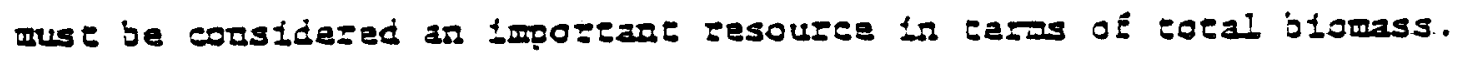

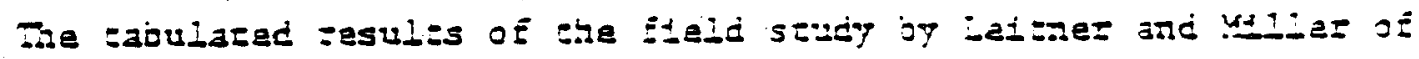

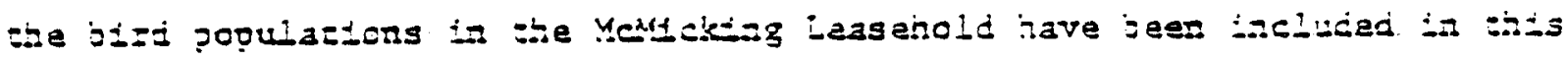
sepore for comparafite juposes (Tabie $\rightarrow$ ). 
Table 4

3ird species observed per wile of szansect on the Republic Geothermal

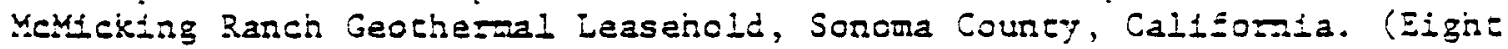
days observation per szansece, $26 \mathrm{July}$ - 19 August 1977). Numers in parentheses refer to individuals observed in lazge flocks.

\begin{tabular}{|c|c|c|c|}
\hline \multirow[b]{2}{*}{ SRECIES OBSERVED } & \multicolumn{3}{|c|}{ NUMBERS OF INDIVIDUAIS OBSERVED } \\
\hline & $\begin{array}{l}\text { Kixad Evergzeen } \\
\text { Forest, Neaz } \\
\text { Proposed Wellsice } \\
\text { One } \\
\end{array}$ & $\begin{array}{l}\text { Yixed Evergzeen } \\
\text { Eorest, Near } \\
\text { Proposed welisite } \\
\text { Two }\end{array}$ & $\begin{array}{l}\text { Ripazian } \\
\text { 3Eiggs } \\
\text { Creek }\end{array}$ \\
\hline 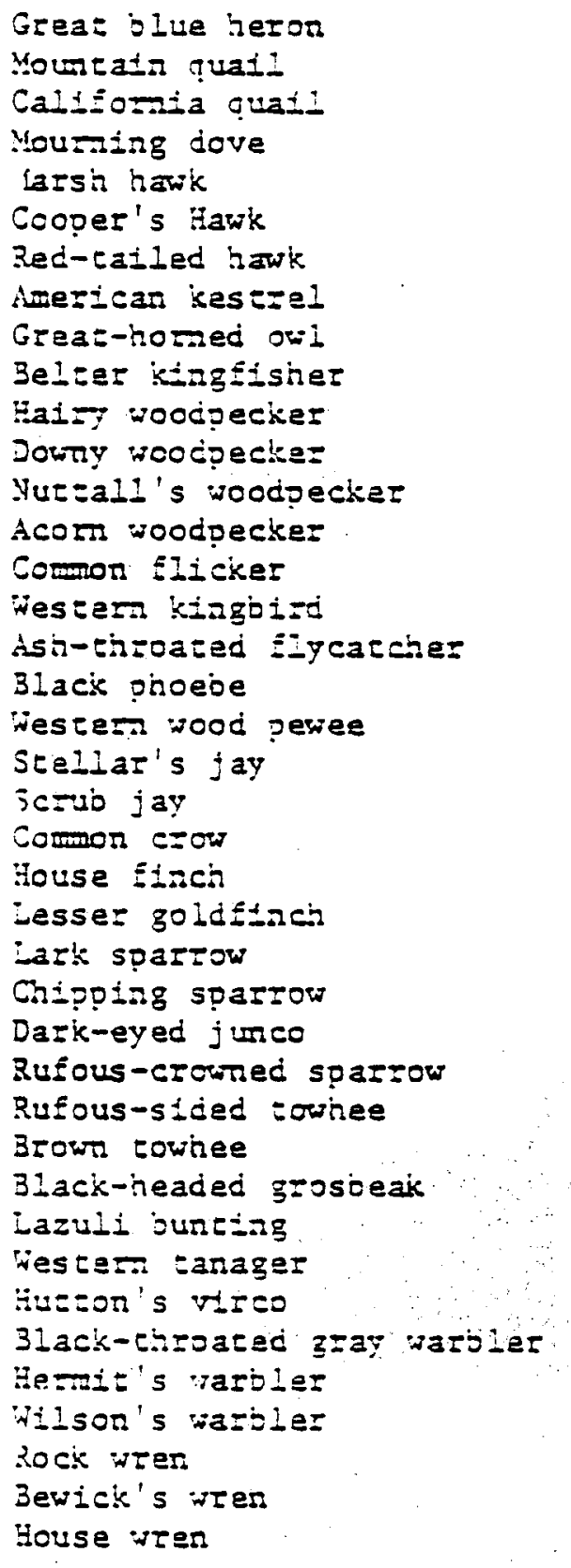 & $\begin{array}{r}5 \\
34 \\
10 \\
2 \\
24 \\
0 \\
2 \\
16 \\
4 \\
20 \\
2 \\
2 \\
2 \\
2 \\
2 \\
2\end{array}$ & $\begin{array}{r}5 \\
28 \\
75 \\
1 \\
3 \\
\\
2 \\
1 \\
3 \\
139 \\
6 \\
4 \\
3 \\
2 \\
90 \\
4 \\
\\
1 \\
31 \\
2 \\
16 \\
7 \\
5 \\
2 \\
1 \\
1 \\
3\end{array}$ & $\begin{array}{r}45 \\
1 \\
3 \\
1 \\
1 \\
8 \\
1 \\
1 \\
6 \\
83 \\
4 \\
2 \\
12 \\
41 \\
57 \\
5 \\
1 \\
9 \\
47 \\
4 \\
4 \\
25 \\
1 \\
5 \\
4 \\
2 \\
1 \\
1\end{array}$ \\
\hline
\end{tabular}


Eabie 4 son=inaed

\begin{tabular}{|c|c|c|c|}
\hline \multirow[b]{2}{*}{ STEEES OSSERTD } & \multicolumn{3}{|c|}{ ITLBERS OF TMDIVDUALS OBSERTED } \\
\hline & 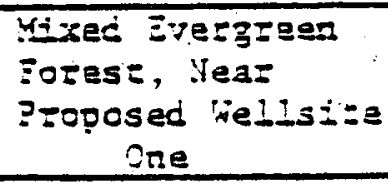 & 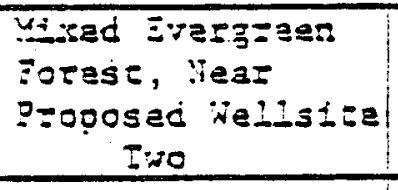 & $\begin{array}{l}\text { ijparzan } \\
35=g g s \\
\text { Creek }\end{array}$ \\
\hline 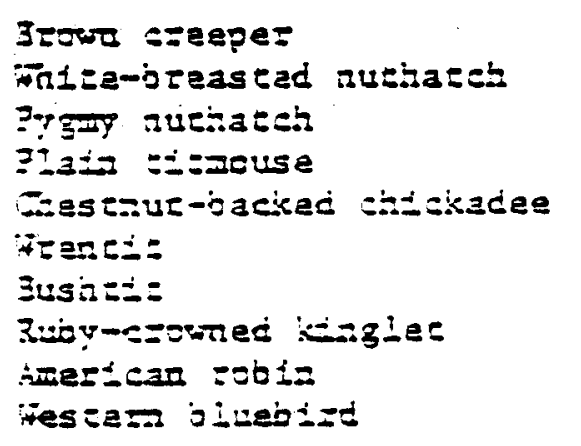 & $\begin{array}{r}4 \\
8 \\
4 \\
2 \\
6 \\
74 \\
4 \\
56 \\
3\end{array}$ & $\begin{array}{l}1 \\
15 \\
25 \\
13 \\
32 \\
10 \\
13\end{array}$ & $\begin{array}{r}7 \\
5 \\
-7\end{array}$ \\
\hline OOTIL SFE:ESS & 27 & 34 & 34 \\
\hline GOAL DOTTDUALS ?ER MIIE & 324 & 550 & 521 \\
\hline
\end{tabular}


The choonology of the oreecizg oycle vas establisted by the following obsefrations: (1) 3owies saw the acul= Eemale apparenty Seeding yourg for

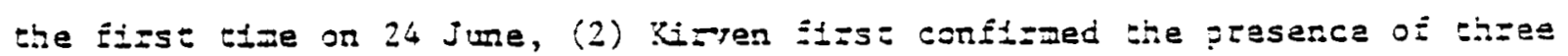
downy young, estimated to je approxizarely 20 days old, fn tie resting iole on 9 july, and (3) we all witnessed the Iledging of the fins young nale on ¿ August. By assuming an incubation period of approximately 32 days, as reporced Eor capctve Peregrines (15), and a fledging period of aporoxtmately 42 days, as oosepred at other nesting sites (15), probable dates joz sluts: Eoracton and hascilizg zere estinased (Fable j).

Table 5

The cironology of the Peragrale Eaicon breeding s7cie in 1977.

\begin{tabular}{|c|c|c|}
\hline $\begin{array}{l}\text { PROBABLE DAIE OS } \\
\text { CUICE FORUATION }\end{array}$ & $\begin{array}{l}\text { PSOBABLE DAIE } \\
\text { OF MAICEEYG }\end{array}$ & $\begin{array}{c}\text { ZIDGIYG } \\
\text { DATES }\end{array}$ \\
\hline 22 :Ly $=2$ days & 23 June $=2$ days & $4-6$ Augus \\
\hline
\end{tabular}

The young falcons Fledged on 4,5 , and 5 Auguse and someriae duzing that gertod one of the young males disappeared. An insensfve ground search by all members of the obserrafion team failed to produce evidence of tie jace of the fledgeling. On 8 Auguss the rematring male and famale bledgeltags were obserped Elyi=g around the resting blifi together. They rere often seen $\vdots=$

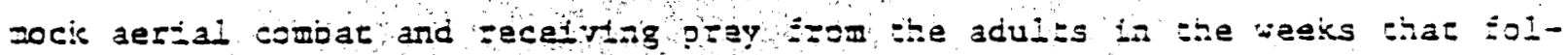

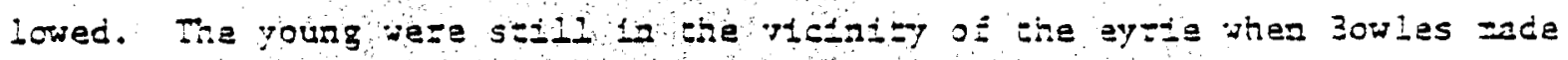
its lase TSLE on T September. 


\section{DISCUSSIOA}

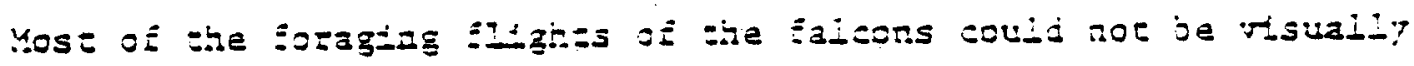
sacked durtag the course of tijs siudy jecausa of lie oogiaches of locil

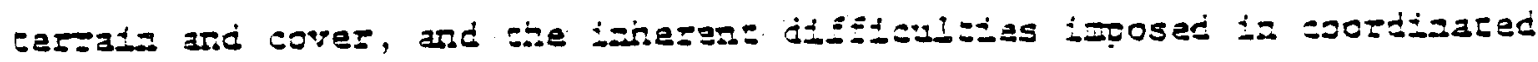

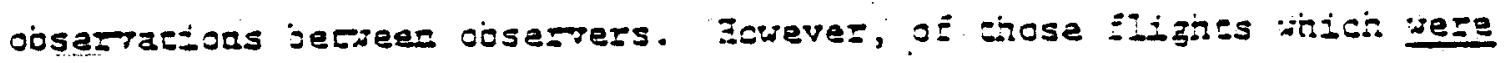
obserred, at least la paz=, some general senderctes emerzed. The Ealsons

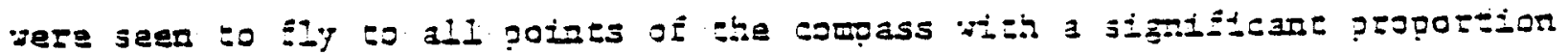

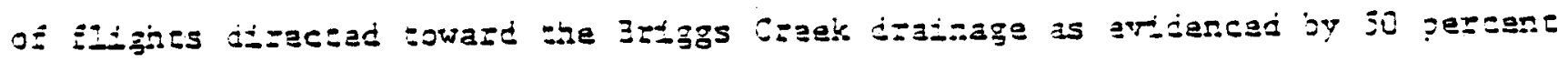

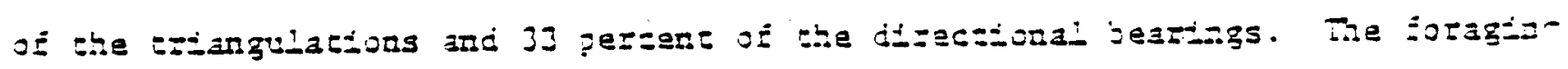

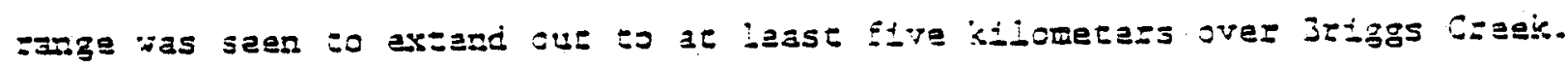

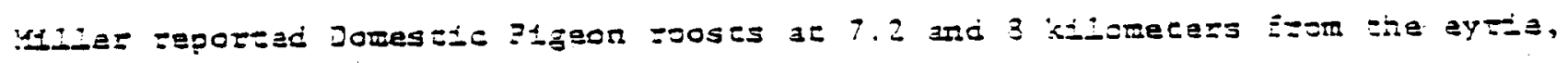

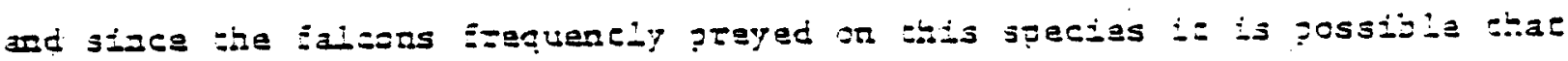

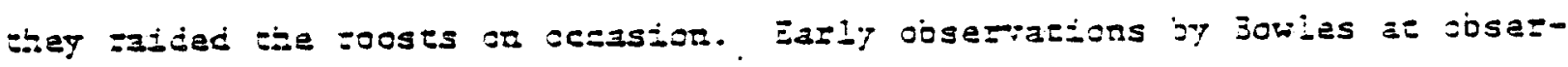

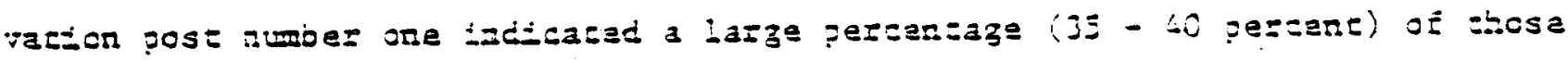

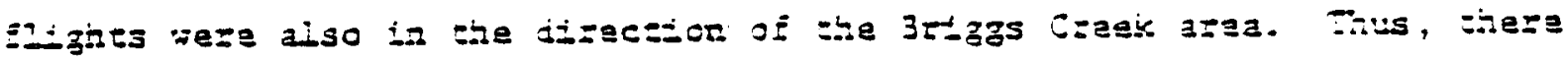

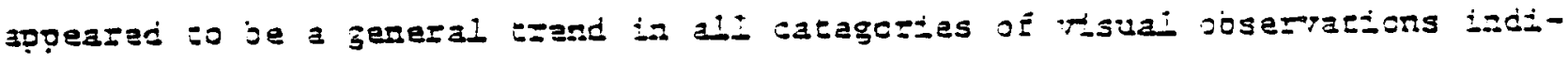

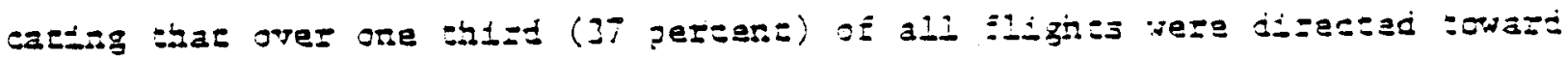

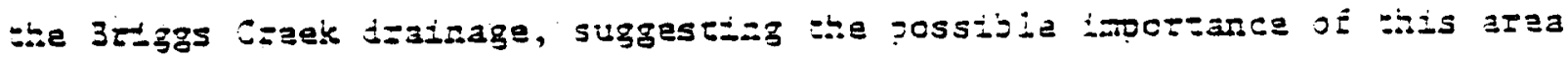
as Soraging babilac.

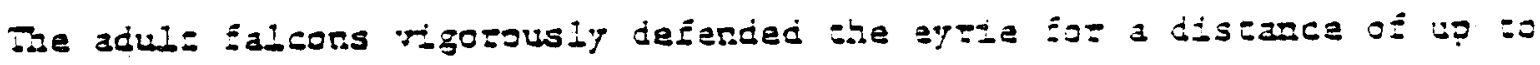

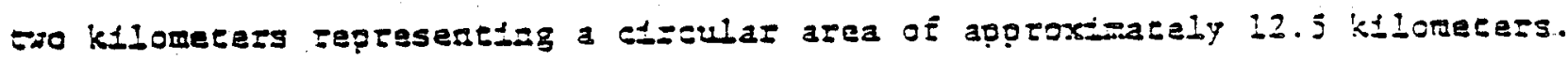

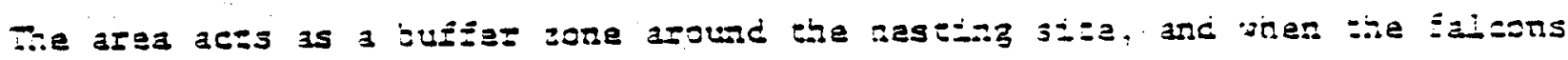

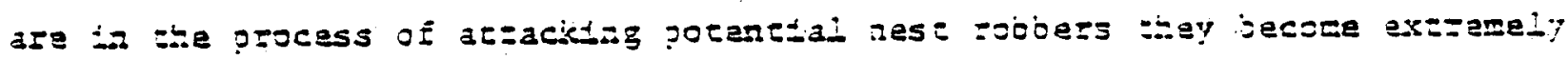

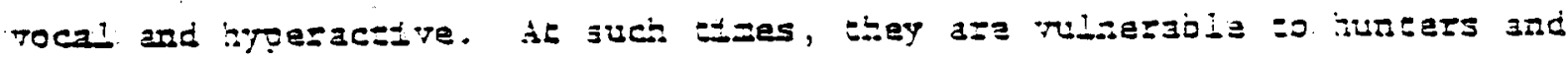

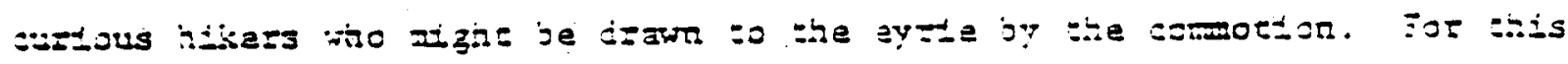

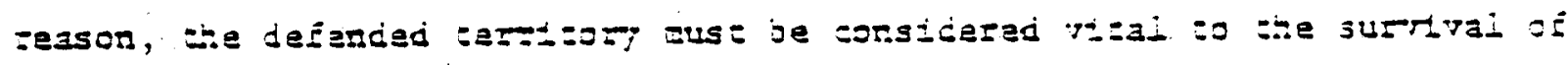


the Peragrires and shouli receive raximum procaction.

Comprehensive daca on prey ilams could not be obcained, bus Erom the early ooserrations at $O P 1$ and the acrual prey gamains coliected at the

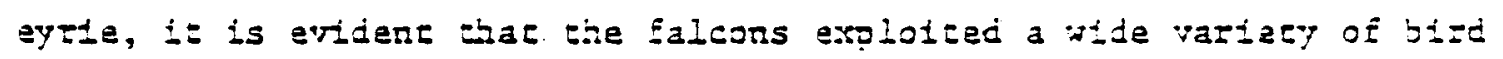
species and at least tio mamals with 22 species gepresanted. Carsalz Columbifor and Passertiorz bfrds zere preyed upon zore frequenty lian others, specistcally pigeons, doves, swallows, starlings, zobiss and jays. 3y comparing the prey lists with the data Egom the lansect bigd population

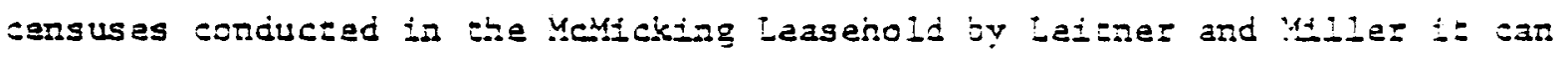
je seen that wize of $4 i$ species ( 19 percent) winich might be considered potental ?eregrine pray (excluding the Great 3 lue Heron, Red-railed "̈awik and Great Jomed owl) obsarved along the combined transects were among the prey Lims of the Ealcons. Hso, seven of 3 I species (23 percent) seen in the

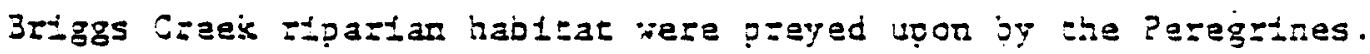

Taking teso consideration that wore than one thi=d of all IItghts

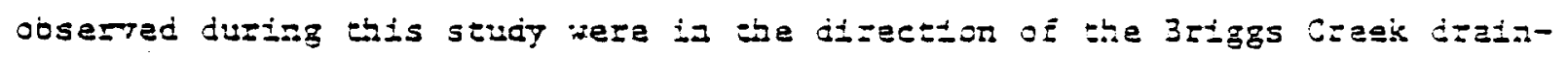
age and that a comparatively higher percentage of lipazian prey species was

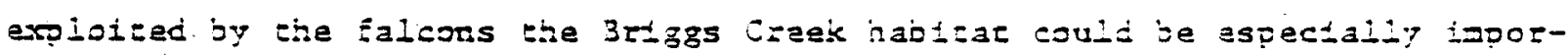
tant as a foraging araa. Racio-teiemerg surcies on the foraging uctirigies

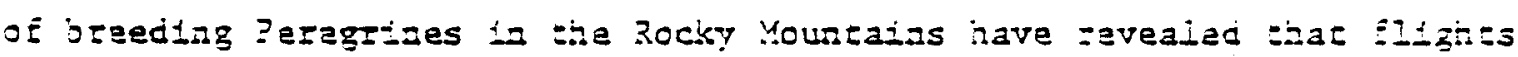
Here dfrected coward selected habilass and not randowiy dispersed (9). In the absence of such data for the falcons constdered in this study in= conclusions about habilal selecticn cannot be dian. Consequencly, is is lise author's opizion that jucgements of the relatige toportance of soragi=g hao-

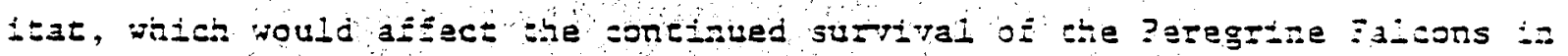

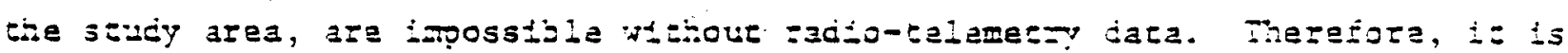
zecomended ihat suci a siudy be urdezakan as sonn as possibia jy expeziencad Ealcon jiologisis. 


\section{SCSTOVLEOCEDE:T}

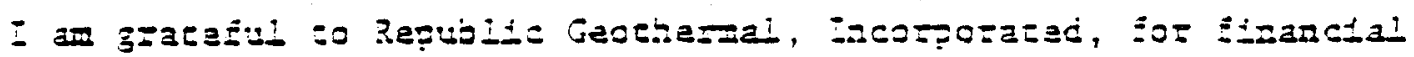

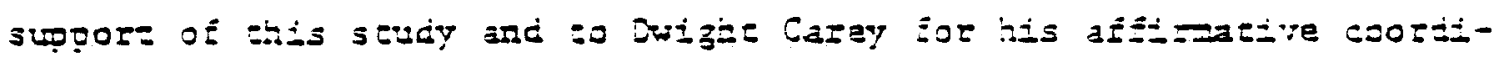

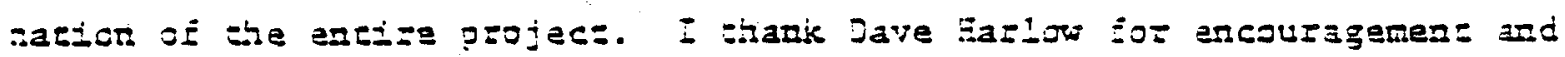
suggestions durtag the taikiai corception stages. A spectal ded of

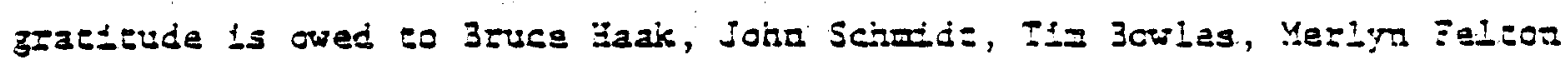
and $3 i 12$ Grumer whose endusance in the jield, enchusiasm, and sintlied

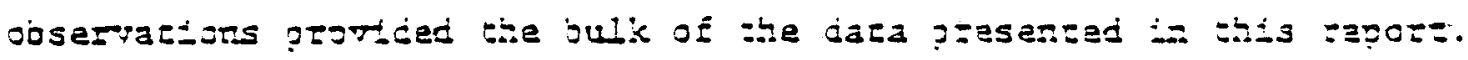

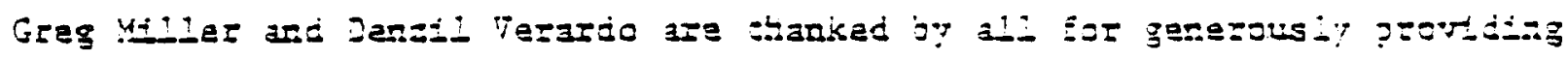

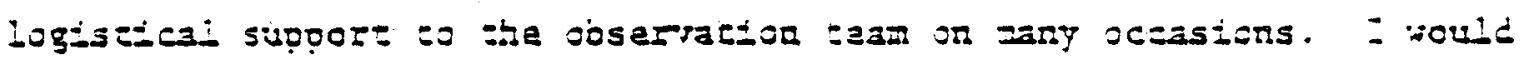

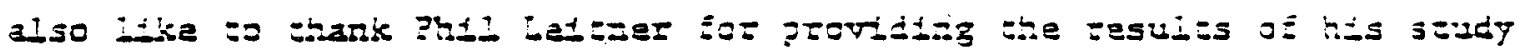

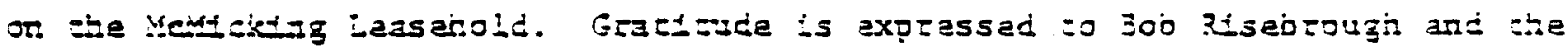

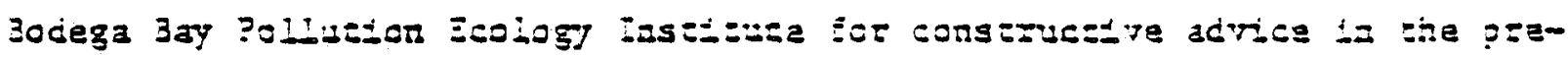
paracion of the intutal proposal. 
i. 1977 Iiss of Endangered and Thzearaned ijildifie.

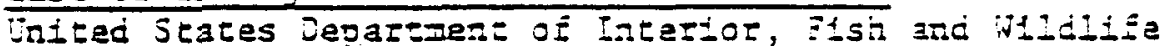
Serfice. Fecieral kegtsies 42 (no. 135): 36425

2. Bickey, $j$. ed 1969. Zeregzize Falcon Pooulations: Jieiz Biology and Decline. The University of iisconsin Piess. Madison, wisconsin.

3. Cade, T., et. al. 1968. Peregrizes and Zesticijeg ia Alaska. Condor $70: 170 .-$

4. Enderson, J., et. al. 1967. Vesting PazForance and Pesticide Residues in tlaskan and Tuken Perggzines. Auk Ej: jó3.-

3. and D. Zerger. 1968. Chicrtnated Eudzocarbon lestiues in

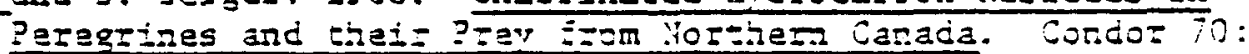
$149 .-$

6. Hickey, I. anc 0 . Arcerson. i360. Glorinated iydrocarjons and Eggsieli Changes in Ractarial and Fisi-äating 3izis. Science 162: 271.-

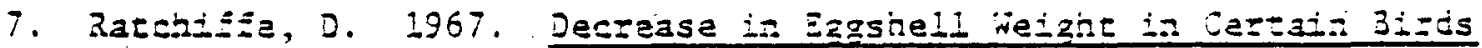
of ?zey. Viature 215: 208 - 210.

3. Riseisrougir, R.i., et. ai. 1967. DDT Residues in Zacizic Sea 31zds: A Zersistant Insecticije in Mariae Food Chains. Jature 216: 589 -

9. Enderson, J. (Personal Comurications)

10. Buminam, 7 .

11. Herman, S., H. Kizren, and R. Riseorough. 1970. The ?ezegzine Jaizon Decline in California. Aucioon Field lotes 24:609-613.

12. Garser=, R. (Personal Comunications)

13. Jarlow, $D$.

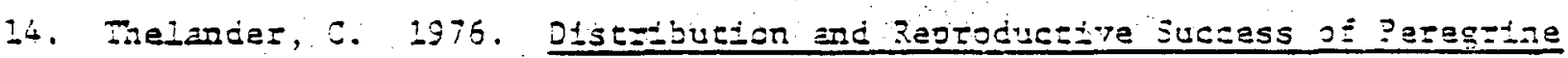
Faisons (Falco pereg-nus anarum) ia Calisoria juring 1975 and

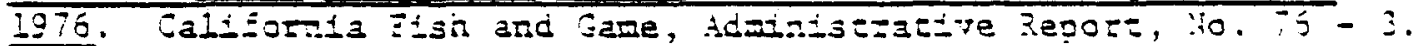




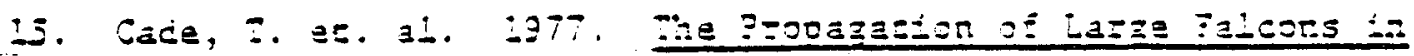

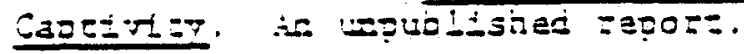

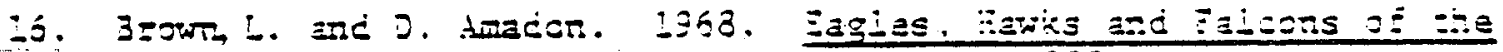

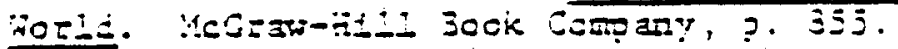




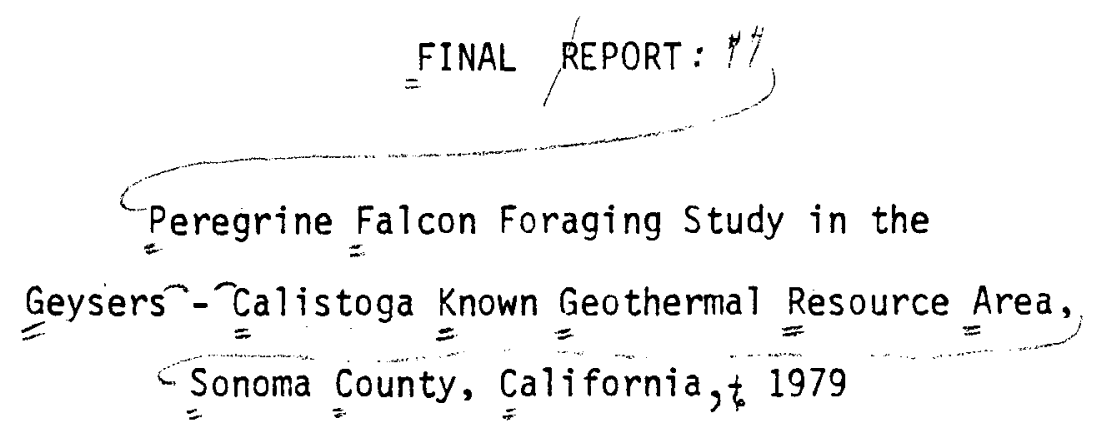

James H. Enderson

and

Monte N. Kirven

Submitted to

Bureau of Land Management

U. S. Department of the Interior

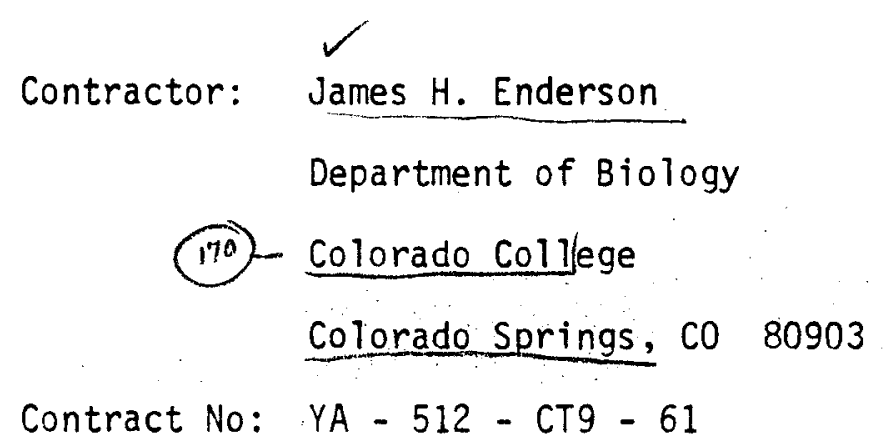


Abstract.

Two adults and two young peregrine falcons were radio-tagged to determine foraging behavior near an eyrie in the Geysers-Calistoga Known Geothermal Resource Area. Equipment failure prevented detailed analysis of movements, but tracking data coupled with data from observers near the eyrie permitted analysis of 139 flights by the female and 40 by the male. Flights were categorized as those less than $1 \mathrm{~km}$ from the eyrie, extending about $1 \mathrm{~km}$ but perhaps proceeding farther, and long flights beyond $1 \mathrm{~km}$. All flights were assigned one of seven vectors, one of which was in the direction of the geothermal area. Long flights on that vector included 9 and $12 \%$ of a 11 long flights for the female and male respectively. Long flights for the female were mainly southeast from the eyrie (36\%) and for the male they were southwest (35\%). The observer data alone in 1979 indicated that $11 \%$ and $15 \%$ of the flights of the female and male, respectively, were toward the geothermal area. Inbound flights by both sexes with prey from the geothermal area included $17 \%$ of all such flights. About $12 \%$ of flights made by both sexes observed in another study in 1978 were to or from the development area, and other 1977 results suggest that up to $33 \%$ were in that direction. The proposed development site is small and lies $6 \mathrm{~km}$ west of the eyrie. The relatively few flights in that direction, the non-selective use by the falcons of flight routes in most other directions, and the general high abundance of prey in the region indicate that development of the geothermal site would not result in significant loss of foraging resource to the peregrines. 


\section{Acknowledgements}

This study vias made possible in large measure by the interest and efforts of T. Cordill of the Sonoma County Planning Office. The field assistants, P. Anderson and B. Braker, often worked under difficult conditions; without their enthusiasm the study would have been far less productive. We have relied on notes taken by other observers including B. Bainbridge, P. Crump, W. Grummer, and R. French, and are grateful for their careful observations and cooperation.

R. Olendorff of the Bureau of Land Management provided administrative direction for the study. The U. S. Fish and Wildiife Service maintained the observers whose field data have been useful. The California Department of Fish and Game approved the study and demonstrated interest in resolving issues relating to impacts on peregrines. 


\section{CONTENTS}

INTRODUCTION

Historical Perspective. . . . . . . . . . . . 1

The 1979 Study. . . . . . . . . . . . . . . 1

METHODS

Equipment.................. 2

Trapping. .................... 3

Operations.................... 3

Interpretation of Telemetry Data. . . . . . . . . 4

Interpretation of Observer Information. . . . . . . 6

RESULTS

Telemetry Information Augmented by Observer Data

General ................... . . 7

Adult female. . . . . . . . . . . . . . . 8

Adult male..................... 9

1979 Observer Data. ............... 10

Analysis of the 1978 Observer Data. . . . . . . . . 11

Analysis of the 1977 Observer Data. . . . . . . . . . 11

DISCUSSION

Flights to the Briggs Creek Drainage and Development Area . 12

Flights to Other Areas. . . . . . . . . . . . 13

Geothermal Powerplant Environmental Considerations. . . . 14

Management Recommendations. . . . . . . . . . . 16

LITERATURE CITED . . . . . . . . . . . . . . . . 17 
TABLE I Characteristics of Long Flights by Adults Determined by Telemetry . 18

TABLE II Distribution of Adult Peregrine Flights by Vector. . . . . . . . . 19

Figure 1 Study Area and Flight Vectors . . . . . . . . . . . . . . 20

Figure 2 Distribution of Flights by the Adult Female . . . . . . . . . . . . 21

Figure 3 Distribution of Flights by the Adult Male . . . . . . . . . . . 22

Figure 4 Distribution of Flights by the Adult Male Seen from Observation

Station .................. 23

Figure 5 Distribution of Flights of Adult Female Seen from Observation

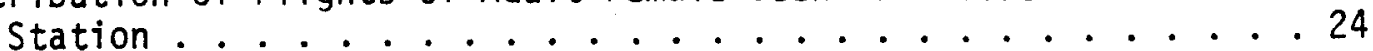

Figure 6 Distribution of Inbound Flights with Prey Seen from Observation

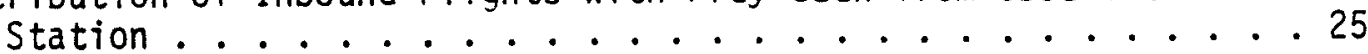

Figure 7 Distribution of Flights of Adults Seen from Observer Stations-1978. 26

Appendix I Field Work Summary. . . . . . . . . . . . . . . . 27

Appendix II Plottings of Telemetry Bearings for Radio-tagged Falcons. . . 35

Appendix III Plottings of Estimated Flight Areas of Radio-tagged Peregrines. 59 
INTRODUCTION

Historical Perspective

The Geysers - Calistoga known Geothermal Resource Area includes the McMicking Leasehold of Republic Geothermal, Inc., a proposed geothermal development site in the Briggs Creek drainage centering $6 \mathrm{~km}$ west of a peregrine falcon (Falco peregrinus anatum) eyrie occupied in the years 1970-73 and 1977 to present. In 1977, M. Kirven and co-workers under contract to Republic Geothermal visually studied the movements of the adults to determine the importance of the development site to foraging peregrines (Kirven 1977). In May, 1978, a research advisory committee, representing the California Fish and Game, the U. S. Fish and Wildlife Service, the Bureau of Land Management, National Audubon Society and the Geothermal Resource Impact Projection Study (GRIPS), was appointed to guide further study. In 1978, visual tracking of the adult falcons was undertaken in a study by M. Kirven for GRIPS. Positions of foraging falcons and headings of hunting flights were obtained, but radio-telemetry studies were indicated because of the limitation of visual range.

The 1979 Study.

The present work sought to reveal the extent of foraging flights, correlate successful hunts with habitat type, and determine the importance of the development area in providing food resource for the peregrines. The movements of adults and young fitted with radio transmitters were to have been monitored throughout flights away from the eyrie by triangulation of bearing data simultaneously obtained by two tracking receivers. Equipment malfunction and breakage prevented completion of 
these goals. Useful telemetry data on foraging regions were obtained for the adult falcons and permit an analysis of the relative importance of the Briggs Creek drainage to the birds. This report also includes an analysis of the visual data obtained in 1977 and 1978 in light of the present study and integrates 1979 observations by U.S. Fish and Wildlife Service observers stationed near the eyrie.

\section{METHODS}

\section{Equipment}

Telemetry receivers were AVM Instrument $\mathrm{RB}-4$ single-channel instruments with three sub-channels. SM-1 transmitters weighing $15 \mathrm{~g}$ were matched to the receivers in the $148.075-148.125 \mathrm{MHz}$ range permitting distinction among six transmitters. Transmitters were fitted with batteries providing power for up to 90 days depending on requirements of each transmitter. Transmitters, coated with dental acrylic, were fitted with $38 \mathrm{~cm}$ guitar wire antennas 0.011 inches in diameter.

Tracking station antennas were four-element directional yagis mounted on three-meter rotating masts equipped with bearing discs at the bases. Co-axial cable $4 \mathrm{~m}$ long linked antenna to receiver. Head phones reduced outside noise. $C B$ transceivers powered by automotive batteries or mercury cells provided communications between tracking stations and the observer near the eyrie. Tracking stations were established on the summit of Mount Saint Helena (MSH) $2 \mathrm{~km}$ south of the eyrie, and on Chalk Point (CP) $4 \mathrm{~km}$ southwest because they maximized line-of-sight coverage of the region (Fig. 1).

Two separate tests established bearing error on a test transmitter 
$8 \mathrm{~km}$ from receiver. The error was $\pm 5^{\circ}$, but one $8^{\circ}$ error was obtained. Maximum line-of-sight range exceeded $15 \mathrm{~km}$, but intervening terrain interrupted transmission. Bearings of instrumented birds were taken at 30-second intervals when possible.

Trapping

Adults and young were trapped in the vicinity of the eyrie with nets or snares; they were then hooded, instrumented, and released immediately. The male was to be trapped in April, the female in late May, but the female was caught on 21 April and fitted with a transmitter sewn to a single tail feather. The male was elusive and not caught or instrumented in the manner of the female until 2 June. Both birds behaved normally upon release. The young were not radio-tagged in the eyrie because of high risk of flushing them from the ledge prematurely. Four young began fledging on 11 June, but only three males were present when trapping began on 24 June. One was caught on 24 June; another was trapped on 25 June. Both were fitted with tail-mounted transmitters. The third young could not be caught because his perching and feeding areas became unpredictable.

\section{Operations}

Appendix I provides a summary of field operations from 17 March - 6 July. Prior to 21 April the nesting situation was checked, and equipment was readied. The female's transmitter operated from 21 April to 1 June when the antenna separated. In that period, useful telemetry data (usually wi thout triangulation) was obtained on 14 days. Poor weather and transceiver malfunction 
were major and recurring problems. Trapping operations sometimes pre-empted tracking.

The adult male provided only four days of tracking data, some of it involving triangulation, in the period 3-6 June. On the latter date the antenna separated from the transmitter.

The young male instrumented on 24 June provided tracking data on only one day; that transmitter lost useful strength by 3 July. The second young male was equipped with a transmitter on 25 June, but the pulse rate slowed almost immediately, became erratic, and failed within the day.

\section{Interpretation of Telemetry Data}

Telemetry information for the female consisted mainly of headings taken on MSH on 14 days in the period 21 Apri1 - 31 May. The female was incubating. or brooding small young in that period and on only one day were simultaneous headings obtained at MSH and CP. The adult male ranged more widely, and triangulation data were obtained in three of the four days his transmitter operated. One young was tracked from MSH on 1 July, nearly three weeks after fledging.

The field data, consisting of bearings and corresponding times, notations by tracking station operators, and notes taken by the FWS observer near the eyrie were collated in the following way:

1) Bearings were drawn from the tracking station on an overlay of a USGS 7.5 min topographical map. The time the bearing was obtained was noted along the line (Appendix II).

2) Remarks written by the station operators or received from the eyrie observer by transceiver were written on the bearing overlays where they related to movement of the falcon. 
3) The notes of the FWS observer were summarized in regard to falcon movements to and from the eyrie for the days when telemetry data were available.

4) The general route of flights made in one day were traced on overlays of the topographic map integrating telemetry bearings, triangulation data when available, notes taken by trackers, and the observers' notes (Appendix III). The resulting routes do not indicate the exact route of each flight, but only its general course based on signal direction, strength, flight courses seen by the FWS observer, and time intervals between sequential bearings. For example, a great shift in bearings 30 seconds apart coupled with a strong signal imply the bird was passing near the station. Sudden loss of signal implied the bird passed behind intervening terrain. Some segments of flights were uncertain; these were indicated by dashed lines.

5) Overlays of the generalized flight routes were then analyzed, fight by flight, in terms of the general regions through which the flight passed. These routes or vectors, are shown in Fig. 1 and are flight corridors normally used by the adults. Several vectors correspond to topographical features:

F1 - westward from eyrie over ridge into Briggs Creek drainage and the region of proposed geothermal development;

F2 - southwest on ridge toward the tracking station at Chalk Point and upper Knight's Valley;

F3 - southwest down canyon to lower Knight's Valley;

F4 - south from the eyrie toward the tracking station on Mount Saint Helena and southward;

F5 - southeast from eyrie on the east side of County Line Ridge 
F6 - east from the eyrie toward St. Helena Creek drainage; and

F7 - northeast from the eyrie, past Tom Dye Rock toward Collayomi Valley.

When a flight, or part of a flight on the general route overlays involved a vector, a mark was placed on the vector (Fig. 2). Marks on each vector in Fig. 2 and 3 represent three categories of flights:

1) Marks on vectors plotted near the eyrie, within the $1.0 \mathrm{~km}$ radius circle, represent flights in the corridor during which the falcon did not fly farther than $1.0 \mathrm{~km}$ from the eyrie.

2) Marks on vectors plotted at the $1.0 \mathrm{~km}$ circle represent flights that may or may not have exceeded about $1 \mathrm{~km}$ from the eyrie.

3) Marks near the far ends of the vectors represent flights known to have exceeded $1 \mathrm{~km}$ from the eyrie in the region of the vector, but the precise extent of the flight was not often determined.

Interpretation of Observer Information

1979. A FWS observer was stationed at a vantage point $350 \mathrm{~m}$ south of the eyrie on 52 days in the period 3 April - 19 June. This observer recorded the arrival, departure, and other behaviors of the falcons. This information was used with telemetry data to reconstruct generalized flight routes of the falcons. The observer data were also examined for patterns in the use of flight vectors and for vectors used during arrivals from successful hunts.

1978. From 30 May to 20 August two observers (one $350 \mathrm{~m}$ south, the other $760 \mathrm{~m}$ southwest of the eyrie) cooperated by radio to determine the flight bearing of adults when finally lost from view (Kirven 1978). The 
report provides a map of 65 positions and the direction of flight for each. These data were plotted on the same vector system applied to the 1979 results.

1977. From 9 July to 7 September 1977 observers were stationed at vantage points in the vicinity of the eyrie to determine the direction of flights of the foraging adults (Kirven 1977). Whenever possible, positions of the birds were determined simultaneously by two observers and triangulated. These positions and the data on flight direction are analyzed in this report in terms of the seven flight vectors.

\section{RESULTS}

Telemetry Information Augmented by Observer Data

General. Figures 2 and 3 show the distribution of flights, or Dortions of $\mathrm{flights,} \mathrm{from} \mathrm{the} \mathrm{overlays} \mathrm{of} \mathrm{generalized} \mathrm{routes.} \mathrm{Marks} \mathrm{with-}$ in the $1 \mathrm{~km}$ radius represent round-trip flights and were often substantiated by notes made by the FWS observer stationed $300 \mathrm{~m}$ south of the eyrie. These flights, sometimes interrupted by perching, usually of short duration, included a few hunting flights and defense flights.

Marks plotted on the $1 \mathrm{~km}$ circle were known to approach $1 \mathrm{~km}$ from the eyrie, but may have gone farther because the beacon signal was lost or the falcon was lost from view. These flights, including round-trips and isolated departures and arrivals to the eyrie, are useful in that they suggest the regions where the falcons hunted.

Marks near the ends of the vectors represent round-trip flights, or portions of flights, judged to be in the area represented by the vector. When a flight passed more than one vector, a mark was placed on each vector involved; a single flight is represented by a mark on different vectors in 
these cases. When a falcon returned to a vector left earlier in the same flight a second mark was entered. Marks for flights beyond $1 \mathrm{~km}$ do not reveal the precise distance from the eyrie or the time spent in the area of the vector.

Adult female. The beacon of the adult female provided useful information on her position for 14 days in the period 27 April - 31 May 1979 (Fig. 2). Flights less than $1 \mathrm{~km}$ from the eyrie centered on vectors $F 1$ and $F 7$, both including favored perches and loafing areas. Vector $F 5$ passes an apparent perching area southeast of the eyrie, but often the female's position there was uncertain because a ridge blocked radio reception from Mount Saint Helena.

Long flights, over $1 \mathrm{~km}$ from the eyrie are of most interest, especially when they were toward the proposed development site on vector $F 1$. of 64 such flights recorded on Fig. $2,6(9 \%)$ were known to have crossed the ridge westward toward Briggs Creek and the development area. Some long flights on F2 may have turned northward to FI; long flights of both these vectors include $25 \%$ of all. long flights. Long flights with southerly components on vectors F2, F3, F4, and F5 include about $90 \%$ of all long flights. Over one-third of all long flights were on vector $F 5$ to the southeast.

Some flights of unknown distance probably exceeded $1 \mathrm{~km}$ from the eyrie. If these 41 flights are added to the 64 long flights, 105 flights result; 13 are on vector $F 1$ and are about $12 \%$ of all such flights. Long flights and those of unknown distance on vector $\mathrm{F} 5$ amount to $35 \%$ of all these flights. The telemetry and observer data in Fig. 2 indicate the adult female flew mainly toward the south when she left the area within $1 \mathrm{~km}$ of the eyrie, and used the area of the proposed development uncommonly 
in the period of observation.

Adult male. The beacon of the adult male provide useful information in the period 3-6 June 1979 (Fig. 3). Long flights on F1 included 12\% of all long flights. Flights known not to have exceeded $1 \mathrm{~km}$ from the eyrie include two westward along the ridge on $\mathrm{Fl}$ and one to a perching area northeast of the eyrie on $F 7$, together comprising $8 \%$ of all flights. Flights that may have exceeded $1 \mathrm{~km}$ are mainly on F1 (four flights) and on F7 (five flights). These amount to $23 \%$ of all flights. Flights exceeding $1 \mathrm{~km}$ included all vectors, but 9 of $26(35 \%)$ were on F2 southwest of the eyrie.

Some of the 11 flights of unknown distance probably exceeded $1 \mathrm{~km}$ from the eyrie. These added to 26 long flights total 37 flights; 7 (19\%) are on vector F1 in the direction of the proposed development, and $9(24 \%)$ of such flights were on the adjacent vector F2. The telemetry data supplemented by observer information in Fig. 3 indicate the male distributed his flights, in this brief period, more or less uniformly on most vectors, but known long flights predominate on F2 southwest of the eyrie.

Nineteen long flights by the adults were tracked beyond about $3 \mathrm{~km}$ from the eyrie (Table I). The locations of four of these flights were substantiated by telemetry triangulation; the others are inferred by signal strength and direction from CP or MSH tracking stations. Most of these flights were southwest, and some exceeded $7 \mathrm{~km}$ from the eyrie.

Flights by young. Only on 1 July was the young falcon with a functioning transmitter tracked out of the eyrie area. That male made three excursions to MSH: 1) down the ridge SW of the eyrie, south across the canyon to MSH, east to County Line Ridge and NW to the eyrie; 2) south from eyrie to the summit of MSH, probably south around the summit to the north side, circled NE of the summit, passed in view tracking station headed NW; 
3) approached MSH from the NW, south and east around the summit, passed the tracking station and probably dropped northward under the summit toward the eyrie.

1979 Observer Data.

A variety of conditions precluded observation of all flights to and from the eyrie by the FWS observer, but 222 were recorded for the male (Fig. 4) and 215 for the female (Fig. 5) in the period 3 April - 19 June. The male showed surprisingly uniform use of all vectors within the visual range of the observer, except that flights on vector F7 to a perching hunting area to the northeast predominated. Flights on F1 in the direction of the proposed geothermal development account for $15 \%$ of all flights. Some flights on F2 may have been in that area; F1 and F2 flights collectively include $31 \%$ of all flights seen by the observer. The female (Fig. 5) also showed uniform distribution of flights by vector, except she favored $F 5$ to a perching area. Only $11 \%$ of her flights were on $\mathrm{Fl}$ and $23 \%$ were on $\mathrm{F} 1$ and F2.

In 92 instances the observer recorded inbound flights by adults with prey (Fig. 6). These flights suggest the regions of hunting success because adults carrying prey probably return directly to the eyrie from the site of the kill. The male was seen inbound 72 times, especially from the northeast and south to west. The female brought in prey mainiy from the south to west. Sexes combined, $17 \%$ of inbound flights with prey were on $\mathrm{Fl}$, and $40 \%$ on FI and $F 2$. 
Analysis of the 1978 Observer Data.

The report (Kirven 1978) includes a map of 65 positions and direction of flight when the adults were lost from view. These data can be plotted on the vectors used in 1979 (Fig. 7). Sometimes positions were midway between vectors and in these cases a vector was assigned if the direction of flight was toward the vector. Most importantly, falcons flying on the ridge southwest of the eyrie were assigned vector $F 1$ if their flight direction was toward the development area. The plots in Figure 6 do not distinguish flight distance from the eyrie since many were lost from view while in progress. About $12 \%$ of the flights are on $\mathrm{Fl}$ and $37 \%$ are on $\mathrm{FI}$ and F2 combined. In 1978 the great majority of the flights had a southerly component.

Analysis of the 1977 Observer Data.

Positions of flying adults were determined simultaneously by two observers and triangulated. Directional bearings were recorded for the birds when lost from view. Terrain limited visibility such that 13 of 20 triangulations were within $1 \mathrm{~km}$ of the eyrie, 5 were within $2.2 \mathrm{~km}$, and 2 were $4-5 \mathrm{~km}$ from the eyrie. Four of the triangulations beyond $1 \mathrm{~km}$ were in the direction of the proposed development. About $55 \%$ of all triangulations were in the general direction of the development (Kirven 1977).

In 1977, 71 directional bearings were recorded for the adults as they were lost from view. Of these 24 , or $33 \%$, were in the general direction of the development area. 


\section{DISCUSSION}

Flights to the Briggs Creek Drainage and Development Area.

Flights on vector $F 1$, some of those on F2, and perhaps a few involving other vectors may proceed into the Briggs Creek drainage (Fig. 1). The area of the proposed development site is small relative to the drainage; flights to the drainage do not necessarily include the development area.

Not all flights on $F 1$ and $F 2$ extended beyond $1 \mathrm{~km}$ from the eyrie in 1979. Of 55 flights determined by telemetry and augmented by observer data, 14 or $25 \%$, did not exceed $1 \mathrm{~km}$.

Table II summarizes the distribution of flights by vector determined by different means 1977-79. Flights on F1 in 1978 and 1979 include less than $20 \%$ of all flights. When flights on F1 and F2 are combined, up to $40 \%$ of all flights are included, a result not unexpected because $F 2$ is along a ridge providing access to regions west and south. The 1977 data for F1 and F2 include those listed as "towards Briggs Creek" or "from Briggs Creek" (Kirven 1977). About half of the 1977 flights were in this group, a result probably biased upwards by the position of one observer $760 \mathrm{~m}$ from the eyrie on F1. Flights on other vectors were less well observed.

The Bureau of Land Management administers about $10.4 \mathrm{~km}^{2}$ of land extending from about $3 \mathrm{~km}$ northwest of the eyrie to about $6 \mathrm{~km}$ north of the eyrie (Fig. 1). More extensive BLM lands lie northwest of this tract. BLM land would be encountered along about one-third of all bearings between north and west of the eyrie. Flights on F1 and possibly a few on F2 are within that sector. On that basis, a very rough prediction of use of BLM land by peregrines can be made. If less than $20 \%$ of all flights are on FI (Table II) and $25 \%$ of these are less than $1 \mathrm{~km}$ from the eyrie, only $15 \%$ of all flights could reach BLM land. If these flights extended to $3 \mathrm{~km}$, only about $5 \%$ would reach BLM land if no 
preference for direction of flight within the northwest sector were shown.

Flights to Other Areas.

The pattern of flights by the adults at this eyrie in the breeding season is spread more or less eveningly among those available. Some vectors, taken together include obvious corridors to hunting areas. Vectors F2, F3, and F4 comprise the northwest slope of Mount Saint Helena, Rattlesnake Canyon, and Knight's Valley to the southwest. Betireen one-third and onehalf of all flights were on these vectors, depending on the year and type of study (Table II.) Similarily flights on F5, F6, and F7 to the east include the vast Collayomi Valley and the east slope of Mount Saint Helena. Between about one-third and one-half of all flights were on these vectors.

The uniformity of distribution of flights, many of which are foraging flights, may be due to the obvious abundance of prey in the region. Bird count transects were made in 1977 by G. Miller and P. Leitner in the McMicking Leasehold (Kirven 1977). They found 324, 550, and 521 birds per mile of transect in two mixed forests and a riparian habitat, respectively. For comparison, averages of 84,148 , and 160 birds were seen per mile of transect in mixed forest, meadow, and riparian habitat, respectively, in colorado. These represent the richest of 13 habitats sampled near six Rocky Mountain peregrine eyries (Enderson 1977).

Two other studies of radio-tagged breeding adult falcons allow comparisons of the patterns of flight distribution. A female peregrine tracked by triangulation from 7 June - 19 July 1977 distributed her foraging flights in many directions from the eyrie in Colorado (Enderson 1977). That peregrine appeared to favor mixed forest-brushland-meadow habitat and seemed to avoid pure stands of forest, sometimes ranging up to $19 \mathrm{~km}$ from the eyrie. Prairie falcons (Falco mexicanus) in Idaho, on the other hand, focused their foraging 
flights in limited sectors of the potentially available habitat (Dunstan 1978). Perhaps this use limited to sectors resulted from competition with other adjacent pairs in that region of high prairie falcon density, and from the asymetrical distribution of particularily good foraging habitat. In Colorado, as in the present study, suitable habjtat was available in many directions.

It may be reasonable to generalize the results of the present study, and the other radio-tracking studies, to the foraging behavior of nesting peregrines elsewhere in the interior of California. The Mount St. Helena eyrie is located near the top of a divide between distant valleys. There are essentially no high barriers of terrain in almost every direction from the eyrie. In the 1977 Colorado study, the eyrie was on the highest point within $3 \mathrm{~km}$. Both situations allowed foraging adults easy access in every direction. In both situations suitable prey was probably spread throughout the region around the eyrie. Under these conditions peregrines could be expected to distribute foraging flights in all directions. Conversely, where terrain much higher than the eyrie forms a nearby barrier or where prey abundance is strongly irregular as in the Idaho prairie falcon study, peregrines could be expected to show pronounced preference in the use of habitat for hunting.

Geothermal Powerplant Environmental Considerations.

The construction and operation of a geothermal powerplant on the McMicking Leasehold would increase noise, water vapor, hydrogen sulfide levels, and obstructions in the Briggs Creek drainage. Construction equipment can produce up to $95 \mathrm{dBA}$ within 50 feet. Plant operation a full load can produce up to $93 \mathrm{dBA}$ at the steam ejectors, but these high frequency sounds attenuate rapidly with distance. Given the intervening terrain between the 
eyrie area and the development site, separated by a distance of $6 \mathrm{~km}$, sound reaching the eyrie would almost certainly be nominal. Peregrines adjust to high noise levels. A nest ledge used for many years in the eastern United States was blackened by nearby steam locomotives, and two eyries active in the 1970's in the Rocky Mountains are within i $\mathrm{km}$ of coal-fired electric plants.

Increased water vapor content of the atmosphere increases fog likelihood within $2 \mathrm{~km}$ of geothermal plants. Fog may hamper peregrine foraging. Predictions of this effect are difficult, but since conditions favoring fog are projected at less than five percent on an annual basis, increase of fog in a significant area of the falcon foraging range seems unlikely.

The possible effects of increased hydrogen sulfide on the avifauna of the Briggs Creek drainage are unknown. Emission by new geothermal power plants are expected to conform to the California ambient air quality standard of 30 parts per billion. The eyrie is 2600 feet higher than the geothermal site, a differential reducing the possible effects of much higher concentrations during temperature inversions.

Power transmission lines are a hazard to peregrines because their attack dives may exceed $150 \mathrm{mph}$. Collisions with wires are well-known; at least six occurred in California in recent years (Kirven pers. comm.) and in 1978 in Colorado a young peregrine struck a power line $2 \mathrm{~km}$ from its eyrie and suffered a broken wing.

It is a mistake to assume peregrines are necessarily sensitive to or intolerant of all types of human activity within the eyrie foraging area. In Colorado, Enderson has studied 13 eyries used by peregrines in the 1970's. Nine were active at least one year in the period 1977-79 and of these 5 had highway traffic below the eyrie within $1 \mathrm{~km}, 2$ had light traffic or pedestrians to within $0.5 \mathrm{~km}$, and 2 were remote from disturbance. Of the four eyries not 
active 1977-79, 1 was remote and 3 were often visited by pedestrians or rock-climbers; the latter are probably serious threats to nesting peregrines where the disturbance is continuous.

Management Recommendations

The following recommendations are based on the results of this study and on projections of impacts attending development on the McMicking Leasehold. The present study strongly implies that no significant loss of foraging habitat would result from geothermal power development confined to the leasehold, assuming that present prey abundances and the distribution of flights by the peregrines does not change importantly in the future.

1. The effect of development on prey and falcon use of the Briggs Creek drainage cannot presently be predicted. Careful records should be obtained each year (perhaps by a FWS observer) on flight distribution and the duration of foraging flights, to reveal changes in use of the drainage and apparent ease of obtaining food. Such data can be compared with the results of this and earlier studies.

2. Construction and operational activities associated with power development must not increase human presence within the area designated as Critical Habitat. Traffic on Ida Clayton Road is certain to increase during the construction phase. Access routes to the eyrie from that road should remain closed. 
3. Power transmission lines should be routed only down the Briggs Creek drainage westward from the development site; none should be built in Rattlesnake Canyon or adjacent Knight's Valley. Future plans to build transmission lines within about $12 \mathrm{~km}$ of the eyrie should be reveiwed on the basis of the flight distribution found in the present study.

4. The Fish and Wildlife Service should continue its observer program at this eyrie, extending the observation period to 1 March - 1 August. A major objective should be to discourage pedestrian and off-road vehicle access to the eyrie.

5. Affected agencies should secure land-owner cooperation or obtain ownership of properties within the designated Critical Habitat to assure no increase in habitat loss or disturbance.

6. The State of California and other affected agencies should develope a Nest Territory Plan for the eyrie as has been done for most Bald Eagle territories in California.

\section{LITERATURE CITED}

Dunstan, T. C. 1978. Habitat use and hunting strategies of prairie falcons, red-tailed hawks, and golden eagles. Bureau of Land Management Contract Report (unpublished).

Enderson, J. H. 1977. Habitat analysis and eyrie survey of the peregrine in Colorado - 1977. Colorado Division of Wildlife Report (unpublished).

Kirven, M. N. 1978. Peregrine falcons of Mount Saint Helena in the Geyers-Calistoga Known Geothermal Resource Area. Geothermal Resource Impact Project Study Report (unpublished).

Kirven, M. N. 1977. A preliminary study of the peregrine falcons in the proposed geothermal development area, Sonoma County, California. Republic Geothermal, Inc., Santa Fe Springs, California (unpublished). 


\section{TABLE I}

Characteristics of Long Flights by Adults

Determined by Telemetry

Date Approximate Distance from eyrie

Area of flight

Triangulation evidence

Female:

$\begin{array}{lll}1 \text { May } & >3 \mathrm{~km} & \text { SW of MSH } \\ 2 \text { May } & >3 \mathrm{~km} & \text { SE of MSH } \\ 16 \text { May } & 2.5 \mathrm{~km} & \text { W of MSH } \\ 18 \text { May } & 3 \mathrm{~km} & \text { SW of MSH } \\ 23 \text { May } & 7 \mathrm{~km} & \text { Knight's Valley } \\ & 7 \mathrm{~km} & \text { Knight's Valley } \\ & >3 \mathrm{~km} & \text { Brigg's Creek } \\ & 3 \mathrm{~km} & \text { Brigg's Creek } \\ 26 \text { May } & 3 \mathrm{~km} & \text { SW of MSH } \\ & 4 \mathrm{~km} & \text { SE of MSH } \\ 28 \text { May } & 3 \mathrm{~km} & \text { SW of MSH } \\ 31 \text { May } & 4 \mathrm{~km} & \text { W of Fish Hatchery }\end{array}$

Male:

\begin{tabular}{|c|c|c|}
\hline 3 June & $>6 \mathrm{~km}$ & $W$ of $C P^{2}$ \\
\hline \multirow[t]{2}{*}{4 June } & $>7 \mathrm{~km}$ & $W$ of $C P$ \\
\hline & $5 \mathrm{~km}$ & S-SE of MSH \\
\hline \multirow[t]{3}{*}{5 June } & $>7 \mathrm{~km}$ & $\mathrm{CP}$ area \\
\hline & $>4 \mathrm{~km}$ & Knight's Valley \\
\hline & $6 \mathrm{~km}$ & Knight's Valley \\
\hline 6 June & $>3 \mathrm{~km}$ & lower Rattlesnake \\
\hline
\end{tabular}




\section{TABLE II}

Distribution of Adult Peregrine Flights by Vector

Type of Data

1979:

Telemetry and observers ${ }^{1}(n=179)$

Observers $^{2}(n=437)$

Observers - Flights with prey ${ }^{3}(n=92)$

1978:

Observers $^{4}(n=65)$

1977:

Observers - Visual triangulation $5(n=20)$

observers - Directional bearings ${ }^{6}(n=74)$
Vector (\% of all flights)

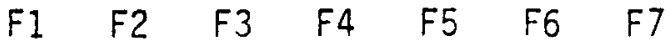

$\begin{array}{lllllll}19 & 12 & 11 & 11 & 26 & 5 & \text { i6 }\end{array}$

$\begin{array}{lllllll}13 & 14 & 16 & 12 & 16 & 10 & 19\end{array}$

$\begin{array}{lllllll}17 & 23 & 14 & 16 & 9 & 3 & 18\end{array}$

$\begin{array}{lllllll}12 & 25 & 14 & 15 & 19 & 9 & 6\end{array}$

1 calculated from Fig. 2 and 3

2 calculated from Fig. 4 and 5

3 calculated from Fig. 6

4 calculated from Fig. 7

5 from Kirven (1977)

6 from Table I, Kirven (1977)

7 includes flights "toward or from Briggs Creek" 


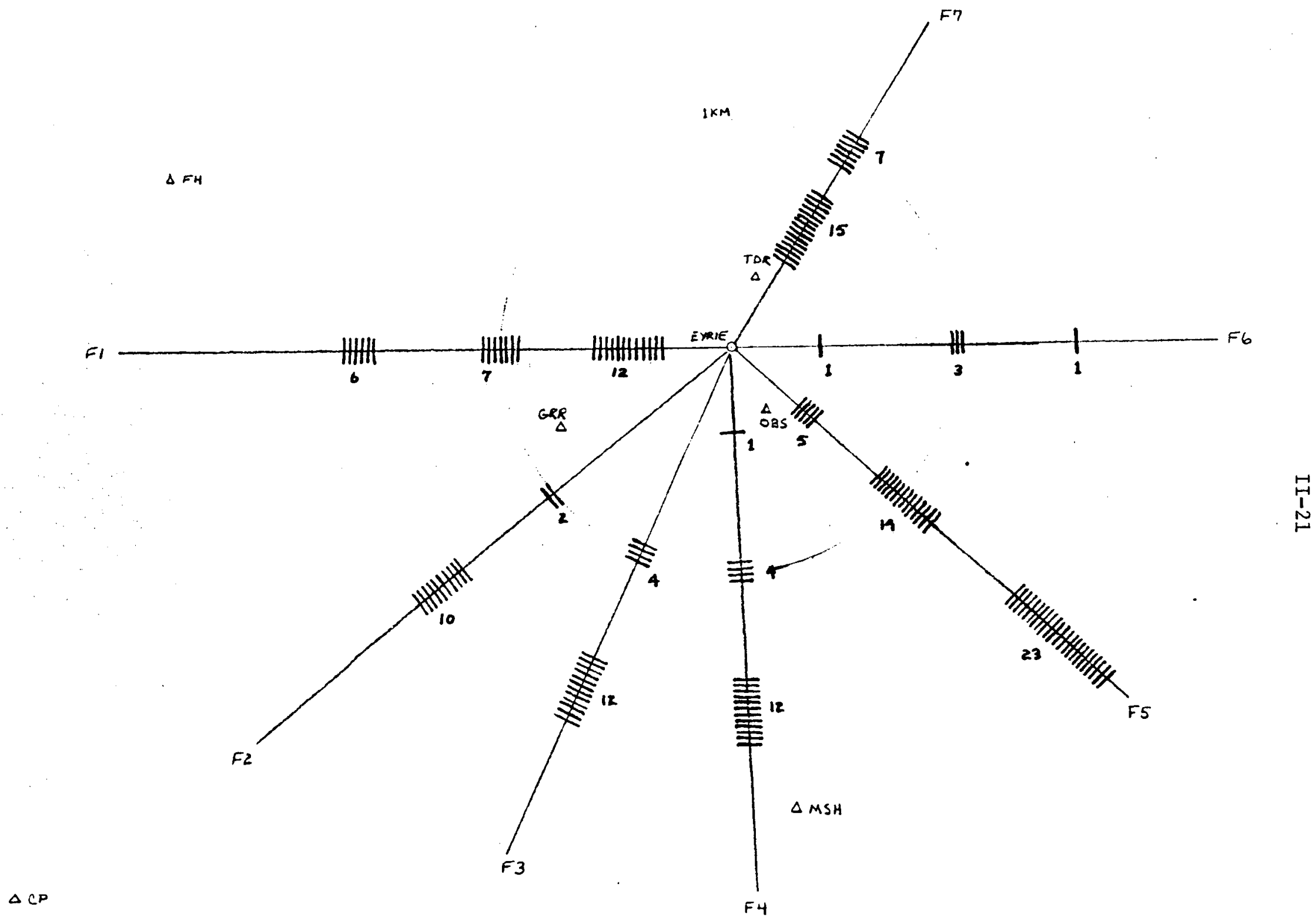

FIGURE 2 Distribution of Flights by the Adult Female

27 April - 31 May 1979 


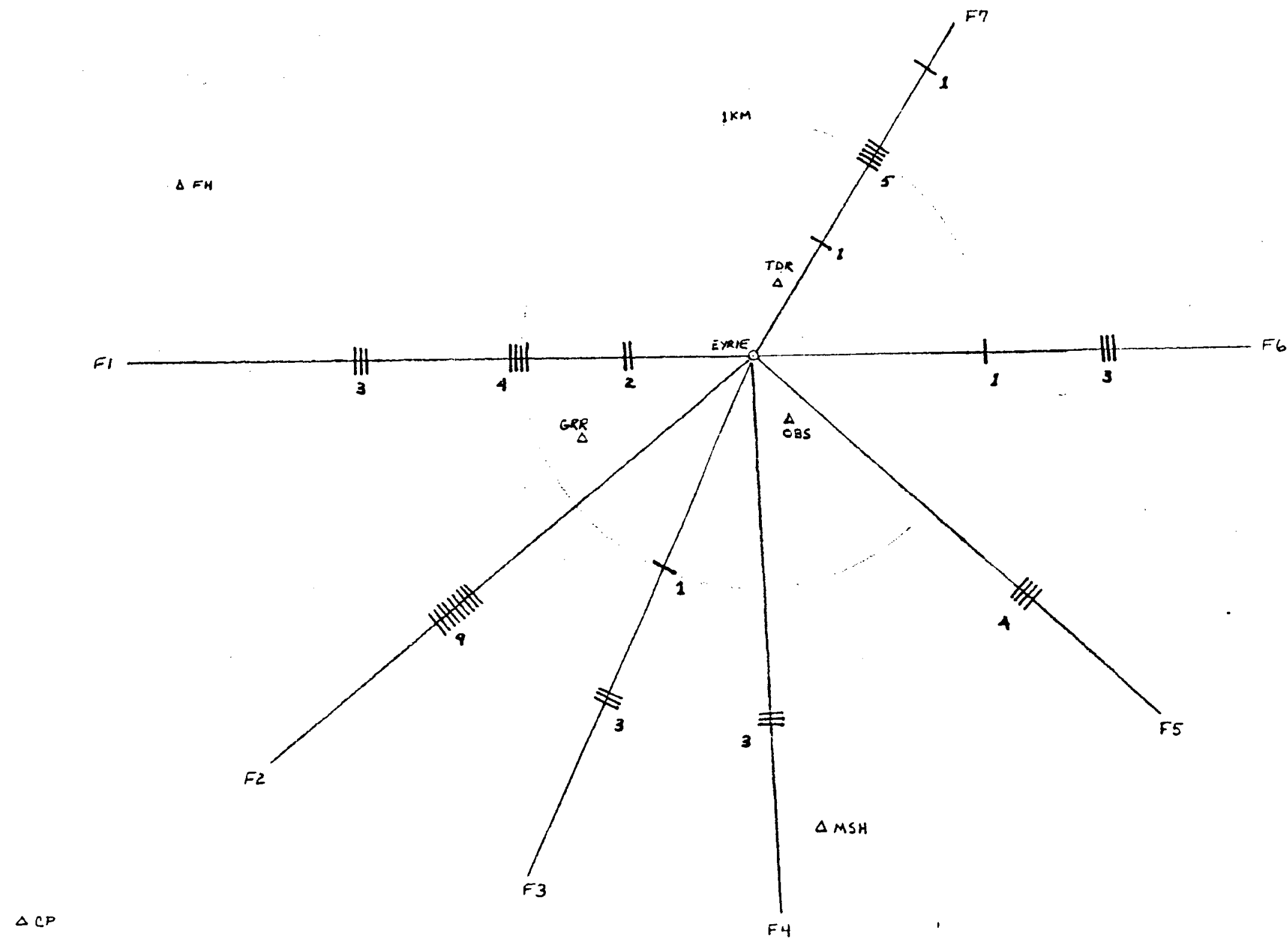

FIGURE 3 Distribution of Flights by the Adult Male 3 - 6 June 1979 


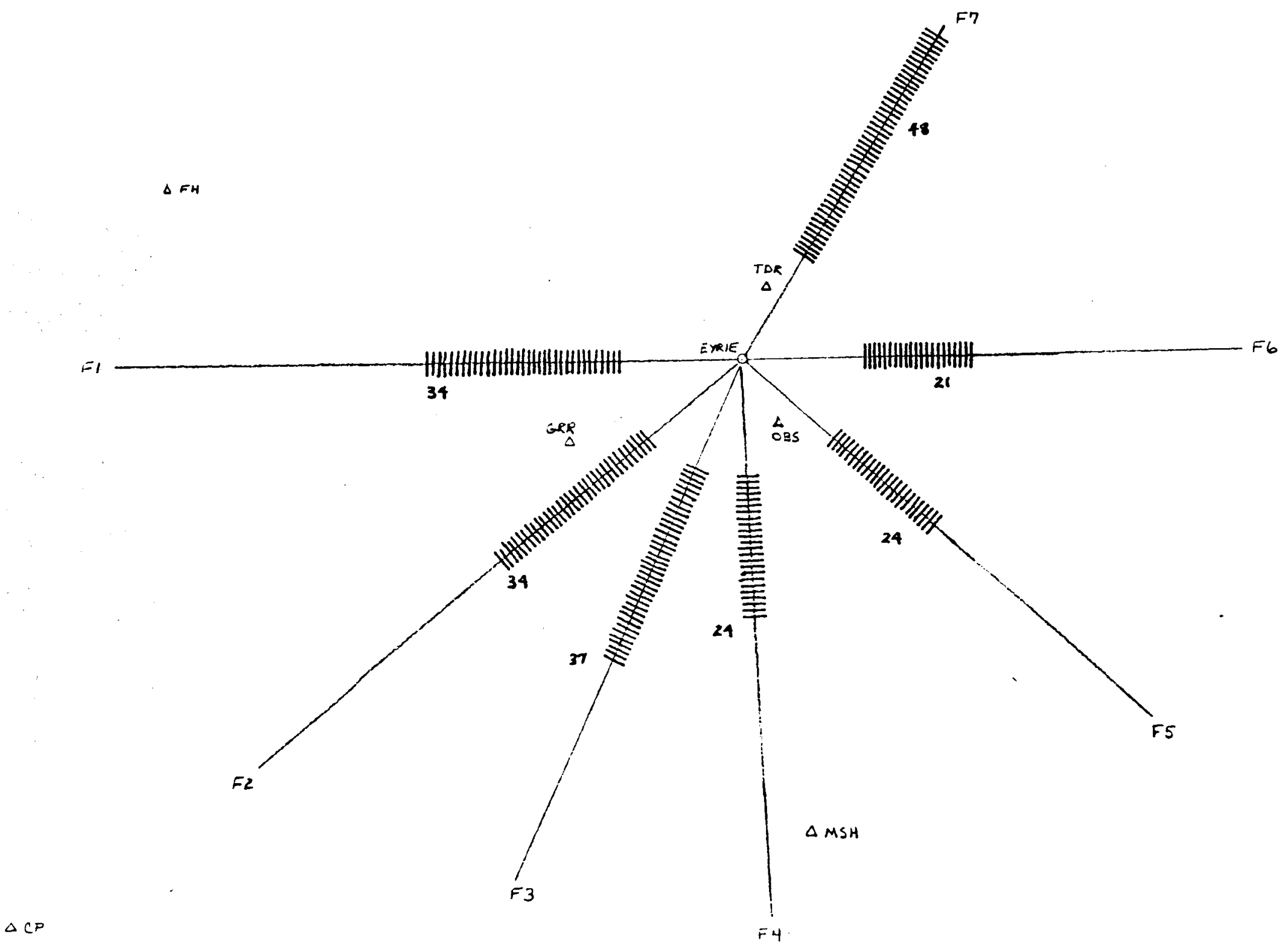

FIGURE 4 Distribution of Flights by Adult Male Seen from Observation Station 3 April - 19 June 1979 


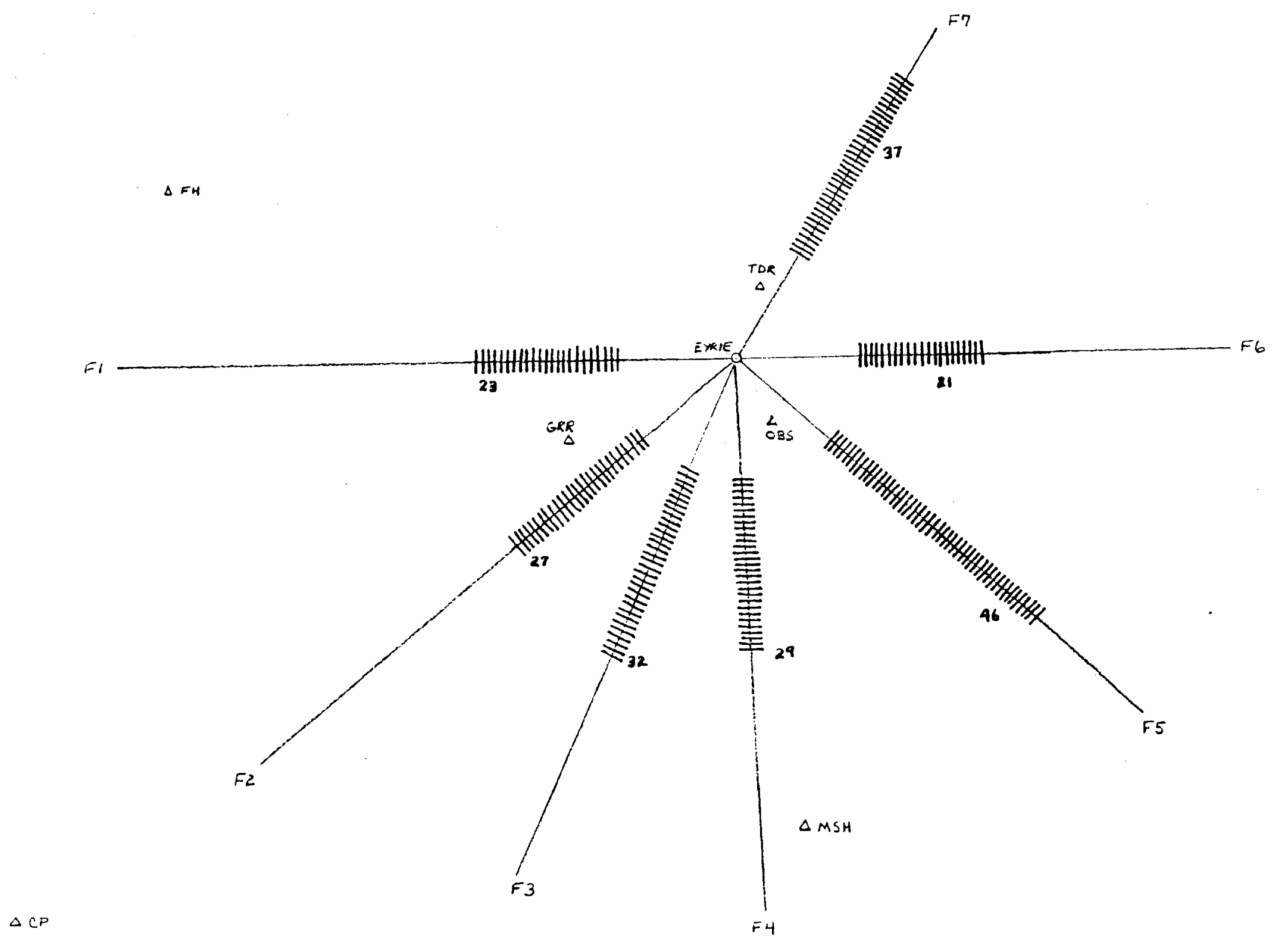

FIGURE 5 Distribution of Flights of Adult Female Seen from Observation Station 3 April - 19 June 1979 


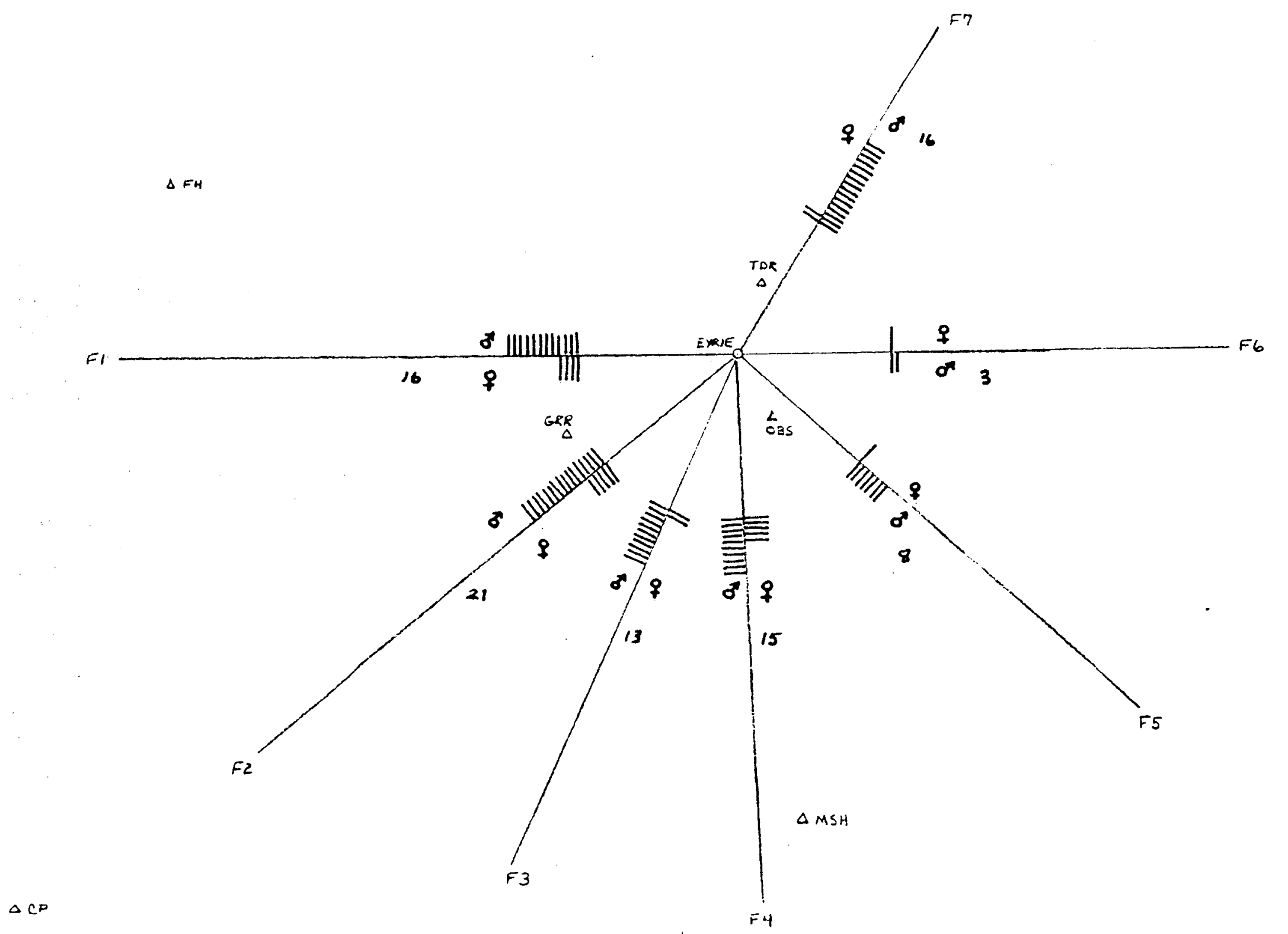

FIGURE 6 Distribution of Inbound Flights with Prey Seen from Observer Station 3 Apri1 - 19 June 1979 


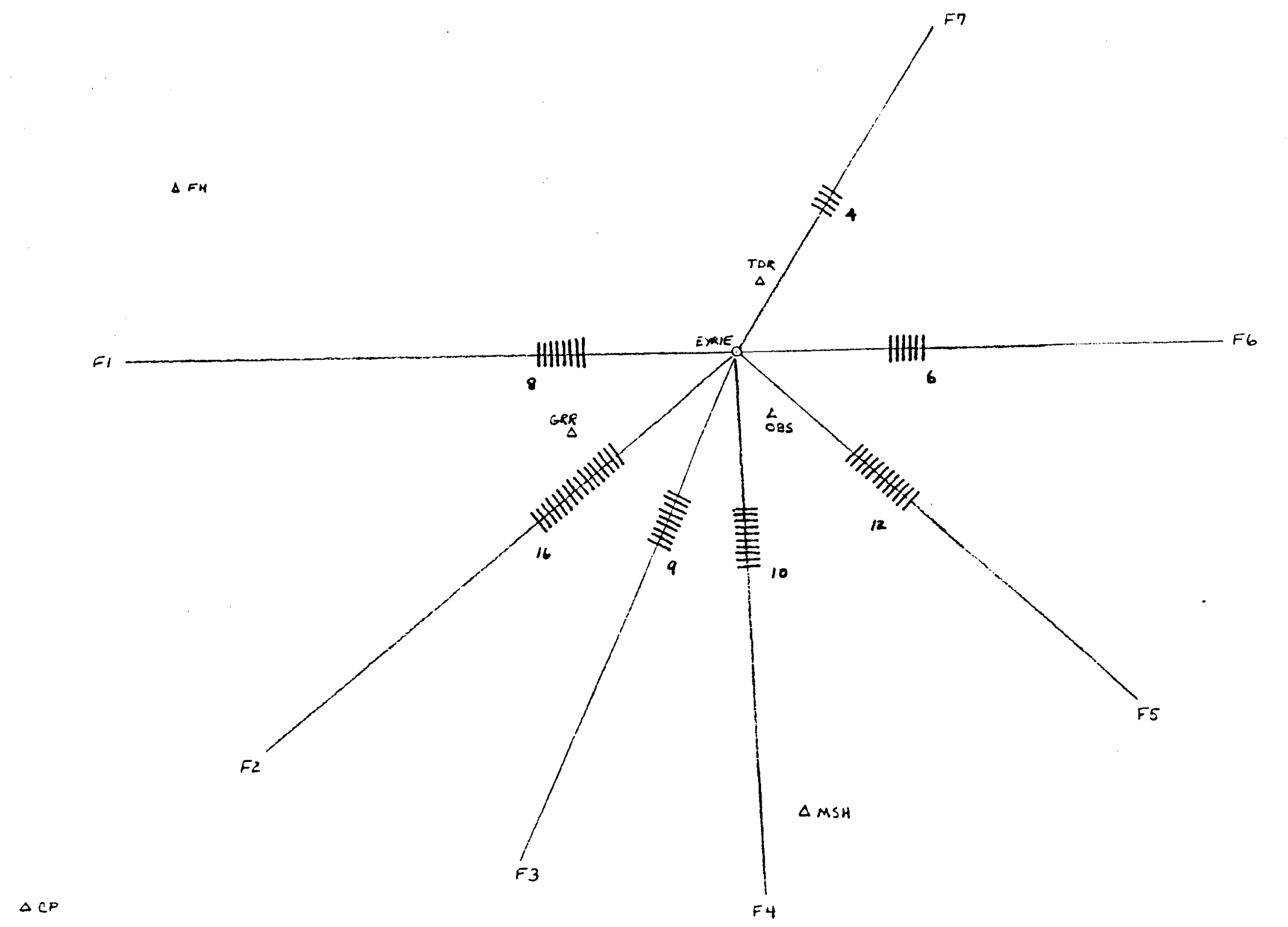

FIGURE 7 Distribution of Flights of Adults Seen from Observer Stations 30 May - 10 July 1978 


\section{II \\ APPENDIX I \\ 1 \\ APPENDIX I}

FIELD WORK SUMMARY

PEREGRINE FORAGING STUDY - 1979

Abbreviations: $M K$ - M. Kirven; JE - J. Enderson; PA - P. Anderson;

$B B$ - B. Braker

17 March MK, D. Harlow, et. al.

male soliciting, female copulation

$1530-1624$ hrs.

24 March MK, S. Boyce

male with kill from SE, food exchange, cache

female tending scrape, no incubation

1 April MK

female incubating; food exchange

$1650-1720$ hrs.

4 April MK

Kirven arranged cabin rental on $M t$. St. Helena (MSH) with D. Sands.

12 April MK, B. Grummer, J. Monk

female flew from eyrie; took B. Bainbridge to guard station.

18 April JE

JE dep COS arr Kirven's 0130 hrs, 19 Aprit

19 April JE, MK, BB, PA

$A M$ - equipment check, met with $B$. Olendorff

PM - Checked Sands cabin, visit Mt. St. Helena telemetry station, obtained keys to gates, secured live owl.

20 April JE, MK, BB, PA

$A M$ - telemetry trials, MSH

PM - trapping attempts in canyon below eyrie;

falcons incubating; transceiver repairs.

21 April, JE, MK, PA

$0930-2030$ hrs.

AM - trapping attempts with bait west of eyrie

PM - trapping attempts with ow 1550 hrs. - caught female, placed transmitter on tail feather male incubating

22 April JE, MK, PA

JE - dep Oakland 1355 hrs.

MK, PA - purchase miscellaneous equipment

23 ApriT. MK, PA

0840 - set up tracking station MSH

$0840-1715$ hrs.

1240 - lock for gate; returned key

1,13 - went to eyrie to contact guard

1030 - went to Forestry office to check access to 2nd tracking station. 
Looked for site for second tracking station

1330 - 1805 hrs.

Charged transceiver batteries; signal from female near Chalk Point (CP).

25 ApriT MK, PA, BB

$0700-1830$ hrs.

0740 - checked access to Pine Mountain for tracking station (TS)

0900 - checked CP and obtained permission to use it as TS.

1400 - checked equipment on MSH - all three receivers checked okay. female at eyrie

1730 - set up equipment at CP

26 April PA, BB

0610 - 1258 hrs.

0650 - $P A$ at $C P$ - no signal, no contact with $M S H$ or guard 0813 - BB set up on MSH, female in eyrie

1250 - heavy rain all morning, female did not leave eyrie.

27 April PA, BB

$1020-1401$ BB at MSH

0925 - 1614 PA at CP

no triangulation data, signals not obtained from $C P$; female in or near the eyrie throughout period received station, and guard, transceiver communications poor.

28 April PA, BB

$$
0900 \text { - } 1945 \text { hrs. }
$$

$A M$ - transceivers to repair shops

PM - transceiver test at MSH and CP, checked okay, no tracking

29 April PA, BB

$0730-1135 ; 1356-1645$ BB at MSH

$0605-1645$

$P A$ at $C P$

transceiver battery failure, corrected at 1356 , no triangulation data, weak signals from female at eyrie from $C P$.

female in or near eyrie throughout period.

30 April PA, MK 1030 - 1900 hrs. entire day spent working on transceivers, purchasing crystals, parts, meters, recharging batteries.

1 May

$\mathrm{PA}, \mathrm{BB}$

0622

$0530-1850$ hrs.

0751 - 1850 BB at MSH

signals from female 1713 - 1834 in rainy weather; no signals received at CP; female was in or near eyrie in period except for one flight to the west and two flights east of County Line Ridge (CLR). 
2 May $P A, B B$

$$
\begin{array}{ll}
1125 \text { - ? } & \text { PA at MSH } \\
1030 \text { - ? } & \text { BB at CP }
\end{array}
$$

telemetry data after 1311 lost; no signal received at $C P$, no notes from $P A, B B$ : data after 1311 missing female at or near eyrie, except for one flight SE over CLR and east of MSH.

3 May PA; BB

Worked on battery packs and transceivers; no tracking.

4 May MK, PA $1000-1800$ hrs.

1000 - 1130 MK went to guard post; female feeding very small young.

1300 - 1800 PA, MK went to MSH, transceiver failed; bought new transceiver.

5 May No field work.

6 May MK, BB $0700-1210 \mathrm{hrs}$.

0745 MK set up at $C P, B B$ at MSH. No signal at $C P$, no tracking data, no guard on duty, transceivers working okay; MK spent PM checking guard whereabouts.

7 May MK $1030-1700 \mathrm{hrs}$.

MK at guard station, rain; female feeding small young and brooding, male hunting, food-transfers.

JE dep. Colo. Springs 1530 - arr. Santa Rosa 2245.

8 May JE, MK, PA, BB $1000-1720$ hrs. Tested triangulation accuracy from $\mathrm{CP}$ and $\mathrm{MSH}$ with transmitter $\pm 3 \mathrm{mi}$. from $\mathrm{CP}$. Signal $185^{\circ}$ from $\mathrm{CP}$, no error; sigñal $228^{\circ}$ from $\mathrm{MSH}, 8^{\circ}$ error yielding an error in position of $0.3 \mathrm{mi}$. Two new RB - $4 \mathrm{~s}$ tested okay on female from MSH.

9 May JE, MK, PA, BB 0730 - 1830 hrs. Attempted to trap male with live owl on Fledging Rock (FR), and on cliff after 1330. "Male made shallow stoop at owl early, but spent day perched on cliff or foraging; female mainly brooding

10 May JE, PA, BB Attempted to trap male with dove and net from $1010-1800$, first on FT and then under eyrie; male tame, no response when dove in view; male hunting, departing $N$ and $S E$, and once NE towards Briggs Crk. 
11 May JE, MK, PA

$0800-1900$ hrs.

Obtained monofilament, 1125 set up net and live owl under eyrie, male made stoop to within $50 \mathrm{ft}$. of it. 1440 placed noose carpet on male's perch in oak - he did not return to perch. Immature female attacked by male.

12 May JE, MK, PA, BB $0700-2045$ hrs. 0950 - JE put two noose carpets on branches in oak on cliff, female did not use either perch entire day, brought in five prey items.

13 May JE, MK, PA

$J E$ dep. for Colo. Springs

$M K, P A$ obtained materials and set $C P$ tracking antenna in concrete; double check compass headings with landmarks.

14 May MK, PA

Set up MSH antenna in concrete $1100-1600$ hrs.

15 May no field work, obtained motorbike for MSH

16 May PA, BB

$B B$ at MSH at 0715; $P A$ set up at $C P$ at 0740 . $B$ Grummer at guard station.

female mainly in eyrie or on ridge from Goat Rock (GR) to Tom Dye Rock (TDR). No signals at CP.

17 May

PA, BB

0630 - 1800 hrs.

$P A$ at $M S H$ at 0700 - no radio contact with guard

(B. Bainbridge); $B B$ at $C P$ at 0930 . Winds $\pm 70 \mathrm{mph}$ on

$M S H$. Female mainly near eyrie and SE over CLR.

18 May MK, PA

0700 - 1730 MK at CP; 0635 PA at MSH

$0415-1730$ hrs. No signals from $C P$, no guard; wind 50-60 mph MSH Female mainly in eyrie, Twin Snags, and two flights SE over CLR.

19 May $M K, B B$

0650 - 1300 MK at CP; 0630 - 1300 BB at MSH

$0600-1300$ hrs.

Female stayed in canyon throughout period.

20 May MK, BB, PA

MK at CP 0700 - 0830; BB at MSH $0700-0800$

MSH antenna found stolen, $B B$ and $P A$ spent day repairing and replacing equipment; MK went to eyrie 1030 with

$S$. Boyce and new guard $P$. Crump. 
21 May JE, BB, MK, PA

0635 - 1430 PA at MSH; $0720-1500$ MK at CP

$0545-1430 \mathrm{hrs}$.

$2330 \mathrm{JE}$ arr.Santa Rosa with BB.

Female at eyrie through period in heavy fog.

22 May JE, PA, BB

$1000-2045$ hrs.

$1205 \mathrm{JE}$ set nooses on oak perch; female caught prey 1815; no birds land in oak; leave nooses in oak.

23 May JE, MK, PA, BB

$0400-1830 \mathrm{hrs}$.

$0535 \mathrm{JE}$ in blind, caught female at 0550; male and female brought in 8 prey items through day. Took nooses down at 1830 .

0805 PA at CP; BB spent AM at MSH fixing blown fuse of transceiver. In PM both stations obtained data; female was SW of CP twice and NW in direction of Briggs Creek once.

24 May JE, PA, BB

$0800-2115$ hrs.

$1330 \mathrm{JE}$ placed nooses in Twin Snags perch after waiting for male to leave area. About 1800 male lands on nooses but not caught. Female made 2 kills, male at least 3 .

$25 \mathrm{Ma}$

JE, MK, PA $0400-1830$ hrs. $0520 \mathrm{JE}$, PA in hide under snags, male did not land there all day. Female caught 2-3 prey, male 4-5 prey.

26 May JE, MK, BB

JE dep. for Colo. Springs

$0800-1730$ hrs. 0900 MK at $C P$, no signal all day. $0930 \mathrm{BB}$ at MSH, returned to cabin since AVM supplied wrong receiver cable, set up at 1200 . Female active in PM in Rattlesmake Canyon (RC) and once over CLR. No triangulation data.

27 May MK, BB 0615 - 1700 hrs.

0730 - 1700 MK at CP; 0715 - 1700 at MSH, very windy Female spent day near eyrie and near CLR. Direction to test transmitter from $\mathrm{MSH} 215^{\circ}$ - near perfect.

28 May MK, PA

0605 - 1800 PA at MSH

0722 - 1800 MK at CP

no signals received at $C P$;

29 May PA, BB 0545 - 1900 hrs.

0955 - 1900 PA at MSH, too windy to set up earlier 1030 - $1830 B B$ at $C P$

Female spent all of the time near eyrie or $E$ to SE. 
30 May

$\mathrm{PA}, \mathrm{BB}$

$0810-1700$

$0900-1830$
$P A$ at $C P$ too windy to track $A M$

$0700-1700$ hrs.

$B B$ at $M S H$

No signal from $C P$; female in area of eyrie most of PM
31 May PA, BB, JE

0610 - 1910

$0745-1900$

2335 JE arr. Santa Rosa.

$B B$ at $C P$

$P A$ on $M S H$, high winds

$0530-1910 \mathrm{hrs}$.

transceivers inoperable apparently 2 -foraging flights to $\mathrm{NW}$ and 2 to SE

1 June JE, MK; PA

1110 - 2115 JE put 4 noose rigs on male's perches on

0645 - 2115 hrs. cliff; antenna not showing on female, signal very weak; male landed on or near nooses 2-3 times - not caught.

2 June JE, MK, PA

0400 - 1830 hrs.

$0700 \mathrm{JE}$ re-arranged nooses on preferred ledge, male kicked nooses off ledge at 0945 .

1520 caught male.

3 June $M K, P A, B B, J E$

0930 JE dep. Santa Rosa, arr. Colo Springs 2100

0730 - 1340 PA at CP; 1000 - 1300 BB at MSH

1535 - $1930 B B$ at $C P$.

1620 - 1915 PA at MSH

transceiver breaks down, no tracking communications

1240 - male flew far to $W$ of $C P$; MK brought new transceiver equipment, 2000 - 2030 meeting on equipment.

4 June MK, PA

0550 - 1900 PA at MSH

$0550-1900$ hrs.

0615 - 1700 MK at CP

fog until 1000 hrs., no movement of male until then.

Male made 2 flights SE; $2 \mathrm{~N}$ (spent $30 \mathrm{~min}$. in

Briggs (reek area), and one down Napa Valley to south.

5 June MK, PA

$$
\begin{aligned}
& 0900-1850 \\
& 1000-1700
\end{aligned}
$$

PA at MSH

$0830-1850$ hrs.

MK at $C P$

Male made three flights to Briggs Crk. area, two to Knight's Valley (one $S$ and one $W$ ).

6 June $P A, B B$

$0730-1725$

$1430-1700$

$\mathrm{PA}$ at $\mathrm{MSH}$

$0700-1725$ hrs.

$B B$ at $C P$

Male made two flights north of eyrie ridge, one east, and one SW (triangulation). 


\section{II \\ APPENDIX I \\ 7}

7 June $M K, P A, B B$

$0600-1825$

$?-1400$

$1400-1800$

$\mathrm{PA}$ at MSH wind $70-80 \mathrm{mph} \mathrm{MSH}$

$0530-1825$ hrs.

$B B$ at $C P$

MK at $C P$

Winds too high until 1240; then no signals

(transmitter failed)

$\begin{array}{ll}8 \text { June } & \text { MK, PA } \\ & 0600 \\ & 0630-0700\end{array}$

wind 70-80 mph MSH 0530 - $1630 \mathrm{hrs}$.

MK set up test transmitter

MK at CP; 0800 MK at MSH: 1130 MK arr. eyrie

MK got no signal from male, antenna missing;

female gives weak signal

22 June JE - re-worked transmitters, nooses, equipment.

23 June JE - dep. Colo. Springs 0900 - arr. Kirven's 0315

24 June JE, MK, PA 0730 - $0730 \mathrm{hrs}$.

0830 arr eyrie, set 5 sets of nooses; 1645 caught one of 3 males

25 June JE, PA

0710 -

$0600-2000$ hrs.

Set four noose sets; caught 2 nd male at 0815

26 June $J E, P A$

0800 -

$0600-0830$ hrs.

5 noose sets ready; 1000 discover 2 nd transmitter not working; tried dead owl, adult male stooped several times.

27 June JE dep. Santa Rosa 1000 - arr. Colo. Springs 1800.

28 June $P A$

$1536-1540$

$1430-1630$ hrs.

PA at MSH loud signal, remaining instrumented young probably on CLR.

29 June $P A$

0930 - MSH; signal, young around TDR.

30 June PA MSH;

1630 - 1740 no signal;

1740 - 1745 good signal from TDR

1 Juty PA

the tagged young flew south, and west of MSH;

$1630-1759$ hrs.

seen with 2 other young three times, once at MSH station.

2 July PA

0749 - 0800 hrs.

the young is at eyrie, good signal. 
3 July PA weak signals from the eyrie area

4 July PA weak signals from the eyrie area

5 JuTy PA Young male flew SW of MSH station and NE of station, both times at no great distance since transmitter is weak.

6 July PA

No signal.
0805 - 1005 hrs.

0836 - 0912 hrs.

$0615-0800$ hrs. 
APPENDIX II

\section{PLOTTINGS OF TELEMETRY BEARINGS \\ FOR RADIO-TAGGED FALCONS}

Shown are plottings by date of all bearings for the adult female ( 27 April-31 May), adult male ( 3 June-6 June) and one young male (29 June-1 July) made from overlays of the Mount St. Helena 7.5 minute quadrangle sheet. Bearings are shown as lines drawn in the direction of the signal from either of the two tracking stations. Numbers on bearing lines indicate time of observation.

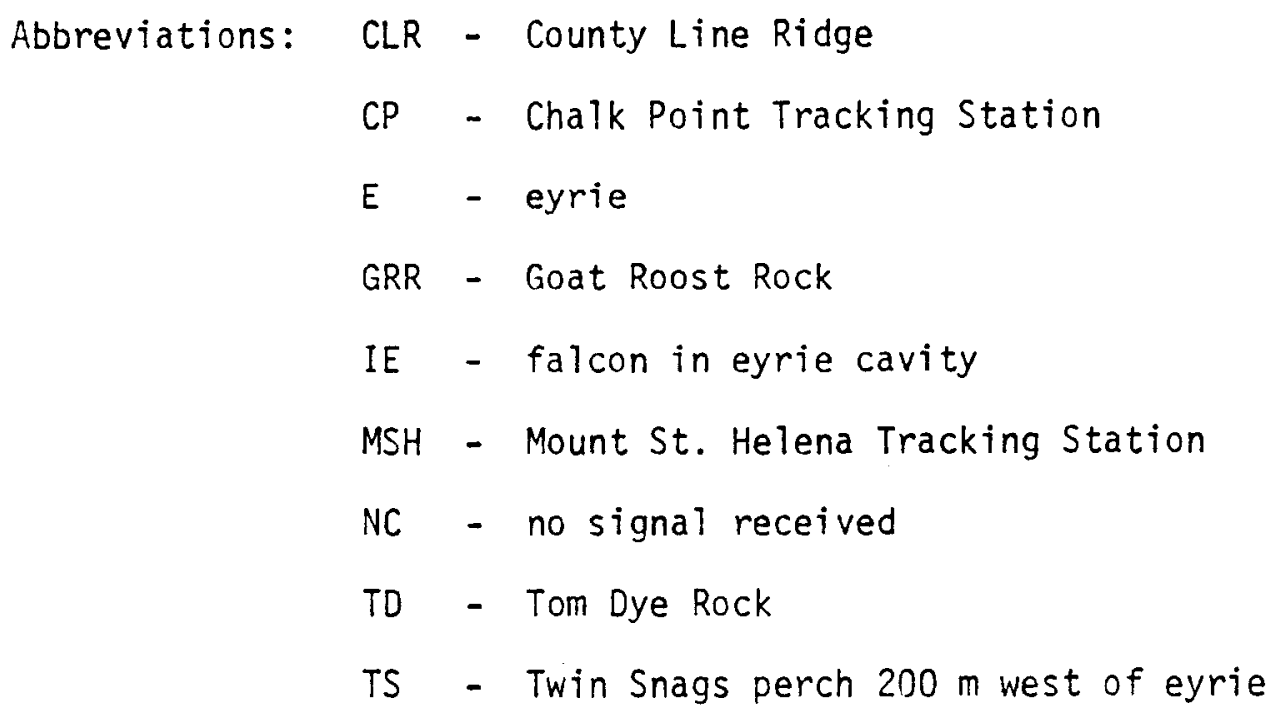

Scale: 1 inch $=0.75 \mathrm{~km}$ 


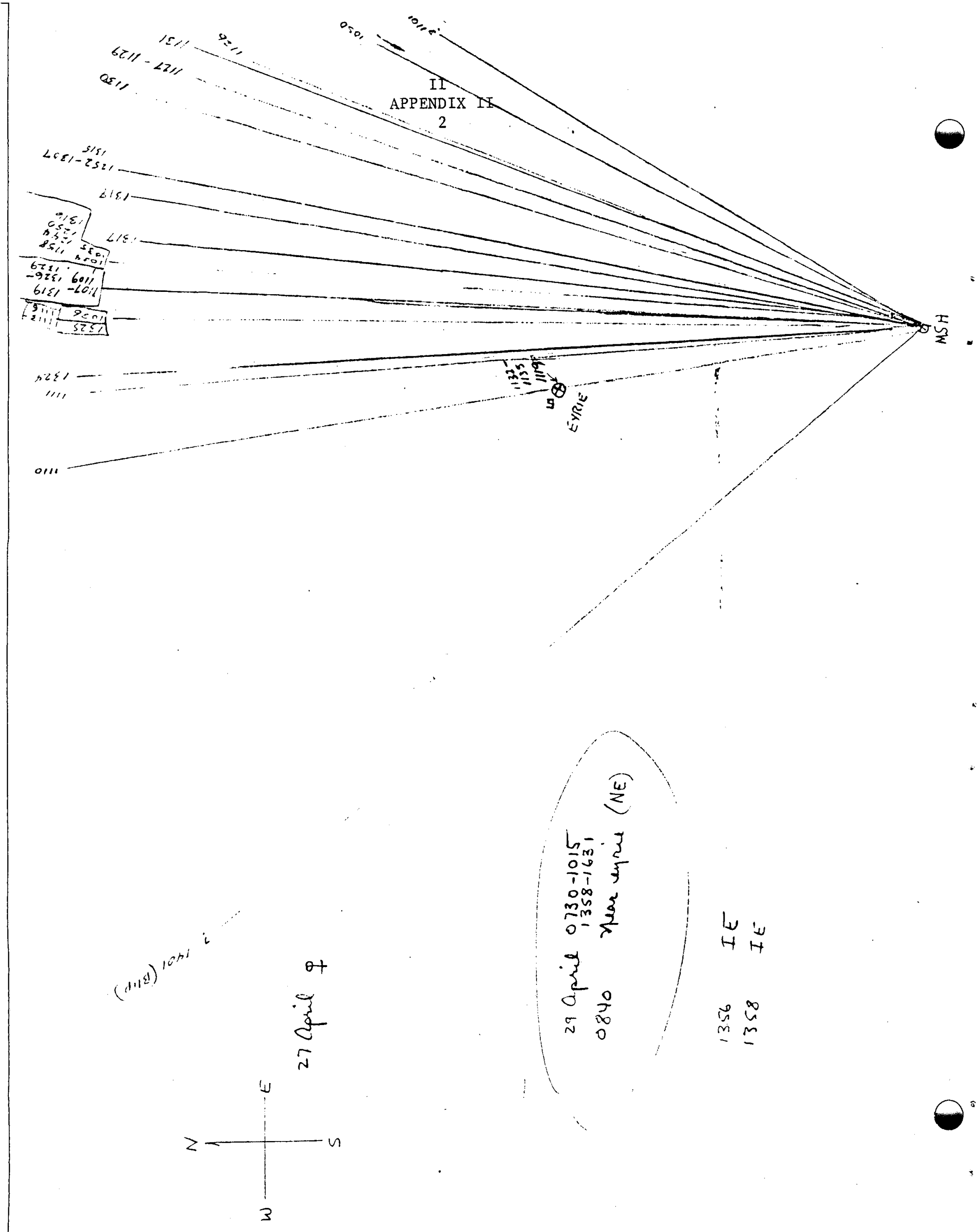




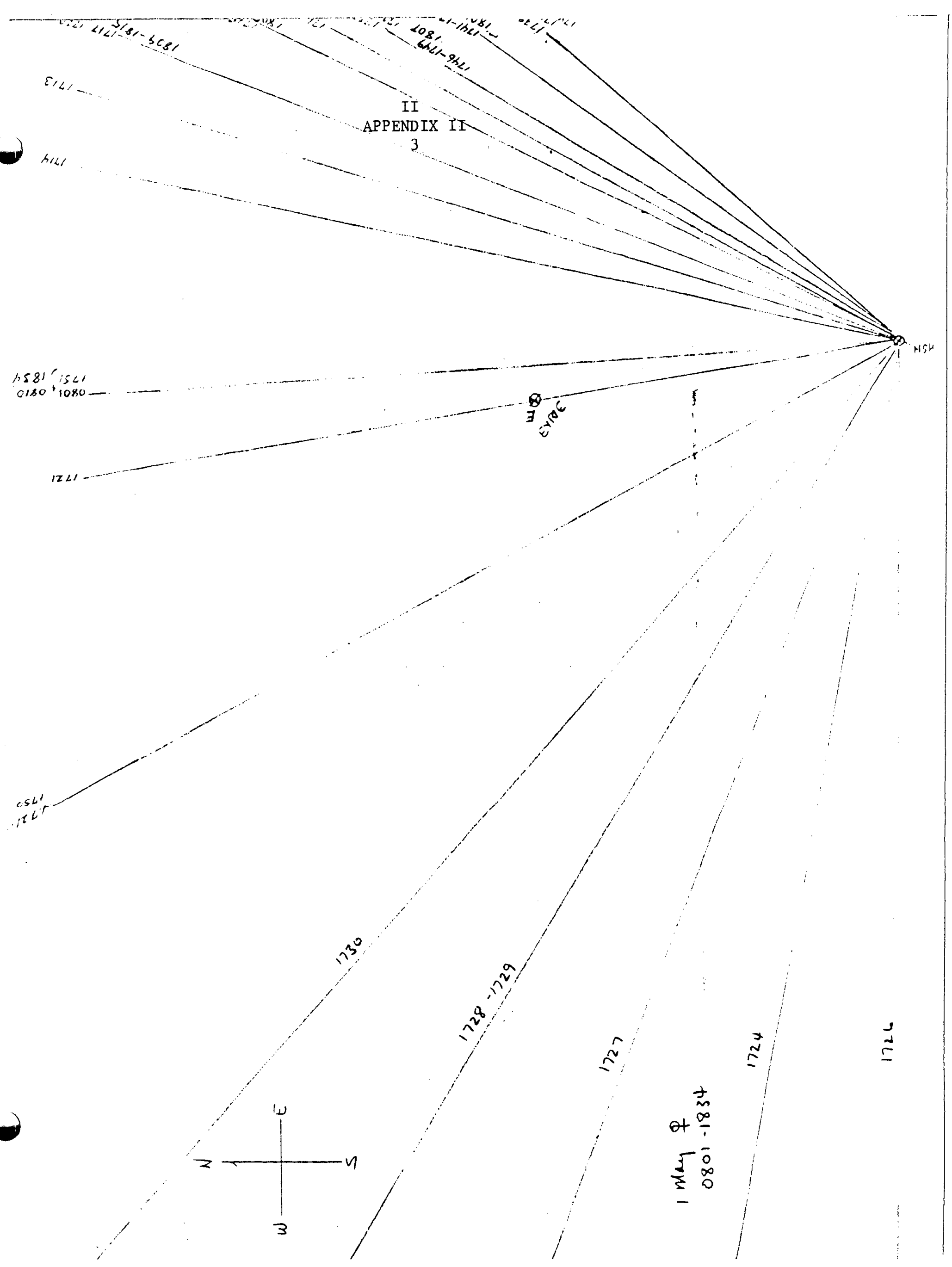




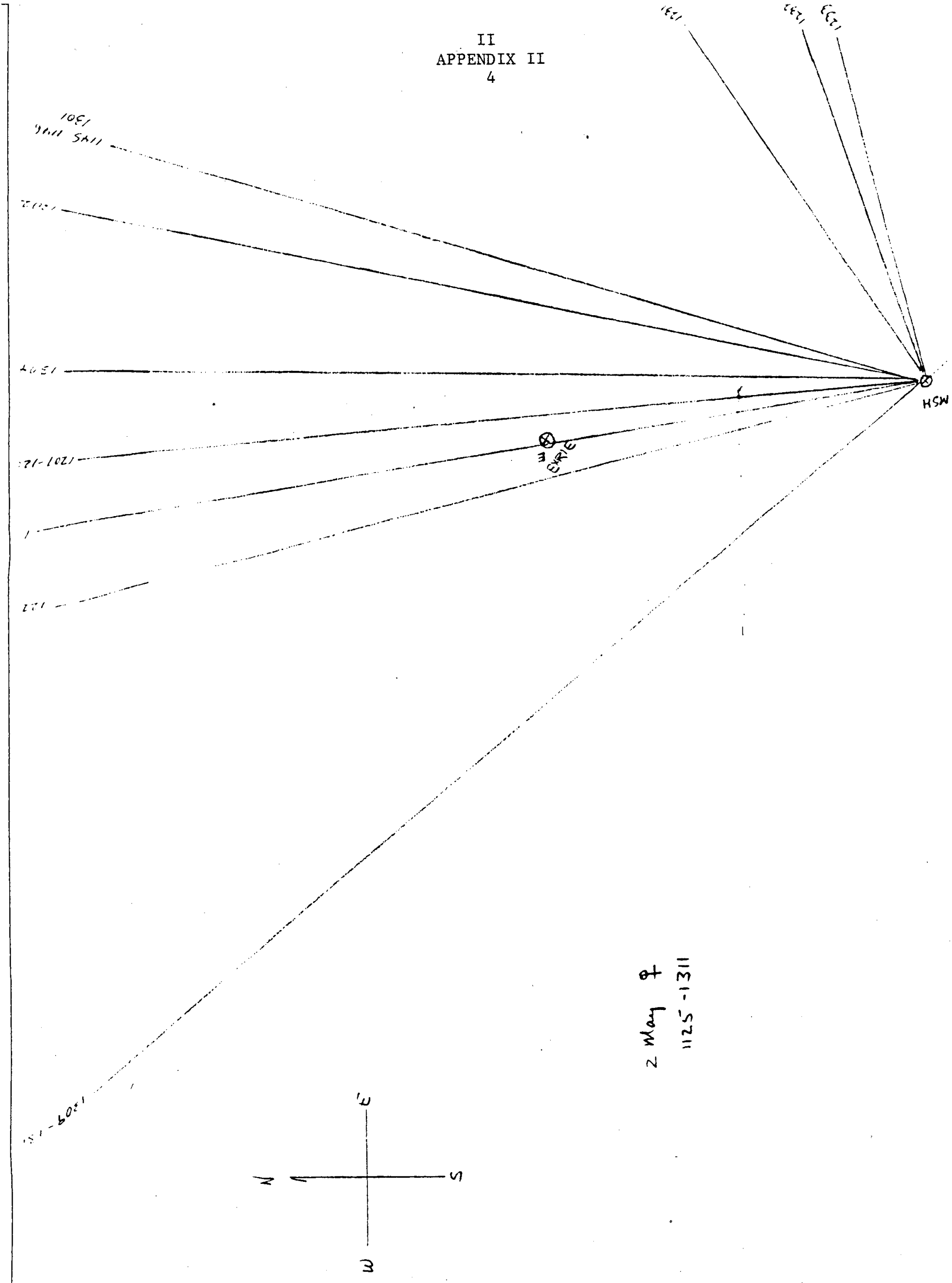


$(2,2)$
$i \infty 0$,
$i=0$,

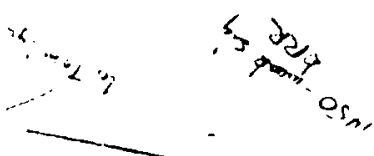

20

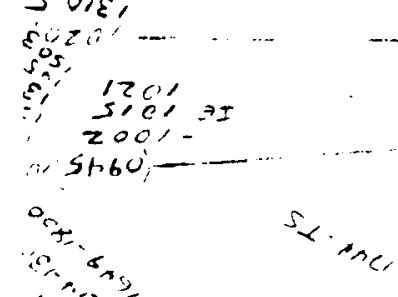

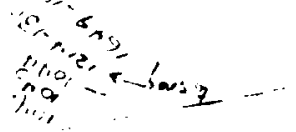
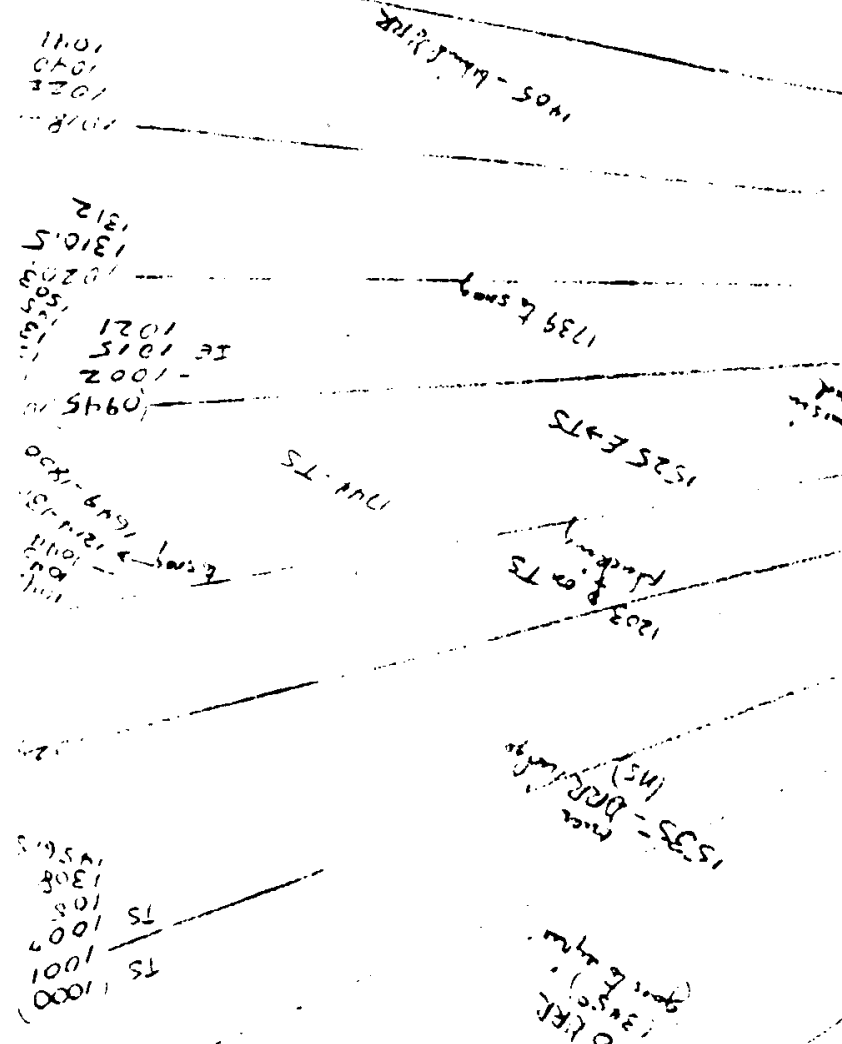

$\ln _{0}^{3}$
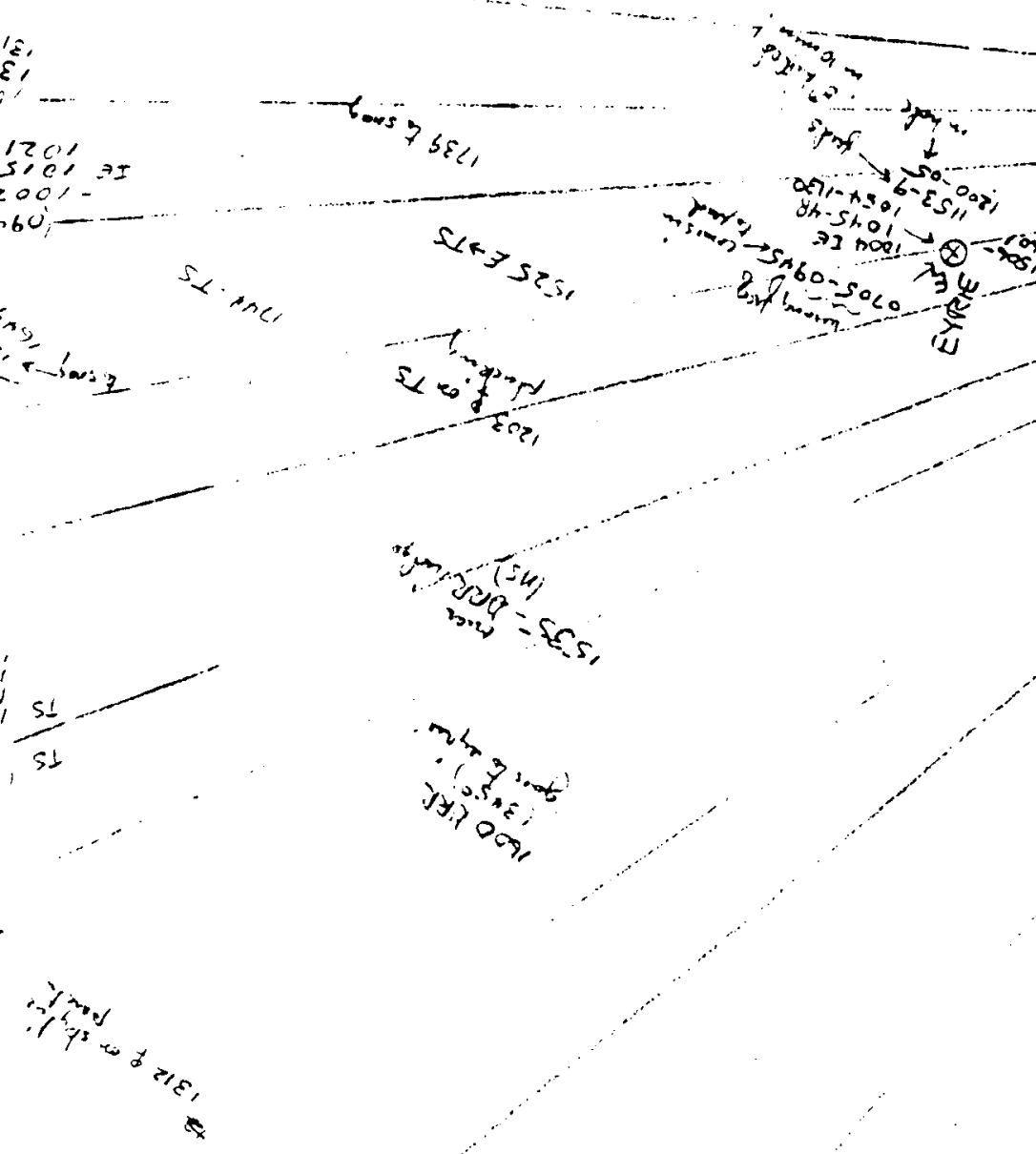

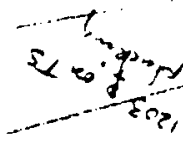

$1,-50<0$ -
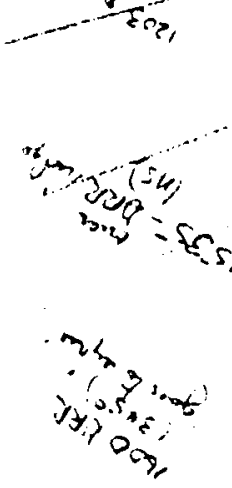

, se

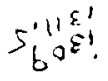
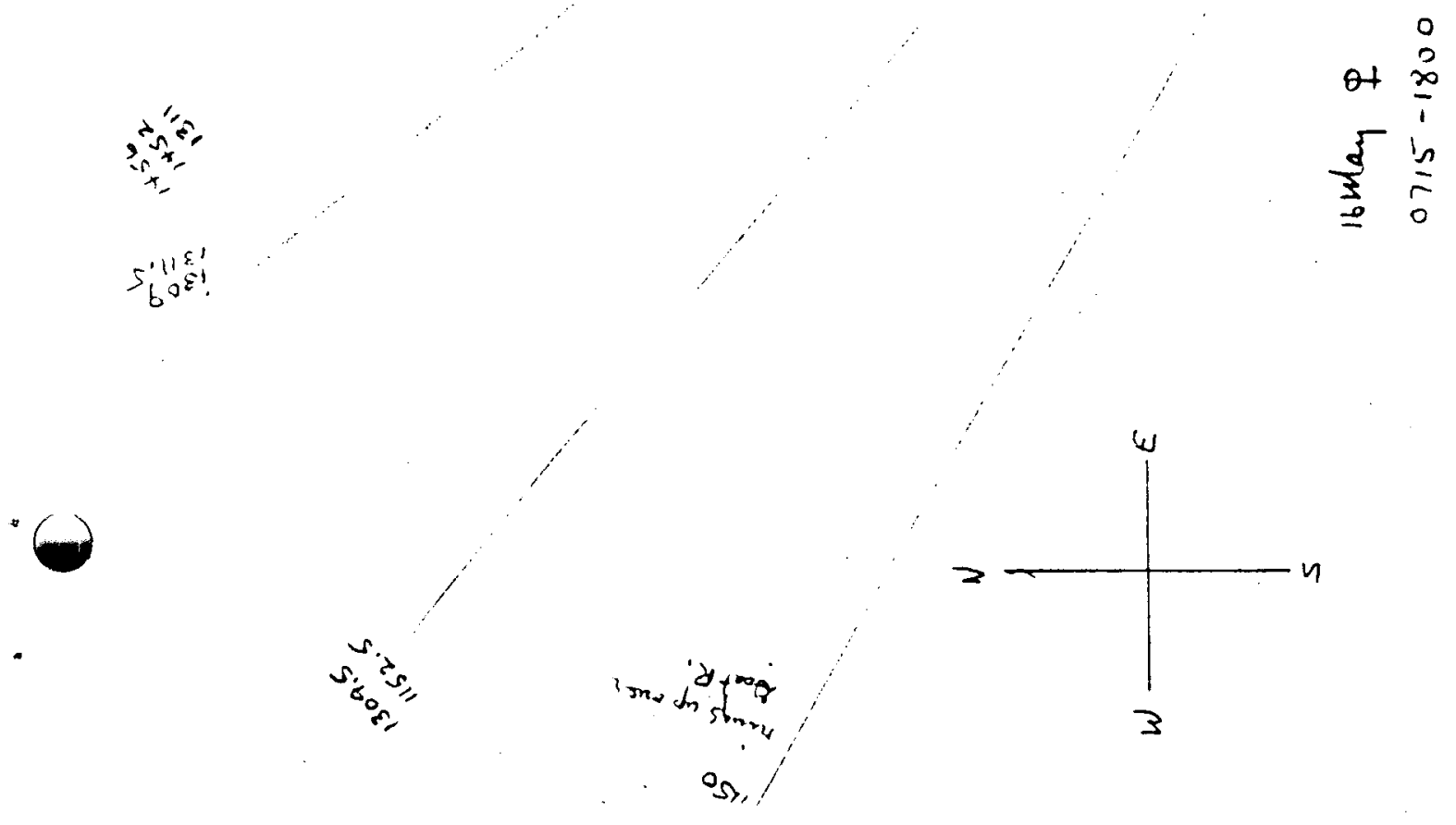

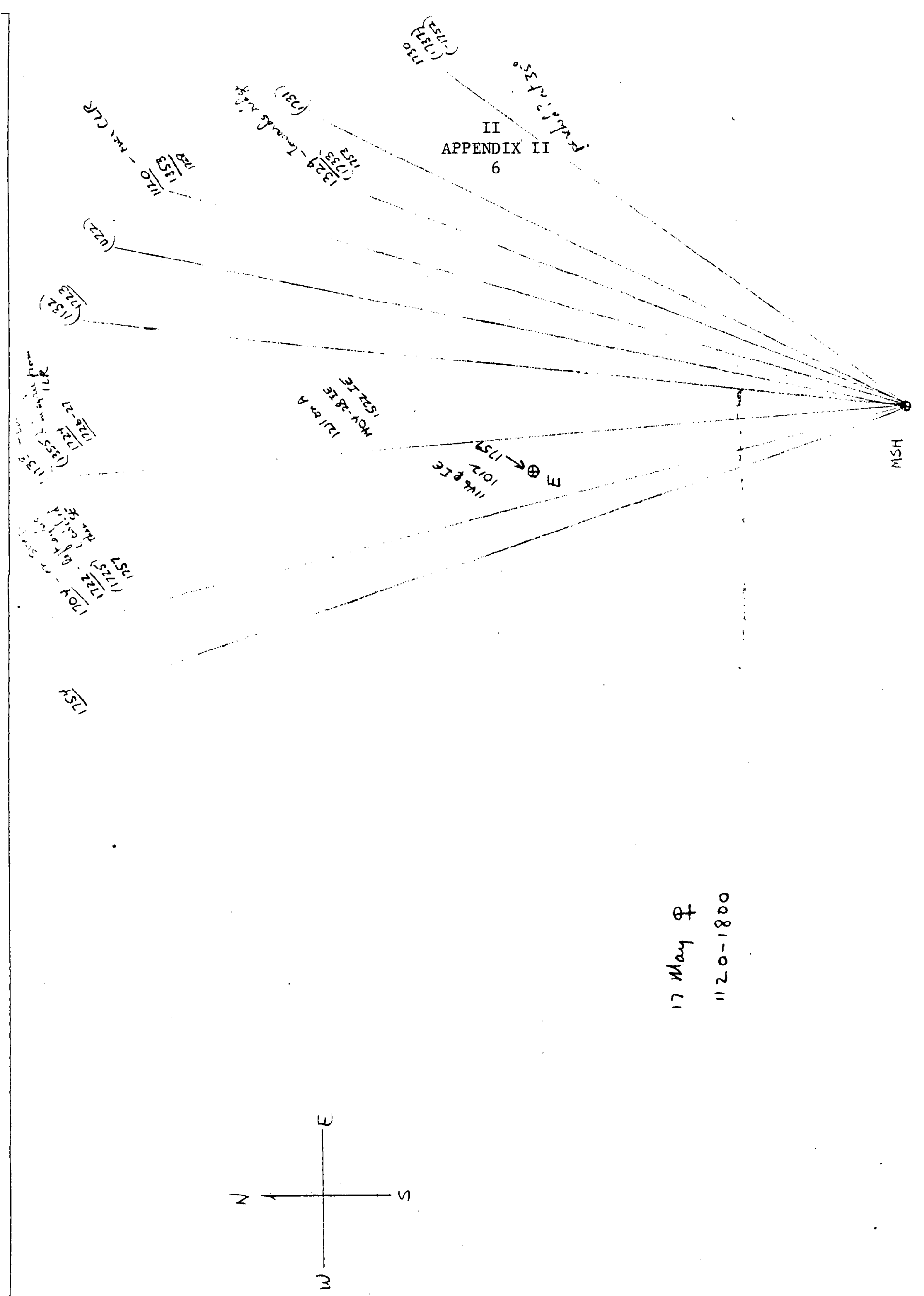


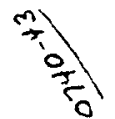

مొ
II

APPENDIX II

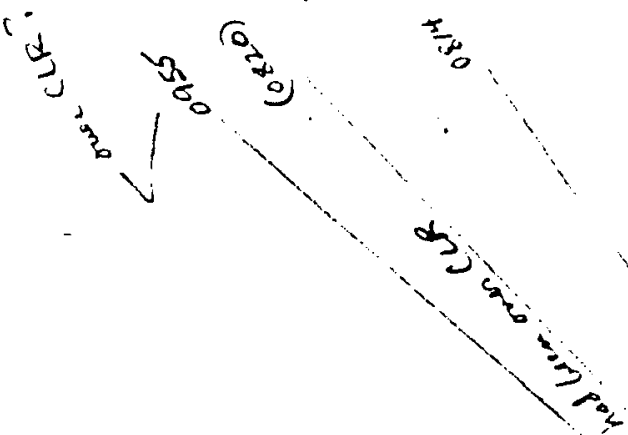

7)
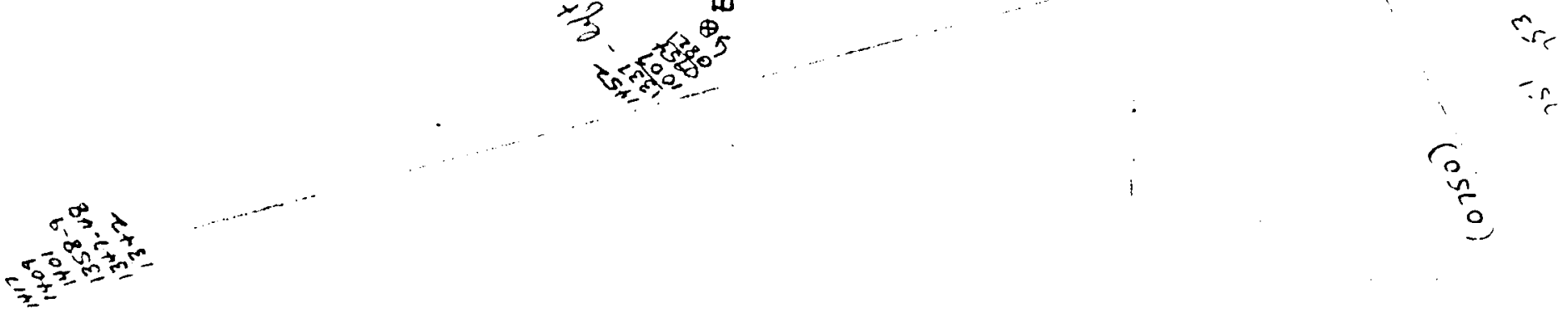

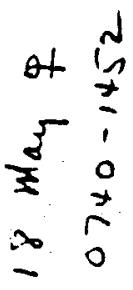

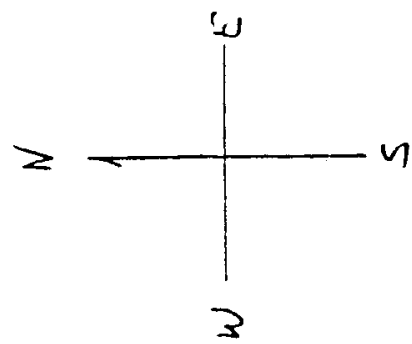

$\stackrel{2}{0}$ 


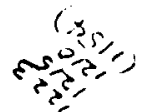

$$
{ }^{n} x_{0}>\oplus W
$$

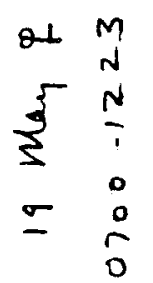

$\stackrel{1}{\omega}$

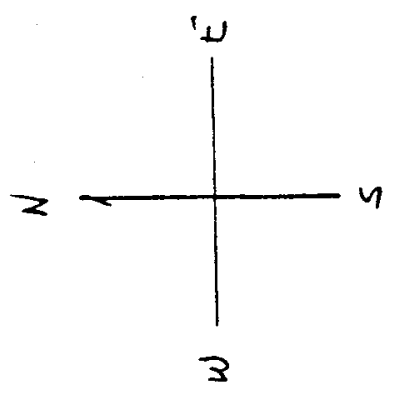




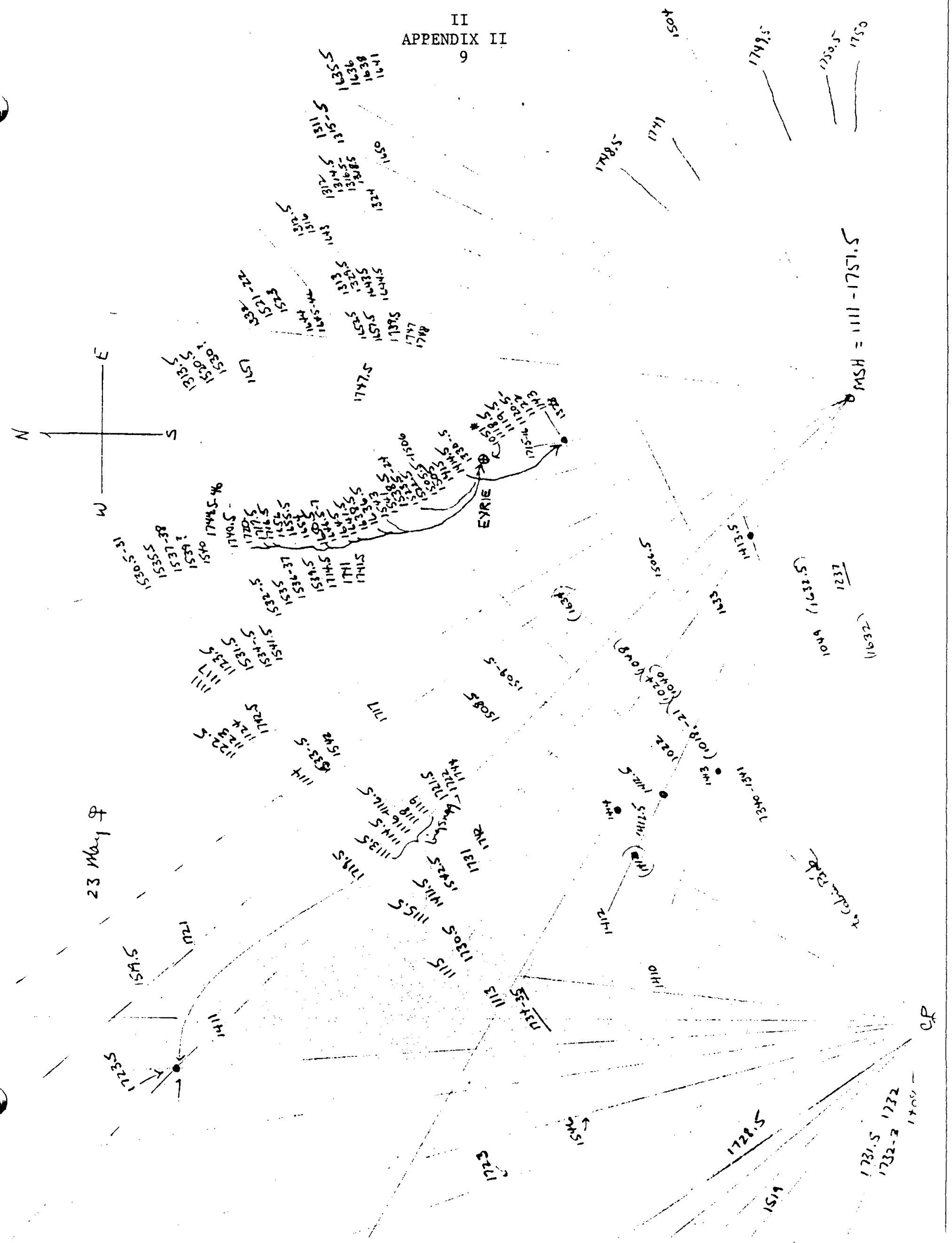




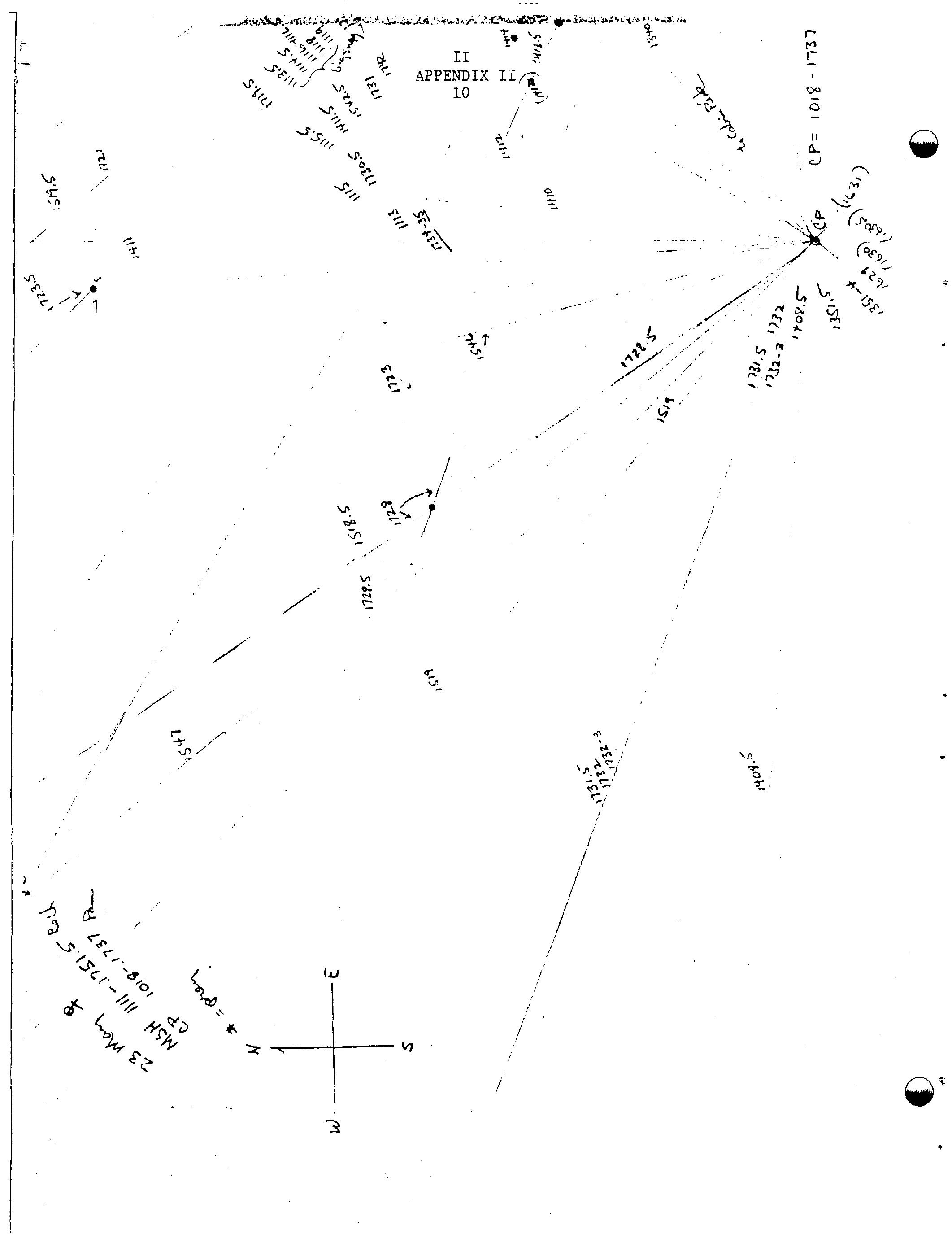




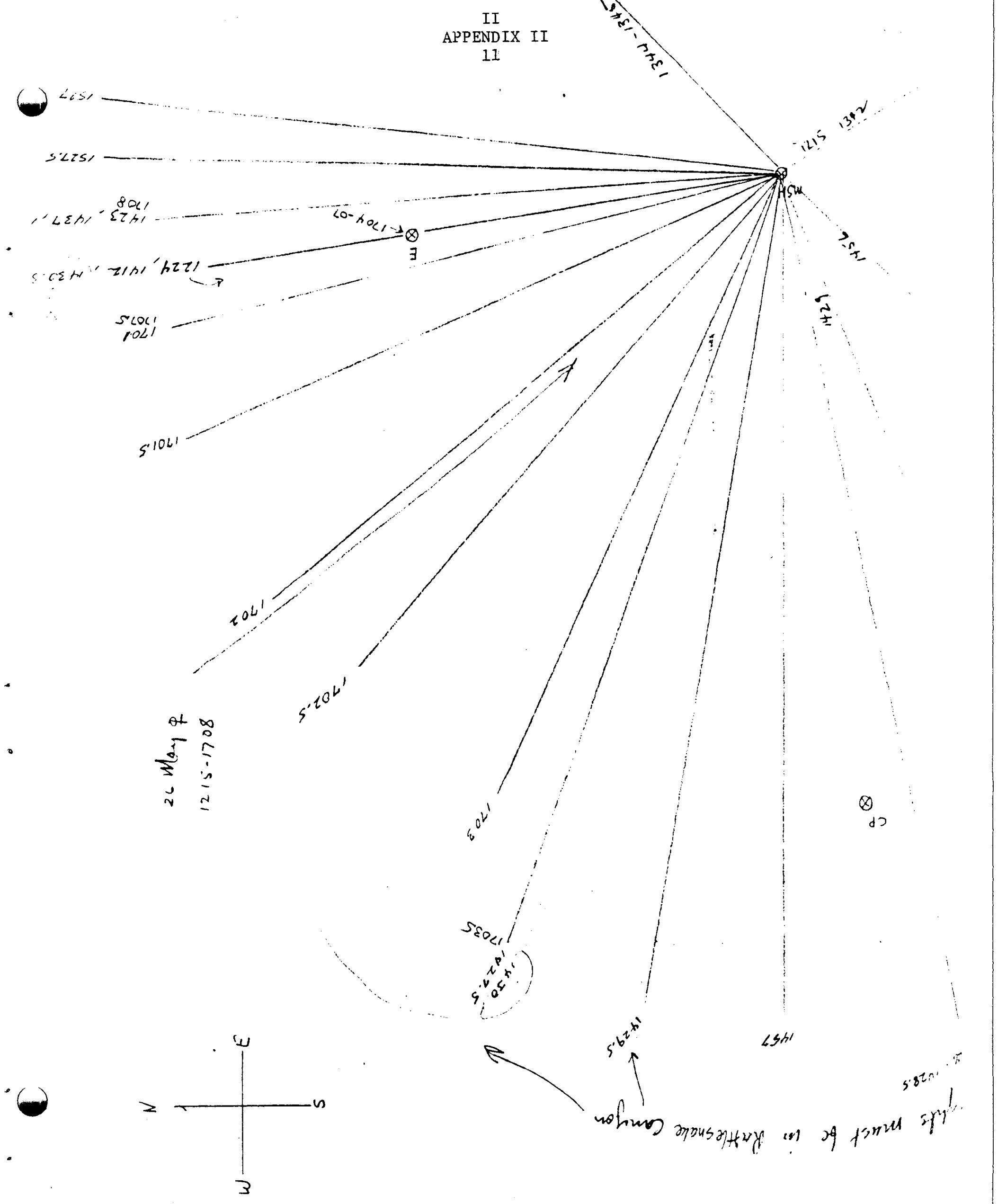



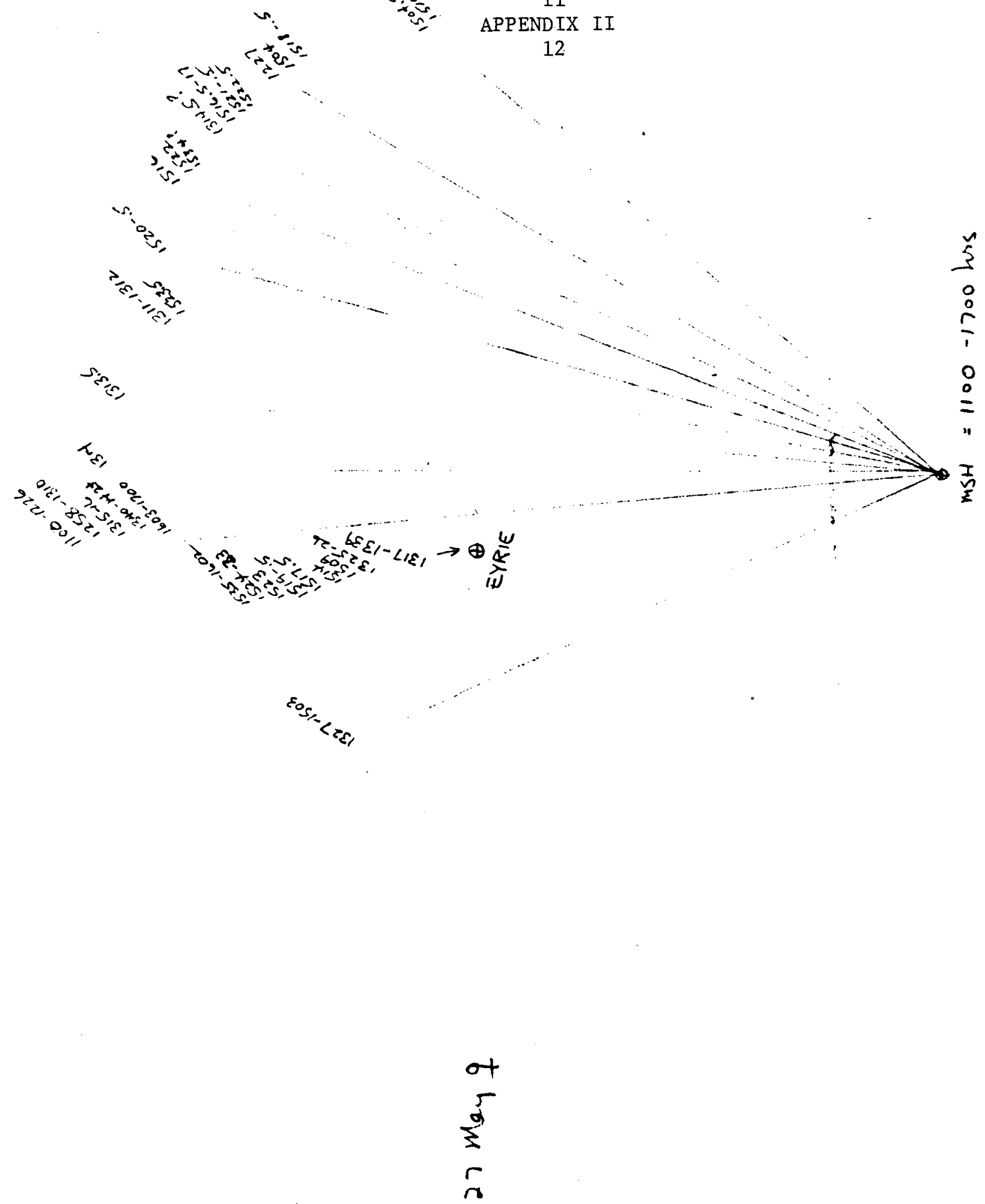

$\stackrel{\Omega}{\oplus}$

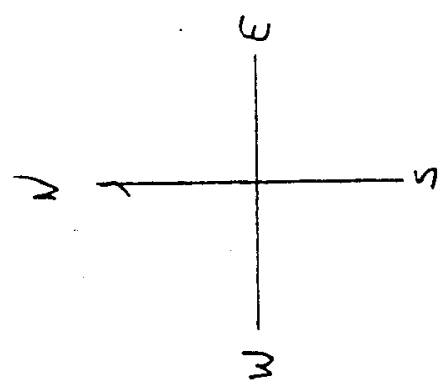




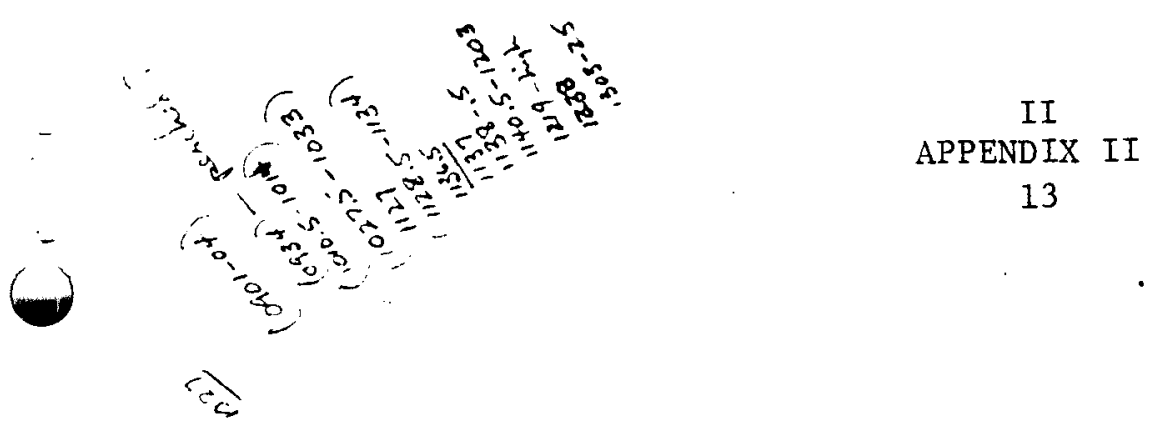

s)$$
\text { sijas? }
$$$$
\text { a. }
$$

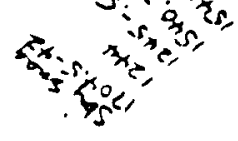

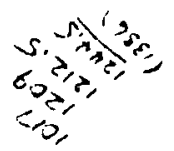

$$
\text { isis: }
$$

$\Sigma$ 

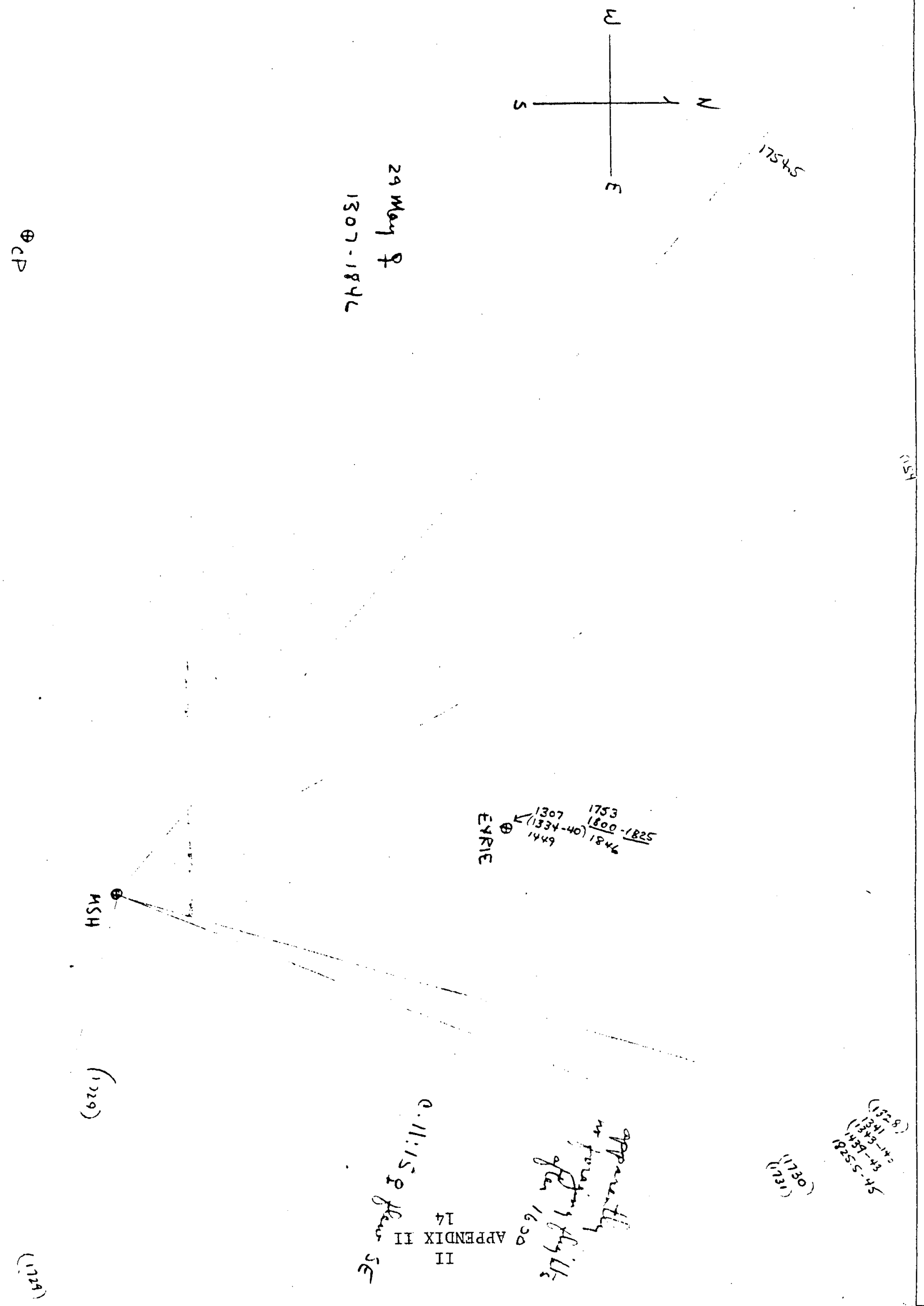
II
APPENDIX II

II
APPENDIX II
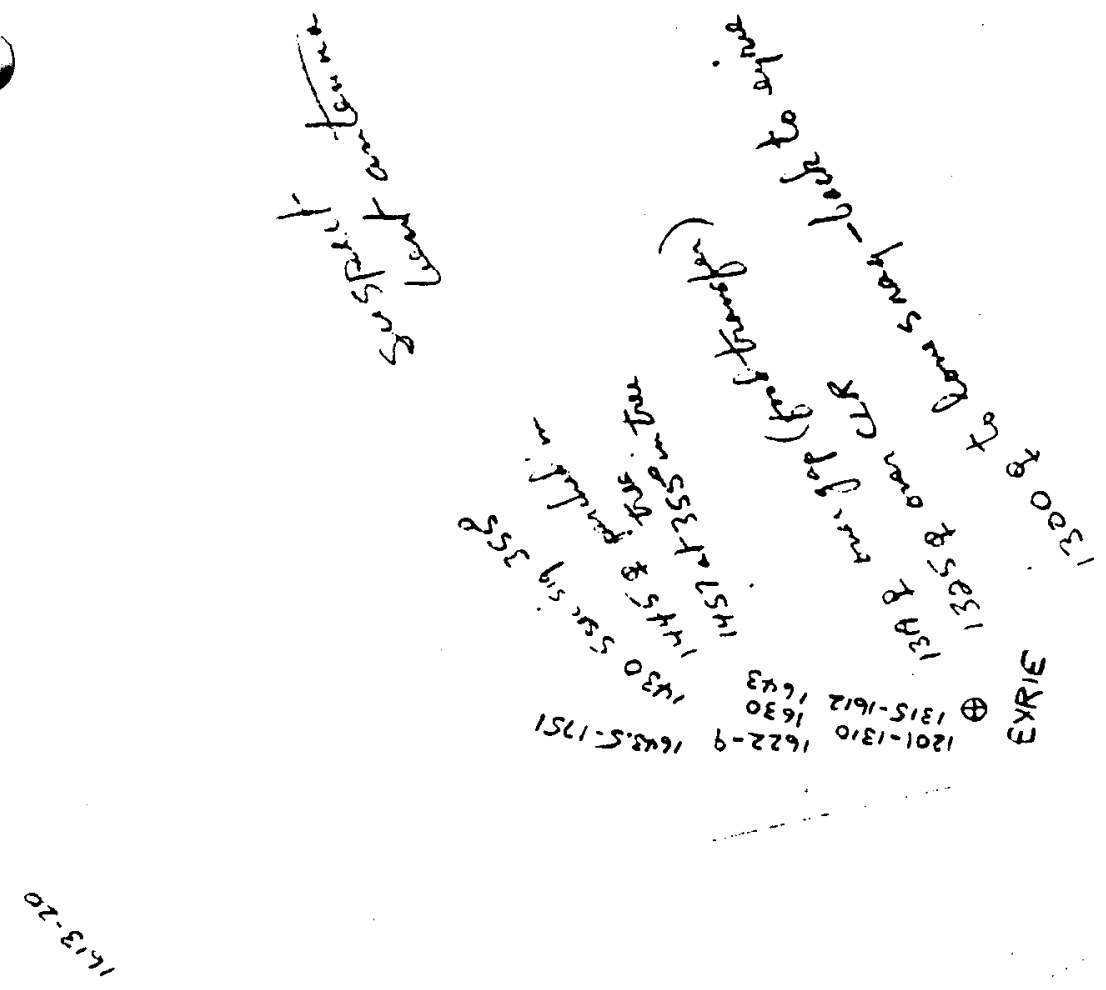

$\infty^{ \pm}$

$\stackrel{s}{\dot{x}_{y}}$

3,2
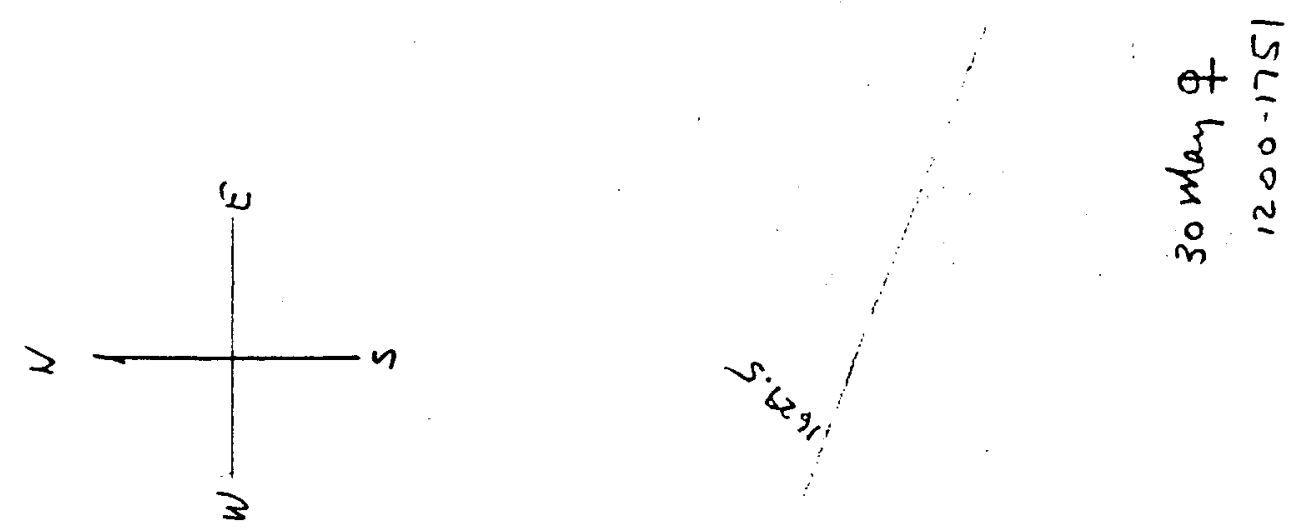

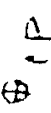




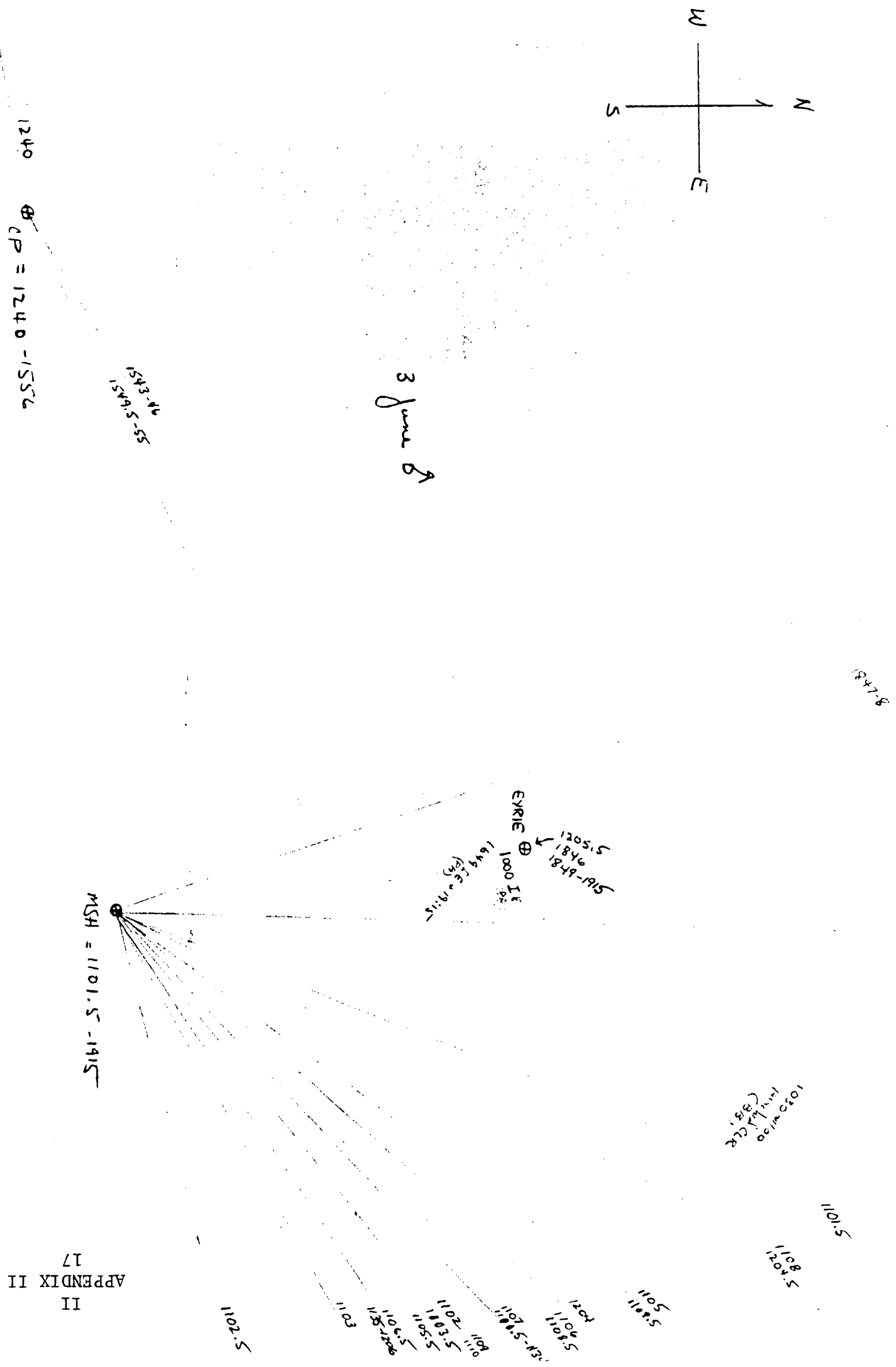

.

.
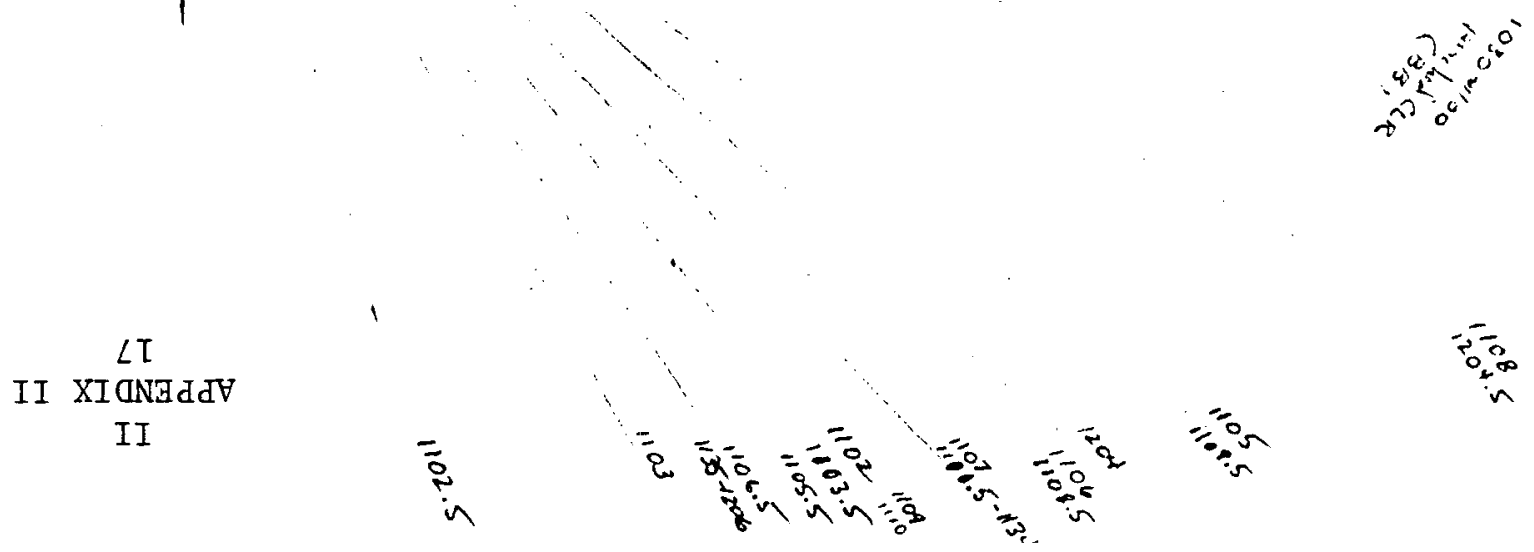


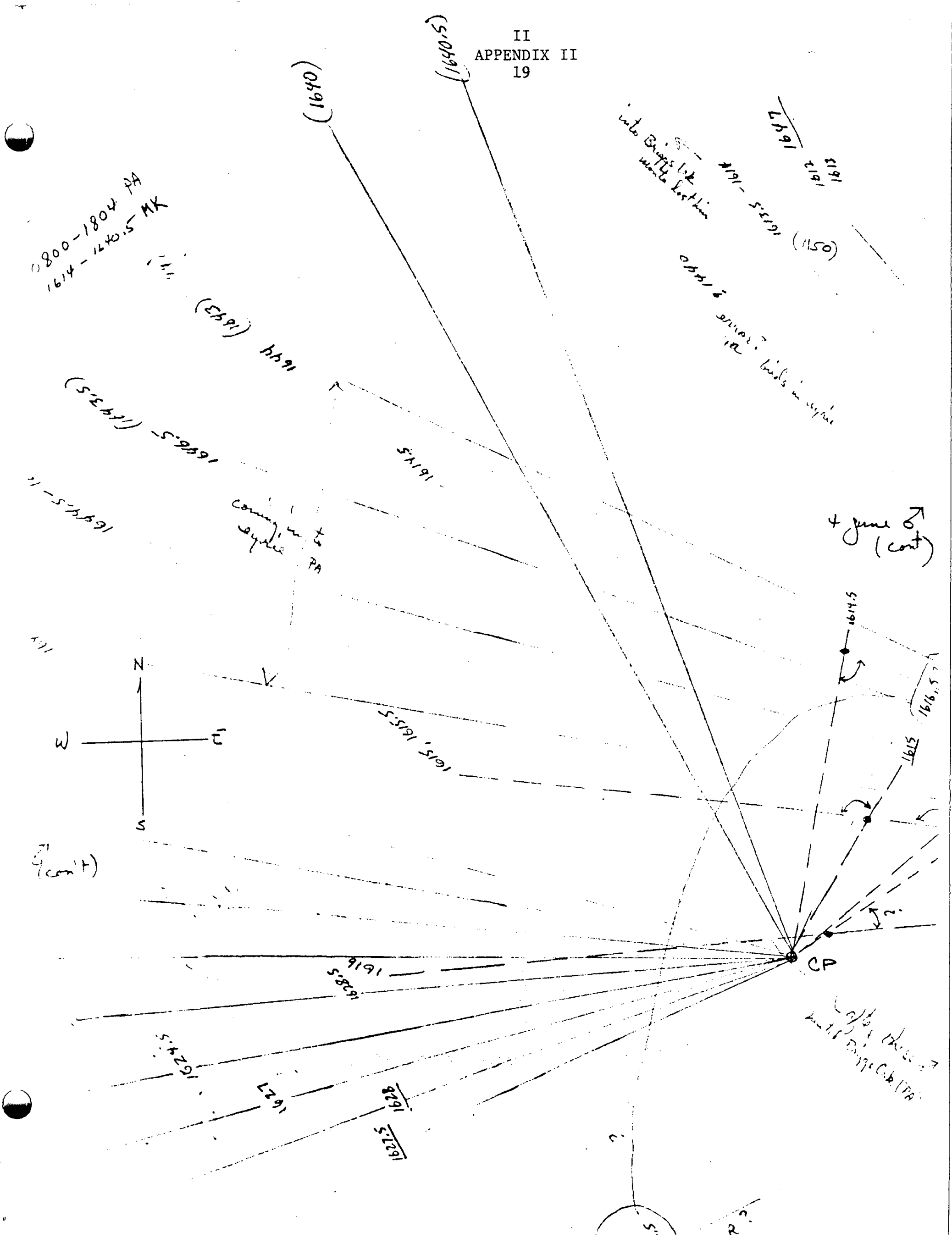




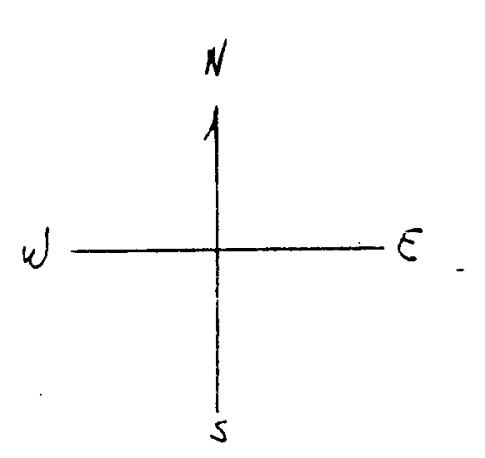

II
APPENDIX II

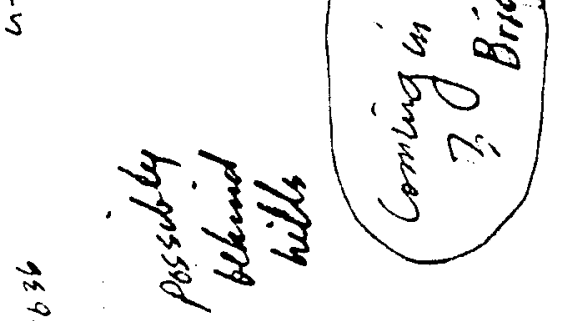

$\stackrel{3}{0}$

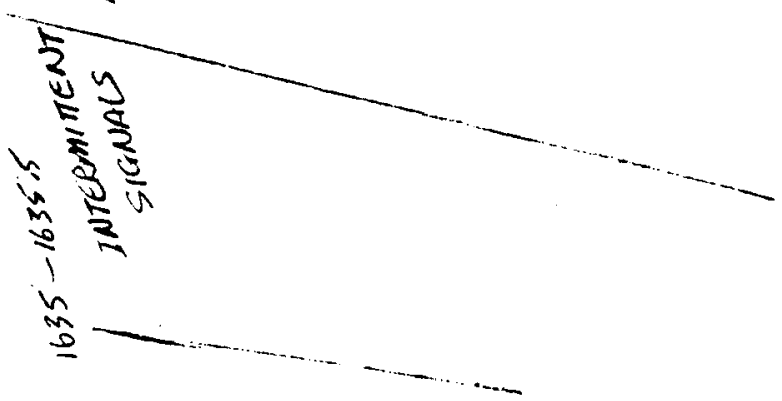

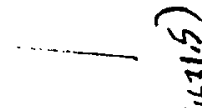
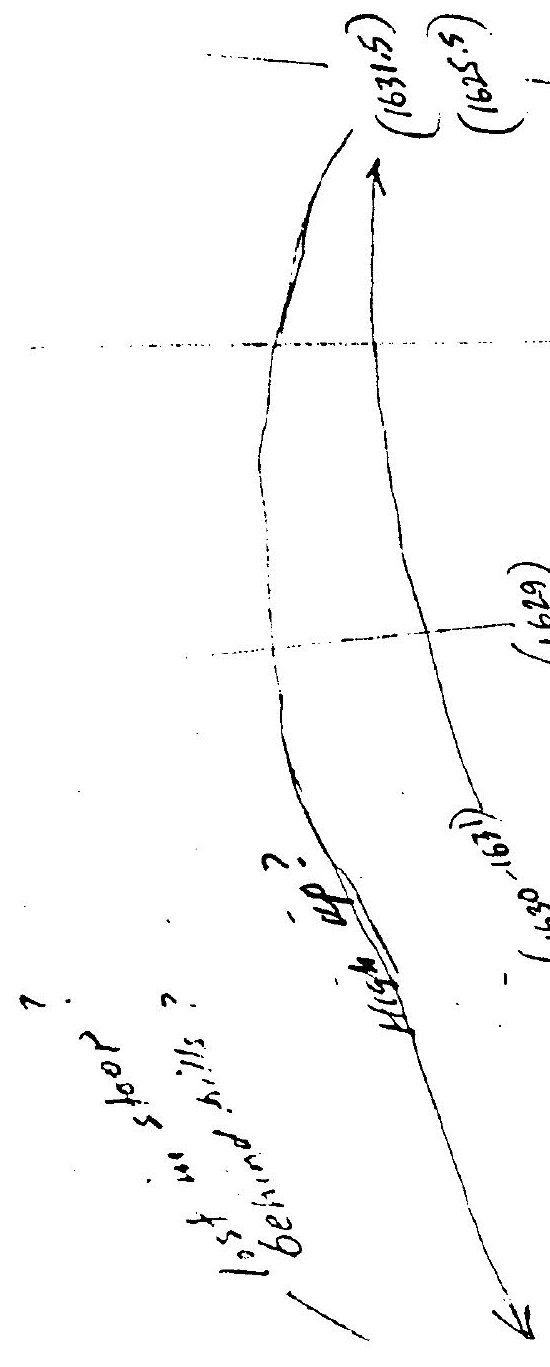
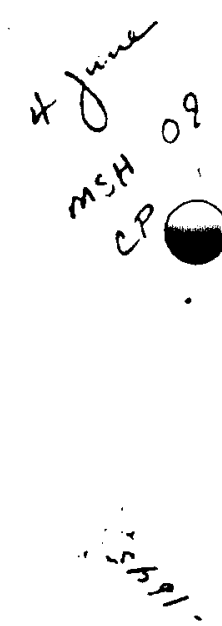

$\div$<smiles>[131IH]</smiles>

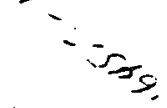

4 jum 


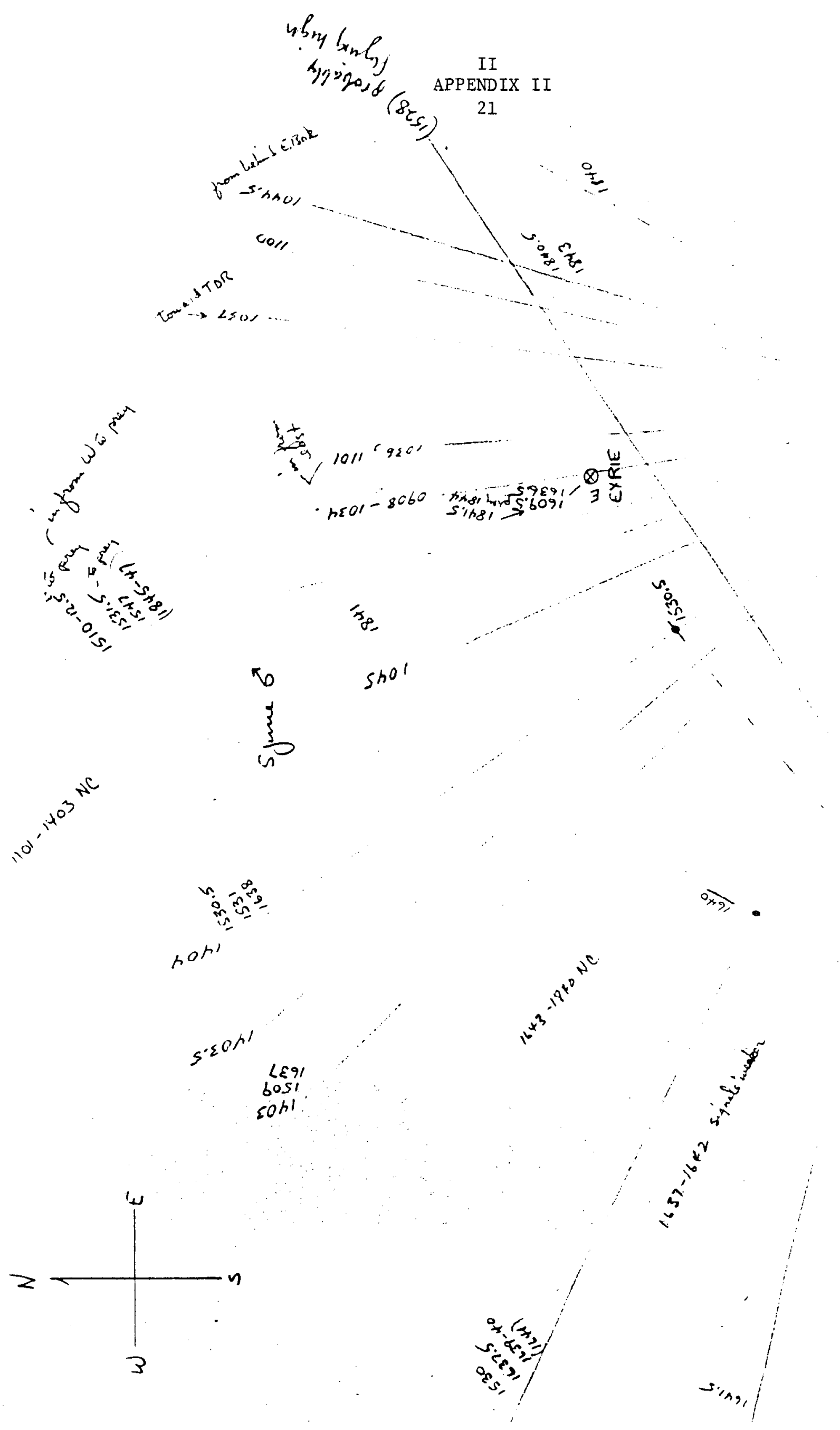


II

23

s.4 fuh yg ot
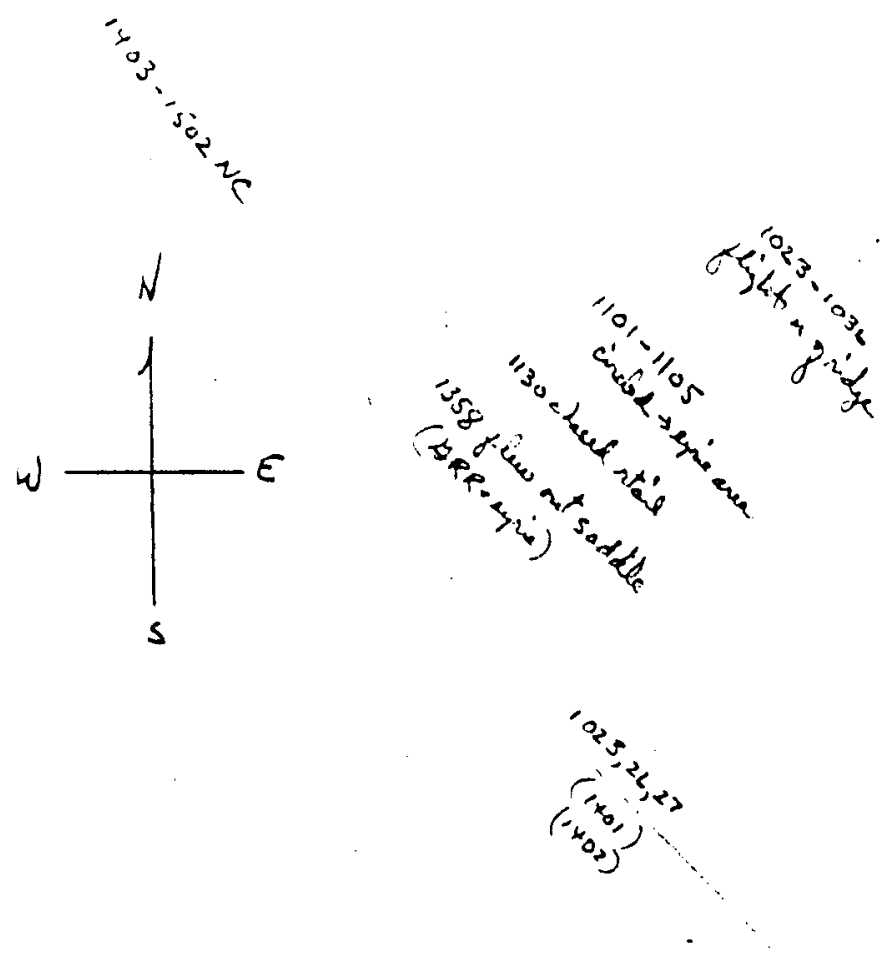

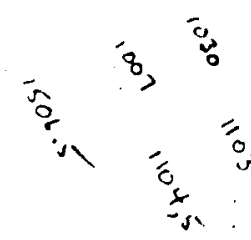

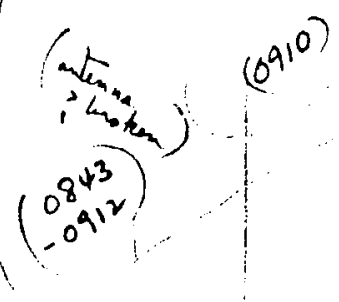

b) June ot
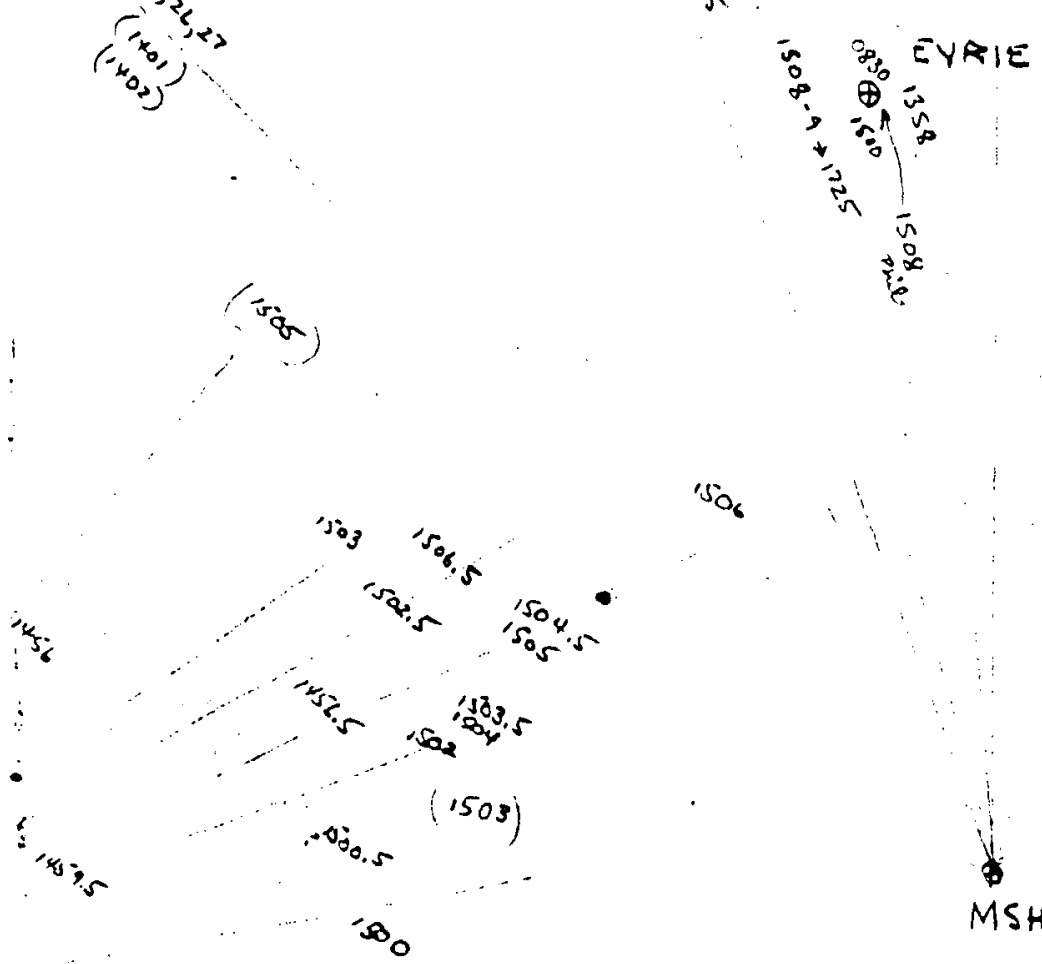

1506

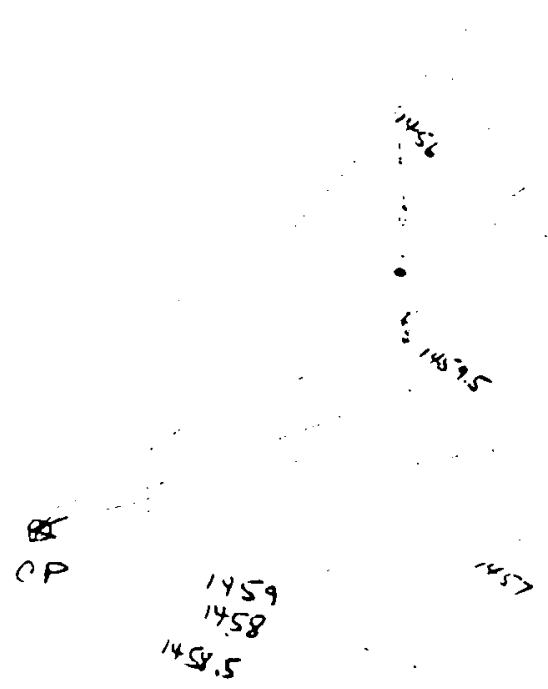




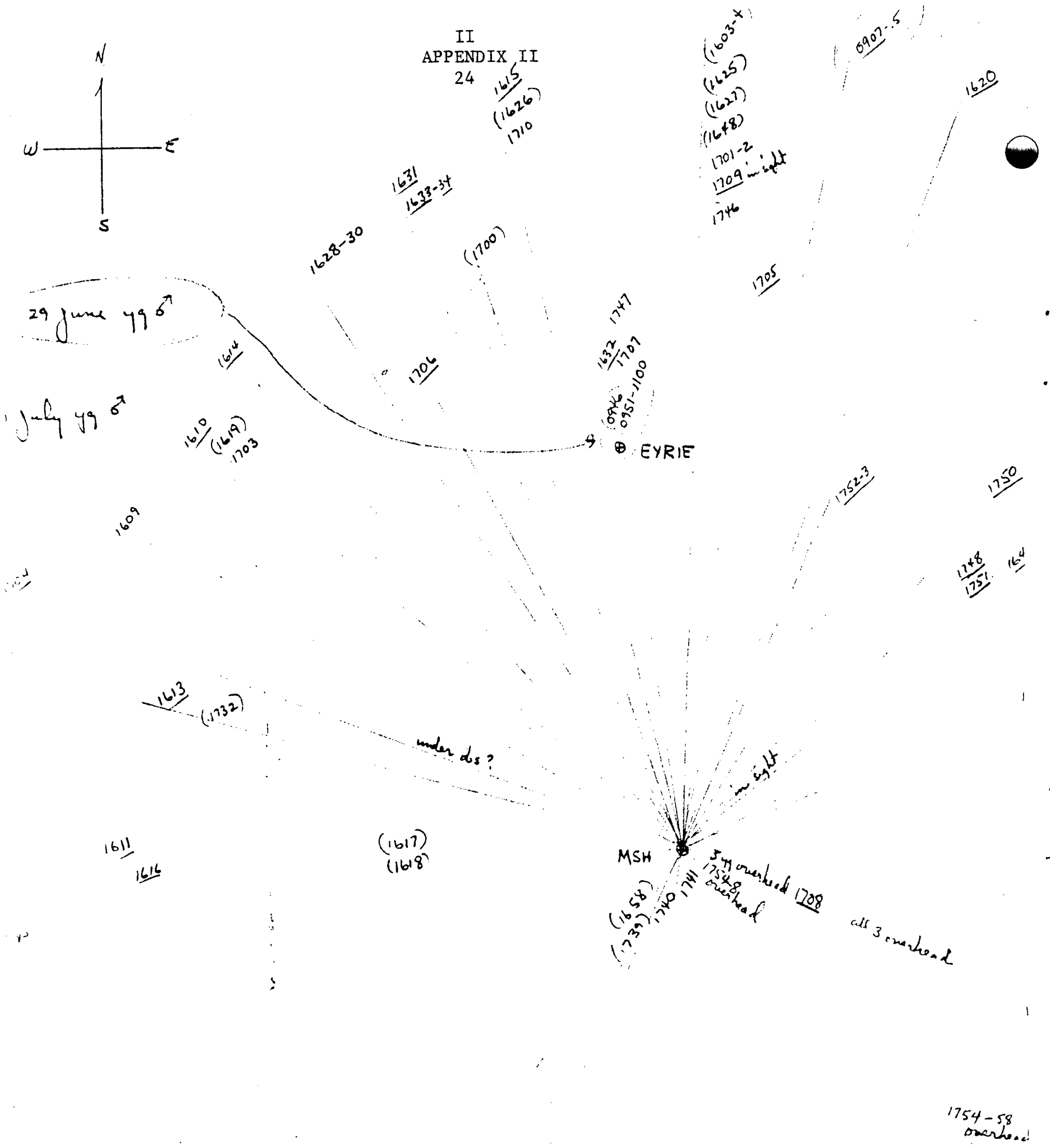


APPENDIX III

\section{PLOTTINGS OF ESTIMATED FLIGHT AREAS \\ OF RADIO-TAGGED PEREGRINES}

Shown are generalized flight routes by date for the adult female (27 April-31 May), adult male (3 June-6 June) and one young male ( 1 July) made from overlays of the Mount St. Helena 7.5 minute quadrangle sheet. Routes incorporate data from tracking bearings (Appendix II) and observer sightings and indicate regions of flight. Numbers on routes indicate time of observation.

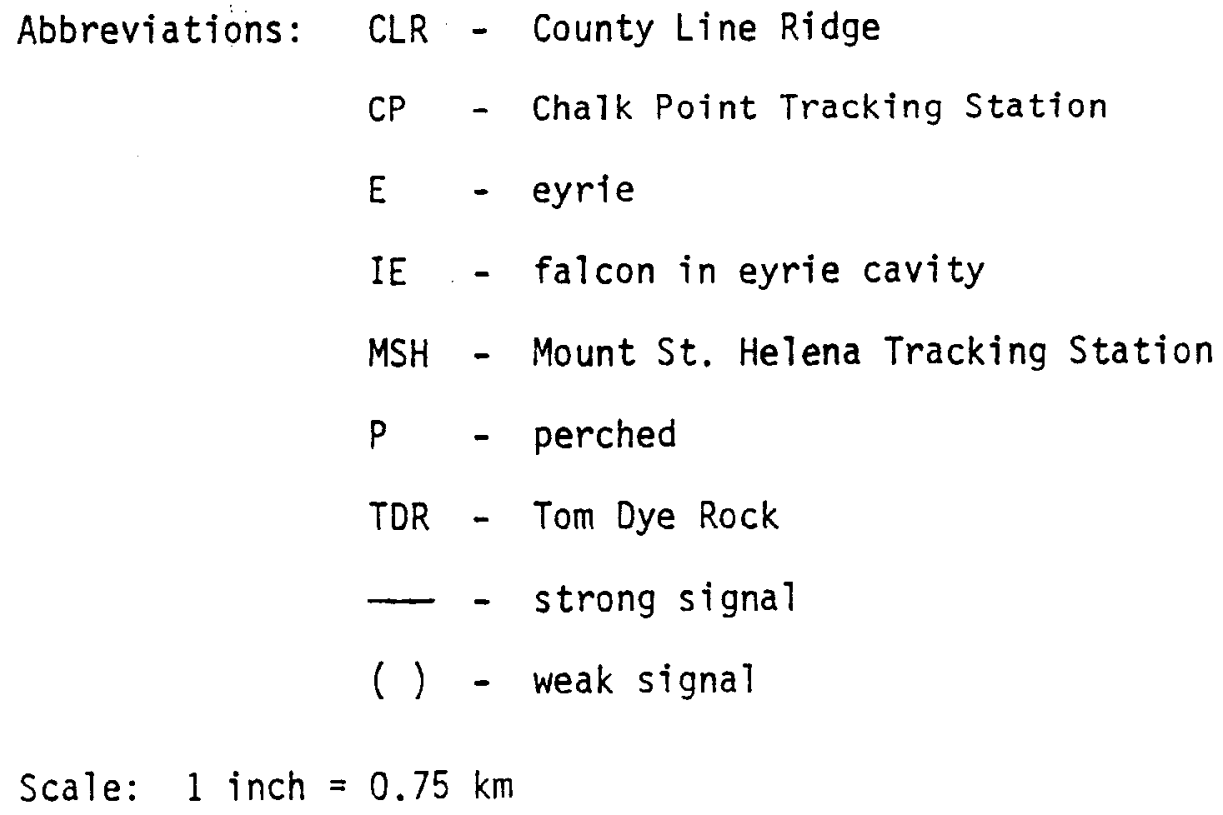



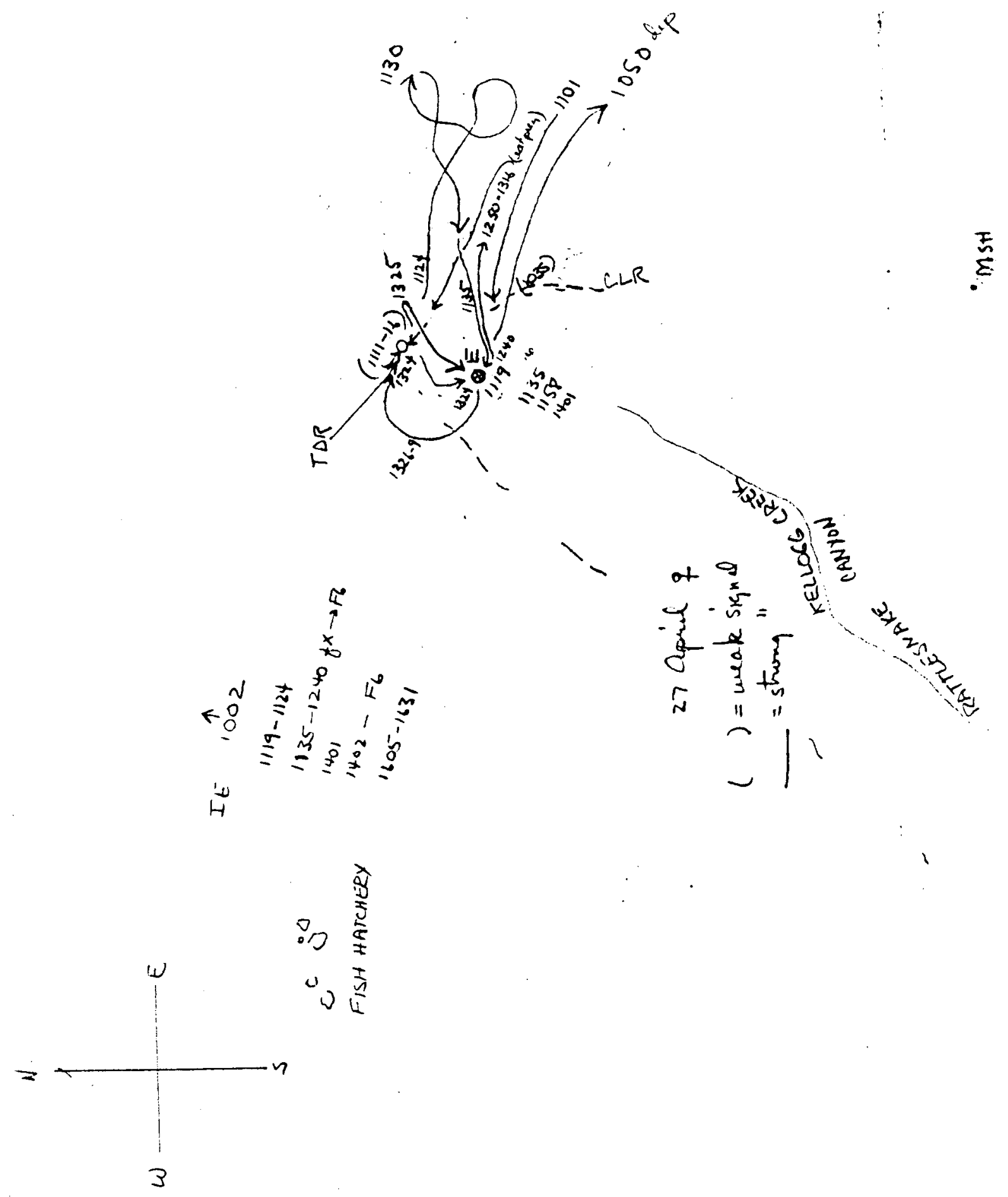

5 


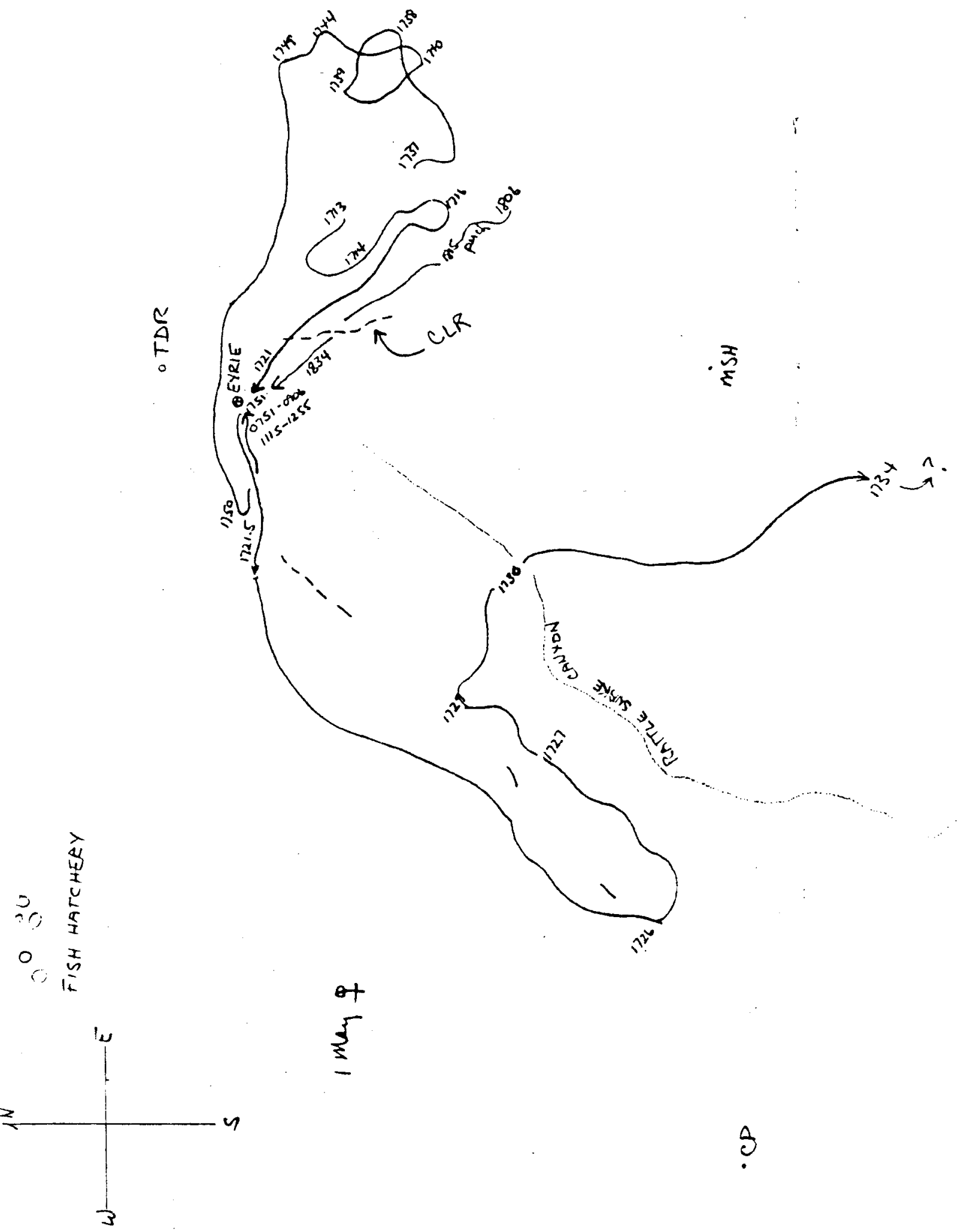




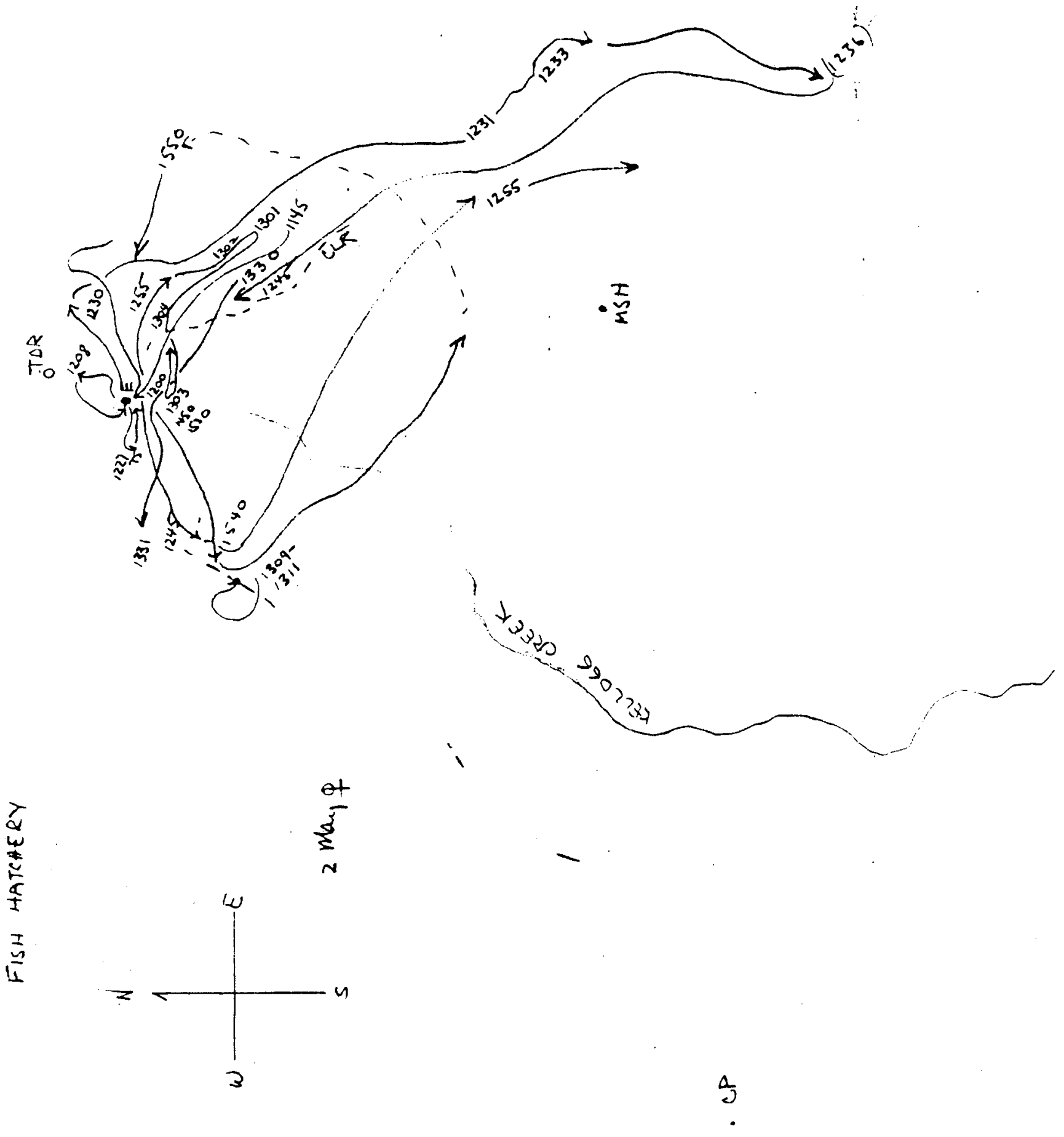



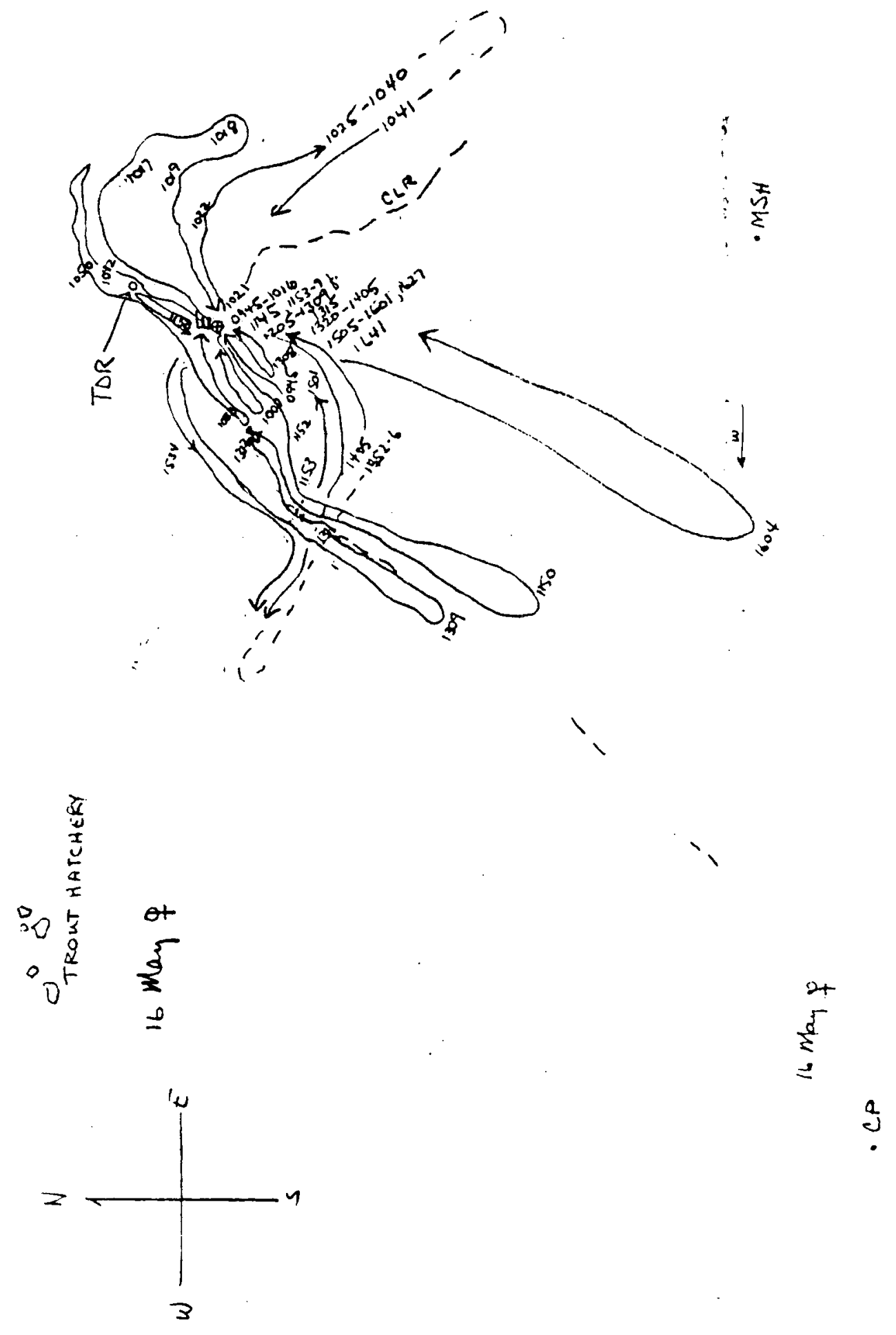


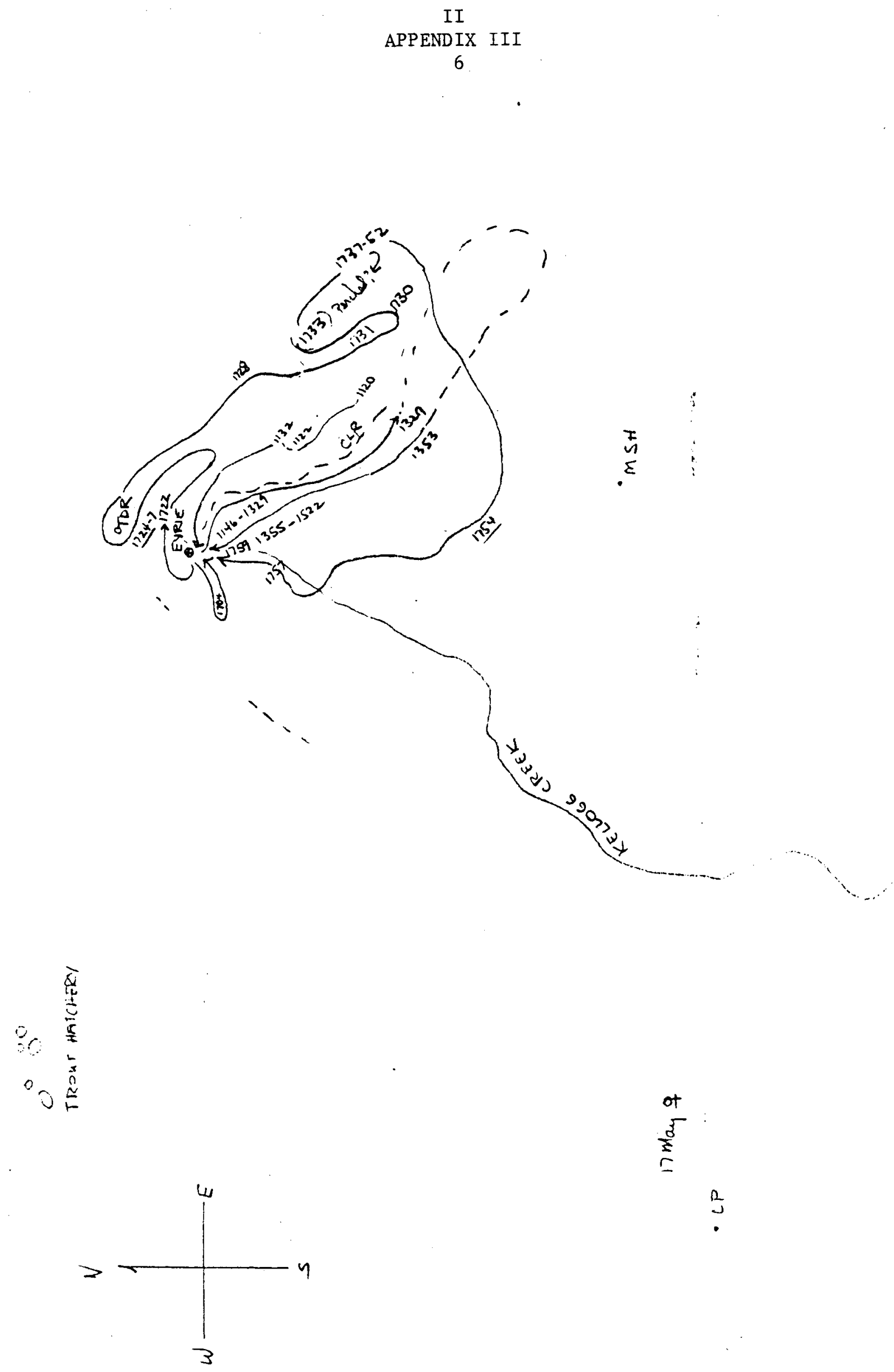




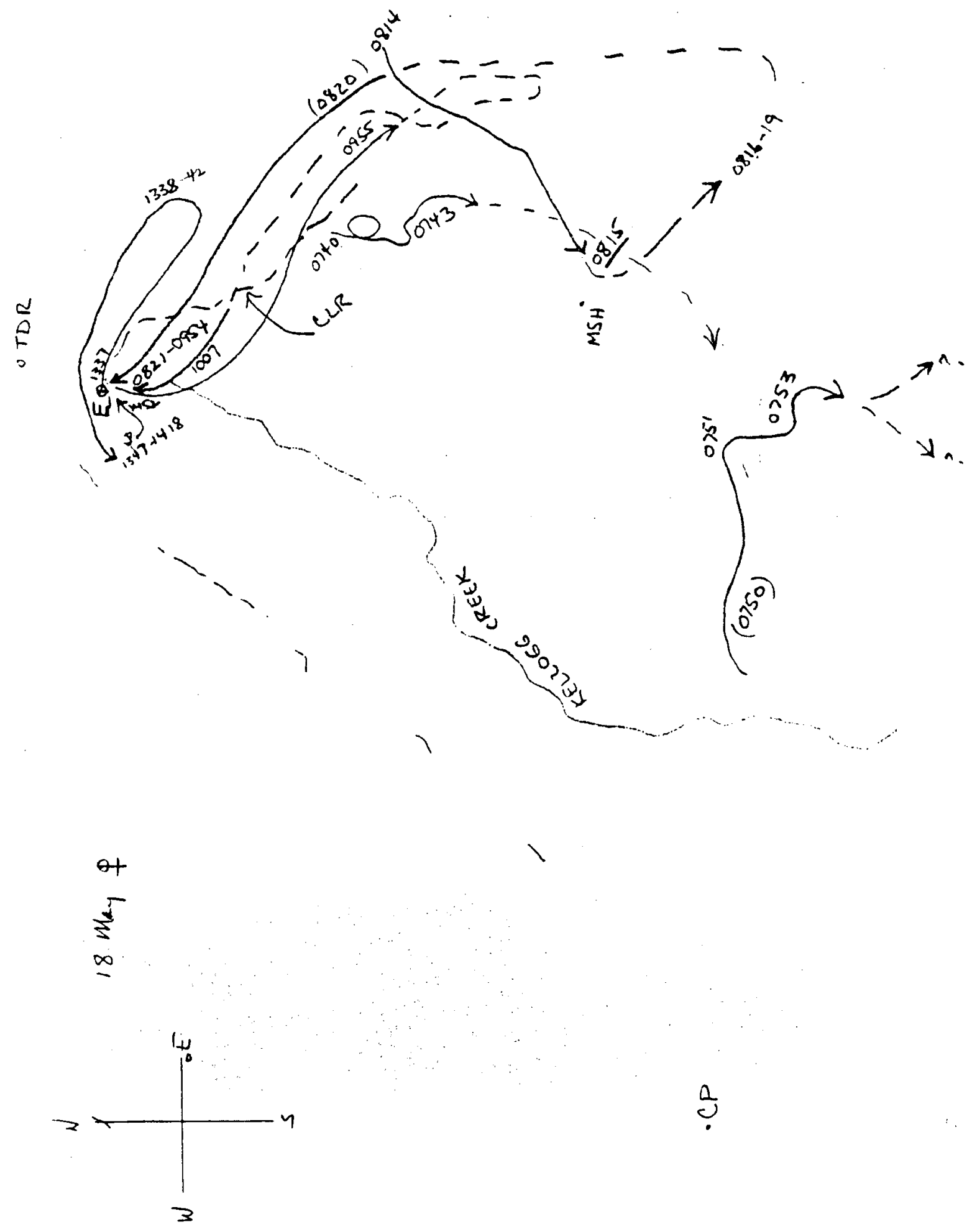



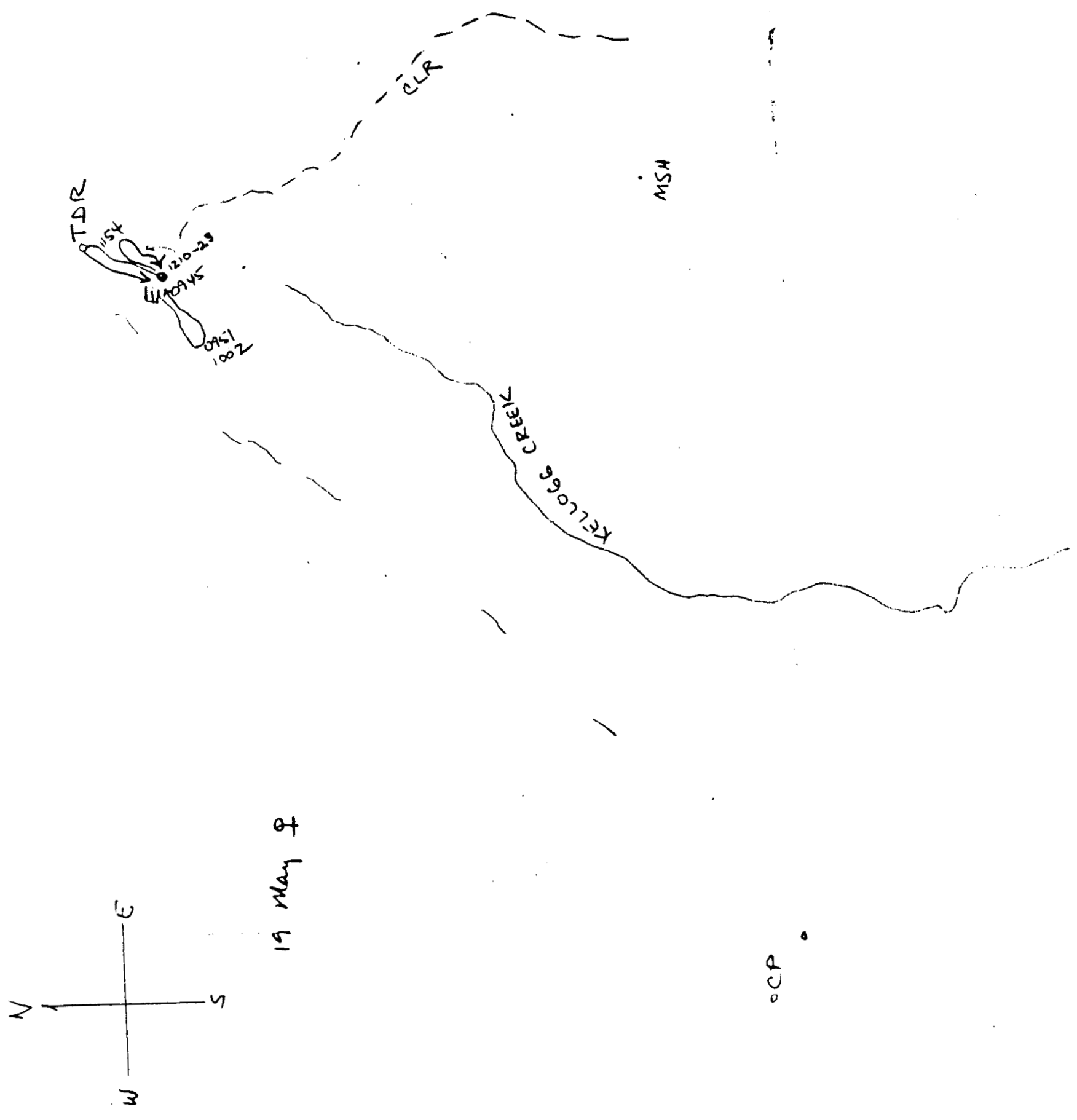


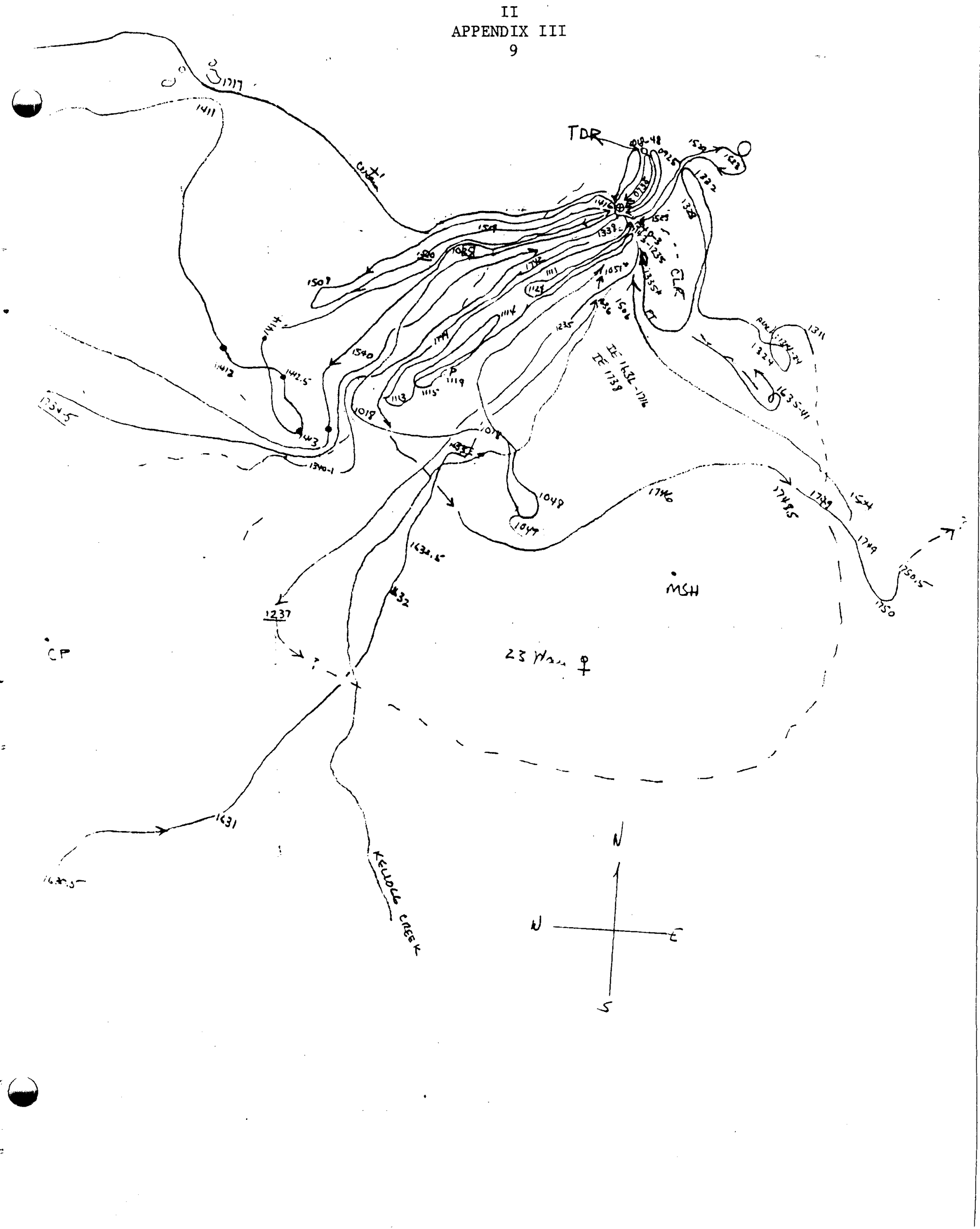




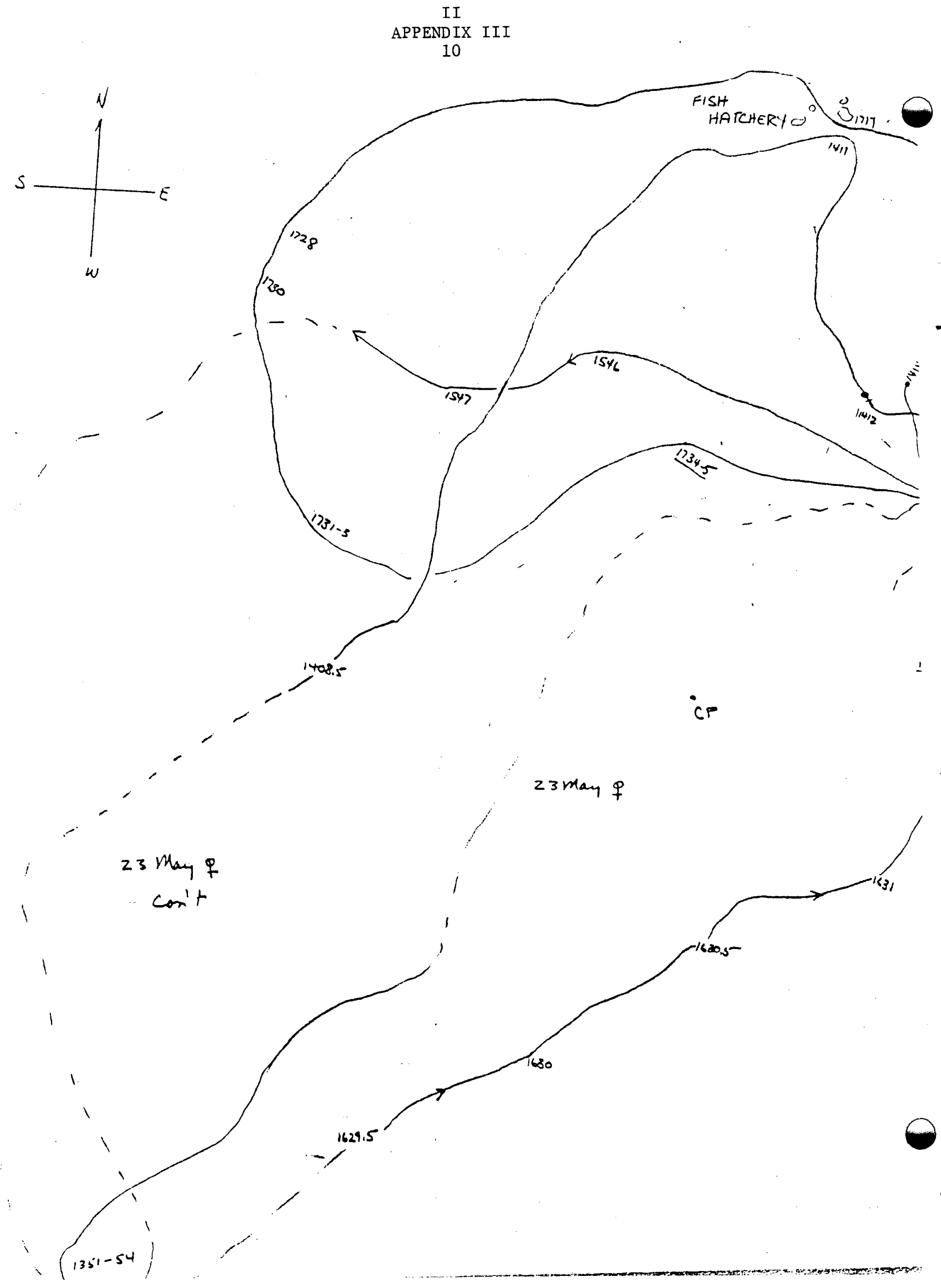



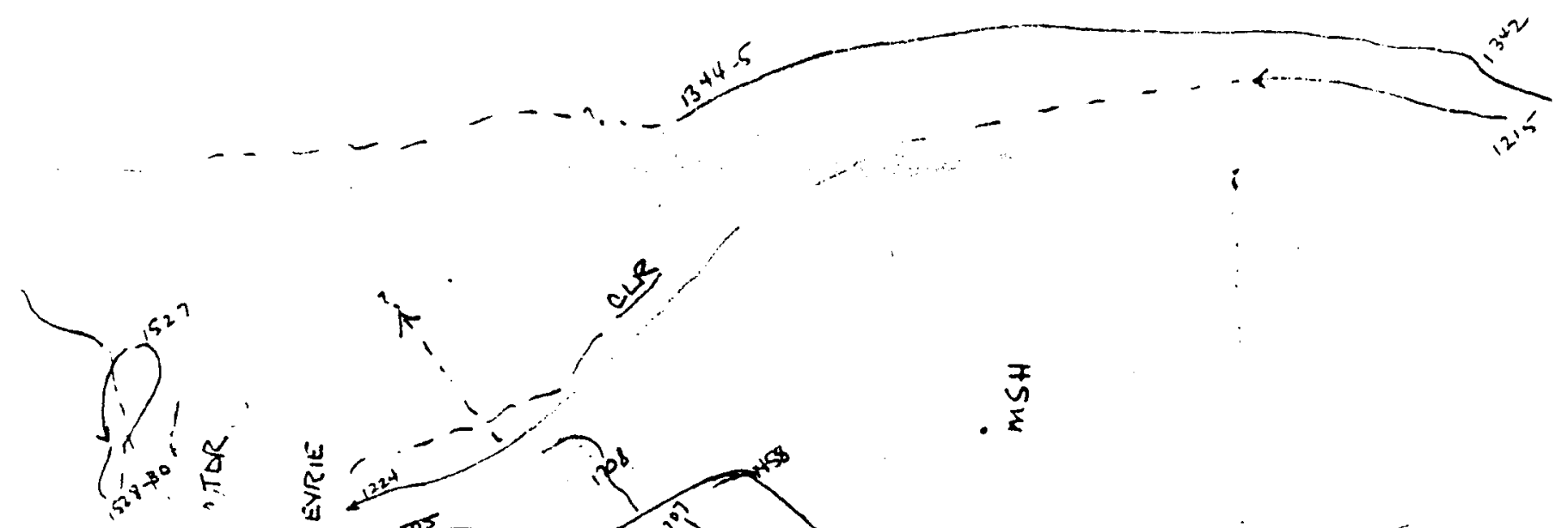

.

空
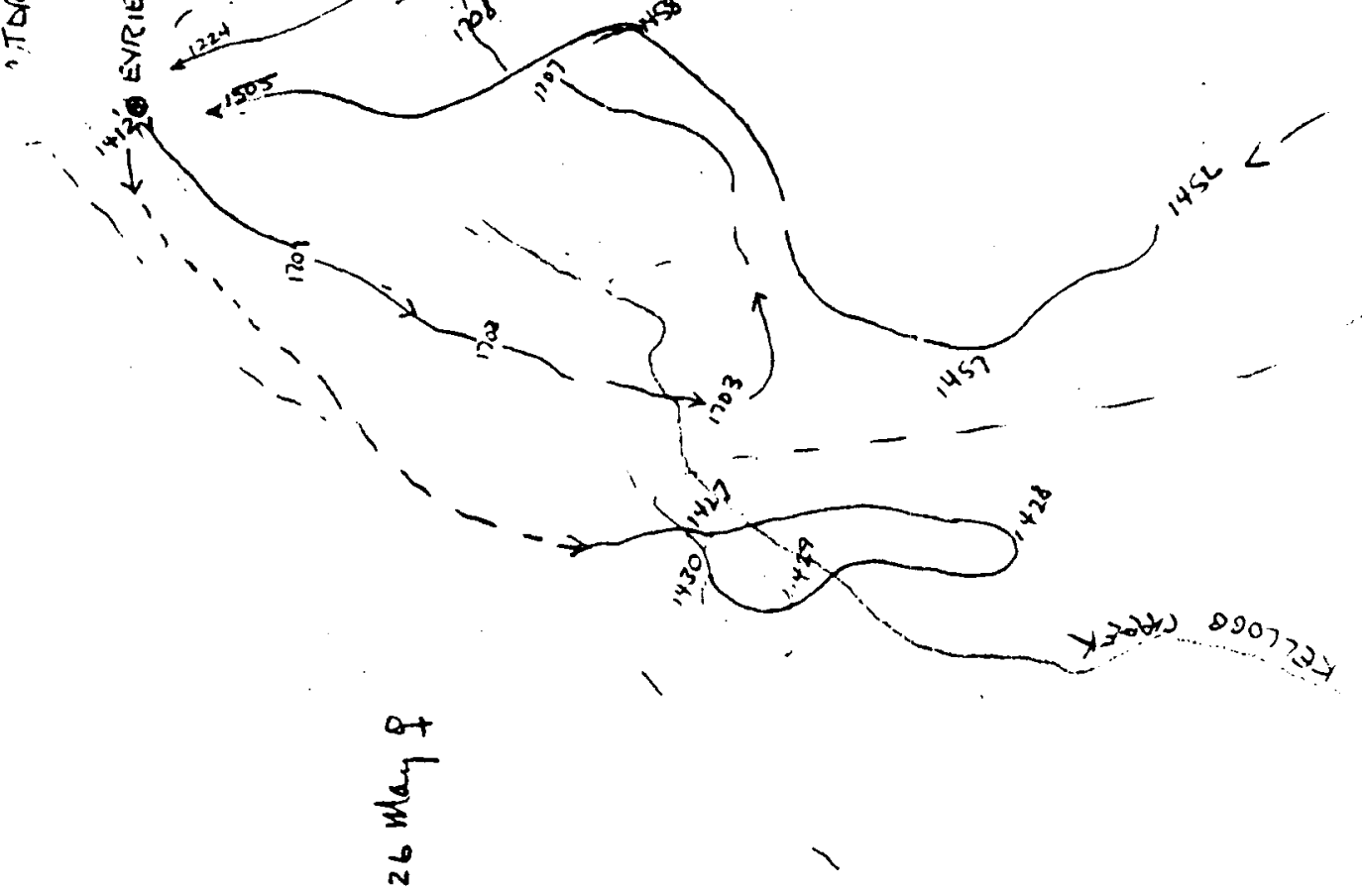

ฟี

$\frac{5}{2}$

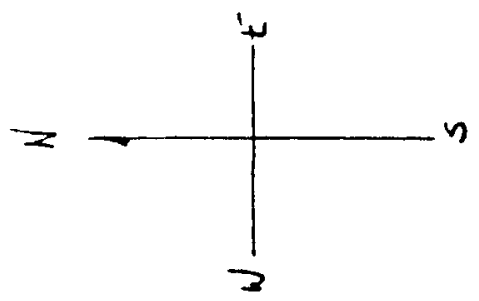

j 

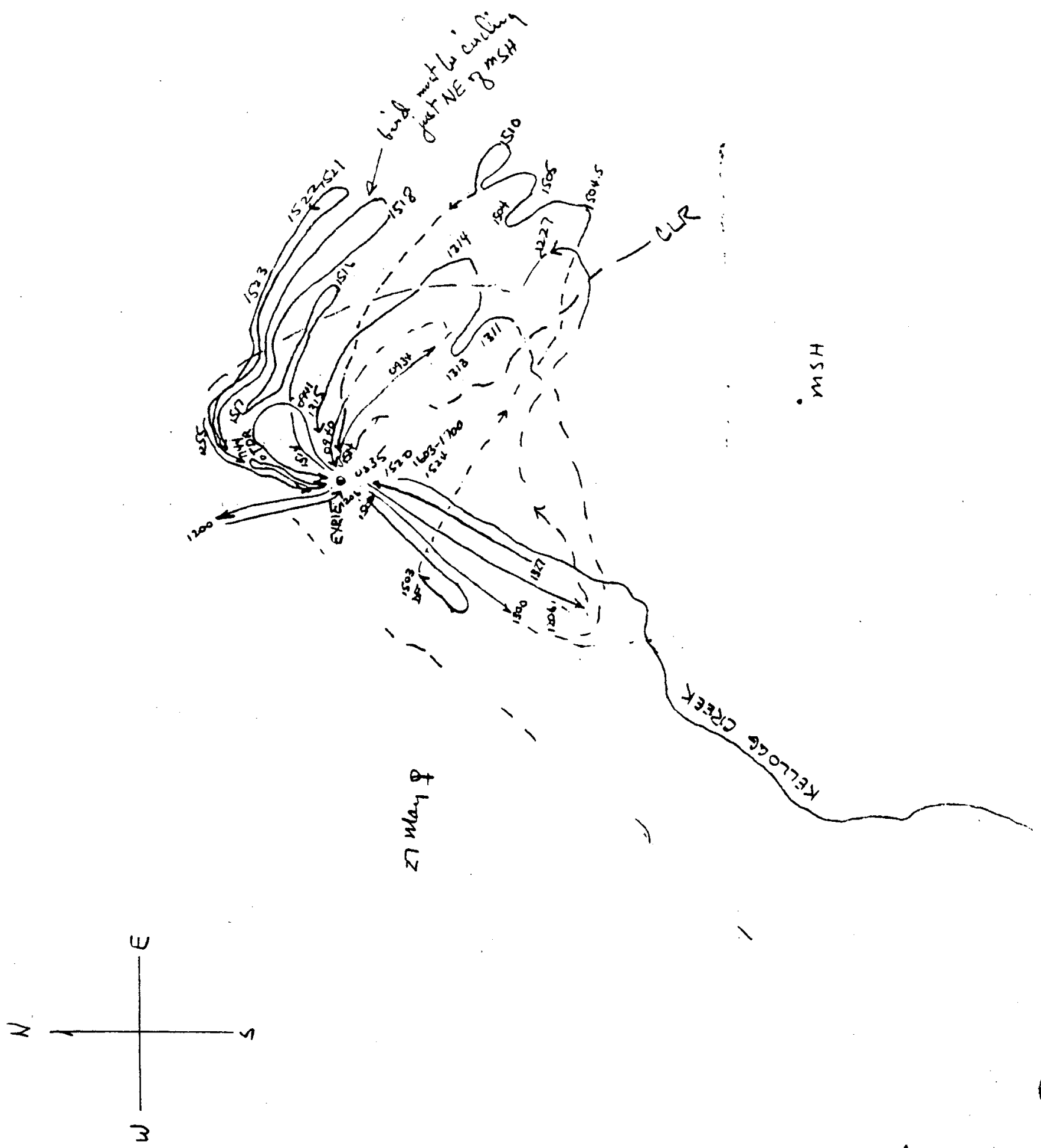


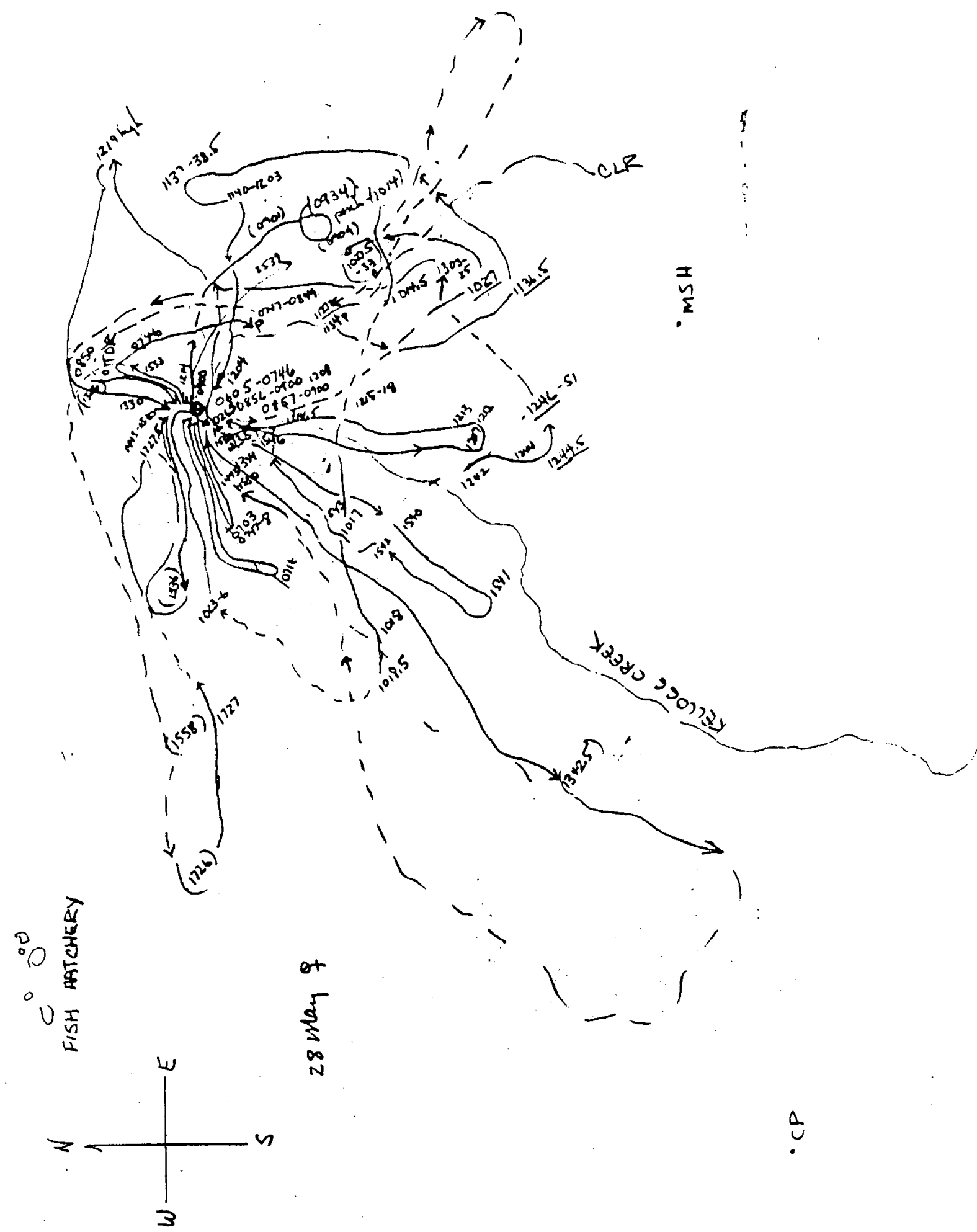


II

APPENDIX III

14

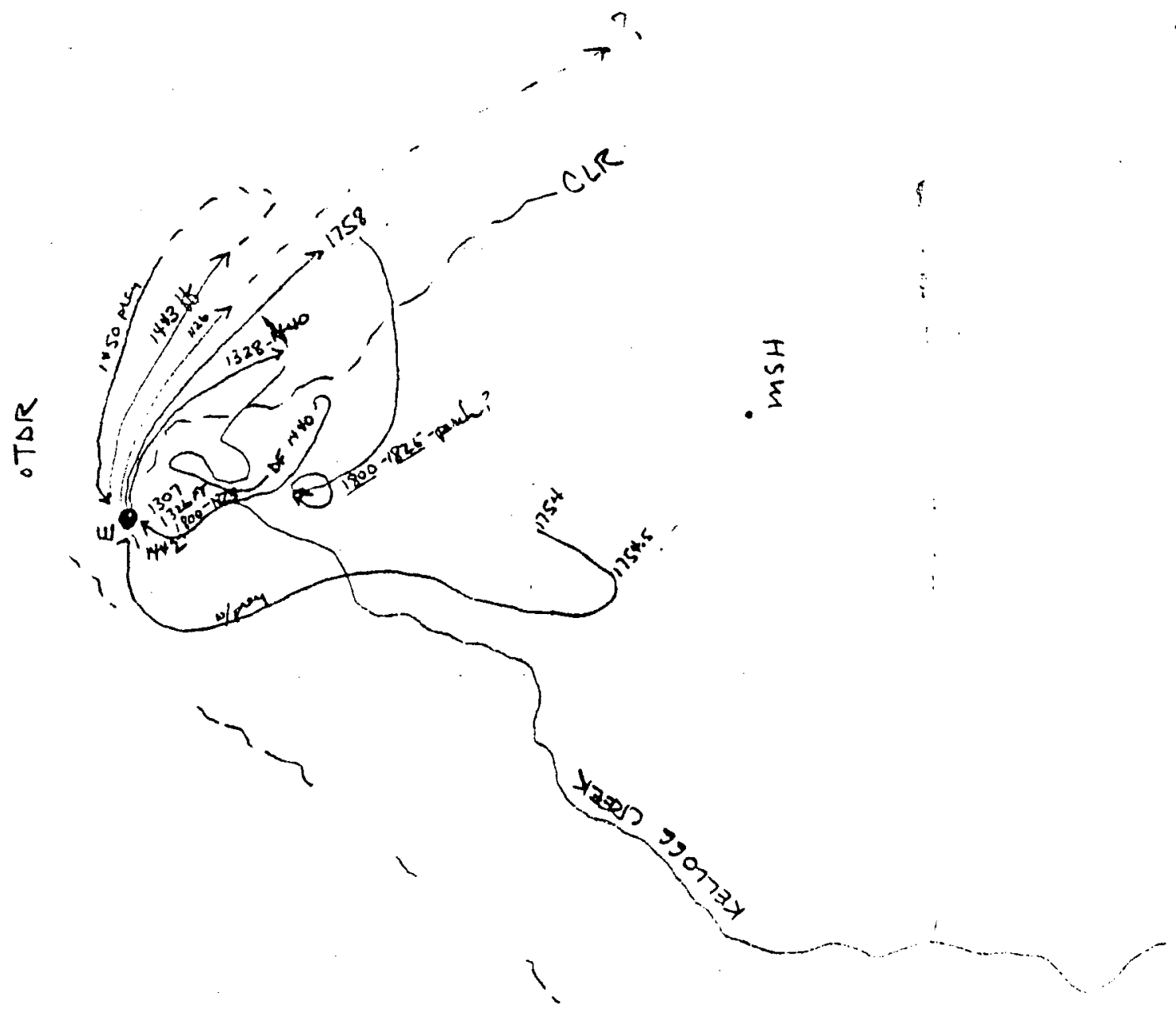

$\frac{\pi}{2}$

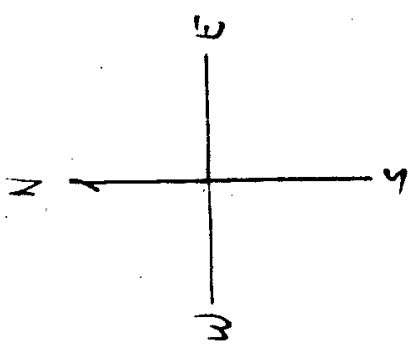

$a$ 

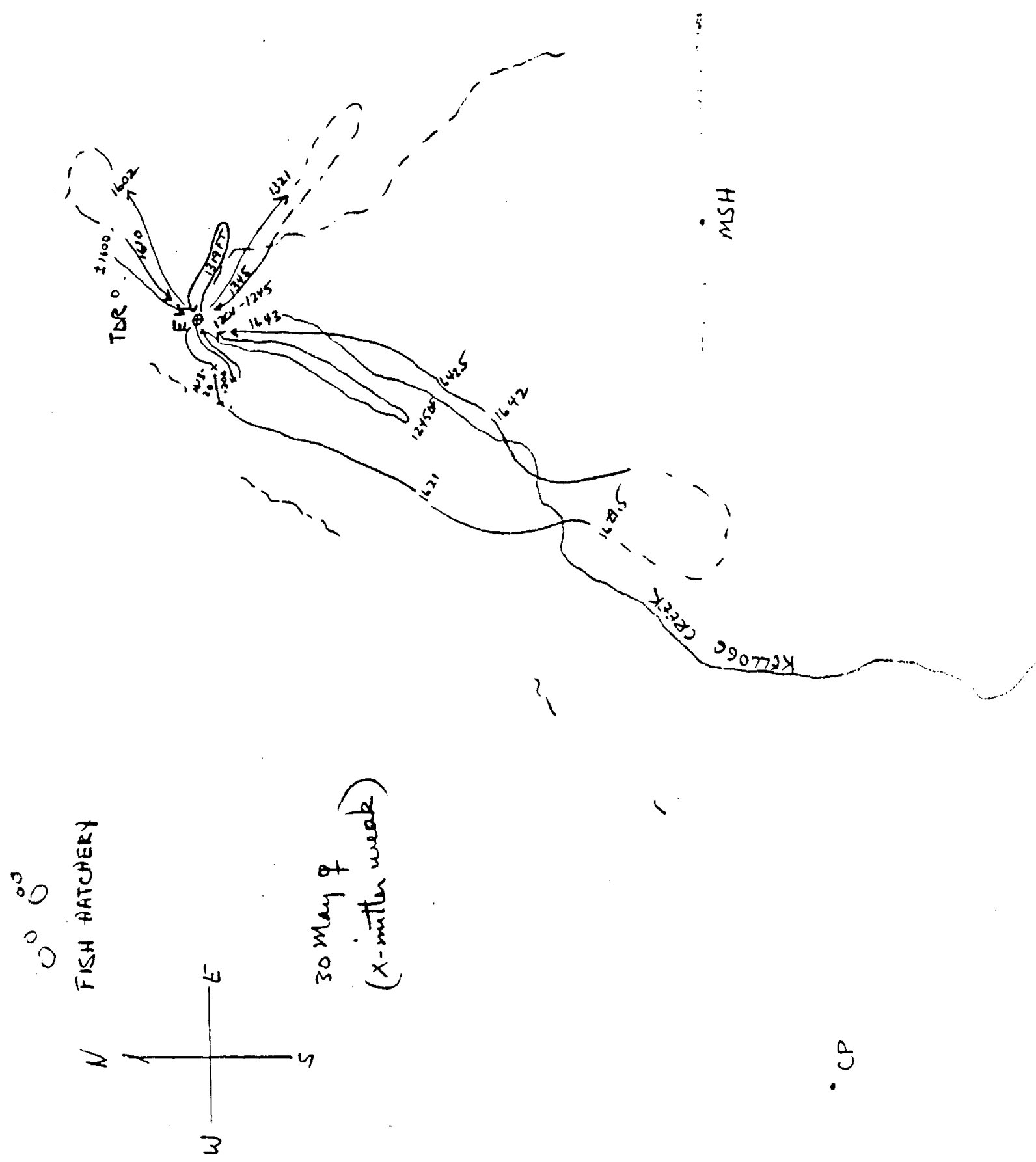

3 


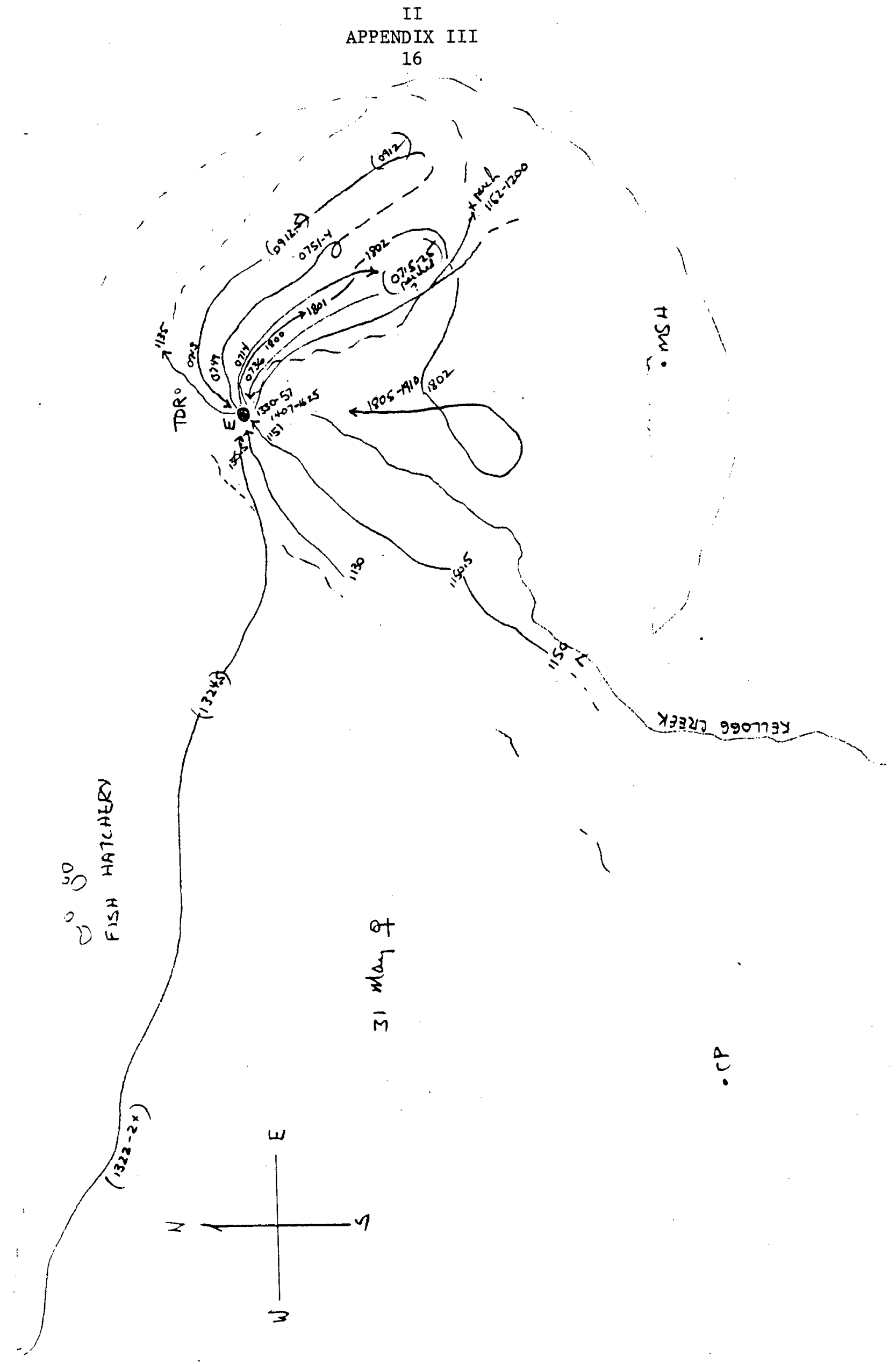




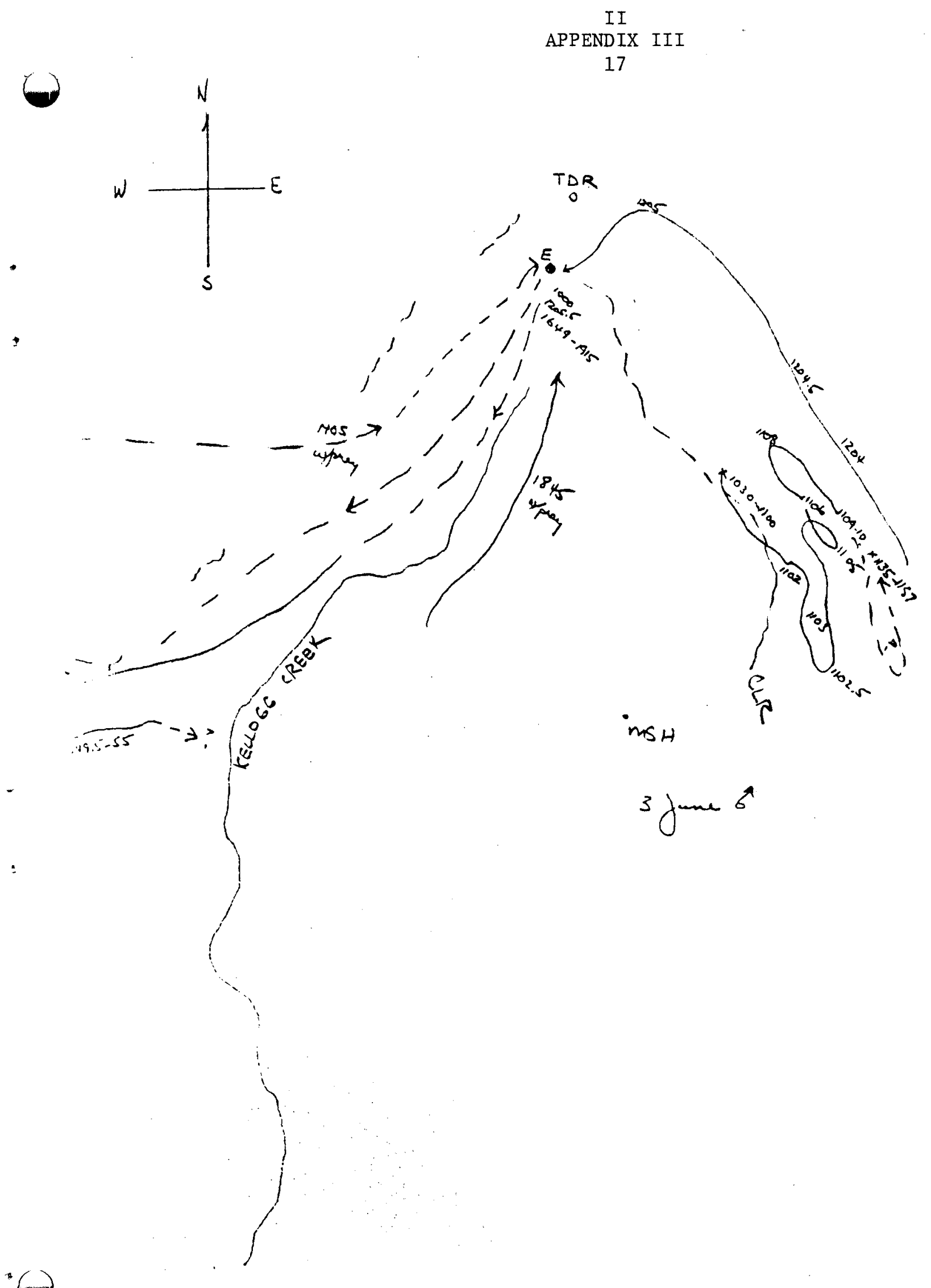




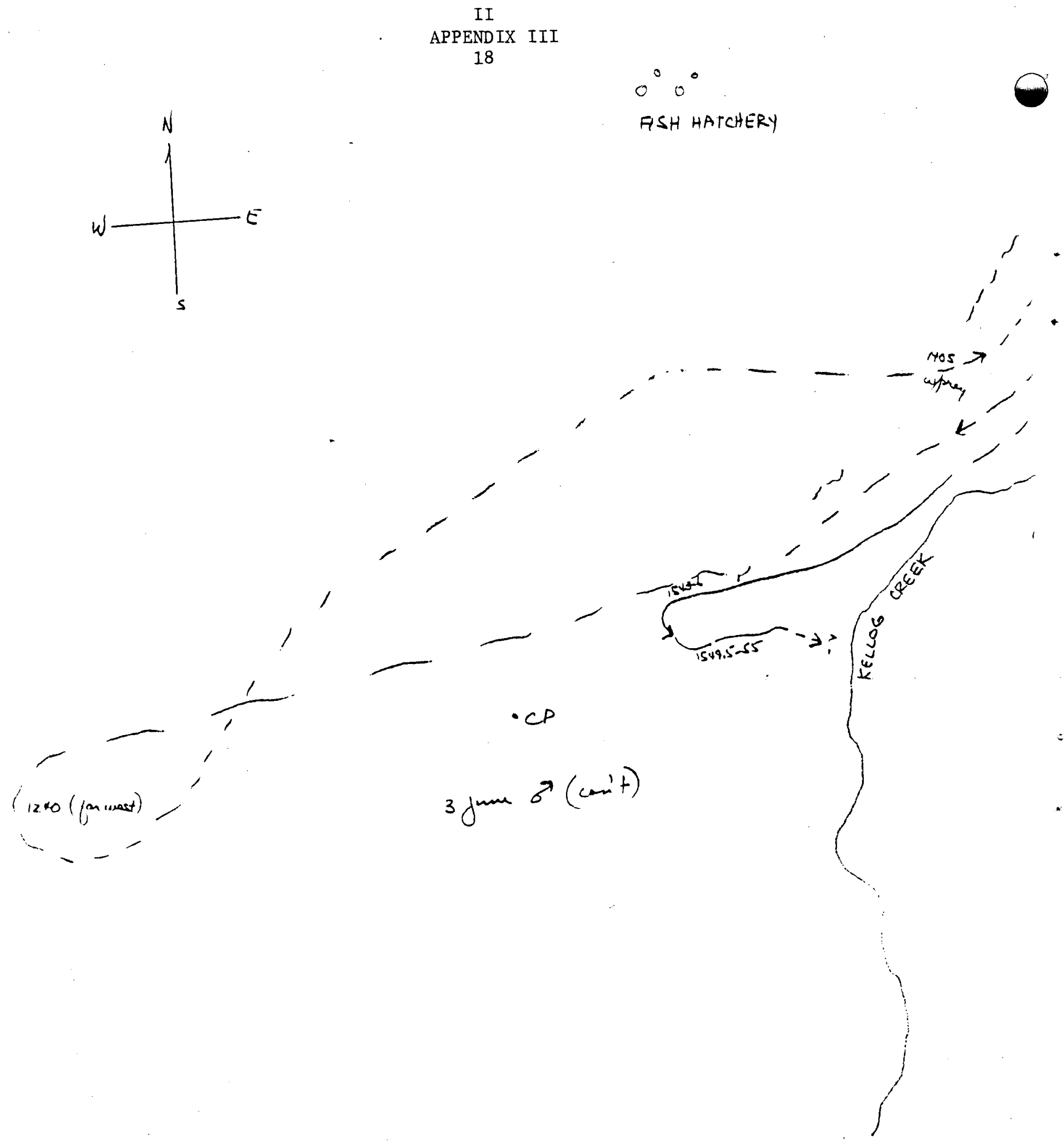




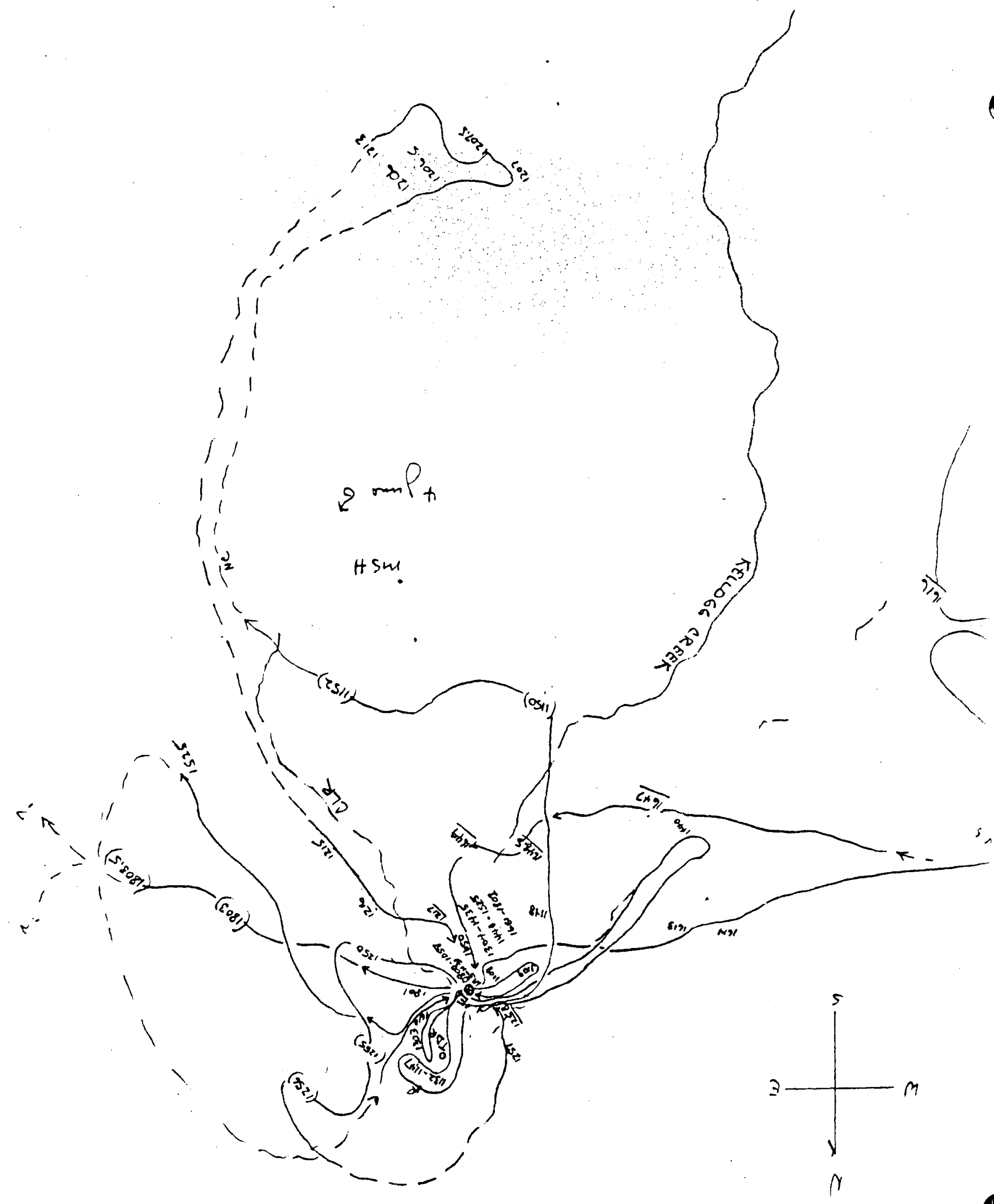


II
APPENDIX III
20

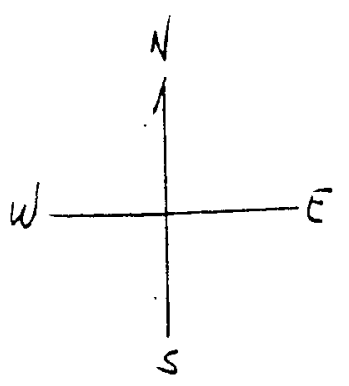

$$
\begin{aligned}
& 0^{\circ} 0^{\circ} \\
& \text { FISH HATCHERY }
\end{aligned}
$$

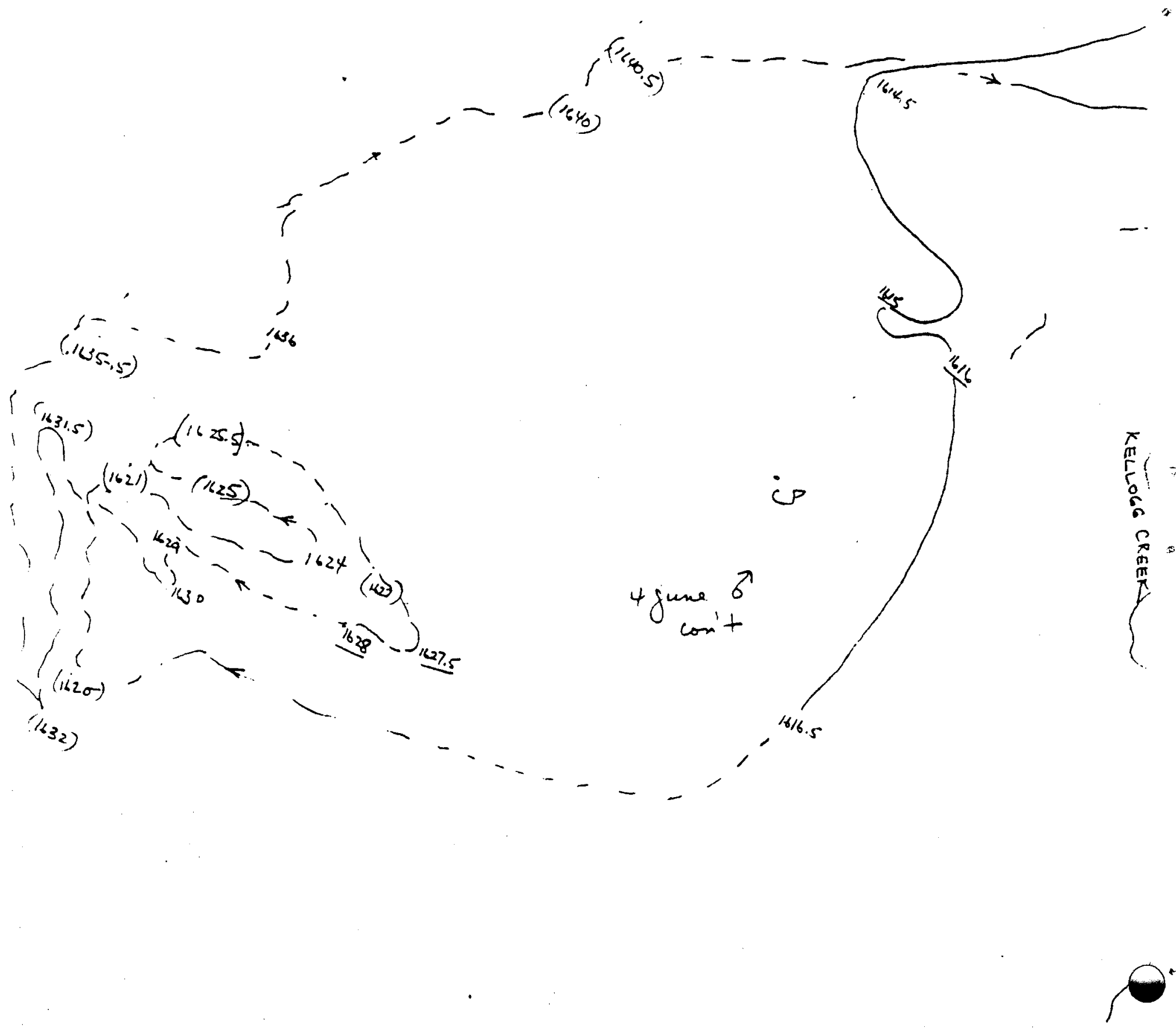


(2) $\quad N \quad E^{\circ}$

w)

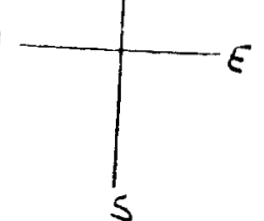

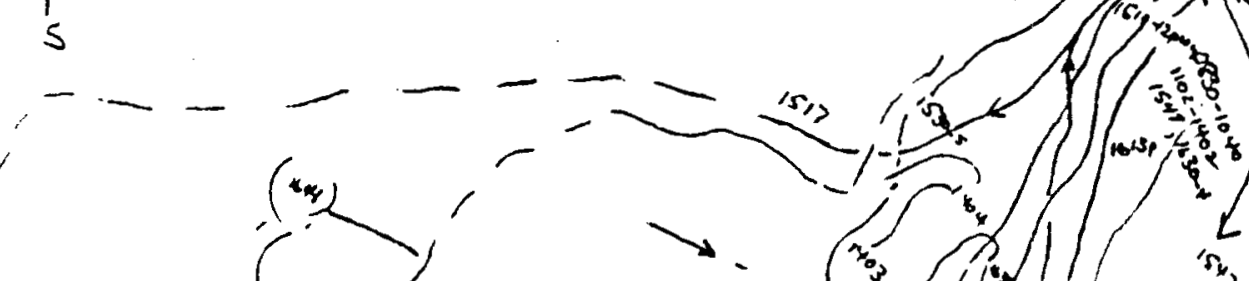
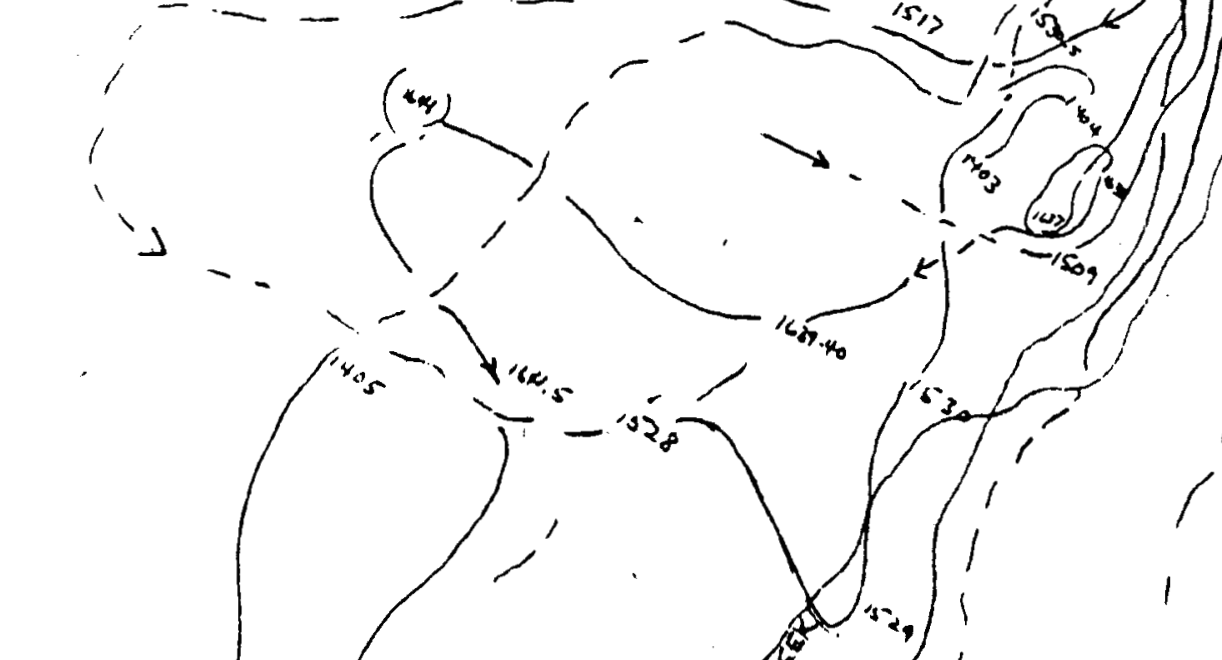

$(25)$

55.5<smiles></smiles>

$s_{2}$
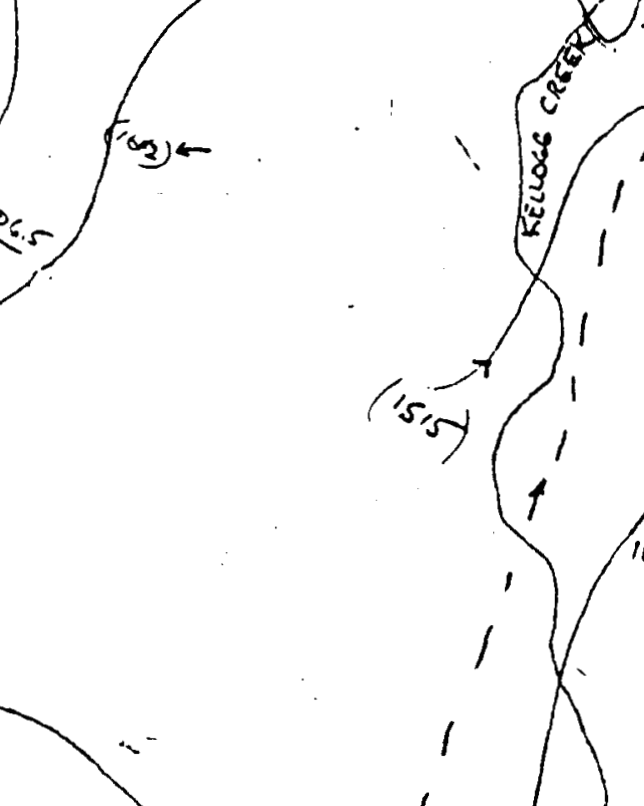


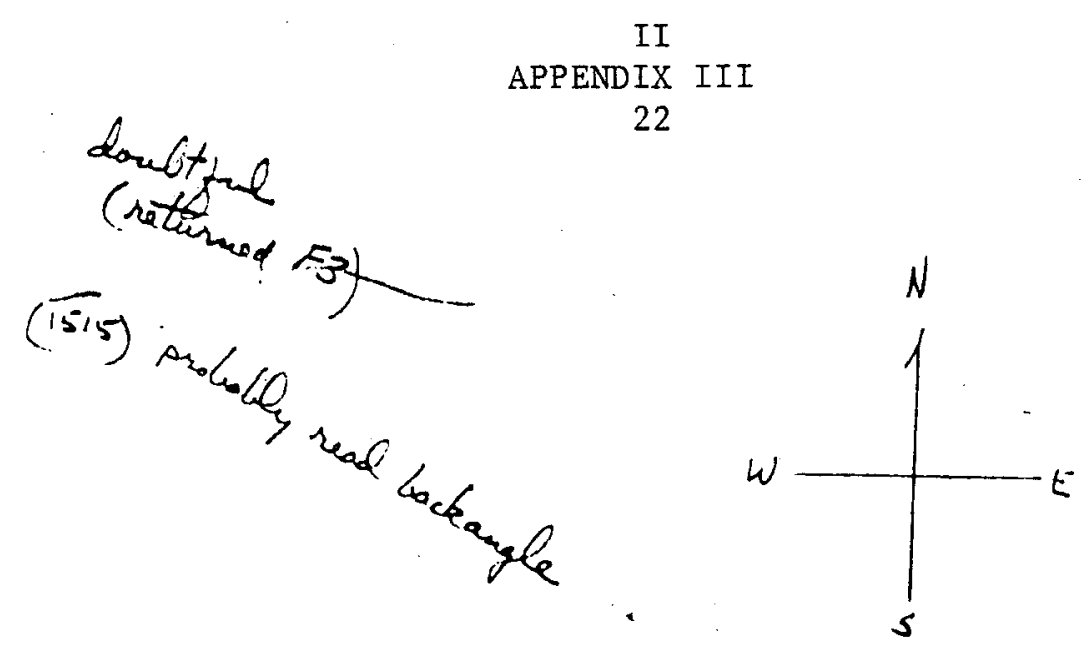




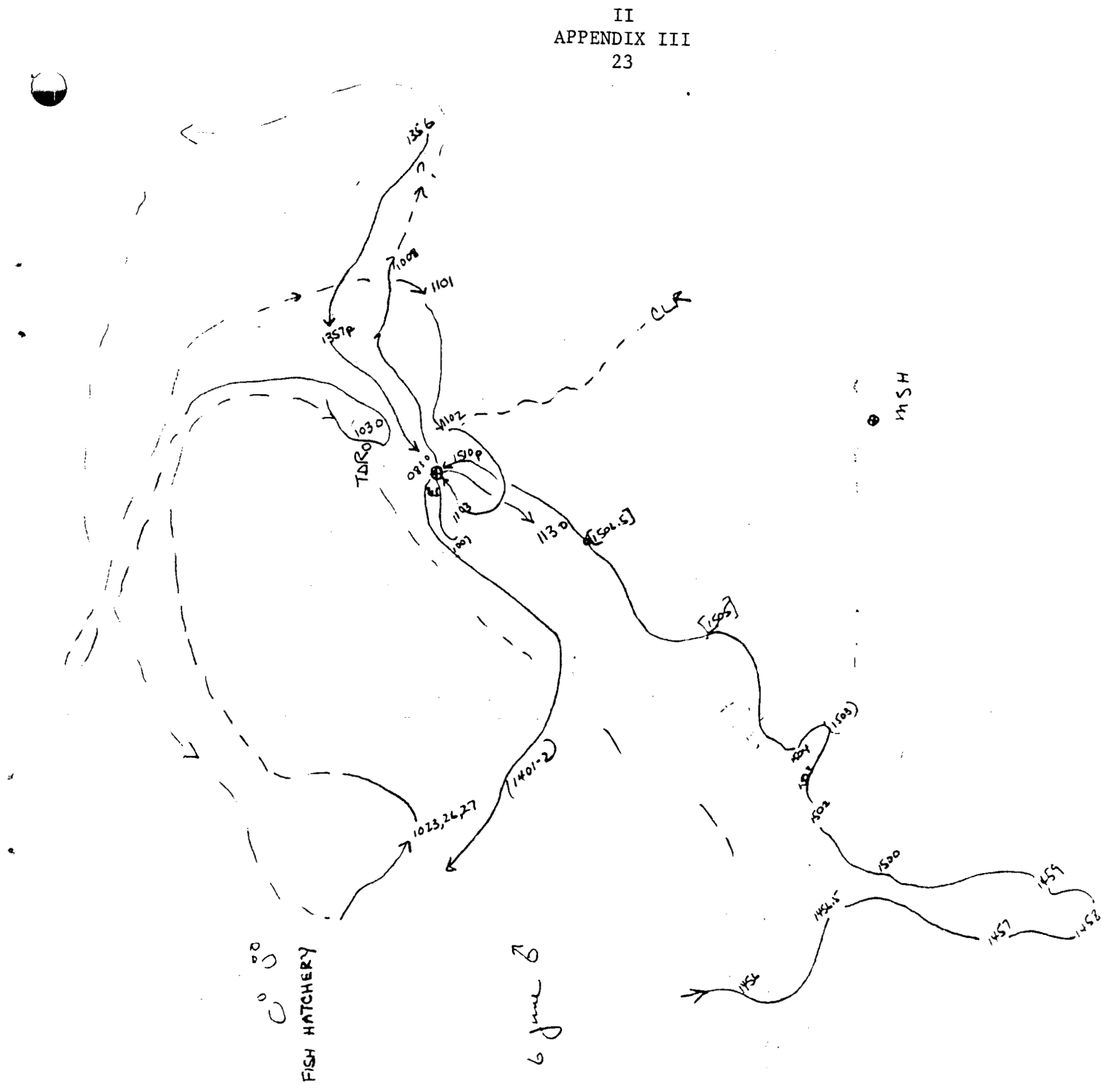

$\varepsilon^{4}$ 

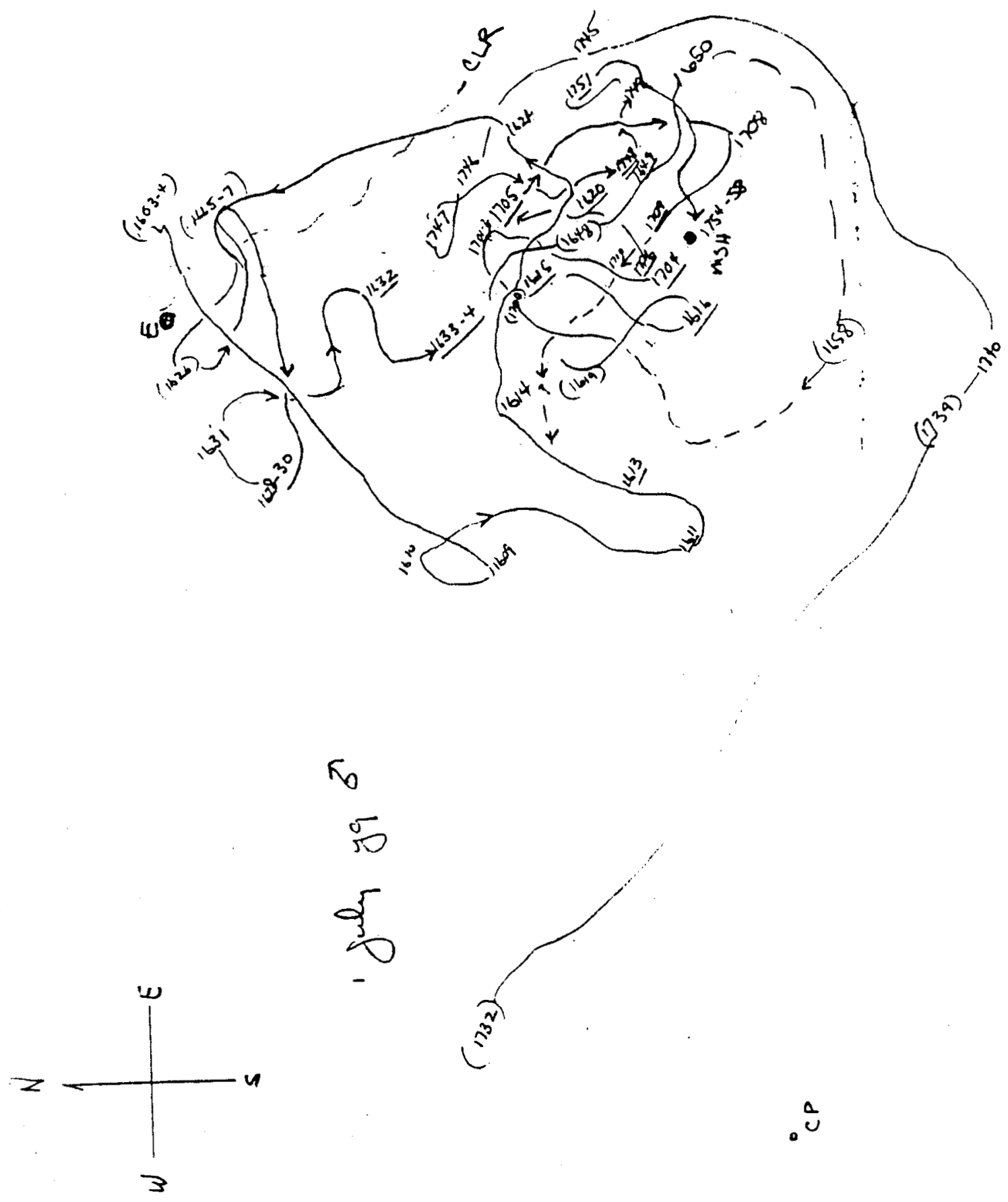

.0 